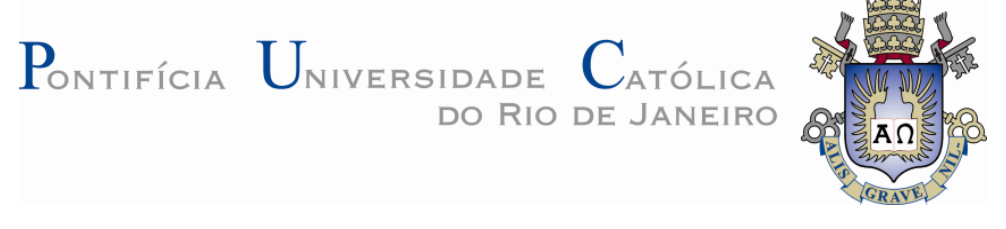

Erick Meira de Oliveira

\title{
Corporate Social Responsibility and Firm Performance: a case study from the Brazilian Electric Sector
}

Thesis presented to the Programa de Pós-Graduação em Engenharia de Produção of the Departamento de Engenharia Industrial, PUC-Rio as partial fulfillment of the requirements for the degree of Mestre em Engenharia de Produção.

Advisor: Prof. Carlos Patricio Samanez

Co-advisor: Prof. Marcelo Alvaro da Silva Macedo

Rio de Janeiro

April 2015 


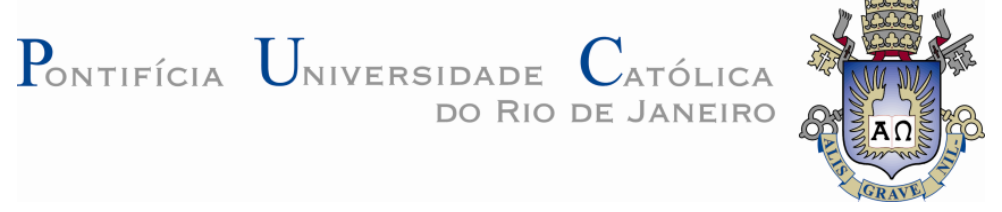

Erick Meira de Oliveira

\section{Corporate Social Responsibility and Firm Performance: a case study from the Brazilian Electric Sector}

Thesis presented to the Programa de Pós-Graduação em Engenharia de Produção of the Departamento de Engenharia Industrial do Centro Técnico Científico da PUC-Rio, as partial fulfilment of the requirements for the degree of Mestre.

Prof. Carlos Patricio Samanez

Advisor

Departamento de Engenharia Industrial - PUC-Rio

Prof. Marcelo Alvaro da Silva Macedo

Co-advisor

Faculdade de Administração e Ciências Contábeis - UFRJ

Prof. Fernando Luiz Cyrino Oliveira

Departamento de Engenharia Industrial - PUC-Rio

Prof. Antonio Carlos Gonçalves

Departamento de Matemática - UFRRJ

Prof. José Eugênio Leal

Coordinator of the Centro Técnico Científico da PUC-Rio

Rio de Janeiro, April1st, 2015 
All rights reserved.

\section{Erick Meira de Oliveira}

Erick Meira graduated cum laude from the Federal University of Rio de Janeiro with a B. Eng. in Oil and Gas Engineering in 2012, having also participated in a sixmonth academic programme at École Nationale Supérieure des Mines d'Alès (France). After college, he began working for the Brazilian Innovation Agency (Finep), analysing projects related to Energy and Green Technologies.

Bibliographic Data

Oliveira, Erick Meira de

Corporate Social Responsibility and Firm Performance: a case study from the Brazilian Electric Sector / Erick Meira de Oliveira ; advisor: Carlos Patricio Samanez ; co-advisor: Marcelo Alvaro da Silva Macedo. 2015.

172 f. : il. (color.) ; $30 \mathrm{~cm}$

Dissertação (Mestrado) - Pontifícia Universidade Católica do Rio de Janeiro, Rio de Janeiro, 2015.

Inclui bibliografia

1. Engenharia Industrial - Teses. 2. Responsabilidade Social Empresarial. 3. Análise de Performance Financeira. 4. Setor Elétrico Brasileiro. 5. Análise Envoltória de Dados. 6. Investimentos socioambientalmente responsáveis. I. Samanez, Carlos Patricio. II. Macedo, Marcelo Alvaro da Silva. III. Pontifícia Universidade Católica do Rio de Janeiro. Departamento de Engenharia Industrial. IV. Título.

CDD: 658.5 


\section{Acknowledgements}

First and foremost, I would like to thank Almighty God for giving me the wisdom, strength, and power to persevere throughout this journey. Without His blessings, none of this would be possible.

I am eternally grateful to my family for their undying support and unconditional love. Thank you for believing in me.

I feel great pleasure in expressing my profound gratefulness, gratitude and venerable regards to my advisor, Professor Carlos Patricio Samanez, for his meticulous guidance, scientific supervision and constant encouragement during the progress of my research work. I am also deeply indebted to all my beloved teachers and non-teaching staffs for their co-operation and timely helps. I would also like to express my deepest appreciation to my co-advisor, professor Marcelo Alvaro da Silva Macedo, for his continuous guidance and valuable comments all over the research work.

There are also many colleagues that have been supportive and helpful during my master's period, and I am very grateful for that. There are some people that I would like to thank in particular: Maurício Sant'Anna, Raffael Capano, Douglas Sad, Ali Sharafi and Filipe Polis. I also appreciated the support of the university staff during the early stages of my Masters course. Particular thanks in this regard go to Claudia Guimarães Teti and Isabel Finoti.

My warm thanks go to Dr. André Assis de Salles, my undergraduate supervisor, who played an important role in my academic growth and development and encouraged me to apply for the Master's programme. I also look back on pleasant conversations with my university colleagues over the years: André Canavarros, Victor Costa, Heitor Hartmann and Eduardo Thimóteo.

Gratitude also goes to participants of: the 4th edition of the Latin America Energy Economics Meeting, held in Montevideo (UY); the 45th and 46th editions of Brazilian Symposium on Operations Research (XLV and XLVI SBPO), held in Natal, Rio Grande do Norte and Salvador, Bahia (BR); the 18th edition of the Latin American Summer Workshop on Operations Research (XVIII ELAVIO 
2014), which took place in Areia, Paraíba (BR); and the 2nd Economics of LowCarbon Markets Conference (2nd LCM), held in Ribeirão Preto, São Paulo (BR). Special thanks go to: Professors Geraldo da Silva e Souza and João Carlos Correia Baptista Soares de Mello for their valuable comments and suggestions concerning the methodological approach of my previous articles; and my colleagues João Thompson, André Velasco, Dina Smirnov, Eduardo Queiroga and Olivier de Groote, with whom I shared pleasant discussions and conversations.

I cannot forget to mention my co-workers from the Brazilian Innovation Agency (FINEP) for their patience and support during the final steps of my dissertation.

Lastly, I gratefully acknowledge the financial support provided by the National Council for Scientific and Technological Development $(\mathrm{CNPq})$ during my fellowship period. 


\section{Abstract}

De Oliveira, Erick Meira; Samanez, Carlos Patrício (Advisor); Macedo, Marcelo Alvado da Silva (Co-advisor). Corporate Social Responsibility and Firm Performance: a case study from the Brazilian Electric Sector. Rio de Janeiro, 2015. 172p. M.Sc. Dissertação - Departamento de Engenharia Industrial, Pontifícia Universidade Católica do Rio de Janeiro.

Research on the outcomes of Corporate Social Responsibility (CSR) on firm performance have garnered much interest in recent years, reflecting investors' growing awareness of social, environmental and corporate governance issues. The literature in this field, though vast, is littered with contradictory evidence. In addition, most studies lack a coherent set of metrics to assess CSR. Using a differentiated approach, in which firms' social responsibilities are evaluated within a multidimensional framework considering information from their annual social reports, this work aims to examine the relationship between CSR and firm performance in the Brazilian electric sector in recent years. The analysis is conducted in two basic steps: first, the Brazilian electric companies are classified according to the information disclosed from their social reports using a Data Envelopment Analysis Model. Then, several portfolios are formed based on firms' Environmental, Social and Governance (ESG) performances and are subsequently assessed using different financial metrics. The sample comprises a total of 36 electric companies and the time period of the analysis spans from 2009 to 2013. The results from both ex-post and ex-ante evaluations clearly indicate that portfolios comprising assets from firms with the best ESG practices not only offered the highest excess returns per unit of risk but also presented the lowest probabilities of large losses during the analysis period. In addition, firms that presented lower ESG performances but also released social reports during the years of portfolio formation performed significantly better than firms that did not disclose any social information within this time span.

\section{Keywords}

Corporate Social Responsibility; Financial performance analysis; Brazilian electric sector; Data envelopment analysis; Socially responsible investing. 


\section{Resumo}

De Oliveira, Erick Meira; Samanez, Carlos Patrício (Orientador); Macedo, Marcelo Alvado da Silva (Co-orientador). Responsabilidade Social Empresarial e Performance Financeira: Um Estudo de Caso do Setor Elétrico Brasileiro. Rio de Janeiro, 2015. 172p. Dissertação de Mestrado Departamento de Engenharia Industrial, Pontifícia Universidade Católica do Rio de Janeiro.

Os estudos acerca da relação entre desempenho socioambiental e desempenho financeiro das firmas tem ganhado considerável destaque nos últimos anos, refletindo o interesse cada vez maior de investidores em aspectos sociais, ambientais, éticos e governamentais das organizações. A literatura nesse campo é vasta, porém bastante contraditória. Além disso, a falta de critérios consistentes para se mensurar o desempenho socioambiental das empresas figura como principal argumento contra a veracidade das pesquisas empíricas voltadas para esse tema. Através de uma abordagem diferenciada, na qual o desempenho socioambiental é estimado dentro de um contexto multidimensional que considera informações dos relatórios sociais das firmas, esse trabalho busca analisar o desempenho financeiro de empresas socioambientalmente responsáveis do setor elétrico brasileiro, comparando-as com as demais integrantes do setor. Para tanto, uma primeira seleção é feita através de um modelo de Análise Envoltória de Dados, que busca mensurar a eficiência socioambiental das empresas com base em informações de seus balanços sociais. De posse desses resultados, propõe-se a formação de três grupos distintos: um primeiro formado apenas por empresas com os melhores desempenhos socioambientais; um segundo grupo que inclui empresas com desempenhos moderados, mas que também divulgaram resultados sociais durante o período de formação de carteiras; e um terceiro grupo que envolve todas as empresas que não divulgaram nenhuma informação socioambiental nos últimos anos. Em seguida, são montadas diversas carteiras teóricas para cada grupo de empresas, com composições diferenciadas de ativos de acordo com diferentes cenários. Essas carteiras são, então, comparadas segundo métricas específicas de avaliação de performance financeira. A amostra engloba um total de 36 companhias do setor elétrico brasileiro, analisadas entre os anos de 2009 a 2013. Os resultados, tanto da análise ex-post como da análise ex- 
ante, permitem constatar que as carteiras do primeiro grupo são claramente superiores, em termos de maiores prêmios de risco e menores probabilidades de perdas, às integrantes do segundo grupo e essas, por sua vez, dominam aquelas do último grupo. Dessa forma, pode-se inferir que houve, de fato, uma relação positiva entre desempenho socioambiental e desempenho financeiro das empresas do setor elétrico brasileiro nos últimos anos.

\section{Palavras-chave}

Responsabilidade Social Empresarial; Análise de Performance Financeira; Setor Elétrico Brasileiro; Análise Envoltória de Dados; Investimentos socioambientalmente responsáveis. 


\section{Contents}

1 Introduction $\quad 17$

$\begin{array}{lr}1.1 \text { Preliminary remarks } & 17\end{array}$

1.2 The point of tension 20

1.3 Motivation 21

1.4 Outline of this dissertation 22

2 Theoretical Background 24

2.1 CSR throughout history 24

2.1.1 Footprints of social responsibility 24

2.1.2 First concepts - Corporate managers as public trustees 25

2.1.3 1960's and 1970's - Corporations beyond voluntary philantrophy 26

2.1.4 1980's and 1990's - Business ethics and social contract 28

2.1.5 1990's and 2000's - Corporate global citizenship 30

2.2 Assessing CSR 34

2.2.1 CSR on business practice: rhetoric versus practice 34

2.2.2 CSR disclosure in social reports: a sensible solution 34

2.2.3 Evaluating CSR in financial markets: ESG performance 36

$\begin{array}{ll}\text { 2.2.4 The new frontiers on ESG reporting } & 37\end{array}$

2.3 CSR and Financial Performance $\quad 39$

2.3.1 CSR outcomes on firm performance: opposing views 39

2.3.2 Academic interest in nonfinancial information 41

2.3.3 Social Responsibility and Portfolio Performance 41

2.4 CSR and FP in Brazil 43

2.4.1 CSR practices in Brazil 43

2.4.2 CSR disclosure of Brazilian firms 44

2.4.3 Academic output related to CSR and FP in Brazil 46

3 Methodology 49

3.1 Data Envelopment Analysis 49

3.1.1 Efficiency measurement concepts 49

3.1.1.1 Input-oriented measures $\quad 50$

3.1.1.2 Output-oriented measures $\quad 52$

3.1.1.3 Further concepts in DEA

3.1.2 DEA models 56

3.1.2.1 The CCR/CRS model 56

3.1.2.1.1 A footnote on slacks 58

3.1.2.1.2 Output-oriented CCR/CRS 62

3.1.2.2 The BCC/VRS model 63

3.1.2.3 CCR vs BCC and scale efficiencies 66

3.1.3 CSR evaluation using ESG metadata 67

3.2 Portfolio Formation $\quad 70$

3.2.1 Firm groups 70

3.2.2 Classes of portfolios $\quad 70$

3.2.3 Risk and expected return of portfolios 71

3.2.3.1 Diversifiable and systematic risks 72

3.2.4 Minimum variance portfolios $\quad 75$ 
3.2.4.1 Modern portfolio theory 75

3.2.4.2 Constrained global minimum-variance portfolios 79

3.2.5 Maximum Sharpe portfolios $\quad 80$

3.2.6 Additional topics on portfolio formation 82

3.2.6.1 Guidelines for portfolio formation 82

3.2.6.2 The Sharpe ratio benchmark for portfolio formation 83

3.2.6.3 The beta of a portfolio 83

3.2.6.4 Tests for stationarity $\quad 84$

3.3 Portfolio Evaluation 86

3.3.1 Sharpe Ratio (ShR) 86

3.3.2 Treynor Ratio (TrR) 86

3.3.3 Jensen Ratio (JnR) 87

3.3.4 Sortino Ratio (SoR) 88

3.3.5 Omega Ratio $(\Omega) \quad 89$

3.3.6 Additional topics on portfolio evaluation 90

$\begin{array}{ll}\text { 3.3.6.1 Test for normality } & 90\end{array}$

3.3.6.2 Performance evaluation tools: summary 91

4 Results and discussion 93

$\begin{array}{ll}\text { 4.1 Sample } & 93\end{array}$

4.2 ESG performance $\quad 95$

4.3 Data handling and portfolio formation 98

4.4 Ex-post evaluation 99

4.4.1 Preliminary data on risk-return composition 99

$\begin{array}{lr}\text { 4.4.2 Financial performance indicators } & 101\end{array}$

4.4.3 Financial behaviour over the years 107

$\begin{array}{ll}4.5 \text { Ex-ante evaluation } & 109\end{array}$

4.5.1 Preliminary data on risk-return composition 110

$\begin{array}{ll}\text { 4.5.2 Financial performance indicators } & 111\end{array}$

$\begin{array}{ll}\text { 4.5.3 Financial behaviour over the years } & 117\end{array}$

$\begin{array}{ll}4.6 \text { Discussion } & 120\end{array}$

5 Conclusions and final remarks $\quad 122$

$\begin{array}{ll}\text { References } & 124\end{array}$

$\begin{array}{ll}\text { Appendix A - Assets included in portfolio formation } & 134\end{array}$

$\begin{array}{ll}\text { Appendix B - Assets excluded from the analysis } & 139\end{array}$

Appendix C - Data Envelopment Analysis - Data for inputs and

outputs 145

Appendix D - Publicly traded assets available for portfolio formation and $\begin{array}{ll}\text { test results for stationarity and normality } & 149\end{array}$

$\begin{array}{ll}\text { Appendix E - Formed portfolios } & 151\end{array}$ 
Appendix G - Ex-post portfolios - Return probability distribution and sensitivity of Omega measure in relation to the minimum expected return

Appendix $\mathrm{H}-E x$-ante portfolios - Sensitivity of Omega measure results in relation to the minimum expected return 


\section{List of Figures}

Figure 1 - UNIDO's approach to CSR based on CED three-tiered model 28

Figure 2 - Carroll's (1991) pyramid of corporate social responsibility 31

Figure 3 - Perceptions of CSR throughout the years 33

Figure 4 - ESG gaps between company managers and asset managers 38

Figure 5 - Technical and allocative efficiencies 51

Figure 6 - Piecewise-linear convex isoquant 52

Figure 7 - Input and output-oriented technical efficiency measures and returns to scale

Figure 8 - Technical and allocative efficiencies from an output orientation

Figure 9 - Efficiency measurement and input slacks $\quad 59$

Figure 10 - Efficiency measurement and input slacks $\quad 64$

Figure 11 - The components of total investment risk 75

Figure 12 - Investment opportunity set of attainable portfolios 78

Figure 13 - The CAPM Security Market Line and the Jensen's alpha 88

Figure 14 - The cumulative distribution of a portfolio's returns 90

Figure 15 - Indices and firm groups ex-post performances

(whole period)

104

Figure 16 - IBOVESPA, IEE and ISE historical data (2009-2012).

Base fitted for 1000 points on 31/12/2008.

107

Figure 17 - Portfolios A (2009-2012). Base fitted for 1000 points on 31/12/2008.

108

Figure 18 - Portfolios B (2009-2012). Base fitted for 1000 points on 31/12/2008.

Figure 19 - Portfolios C (2009-2012). Base fitted for 1000 points on 31/12/2008.

Figure 20 - Portfolios D (2009-2012). Base fitted for 1000 points on $31 / 12 / 2008$.

Figure 21 - Indices and firm groups ex-ante performances

(whole period)

Figure 22 - IBOVESPA, IEE and ISE historical data (2010-2013).

Base fitted for 1000 points on 31/12/2009.

Figure 23 - Portfolios A (2010-2013). Base fitted for 1000 points on 31/12/2009.

Figure 24 - Portfolios B (2010-2013). Base fitted for 1000 points on 31/12/2009.

Figure 25 - Portfolios C (2010-2013). Base fitted for 1000 points on 31/12/2009.

Figure 26 - Portfolios D (2010-2013). Base fitted for 1000 points on $31 / 12 / 2009$. 


\section{List of Tables}

Table 1 - Performance evaluation measures 92

Table 2 - Initial sample $\quad 94$

Table 3 - DEA efficiency results $\quad 96$

Table 4 - Ex-post evaluation: Preliminary data on risk-return
composition

Table 5 - Ex-post - Sharpe, Treynor and Jensen measures

(whole period) 102

Table 6 - Ex-post - Sortino and Omega ratios (whole period) 103

$\begin{array}{ll}\text { Table } 7 \text { - Ex-ante evaluation: Preliminary data on risk-return } & \\ \text { composition } & 110\end{array}$

$\begin{array}{ll}\text { Table } 8 \text { - Ex-ante - Sharpe, Treynor and Jensen measures } & 112 \\ \text { (whole period) } & \end{array}$

Table 9 - Ex-ante - Sortino and Omega ratios (whole period) 113 


\section{List of Acronyms}

AE

ASR

BCC/VRS

BM\&FBOVESPA

CAL

CCR/CRS

CDI

CRSP

CSP

CSR

CSRD

CSS

DEA

DMU

EE

ESG

FP

GMV

GRI

IBASE
Allocative Efficiency

Annual Savings Rate

Banker, Charnes and Cooper/Variable returns to scale

Brazilian Mercantile, Futures and Stock Exchange

Capital Allocation Line

Charnes, Cooper and Rhodes/Constant returns to scale

Interbank Deposit (rate)

Center for Research in Security Prices

Corporate sustainability performance

Corporate social responsibility

Corporate social responsibility disclosure

Common Stock Symbol

Data envelopment analysis

Decision making unit

Economic Efficiency

Environmental, social, and corporate governance

Financial performance

Global Minimum-variance (portfolio)

Global Reporting Initiative

Brazilian Institute of Social and Economic Analysis 
IBOVESPA

IEE

ISE

$\mathrm{JnR}$

MPT

MShR

NAR/Totex

OTC

$\mathrm{R}_{\mathrm{f}}$

$\mathrm{R}_{\min }$

ShR

SoR

SRI

TE

$\operatorname{TrR}$

UNIDO
BOVESPA Index (market portfolio)

Electric Power Index

Corporate Sustainability Index

Jensen ratio

Modern Portfolio Theory

Maximum Sharpe Ratio Portfolio

Ratio between net annual revenue and total expenditure in environmental activities

Over-the-counter (market)

Risk-free rate

Minimum threshold, minimum accepted return (MAR)

Sharpe ratio

Sortino ratio

Socially responsible investing

Technical Efficiency

Treynor ratio

United Nations Industrial Development Organization 
"Put love in all things you do and they will make sense. Take love away and they become worthless and empty".

(St Augustine - Sermon 138, 2) 


\section{1 \\ Introduction}

1.1

Preliminary remarks

Researchers have long argued that corporate responses to environmental issues should be kept at the minimum level required. However, in the previous decades, this view has come under increasing criticism. Business firms, whose only concern was once considered to increase their profits, now play a greater role in many aspects of our lives. Not only have such firms incorporated a range of environmentally friendly technologies and processes, but they have also engaged in activities traditionally regarded as governmental. Corporate involvements in public health, education, social security, and the protection of human rights, as well as cooperation with non-governmental organisations (NGOs) and non-profit organisations (NPOs), are common examples of these companies' efforts to become more socially responsible.

Society as a whole is also changing the way companies' performances are assessed. As the emphasis of corporate social responsibility (CSR) becomes more widely accepted, the general public starts to make decisions based on criteria that include ethical concerns, such as environmental protection and employee wellbeing. Different stakeholders, including customers, suppliers, employees, communities, investors, and activist organisations, have all started to question companies' ethics and responsibility toward society and local communities. Governments, in turn, apart from their general competencies in setting the policy framework, are further called upon to recognise firms' positive attitudes towards the environment, either by granting tax relief or tax advantages or by backing lowinterest loans or initiating public-private partnerships.

The ongoing mobilisation on behalf of social and environmental responsibility has also reached the financial markets. One of the groundbreaking events in this area was the establishment of a platform associating the United 
Nations and the global financial sector. The United Nations Environment Programme Finance Initiative (UNEP FI), as it became known, was founded in 1992 in the context of the Earth Summit in Rio, and it works with nearly 200 financial institutions as well as a range of partner organisations to recognise and promote the links between sustainability and financial performance (UNITED NATIONS ENVIRONMENT PROGRAMME FINANCE INITIATIVE, 2014). Another landmark event in this regard was the signing of the Equator Principles in 2003, a credit risk management framework for determining, assessing, and managing environmental and social risk in project finance transactions (THE EQUATOR PRINCIPLES, 2014).

More recently, as increased stakeholder pressure requires companies to be transparent, corporate social responsibility disclosure (hereafter CSRD) has been perceived as a tool of a firm's increasing transparency and credibility in financial markets. Even though no framework for nonfinancial reporting has risen to the level of International Financial Reporting Standards (IFRS), many publicly traded companies voluntarily disclose relevant information on governance, environmental and social responsibility. Regarding this matter, the United Nations-supported Principles for Responsible Investment (UN PRI) is considered as a benchmark for CSR disclosure. The Principles, first launched in April 2006 at the New York Stock Exchange, are voluntary and aspirational, offering a menu of possible actions for incorporating environmental, social, and corporate governance (ESG) issues into investment practices across asset classes (PRINCIPLES FOR RESPONSIBLE INVESTMENTS, 2014). Another example is the Global Reporting Initiative's (GRI) Framework, a reporting system that enables all companies and organisations to measure, understand and communicate ESG information. The GRI Sustainability Reporting Guidelines, currently in its fourth generation, offer reporting principles, standard disclosures and an implementation manual for the preparation of sustainability reports by organisations, regardless of their size, sector or location (GLOBAL REPORTING INITIATIVE, 2014). Finally, the utmost reference concerning ESG disclosure is Bloomberg's ESG data system. Since 2009, Bloomberg Finance has uploaded company ESG data to its financial service platform. Corporate ESG data is typically released through annual corporate sustainability reports. Bloomberg 
currently provides data on more than 120 ESG key performance indicators for approximately 5,000 publicly listed companies globally, and is increasing coverage every day (BLOOMBERG, 2014).

In recent years, environmental issues and CSR disclosures have also become important in emerging markets. For instance, in Brazil, most major companies now have a department of corporate social responsibility and seek to link their social and environmental responsibilities to their core business. Brazilian companies practise social responsibility with a degree of sophistication unparalleled in Latin America (SCHARF, 2008). In the readers' prize for sustainability reporting that is awarded by the Global Reporting Initiative (GRI), Brazilian companies captured eight out of 24 nominations and two of eight prizes in 2008 (GLOBAL REPORTING INITIATIVE, 2014). In addition, by the end of 2011 the overall amount of GRI's disclosure data in Brazilian companies was growing by an average of $88 \%$ annually (KPMG INTERNATIONAL, 2011).

Civil society and the media in Brazil also address the topics of corporate responsibility and sustainability. For instance, a recent poll suggested that $52 \%$ of Brazilians are willing to pay more for environmentally friendly products (INFOMONEY, 2012). Public opinion surveys conducted over the past decade at the request of the Brazilian Ministry of Environment (MMA) suggest that Brazilians lead in their concern about environmental issues, with over $90 \%$ perceiving air pollution, climate change, biodiversity loss or water availability as serious problems - at least 30 percentage points more than the international average (BRAZILIAN MINISTRY OF ENVIRONMENT, 2012). With regard to the Brazilian financial markets, much has been achieved. In July 2013, the Brazilian Mercantile, Futures and Stock Exchange (BM\&FBOVESPA) approved its own sustainability policy, consisting of market, environmental, social, and corporate governance initiatives. In addition, by May 2012 over 75\% of the top 100 BM\&FBOVESPA companies had already been publishing CSR reports on an annual basis (BRAZILIAN MERCANTILE, FUTURES AND STOCK EXCHANGE, 2013). Despite BM\&FBOVESPA's efforts to foster CSR disclosure in Brazil, problems of low comparability between reports of different companies have been observed. The Brazilian electric sector could be an exception to this issue, since the disclosure of their social reports is regulated by 
the Brazilian National Agency for Electricity (ANEEL), which determines the use of the Brazilian Institute of Social and Economic Analysis (Ibase) model as standard.

\section{2}

\section{The point of tension}

Amongst the many dramatic changes that have taken place in the business world since the last century, the rise of the CSR agenda is certainly one of the most noteworthy. Even so, there is still a protracted debate about the legitimacy and value of corporate responses to Corporate Social Responsibility (CSR) concerns. In short, from the very start of the discussions, two conflicting visions have shaped thoughts about the outcomes of CSR on firm performance: Friedman's (1970) shareholders ${ }^{1}$ theory and Freeman's (1984) stakeholders theory, briefly explained in the following lines.

On September 13, 1970, the New York Times featured an article by economist Milton Friedman in which he wrote:

[...] There is one and only one social responsibility of business - to use its resources and engage in activities designed to increase its profits so long as it stays within the rules of the game, which is to say, engages in open and free competition without deception or fraud. (FRIEDMAN, 1970)

Friedman's argument is partially sound. Certainly, adopting CSR principles involves costs, which might be short term in nature or continuous outflows. In addition, it can be argued that when competitive corporations maximise profits, production is achieved as efficiently as possible, yielding maximum welfare for society. This view continues to be held by influential economists such as David Henderson, Robert Reich and others.

On the other hand, the assumptions underlying Freeman's (1984) stakeholder theory are rooted in the concepts of the "unavoidability of normative

\footnotetext{
${ }^{1}$ It is worth noting that this theory is sometimes called the "stockholder" theory as well.
} 
conformity with the social environment" (PALAZZO \& SCHERER, 2006). Although this may look as bringing to surface moral factors, the key point of the underlying rationale is that CSR is indeed a necessity, not a choice. In other words, following Sethi (1975), since corporations operate within the boundaries of society, of which they are an integral part, it is conceptualised that they depend upon society for their continuity and growth.

In the end, the fundamental distinction between the two visions, according to Hasnas (1998), is that, under the shareholder theory, nonshareholders can be viewed as "means" to the "ends" of profitability whilst under the stakeholder theory, the interests of many nonshareholders are also viewed as "ends".

\section{3 Motivation}

Although debate about CSR and ESG data has continued to grow, we remain a long way from consensus about their effects on a firm's financial performance in capital markets. The literature in this field is vast but littered with contradictory evidence. Griffin and Mahon (1997), for instance, summarised their findings of numerous articles and inferred that there is no agreement on the relationship between CSR and financial performance. Others authors, such as Neu et al. (1998) and Cormier et al. (2005) claim that this relationship is complex and that the investigative process is methodologically subjective. In addition, most studies lack a coherent set of metrics to assess CSR. Social responsibility is often evaluated in a simplified and superficial manner and little is known about the degree to which CSR practices have penetrated the fabric of business behaviour. According to Godfrey and Hatch (2007), in order to gain a better insight of CSR influence on business practice, research must focus on the specific policies and activities through which managers try to implement a theoretical commitment to social, environmental and economic goals. At the moment, there is a recognised shortage of dedicated studies on this subject (LINDGREEN \& SWAEN, 2010). To best of our knowledge, no work addressing these issues has been done in Brazil. 
In the context of the above-mentioned situation, and considering the important role that CSR has taken in the Brazilian financial market in recent years, this work aims to investigate whether CSR has established a relationship with firms' financial performance in the Brazilian electric sector in recent years. To achieve this goal, the analysis is conducted in two basic steps: first, the Brazilian electric companies are classified according to the information disclosed from their annual social reports using a Data Envelopment Analysis Model. Then, several portfolios are formed based on firms' ESG performances and are subsequently assessed using different financial metrics. The financial performances of each group portfolio are not only compared relative to one another, but also with the IBOVESPA, ISE and IEE indices, three proxies representing: the Brazilian market portfolio, the performance of a maximum of 40 Brazilian companies selected on the basis of sustainability guidelines, and the performance of the Brazilian electric sector, respectively. The analysis is carried out both ex-post, i.e., at the same years when portfolios are formed, and ex-ante, where portfolios' performances are assessed in the subsequent year following their formation, and where market behaviour is not known a priori. The sample comprises a total of 36 electric companies and the time period of the analysis spans from 2009 to 2013.

Foreshadowing our main results, we find that the involvement of Brazilian electric companies in CSR practices and their financial outcomes in recent years possibly match with what Freeman's (1984) stakeholder theory claims. In other words, companies fulfilling their fiduciary duty to society and disseminating their social outcomes to the general public typically performs better than those that do not invest in sustainable practices nor produce social reports.

\section{4 Outline of this dissertation}

Besides this Chapter, where we stated the main reasons and objectives of this work, the remainder of this dissertation is organized as follows: Chapter 2 presents the theoretical background of the research, Chapter 3 discusses the methodology and metrics we use in our experiments, Chapter 4 reports and 
discusses the results, and Chapter 5 summarises the results with the aim of offering conclusions and proposals for future research.

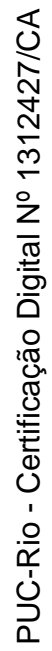




\section{2 \\ Theoretical Background}

Corporate Social Responsibility (CSR) has turned into a high-profile public issue in modern society. With the advent of concepts such as Socially Responsible Investing (SRI), also labeled ethical or sustainable investing (RENNEBOOG et al., 2008), and environmental, social and corporate governance (ESG) factors, the general public has started making decisions based on criteria that include ethical concerns, such as environmental protection and employee wellbeing. Different stakeholders, including customers, suppliers, employees, communities, investors, and activist organisations, have all started to question companies' ethics and responsibility toward society and local communities. An extensive global survey found that two-thirds of people reported that they would like companies to contribute to social goals beyond shareholder wealth (ENVIRONICS INTERNATIONAL, 1999).

Given the serious and genuine commitment to CSR in recent years, this Chapter is devoted to summarise the evolution of this concept throughout history and to review and evaluate the theoretical and empirical literature that has underpinned its relationship with firm performance over the years.

\section{1}

\section{CSR throughout history}

\subsection{1}

\section{Footprints of social responsibility}

Although the idea of Corporate Social Responsibility (CSR) is a fairly recent incarnation, its origins are probably as old as business and trade itself. The roots of extended responsibility of farming, manufacturing and trading entities beyond the boundaries of profit and growth can be traced back to ancient 
Mesopotamia, nearly 4000 years ago. with the writing of the code of Hammurabi. The code provided laws and rights to builders, farmers and innkeepers to conduct their business in such a way as not to cause mortal injury to anyone, under penalty of death.

Religious and philosophical issues have played a major role in developing the foundations of social responsibility worldwide. The role of business in the sustainability and protection of the environment is well recognised and encouraged in the teachings of Kautilya's Arthasastra (ca. 350-283 B.C.), whose scriptures provided an inside-out approach to CSR in India, there described as the development of the individual leader's self-conscience (MUNIAPAN \& DASS, 2008). For generations, religious investors have avoided partnering or investing with those who earned their money through alcohol, tobacco, weapons or gambling, as outlined in Skillius and Wennberg (1998).

\subsection{2 \\ First concepts - Corporate managers as public trustees}

While the idea that businesses were responsible for their actions in a sphere somewhat wider than that covered by their profit-and-loss statements dates back millennia, formal or scholarly writing on social responsibility is largely a product of the $20^{\text {th }}$ century, as stated by Carroll (1999).

The concept of social responsibility was first put in words by Bowen (1953), who stated that: "It refers to the obligations of businessmen to pursue those policies, to make those decisions, or to follow those lines of action which are desirable in terms of the objectives and values of our society."

Although still vague in the sense that he did not provide any definitions for the objectives and values of society at that time, Bowen's rationale is considered a landmark event in the new era of CSR, since he was the first to address the idea of corporate managers as public trustees. Generally speaking, considering that the actions of firms touched the lives of citizens at many points, businessmen had an obligation to account for social objectives and values when making their decisions. 
Bowen's seminal work on the definition of corporate social responsibility marked the beginnings of a series of studies on this subject. Important contributions addressing this topic can be found in Eells' (1956) Corporate Giving in a Free Society, Heald's (1957) Management's Responsibility to Society and Selekman's (1959) Moral Philosophy for Management.

\subsection{3}

\section{0's and 1970's - Corporations beyond voluntary philantrophy}

Prior to the early 60s, CSR had been approached in the managerial world through notions as diverse as "stewardship" and "trusteeship", according to Frederick (2008). The decade of the 1960s, however, brought significant changes to the concept of CSR.

Society's perceptions on the growing reach and influence of companies spawned more aggressive demands for corporations to set their sights on employee wellbeing, environmental protection, labour standards, fair prices to consumers, among others. As a result, organisations reacted by adopting a proactive attitude towards socialy responsibility, focusing on response rather than passive, voluntary responsibility.

This new vision of "Corporate Social Responsiveness" is clearly outlined in the works of Davis (1960) and Frederick (1960), two prominent writers in that period. Davis (1960) stated that social responsibility referred to "businessmen's decisions and actions taken for reasons at least partially beyond the firm's direct economic or technical interest". Frederick (1960), in turn, wrote:

[...] [Social responsibilities] mean that businessmen should oversee the operation of an economic system that fulfills the expectations of the public. And this means in turn that the economy's means of production should be employed in such a way that production and distribution should enhance total socio-economic welfare.

Social responsibility in the final analysis implies a public posture toward society's economic and human resources and a willingness to see that those resources are used for broad social ends and not simply for the narrowly circumscribed interests of private persons and firms. (FREDERICK, 1960, p. 60) 
Following Davis (1960) and Frederick (1960), a number of different varieties, or models of social responsibility were proposed in the 1960s. Important contributions addressing this topic can be found in McGuire (1963), Davis and Blomstrom (1966) and Walton (1967).

The growing activity and sophistication of "civil society" organisations generated pressure on corporations to take CSR seriously. New incentives and sanctions encouraged socially responsible behaviour on the part of managers and employees. Stakeholders affected by company operations were identified and brought into negotiation. In 1971, the Committee for Economic Development (CED) published its Social Responsibilities of Business Corporations, outlining a three-tiered model of corporate social responsibility (CSR): the inner circle, regarding the basic responsibilities of an organization to create profit; the intermediate circle, where corporations must be sensitive to the changing social contract that exists between business and society when they pursue their economic interests; and the outer circle, representing the responsibilities a firm needs to pursue to improve the social environment (COMMITTEE FOR ECONOMIC DEVELOPMENT, 1971).

The CED's three-tiered model is considered a noteworthy contribution to the field of CSR since it provided further insights into the role played by business firms in society. It has been such a useful tool that it has served as a basis for other institutions' approach to CSR, for instance, UNIDO's Triple Bottom Line (TBL) model, as depicted in Figure 1.

Another landmark event in the history of CSR was the debate involving Economics Professors Henry G. Manne and Henry C. Wallich. The debate, sponsored by the American Enterprise Institute in 1972, triggered discussions about the value of corporate responses to CSR concerns, and was later summarised in their volume The Modern Corporation and Social Responsibility (MANNE \& WALLICH, 1973).

For more insight on the substantial changes concerning the concept of CSR and the main causes behind its expansion in the 1960s and 1970s, the interested reader is referred to Ackerman (1975), Preston and Post (1975) and Carroll (1979). 
Figure 1 - UNIDO's approach to CSR based on CED three-tiered model

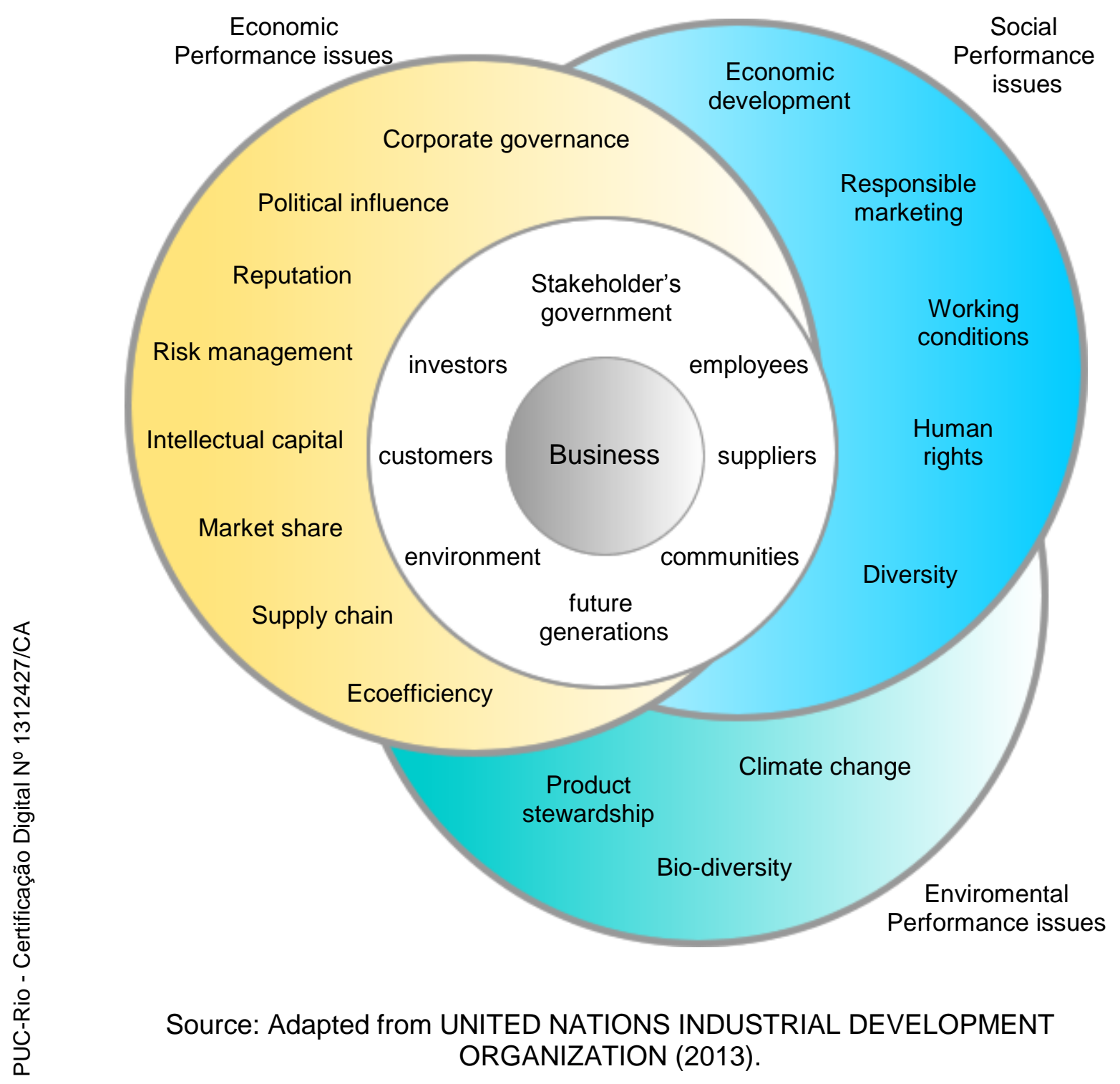

\section{1 .4}

1980's and 1990's - Business ethics and social contract

The 1980s were ushered in with alternative concepts and themes such as corporate social responsiveness, public policy, business ethics, and stakeholder theory/management. According to Carroll (1999), the interest in CSR did not die out; rather, the core concerns of CSR began to be "recast" into alternative concepts, theories, models or themes. 
A noteworthy contribution to the CSR debate at that time was that of Jones (1980) who, in light of the difficulties to assess socially responsible behaviour, alleged that CSR ought to be seen not as a set of outcomes but as a process.

Deal and Kennedy (1982), in turn, set forth the idea that culture holds the key to charting a socially responsible path for organisations. In other words, every business firm has a distinctive organisational culture that exerts a considerable influence not only on its actions and goals but specially on its employees. To this end, firms can make use of a wide array of instruments, such as: codes of ethics defining core values and ethical principles; ethics audits; positive rewards for exemplary conduct on the job; among others.

The concept of business ethics is also clearly outlined on Carroll's (1983) new definition on CSR:

[...] CSR involves the conduct of a business so that it is economically profitable, law abiding, ethical and socially supportive. To be socially responsible [...] then means that profitability and obedience to the law are foremost conditions to discussing the firm's ethics and the extent to which it supports the society in which it exists with contributions of money, time and talent. Thus, CSR is composed of four parts: economic, legal, ethical and voluntary or philanthropic. (CARROLL, 1983, p. 604)

Epstein (1987), in an attempt to relate abstract concepts of social responsibility, responsiveness and business ethics, provided an alternative definition of CSR:

[...] Corporate social responsibility relates primarily to achieving outcomes from organizational decisions concerning specific issues or problems which (by some normative standard) have beneficial rather than adverse effects on pertinent corporate stakeholders. The normative correctness of the products of corporate action have been the main focus of corporate social responsibility. (EPSTEIN, 1987, p. 104)

Epstein (1987) argued that "corporate social policy process is the institutionalization within business organisations of the following three elements: business ethics, corporate social responsibility and corporate social responsiveness". 
The plethora of policy instruments concerning business ethics prompted the concept of a social contract between firm and society where specific responsibilities are defined for each side. Formal writing on this issue can be found in the work of Donald and Dunfee (1994). In their "Integrative Social Contracts Theory" (ISCT), Donaldson and Dunfee propose a communitarian conception of economic morality, which consists of two distinct contracts. The first is a normative and hypothetical contract among economic participants, commonly referred to as macrosocial contract, which comprises ethical principles that put ethical boundaries on actions and behaviour in all situations. The second, in turn, is an existing (extant) implicit contract that prescribes what constitutes ethically permissible behaviour and what does not. This microsocial contract, as it is usually referred to, can occur among members of specific communities, including firms, departments within firms, informal subgroups within departments, national economic organisations, international economic organisations, professional associations, industries etc. The first contract defines the normative ground rules for creating the second kind of contract. For further details on ISCT, the interested reader is referred to excellent reviews on the subject (DOUGLAS, 2000; DUNFEE, 2006).

\subsection{5 \\ 1990's and 2000's - Corporate global citizenship}

The 1990s and early 2000s, in front of the globalization process, witnessed a dramatic acceleration of corporate involvement into society. The social responsibility of corporations became worldwide in scope and magnitude. In this context, corporate reputation gained considerable attention in both the academy and in practice. Donaldson's (1991) book The Ethics of International Business stands out during this period for its initiative to link international business, the forces of globalization, and business ethics. The book, which is also considered as the forerunner of the Integrative Social Contract Theory, offers three concepts for interpreting international business ethics: a social contract between productive organisations and society; the notion of a fundamental international right, promulgated by ten specific international rights; and a moral 
"algorithm" to help multinational managers make tradeoffs between conflicting norms in home and host countries.

In the course of everyday business, managers were increasingly faced with many ethical dilemmas, involving standards, rules of conduct, perceptions and moral judgements regarding what is right or wrong. In the light of the above, Carroll (1991) suggested that the concept of "corporate citizenship" should be embraced as a discretionary responsibility in his famous four-layered pyramid of CSR model, as illustrated in Figure 2.

Figure 2 - Carroll's (1991) pyramid of corporate social responsibility

\section{Discritionary} Responsibilities

Contribute resources to the community

Ethical Responsibilities

Obligation to do what is right, just and fair.

\section{Legal Responsibilities}

Law is society's codification of right and wrong

\section{Economic Responsibilities}

The foundation upon which all others rest

Source: Adapted from Carroll (1991).

According to Frederick (2008), the concept of corporate citizenship embodies all definitions discussed in the previous sections, i. e. corporate social stewardship/philanthropy (1950s-1960s), corporate social responsiveness/social activism (1960s-1970s) and business ethics (1980s-1990s). In addition, it also opens up the vista of companies as truly corporate global citizens. By this token, 
corporations are further called upon to adopt measures addressing global challenges, such as sustainable development, climate change, clean water, depollution of air, oceans, arable land, forests, global ethics, health issues, education, energy supply, among many others. Some scholars, such as Fort and Schipani (2002) have even proposed that global corporations could take on the role of peacemakers in a world of rising tensions.

Although it is taken for granted that the focus of CSR throughout history has moved from philosophical and religious principles within corporations to global ecological issues, social problems and business ethics, as briefly illustrated in Figure 3, there is no such thing as a final definition to CSR. CSR continues, as it should, to be discovered and expressed in varying ways that parallel the sociocultural diversity of values found throughout the world. In this context, empirical research is of the utmost importance, so that practice may be reconciled with theory.

Last, but not least, one should keep in mind that CSR is simultaneously dynamic, overlapping and contextual. Unevenly developed and experienced throughout the world, the concept of CSR is largely dependent on a region's physical, environmental, social and cultural characteristics. 
Figure 3 - Perceptions of CSR throughout the years

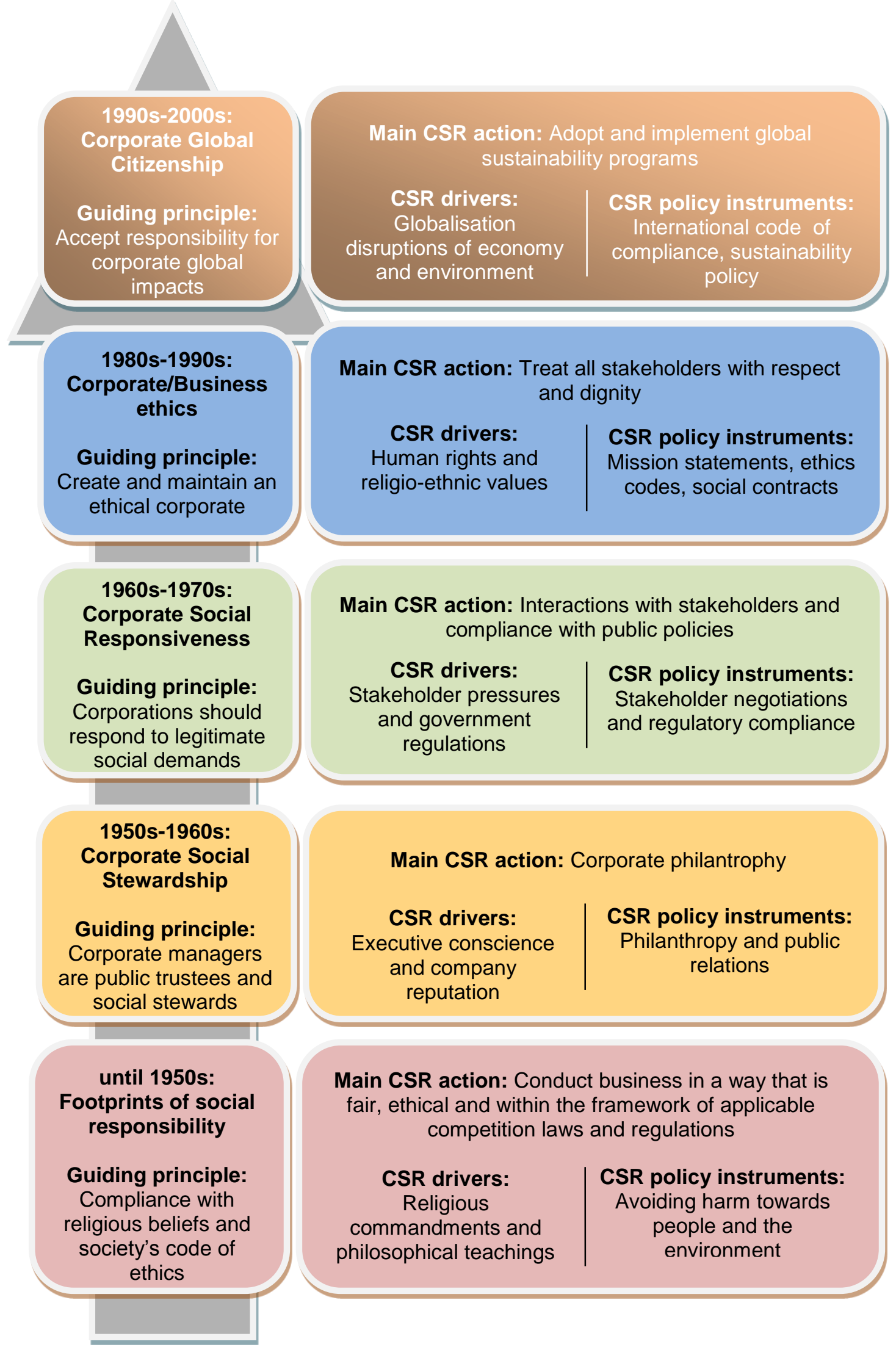

Source: Adapted from Frederick (2008). 


\section{2 \\ Assessing CSR}

\subsection{1}

CSR on business practice: rhetoric versus practice

At first glance, it may appear that firms eagerly respond to public concerns regarding their operations and engage in socially responsible practices. Nevertheless, there is a significant discrepancy between CSR rhetoric and practice. Conflicts on corporate political involvement/strategies, unhealthy political ties, corruption, doubtful attitudes, lack of transparency, among others are common examples of corporate misconduct which remains up to present day. Such contradictions leave the influence of CSR on business practice open to interpretation.

Current research also falls short to address CSR in practice. King and Lenox (2000), for instance, argues that the use of limited in scope approaches and a focus on rhetoric at the expense of concrete action hinder attempts to assess firms' performance with regard to CSR. Heugens et al. (2008), in turn, assert that explicit consideration of organizational values, and the commitments that result from that internal organizational template, i.e., corporate governance, is often overlooked when evaluating firms' actions towards social responsibility. Muller and Kolk (2010) state that both intrinsic and extrinsic drivers of foreign and local firms' social behaviour should be explored when assessing CSR.

In short, although debate about CSR has continued to grow over the years, knowledge of the degree to which CSR practices have penetrated the fabric of business behaviour has remained a challenge to-date.

\section{2 .2}

\section{CSR disclosure in social reports: a sensible solution}

In the absence of a coherent set of metrics for assessing CSR in practice, Corporate Social Responsibility Disclosure (henceforth CSRD) has been 
perceived over the years as a satisfactory proxy to evaluate the manner and extent to which businesses are responding to social responsibility concerns. According to Dowling and Pfeffer (1975), CSRD helps to assess the congruence between the social value implied by corporate activities and the social norms in a consistent manner. In addition, CSRD may considerably enhance corporate reputation through gaining trust and support by various stakeholders, giving firms a compelling reason to become more socially responsible and to disseminate their outcomes to the general public.

CSR disclosures have been the focus of much academic research since the mid-1970s. Ernst and Ernst (1978) examined social and environmental related information in the annual reports of Fortune 500 companies between 1972 and 1978. Their findings indicated that the vast majority of these companies had disclosures related to one or more of these topics: fair business practices, community involvement and the local environment. In assessing the content of the disclosed information embedded in the annual reports of 150 companies from the U.S., the U.K. and Australia, Guthrie and Parker (1990) noticed that such documents mainly covered six themes: human resources, community involvement, environment, energy, products, and others. Roberts (1992), in turn, suggests that measures of stakeholder power, strategic posture, and economic performance are significantly related to levels of corporate social disclosure.

Meanwhile, some authors examined the content of annual reports in developing countries (ANDREW et al., 1989; TSANG, 1998; BELAL, 2001). All were unanimous in claiming that the level of CSR disclosures in these countries were relatively poor in comparison with developed countries and were mainly focused on the area of human resources and community involvement.

Disregarding specific issues related to the quality and amount of CSR information disclosed throughout the globe, in most studies on CSRD, a content analysis approach is used based on information from firms' social reports. Hughes et al. (2001) also cited the frequent use of annual reports in CSR disclosure studies. They argued that this is due to "[...] their wide availability and the perception that this is the medium most often used by corporations to communicate in a systematic manner with shareholders". Milne and Adler (1999) add that the construction of a categorization scheme is an essential stage in 
content analysis research. This involves the selection and development of categories into which content units can be classified (TILT, 2000).

\subsection{3 \\ Evaluating CSR in financial markets: ESG performance}

There is no disputing that the vast majority of CSR disclosures mainly address the social and environmental conducts of firms and their organizational values. In this context, and considering that stakeholders require CSR information to be both quantitative and measurable so that it can be compared across companies and through time, a new set of metrics has emerged in financial markets to account for this need: the environmental, social and corporate governance performance (ESG) indicators.

The rise of ESG data dates back to the United Nations Environment Programme Finance Initiative publication The Materiality of Social, Environmental and Corporate Governance Issues to Equity Pricing (UNEP FI, 2004) and is partly grounded in the shortcomings of traditional financial valuation models, which cannot fully price the value of CSR into asset pricing. By this token, stakeholders, particularly investors and societal stakeholders, required a consistent framework to estimate the value of intangible assets such as reputation, trust and capacity to innovate.

Society, in its turn, has started to realise that for business to genuinely take on the role as provider of goods and services that address global challenges, capital markets need to be updated and aligned to capture long-term company value and promote a more sustainable path of development. ESG factors ultimately fall within this purview.

In light of the above, notwithstanding the difficulties in forming networks of communication around ESG integration and the fact that no framework for nonfinancial reporting has risen to the level of International Financial Reporting Standards (IFRS), there is growing evidence to suggest that ESG-focused investing is the future of socially responsible investment. A landmark event in this regard was the enactment of the United Nations-supported Principles for 
Responsible Investment (UN PRI), considered as a benchmark for CSR disclosure up to present date. The Principles, first launched in April 2006 at the New York Stock Exchange and reviewed regularly, are voluntary and aspirational, offering a menu of possible actions for incorporating environmental, social, and corporate governance (ESG) issues into investment practices across asset classes (PRINCIPLES FOR RESPONSIBLE INVESTMENTS, 2014).

Another groundbreaking initiative was the Global Reporting Initiative's (GRI) Framework, a reporting system that enables all companies and organisations to measure, understand and communicate ESG information. The GRI Sustainability Reporting Guidelines, currently in its fourth generation, offer reporting principles, standard disclosures and an implementation manual for the preparation of sustainability reports by organisations, regardless of their size, sector or location (GLOBAL REPORTING INITIATIVE, 2014). Finally, the utmost reference concerning ESG disclosure is Bloomberg's ESG data system. Since 2009, Bloomberg Finance has uploaded company ESG data to its financial service platform, with such data being released through annual corporate sustainability reports. Bloomberg currently provides data on more than 120 ESG key performance indicators for approximately 5,000 publicly listed companies globally, and is increasing coverage every day (BLOOMBERG, 2014).

\subsection{4}

\section{The new frontiers on ESG reporting}

At the endpoint of the evolution, companies have moved beyond legal obligations and flank protection, and toward full ESG disclosure, allowing investors to better understand the intrinsic and long-term value of a company's business. Private corporations and the general public, in cooperation with state agencies, have started to voluntarily contribute expertise and resources to fill the gaps in global regulation and to resolve global public goods problems.

Nevertheless, many misconceptions remain between companies and investors on ESG factors and their financial materiality, as depicted in Figure 4. 
According to the WORLD BUSINESS COUNCIL FOR SUSTAINABLE DEVELOPMENT (2010):

[...] The depth and breadth of ESG factors are currently not fully integrated into financial valuation models because there is little direct communication between company sustainability managers and asset managers regarding ESG factors, and they do not speak the same language. The gaps in ESG communication run even deeper within individual companies and investment firms. Company sustainability managers and investor relations managers also do not speak the same language and there is little incentive to bridge the gap. Company sustainability managers are crucial to bridging knowledge and expertise on the materiality of ESG factors with investor relations managers and senior management executives on the one hand, and investors on the other hand. Similarly, asset managers that systematically integrate ESG risks and opportunities into the investment process ('ESG-inclusive asset managers') and mainstream asset managers often have the same language barrier. (WORLD BUSINESS COUNCIL FOR SUSTAINABLE DEVELOPMENT, 2010, p. 8)

Figure 4 - ESG gaps between company managers and asset managers

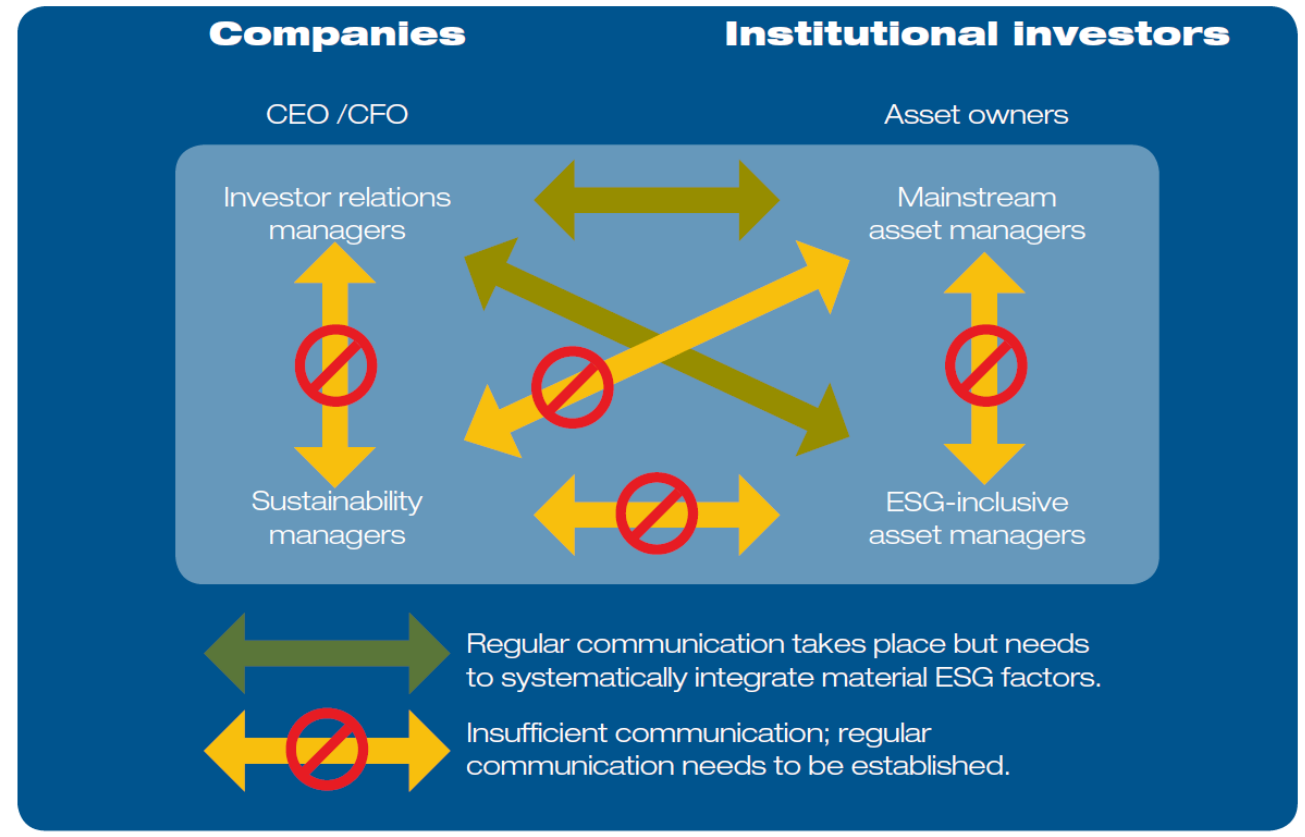

\section{Source: WORLD BUSINESS COUNCIL FOR SUSTAINABLE DEVELOPMENT (2010).}

Comparability and availability of information are also critical issues that should be further addressed. Several social indicators, for instance, "Staff 
turnover" or "Number of jobs created", are especially difficult to collect globally. A likely explanation is that the disclosure of socially relevant corporate data remains voluntary while environmental data, at least in the developed countries, must be disclosed by law. In addition, data are often not globally comparable due to regional differences in economic cycles and the typical sector rotation through them. To address these problems, large ESG databases, such as Bloomberg ESG and Thomson Reuters ESG Research data (formerly ASSET4 ESG), apart from providing relevant and systematic environmental, social and governance information, have started to calculate ESG composite disclosure scores, based on the amount and quality of information disclosed by the companies. The scoring methodology is completely transparent on their system and may vary greatly across industry sectors.

In short, although much remains to be done, the focus on ESG performance has resulted in significant improvement in terms of CSR evaluation. Furthermore, it is expected that, over time, more firms will adhere to ESG disclosure and interested parties will reach a common ground regarding ESG communication.

\section{3}

\section{CSR and Financial Performance}

\subsection{1 \\ CSR outcomes on firm performance: opposing views}

As outlined in section 1.2, from the very start of the discussions, two conflicting visions have shaped thoughts about the outcomes of CSR on firm performance: Friedman's (1970) shareholders theory, which states that a firm's only social responsibility is to increase its profits, and Freeman's (1984) stakeholders theory, whose core idea is that organisations managing their stakeholder relationships effectively will survive longer and perform better than those organisations that do not. The 'basic debate' has underlined the field of 
CSR/financial performance since its inception, with a wide range of normative, descriptive, and instrumental arguments offered on both sides.

The idea of CSR as a threat of obfuscation of businesses and government roles had already been preconized by Theodore Levitt in his article The dangers of social responsibility. According to the author, 'government's job is not business, and business's job is not government' (Levitt, 1958, p. 47). Therefore, businesspeople should not concern themselves with social responsibility. Levitt's (1958) statement, however, was not concerned with the idea of CSR at that time. Instead, he was much set on the surge of welfare policies in the post-war era, which propounded a clear distinction line between the responsibilities of business and those of the state.

Building on Levitt's (1958) argument, Friedman and Friedman (1962) alleged that a company's sole social responsibility was to pursuit maximisation of returns for their shareholders within the boundaries set by law. In a similar fashion, Friedman (1970) reasserted his position claiming that firms should use their resources and engage in activities designed to increase their profits so long as they stay within the "rules of the game".

On the other hand, consistent with the political and business climate of recent years, Freeman's (1984) stakeholder theory portrays managers as individuals who pay "simultaneous attention to the legitimate interests of all appropriate stakeholders, both in the establishment of organizational structures and general policies and in case-by-case decision making". (DONALDSON AND PRESTON, 1995, p. 67)

Although it is widely perceived that Friedman's (1970) and Freeman's (1984) approaches bear no resemblance their underlying assumption is ultimately the same, insofar both treat firms as profit-maximization organisations which are interested in improving their financial performance. The difference in these two positions is that Freeman (1984) perceived CSR as an opportunity for companies to increase their benefits whereas Friedman (1970) saw it as a threat. Therefore, the eternal debate between shareholder theory and stakeholder theory hinge primarily on whether or not firms should have safeguards on corporate behaviour.

A look into the literature shows that Friedman's (1970) vision has become one of the most heavily criticised positions in the field of CSR. This view, 
however, continues to be held by influential economists such as David Henderson, Robert Reich and others.

\subsection{2}

\section{Academic interest in nonfinancial information}

As the concept of social responsibility became popular over the years and with the conflicting views of the above-mentioned theories triggering discussions about the legitimacy and value of corporate responses to CSR concerns, a wide range of studies have investigated the relationship between CSR and financial performance (FP). The results, however, have often been contradictory, even within a given analysis, as stated by Griffin and Mahon (1997). While some authors suggest that a negative relationship holds between CSR disclosure and financial performance, such as Bromiley and Marcus (1989), Davidson et al. (1987), Davidson and Worrell (1988) and Strachan et al. (1983), others have concluded that there is indeed a positive association between these variables, as stated in Belkaoui (1976), Cowen et al. (1987), Fry et al. (1982), Spencer and Taylor (1987) and Wokutch and Spencer (1987). In addition, several investigators have found contradictory results within their own research. Freedman and Jaggi (1982), Fry and Hock (1976) and Coffey and Fryxell (1991), for instance, reported finding both positive and inconclusive relationships in their studies. The good news is that the largest number of researchers claimed to have found positive relationships between CSR and FP (Griffin and Mahon, 1997). Yet, McGuire et al. (1988) highlight that the choice of performance variables can have substantial implications for the results of a study and that researchers must carefully choose performance measures that are appropriate to the particular research question they are investigating.

\subsection{3}

Social Responsibility and Portfolio Performance 
A large portion of the studies exploring the linkages between CSR and financial performance (FP) during the 1970s and 1980s focused on one or more of the following topics: direct comparison between appropriate indicators; industryspecific control groups; non-parametric testing procedures; or statistical models. However, another body of literature emerged in the 1980s to shed light on the financial performance of the so-called "socially responsible portfolios", which incorporate ESG criteria into the investment process. The studies of Anderson and Frankle (1980) and Rudd (1981) are considered to be seminal in this field. Anderson and Frankle (1980) compared portfolios composed of the securities of socially disclosing firms to those of assets of non-disclosing firms, concluding that social disclosure has information content, which the market values in positive terms. Rudd (1981), on the other hand, investigated the financial performance of several portfolios formed on the basis of screening strategies, which basically consist of excluding companies from investments because of their involvement in certain activities deemed to be negative (negative screening), or supporting companies involved in projects with a positive social or environmental impact (positive screening). Rudd (1981) stated that those strategies bias portfolios, as they exclude securities and force concentration into other assets. Under the same reasoning, Grossman and Sharpe (1986) add that any constraint imposed on a selection of assets would only reduce or maintain investors' maximum possible utility. Diltz (1995), using the CAPM model, finds that during the time period 1989-1991 environmental and military screening strategies yielded significantly positive financial performances compared to other screenings. Guerard (1997), conversely, inferred that by using a stock selection model, socially screened portfolios do not differ from an unscreened portfolio. However, it should be stated that the sole use of screening strategies on portfolios is not a proper way to assess the relationship between ESG and financial performance, as sustainable portfolios have a clear disadvantage in terms of asset allocation compared to other types of portfolios. Instead, comparisons should be made between portfolios of equivalent systematic risk, as in Anderson and Frankle (1980).

The results of recent studies analysing synthetic portfolios of stocks are also inconclusive. Whilst Yamashita et al. (1999) and Derwall et al. (2005) reported finding a significant positive performance difference between an 
environmental high-rated and low-rated portfolio, the results of Cohen et al. (1997) suggest that there is no such difference.

\section{4}

\section{CSR and FP in Brazil}

\subsection{1}

\section{CSR practices in Brazil}

In line with a worldwide trend, Brazilian companies have made significant strides towards CSR. Brazilian entrepreneurs and executives are increasingly integrating CSR practices into their business strategies.

According to Young (2004), the positive experience in social and responsibility programmes in Brazil is mainly attributed to its long tradition of philanthropy. According to a survey conducted by the Brazilian Institute of Applied Economic Research (IPEA) in 2001 regarding businesses voluntary social initiatives, more than $60 \%$ of the companies included had invested in the social area, either directly or by donations through partnerships with nongovernmental organisations. (BRAZILIAN INSTITUTE OF APPLIED ECONOMIC RESEARCH, 2001)

Although these philanthropic characteristics are of great relevance in Brazilian society, in the past couple of decades, firms' individual actions have gradually been replaced by a corporate framework of social responsibility. Several organisations such as the Group of Institutes, Foundations and Companies (GIFE), the Corporate Citizenship Institute (ICE) and the Ethos Institute of Business and Social Responsability (Ethos Institute) have been contributing significantly to the legitimation of CSR actions as sources of solutions for social problems. The Ethos Institute, particularly, has taken on a leading role in terms of mobilising, sensitising and helping companies manage their business in a socially responsible way. Since its inception as a non-governmental organization in 1998, with only 11 member companies, the institute has garnered much attention from the general public. As a result, by mid-2004, the Ethos Institute had over 800 member companies- which together employed 1.3 million people and had aggregate 
revenues equivalent to $30 \%$ of the country's gross domestic product. (YOUNG, 2004)

The Ethos institute has also maintained several partnerships with both domestic and foreign institutions. Relevant examples include: Forum Empresa in Latin America; Business for Social Responsibility (BSR), the Rockefeller Foundation, the Harvard University, and the International Finance Corporation (IFC) in the United States; and Accountability and Sustainability in the United Kingdom. Furthermore, the institute receives financial support from member companies, such as the William and Flora Hewlett Foundation, the International Finance Corporation (IFC) and the InterAmerican Foundation (IAF) in the United States and the Interchurch Organization for Development Cooperation (ICCO), in Netherlands.

With regard to the Brazilian financial markets, much has been achieved as well. In July 2013, the Brazilian Mercantile, Futures and Stock Exchange (BM\&FBOVESPA) approved its own sustainability policy, consisting of market, environmental, social, and corporate governance initiatives. In addition, by May 2012 over $75 \%$ of the top 100 BM\&FBOVESPA companies had already been publishing CSR reports on an annual basis (BRAZILIAN MERCANTILE, FUTURES AND STOCK EXCHANGE, 2013).

CSR has also become a high profile public issue in Brazil. Brazilian consumers are quite attuned to CSR: not only have the general public started to question companies' ethics and responsibility toward society and local communities, but also they have been making investment decisions based on criteria that include ethical concerns, such as environmental protection and employee wellbeing.

In light of the extraordinary growth outlined in the previous paragraphs, CSR is already a reality in Brazil and holds immense potential for the next decades.

\subsection{2}

CSR disclosure of Brazilian firms 
In Brazil, in spite of the significant strides towards CSR, there is still no legal duty that requires companies to disclose CSR information. However, there have been several initiatives addressing this issue, such as Draft Law $1.305 \mathrm{~A} / 2003$, that outlines the standards of social responsibility of businessmen and the business companies in Brazil, and Draft Law 32/1999, which propounded the integration of Social Balance Sheets in firms' annual reports. Other one-off initiatives are: state laws 7.987/2002 in Mato Grosso (MT), 11.440/2000 in Rio Grande do Sul (RS) and 2.843/2003 in Amazonas (AM).

In addition to the legislative initiatives, it is also worth emphasising two prominent actions towards CSR disclosure in Brazil:

- the Brazilian Accounting Standard Technique 15 (NBC-T 15), of the Brazilian Federal Accounting Council (CFC), approved by CFC resolution 1.003/2004, that proposed general guidelines for firms to disclose their social and environmental performances (BRAZILIAN FEDERAL ACCOUNTING COUNCIL, 2004); and

- the Brazilian Institute of Social and Economic Analysis (IBASE) model of "Social Balance Sheet". (BRAZILIAN INSTITUTE OF SOCIAL AND ECONOMIC ANALYSIS, 2008)

IBASE balance sheets comprise information relative to CSR in six categories: company's revenue; amount spent in internal social action; amount spent on external social action; amount spent on environmental actions; indicators related to the labour force; and relevant information associated with corporate citizenship (IBASE, 2008). In addition, the institute grants firms that have acted responsibly towards society and with relation to the environment a special hallmark, the "Social Balance Seal IBASE/Betinho", so that their efforts can receive widespread attention by the stakeholders.

Both IBASE social balance sheet and NBC-T 15 have found broad acceptance among businesses and investors alike. According to Crisóstomo et al. (2014), a total of 282 Brazilian companies had reported CSR data between the years of 1996 to 2008 using the IBASE model as a standard. This number has probably increased in recent years, if one considers the fact that, by the end of 2011, the overall amount of disclosure data in Brazilian companies meeting the 
GRI standards was growing by an average of $88 \%$ annually (KPMG INTERNATIONAL, 2011).

\subsection{3 Academic output related to CSR and FP in Brazil}

Despite firms' increasing adherence to social balance sheets, much of the empirical work concerning socially responsible investments and financial market behaviour in Brazil has focused on the Brazilian Corporate Sustainability Index (ISE). Based on best practices of corporate governance, economic efficiency, social justice and environmental equilibrium, the ISE was launched in December 2005, being the fourth index of this kind in the world, following the Dow Jones Sustainability Index (DJSI), the FTSE4Good and the Johannesburg Sustainability Index (JSE). The ISE reflects the return of a portfolio composed of stocks of a maximum of 40 companies selected on the basis of sustainability guidelines. Major recent contributions regarding the ISE performance can be found in the works of Cavalcante et al. (2009), Vives and Wadha (2012), Ortas et al. (2012), Lourenço and Branco (2013) and Cunha and Samanez (2013).

Cavalcante et al. (2009) assessed the ISE financial performance over 345 trading sessions since December 2005 comparing it to the Bovespa Index (IBOVESPA) and the Brazil Index (IBrX). At first, their findings suggested no evidence of superior performance of the ISE in the period after its creation. Conversely, the authors stressed that the assets which had larger shares in the composition of the ISE portfolios performed significantly better in the period before the index's official release. Vives and Wadha (2012) examined the conditions that make for effective sustainability indices in promoting capital market development and responsible practices, concluding that the ISE plays a major role in the development of sustainability in Brazil. It does so not only by enhancing the interest of asset managers in sustainable investments, but also by serving as a reference guide for the initiation and development of sustainability practices. Ortas et al. (2012) analysed the ISE financial performance comparing it to the Bovespa Index (IBOVESPA), inferring that investing in the ISE does not result in a risk or return disadvantage in bullish market periods. However, during 
the last financial crisis, the index became riskier than its official benchmark, given that the former includes companies affected to a large extent by fluctuations, whereas the latter includes more stocks in other "sin" sectors that are not affected to the same extent.

Using the ISE as a proxy for corporate sustainability performance (CSP), Lourenço and Branco (2013), in turn, investigated the factors driving high levels of corporate sustainability performance in Brazil. They concluded that Brazilian leading CSP firms not only have a larger return on equity than non-leading corporate sustainability performance firms, but also have a lower ownership concentration and are more likely to have an international listing status than nonleading CSP firms. Finally, Cunha and Samanez (2013) assessed the ISE performance during the period from December 2005 to December 2010, comparing it to the IBOVESPA and to other BM\&FBOVESPA sectoral indexes, suggesting that although sustainable investments have presented some interesting characteristics, such as increasing liquidity and low diversifiable risk, they did not achieve satisfactory financial performance in the analysis period.

Another stream of literature that relates to the CSR-FP relationship in Brazil has focused on financial accounting studies. Important contributions on these topics can be found in the works of Macedo et al. $(2007,2012)$ and Beuren et al. (2013). Macedo et al. (2007) compared the financial and accounting performance of different Brazilian firms "deemed as socially responsible" with the market as whole using financial metrics such as profitability, indebtedness and liquidity. They did not find any significant differences in the outcomes of the two groups. Macedo et al. (2012), in turn, resorted to information about profitability, profit margin, asset turnover, liquidity, indebtness and capitalization to compare the accounting and financial performance of socially and environmentally responsible companies and others without this profile in the Brazilian electric distribution sector during the years of 2005, 2006 and 2007. The comparison between the average performances of these two groups, using nonparametric tests, showed that socially and environmentally responsible companies had superior accounting and financial performances from the statistical standpoint. Beuren et al. (2013), on the other hand, investigated the relationship between the level of environmental disclosure and the economic performance of certain publicly- 
traded companies during the years of 2005-2008 and concluded that the association, if any, was not yet clearly defined.

In this work, the relationship between socially responsible investing and financial performance is re-examined using a different approach in the Brazilian electric sector, in which firms' social responsibilities are evaluated within a multidimensional framework considering information from their annual social reports. We expect that our findings will contribute to a better understanding of these issues in contemporary Brazil. 


\section{3 \\ Methodology}

\section{1 \\ Data Envelopment Analysis}

The first step of this work consists of selecting, among all Brazilian publicly traded electric companies, those with the best ESG practices. Moreover, we also consider different groups of companies, ranked according to their performances in terms of CSR. To do so, we make use of a multidimensional approach, commonly referred to as Data Envelopment Analysis (DEA), in which different ESG criteria serve as the bases of comparison. DEA is a nonparametric based approach that measures relative efficiencies of a homogenous set of Decision Making Units (DMUs). It builds upon the concept of the best practice frontier, first introduced by Farrell (1957), in which the relative performance of all utilities in the sample can be compared. The methodology includes a multidimensional framework for relative performance evaluation in which efficiency scores, ranging from 0 to 1 , are assigned to each DMU by comparing them with the best practice units. DMUs use the same types of inputs and produce the same types of outputs, differing, however, in the number of inputs required to produce a certain number of outputs (GONÇALVES et al., 2013).

Given its empirical orientation and the absence of a need for the numerous a priori assumptions that accompany parametric approaches, DEA has been widely applicated in many different contexts. It has also opened up possibilities for use in cases which have been resistant to other approaches because of the complex (often unknown) nature of the relations between the multiple inputs and multiple outputs involved in DMUs.

\subsection{1}

\section{Efficiency measurement concepts}


The underlying theory of the best practice frontier concept goes back to the 1950s, building upon the works of Debreu (1951) and Koopmans (1951). Debreu (1951) proposed that an index could be constructed so as to measure the distance by which the economy deviates from the optimal situation. His ideias at that time, however, left scope for a wide variety of interpretive approaches. Koopmans (1951), in turn, first defined technical efficiency as the capability of a firm to maximise outputs for given inputs. However, Koopmans' definition offered no guidance regarding the degree of inefficiency.

The above-mentioned issues were addressed by Farrell (1957), who suggested measuring inefficiency as the observed deviation from a frontier isoquant. Therefore, relative performance of all utilities in a sample could be compared. In addition, Farrel (1957) proposed that the efficiency of a firm consists of two components: a technical efficiency, which reflects the ability of a firm to obtain maximal output from a given set of inputs, and an allocative efficiency, which demonstrates a firm's capacity to use the inputs in optimal proportions, given respective prices. Both measures combine to provide a measure of total economic efficiency. This terminology conforms with that which has been used most often in recent academic outputs.

\subsubsection{1 \\ Input-oriented measures}

Farrell (1957) illustrated his ideas through a simple framework involving firms which use two inputs (namely $x_{1}$ and $x_{2}$ ) to produce a single output $(\mathrm{y})$, under the assumption of constant returns to scale (CRS), whereby an increase in inputs results in a proportionate increase in output levels. This allowed for technology representation using a unit isoquant.

Considering that the production function of a fully efficient firm is known in practice, the measurement of technical efficiency is straightforward, as depicted in Figure 5. If a given DMU uses quantities of inputs, defined by the point $\mathrm{P}$, to produce a unit of output, the technical inefficiency of that DMU, in absolute terms, is represented by the distance QP, which indicates the amount by which all inputs could be proportionally reduced without a reduction in output. 
This inefficiency could also be expressed in relative terms by the ratio QP/OP, which represents the percentage by which all inputs could be reduced.

Under such circumstances, the technical efficiency $\left(\mathrm{TE}_{i}\right)$ of a DMU can be defined as

$$
\mathrm{TE}_{i}=O Q /_{O P}=1-Q P / O P
$$

A value of one indicates the DMU is fully technically efficient, e. g. the firm situated in point $\mathrm{Q}$, which lies in the efficient isoquant.

Figure 5 - Technical and allocative efficiencies

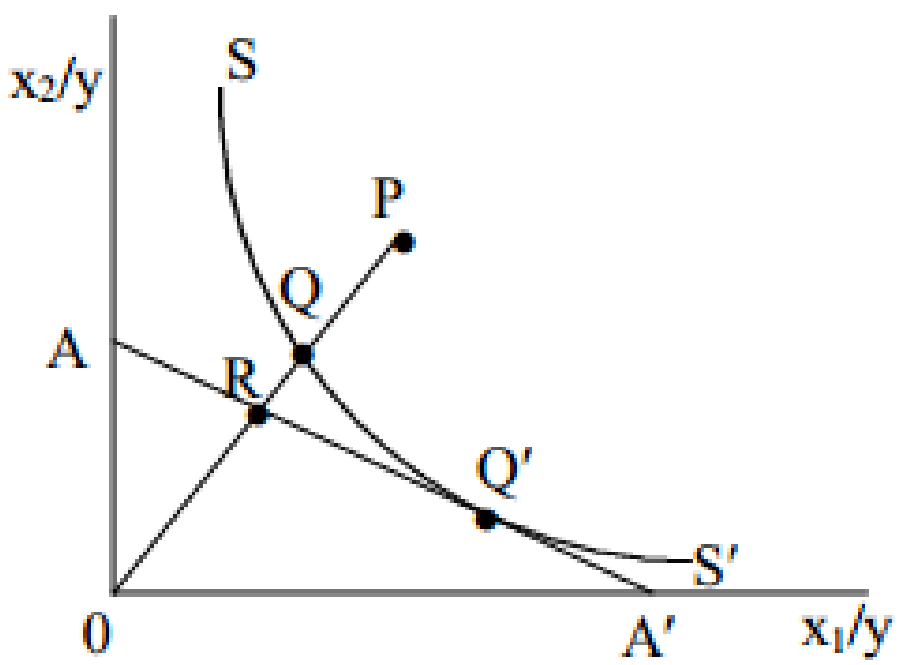

Source: Adapted from Coelli et al. (2005, p. 52).

If the input price ratio is also known, as depicted by the line $\mathrm{AA}^{\prime}$ in Figure, one may also calculate the allocative efficiency. The allocative efficiency $\left(\mathrm{AE}_{i}\right)$ of a $\mathrm{DMU}$ operating at $\mathrm{P}$, for instance, is given by the ratio

$$
\mathrm{AE}_{i}=O R / O Q
$$

since the distance RQ represents the reduction in production costs that would occur if production occurred at the allocatively (and technically) efficient point Q'.

The total economic efficiency $\left(\mathrm{EE}_{i}\right)$ is thus defined as 


$$
\mathrm{EE}_{i}=O R / O P
$$

and RP can be interpreted in terms of cost reduction. It is worth highlighting that the product of technical and allocative efficiency provides the overall economic efficiency and that all measures are bounded by zero and one:

$$
\mathrm{TE}_{i} \times \mathrm{AE}_{i}=O Q / O P \times O R / O Q=O R / O P=\mathrm{EE}_{i}
$$

The above-mentioned efficiency measures assume that the production function of the fully efficient firm is known. In practice, however, the efficient isoquant must be estimated from the sample data. To address this issue, Farrell (1957) suggested the use of either a parametric function, such as the Cobb-Douglas form, or a nonparametric piecewise-linear convex isoquant to fit the data, as illustrated in Figure 6. Irrespective of the choice, the curves should be constructed in a way that no observed DMU lies to the left or below it.

Figure 6 - Piecewise-linear convex isoquant

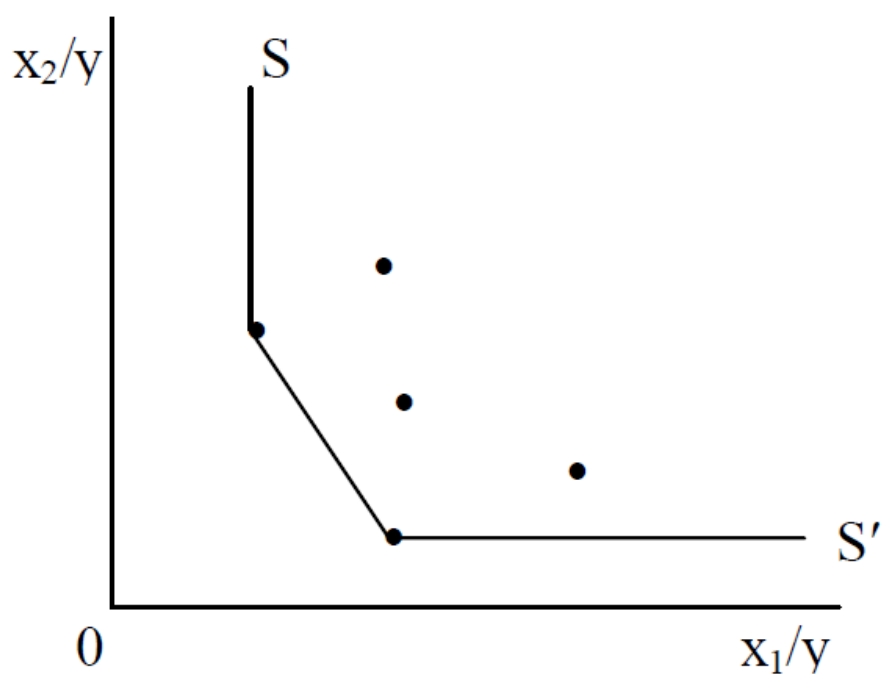

Source: Author's own.

\subsubsection{2}

\section{Output-oriented measures}

In the previous section, the input-oriented technical efficiency measure addressed the question: "By how much can input quantities be proportionately 
reduced without changing the output quantities produced?" Alternatively, one may be interested in determining by how much outputs can be proportionately expanded without changing the input quantities. In such case, an output-oriented technical efficiency is used.

The difference between the input and output-oriented measures can be illustrated using a simple example involving one input and one output. This is illustrated in Figure 7(a), under the assumption of a decreasing returns to scale (DRS) technology, represented by $\mathrm{f}(\mathrm{x})$. Considering an inefficient DMU operating at point $\mathrm{P}$, the Farrell input-oriented measure of $\mathrm{TE}$ equals the ratio $\mathrm{AB} / \mathrm{AP}$, while the output-oriented TE would be CP/CD.

Figure 7 - Input and output-oriented technical efficiency measures and returns to scale

(a) DRS

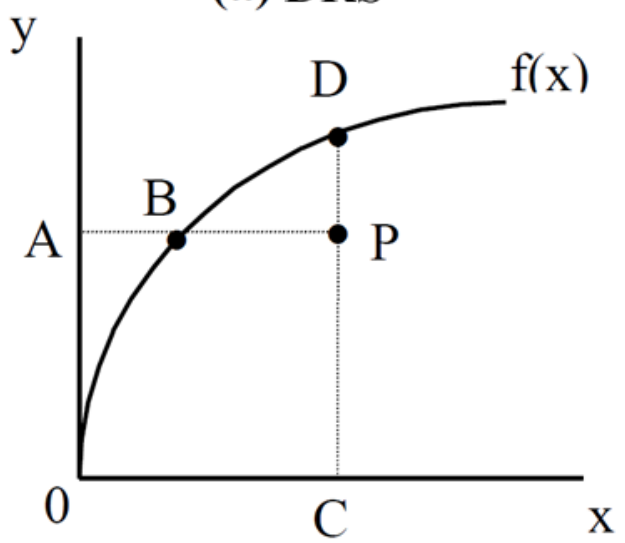

(b) CRS

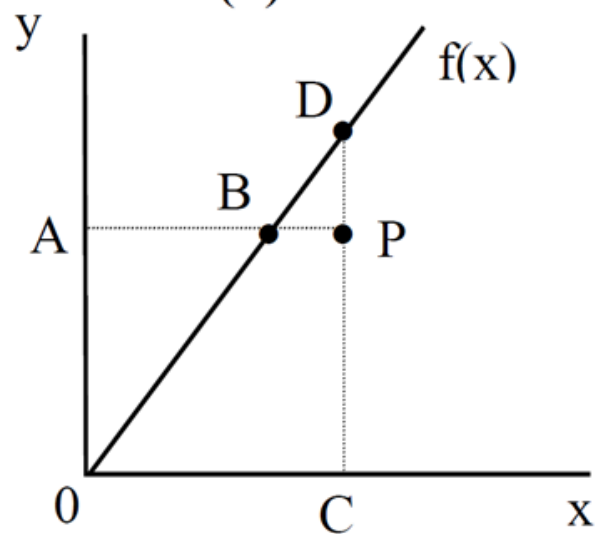

Source: Adapted from Coelli et al. (2005, p. 55).

According to Färe and Lovell (1978), the input and output-oriented measures will only provide equivalent measures of TE if the constant returns to scale (CRS) assumption holds true. This is the case for Figure 7(b), where AB/AP $=\mathrm{CP} / \mathrm{CD}$, regardless of the $\mathrm{P}$ point chosen .

One may also refer to output-oriented measures by considering the case where production involves two outputs $\left(y_{1}\right.$ and $\left.y_{2}\right)$ and a single input $\left(x_{1}\right)$. Again, if one assumes CRS, the technology can be represented by a unit production curve in two dimensions. This example is outlined in Figure 8, where the ZZ' curve stands for the unit production possibility curve and point A corresponds to an 
inefficient DMU. Since in an output-oriented problem $\mathrm{ZZ}$ ' represents the upper bound of production possibilities, the inefficient point A lies below this curve.

Figure 8 - Technical and allocative efficiencies from an output orientation

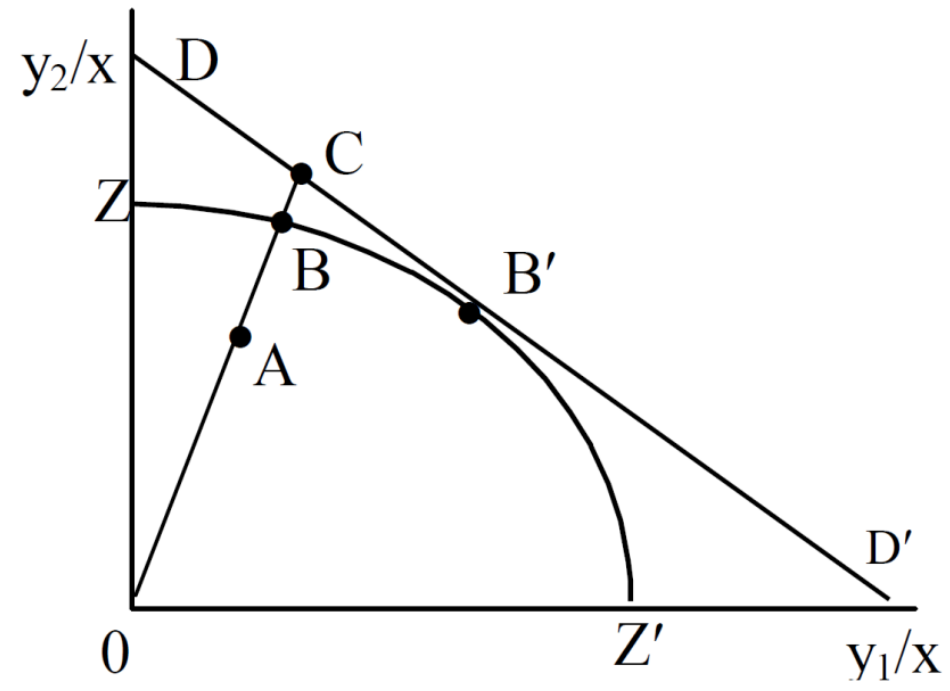

Source: Adapted from Coelli et al. (2005, p. 55).

Still regarding Figure 8, the technical inefficiency of DMU A is represented, in absolute terms, by the distance $\mathrm{AB}$. That is, $\mathrm{AB}$ equals the amount by which outputs could be increased without requiring extra inputs. Accordingly, the output-oriented technical efficiency can be defined as

$$
\mathrm{TE}_{\mathrm{o}}=O A /_{O B}=1-A B / O B
$$

If the price information is available as well, one can draw the isorevenue curve DD' and define the allocative efficiency as

$$
\mathrm{AE}_{\mathrm{o}}=O B / O C
$$

The allocative efficiency in the output-oriented problem has a revenue increasing interpretation, similar to the cost reducing interpretation of allocative inefficiency in the input-oriented case.

The overall economic efficiency $\left(\mathrm{EE}_{\mathrm{o}}\right)$ in the output-oriented problem is thus defined as 


$$
\mathrm{EE}_{\mathrm{o}}=O A /_{O C}=O A /_{O B} \times O B / O C=\mathrm{TE}_{\mathrm{o}} \times \mathrm{AE}_{\mathrm{o}}
$$

Finally, it is worth highlighting that, irrespective of the problem orientation, all efficiency measures previously defined are measured along a ray from the origin to the observed production point. Thus, they hold the relation proportions of inputs (or outputs) constant. One advantage of these radial efficiency measures is that they are units invariant inasmuch as changing the units of measurement will not change the value of the efficiency measure. In other words, opting for measuring quantity of labour in person hours in lieu of person years does not lead to different efficiency results. This does not occur in nonradial measures, where changing the units of measurement result in the identification of a different "nearest" point, as explained in Coelli et al. (2005).

\subsubsection{3 \\ Further concepts in DEA}

Before proceeding to the DEA models, two basic concepts in DEA are worth emphasising:

Definition 1: (Efficiency - Extended Pareto-Koopmans Definition): The performance of a DMU is efficient if and only if none of its inputs or outputs can be improved without worsening some of its other inputs or outputs.

In practice, however, the theoretically possible levels of efficiency are not be known. The preceding definition is therefore replaced by emphasising its uses with only the information that is empirically available as in the following definition:

Definition 2: (Relative Efficiency): A DMU is to be rated as fully (100\%) efficient on the basis of available evidence if and only if the performances of other DMUs does not show that some of its inputs or outputs can be improved without worsening some of its other inputs or outputs. (COOPER et al., 2011)

According to the above-mentioned definitions, DEA does not require the assignment of predetermined weights to reflect the relative importance of the different inputs or outputs . Moreover, in contrast to parametric approaches, there 
is also no need for recourse for an explicit functional form. This basic kind of efficiency, referred to as "technical efficiency" in economics can, however, be extended to other kinds of efficiency when data such as prices, unit costs, etc., are available for use in DEA.

In light of the above, and given their enormous versatility, DEA models have been quickly recognised as an excellent and easily used tool for modeling operational processes for performance evaluations.

\subsection{2}

DEA models

Since its genesis until today, DEA has been markedly developed in both theoretical innovation and practical applications. Nevertheless, the conventional Constant Returns to Scale (CRS) and Variable Returns to Scale (VRS) models are two prevailing assumptions in the literature. They are briefly described in the following subsections.

\subsubsection{1 The CCR/CRS model}

The first model using Farrell's (1957) piecewise-linear convex hull approach to frontier estimation was introduced by Charnes, Cooper and Rhodes and marked the birth of DEA. (CHARNES et al., 1978)

Charnes et al. (1978) proposed an input-oriented model assuming constant returns to scale (CRS) in which the relative technical eficiencies of decision making units (DMUs) could be calculated using a linear programming model. The key purpose of the CCR/CRS ${ }^{2}$ model, according to Cooper et al. (2011), was to 'float' a piecewise linear surface to rest on top of the sample observations in lieu of trying to fit a regression plane through the center of the data as in statistical regression, for example.

\footnotetext{
${ }^{2}$ The CCR model proposed by Charnes et al. (1978) is also known by the authors initials, CCR (Charnes, Cooper and Rhodes).
} 
Charnes et al. (1978) first introduced the CCR/CRS model via the ratio form. According to their formulation, assuming that there are $n$ DMUs in a reference set $(j=1,2, \ldots, o, \ldots n)$, each with $m$ inputs $x_{i j}(i=1,2, \ldots, o, \ldots m)$ and $s$ outputs $y_{r j}(r=1,2, \ldots, o, \ldots s)$, the relative efficiency score of DMU $o$, i.e., the observed DMU, is obtained by solving the following programming model $^{3}$ :

$$
\operatorname{Maxh}_{\mathrm{o}(u, v)}=\frac{\sum_{r=1}^{s} u_{r} y_{r o}}{\sum_{i=1}^{m} v_{i} x_{i o}}
$$

s.t.

$$
\begin{gathered}
\frac{\sum_{r=1}^{s} u_{r} y_{r j}}{\sum_{i=1}^{m} v_{i} x_{i j}} \leq 1 \\
j=1,2, \ldots, o, \ldots n \\
u_{r}, v_{i} \geq 0, \quad \forall i, r
\end{gathered}
$$

One problem with this particular ratio formulation is that it yields an infinite number of solutions inasmuch as if $\left(u^{*}, v^{*}\right)$ is optimal, then $\left(\alpha u^{*}, \alpha v^{*}\right)$ is also optimal for $\alpha>0$. However, the transformation developed by Charnes and Cooper (1962) for linear fractional programming selects a representative solution, i.e., the solution $(u, v)$ for which $\sum_{i=1}^{m} v_{i} x_{i o}=1$, and yields the equivalent linear programming problem in which the change of variables from $(u, v)$ to $(\mu, v)$ is a result of the Charnes-Cooper transformation:

$$
\operatorname{Max} \mathrm{z}=\sum_{r=1}^{s} \mu_{r} y_{r o}
$$

s.t.

$$
\begin{gathered}
\sum_{i=1}^{m} v_{i} x_{i o}=1 \\
\sum_{r=1}^{s} \mu_{r} y_{r j}-\sum_{i=1}^{m} v_{i} x_{i j} \leq 0 \\
\mu_{r}, v_{i} \geq 0, \quad \forall i, r
\end{gathered}
$$

\footnotetext{
${ }^{3}$ Remark: A fully rigorous development would replace $\mu_{r}, v_{i} \geq 0$ with $\frac{u_{r}}{\sum_{i=1}^{m} v_{i} x_{i o}}, \frac{v_{i}}{\sum_{i=1}^{m} v_{i} x_{i o}} \geq \varepsilon \geq$ 0 , where $\varepsilon$ is a positive non-Archimedean infinitesimal. This condition guarantees that solutions will be positive in these variables. An interested reader is referred to Arnold et al. (1998).
} 
The above-mentioned formulation is commonly known as the multiplier form of the Charnes et al. (1978) model, since the unknowns are the virtual multipliers of outputs and inputs - the factor weights $\mu_{r}$ e $v_{i}$, respectively. Using the duality in linear programming, one can derive an equivalent envelopment form of the CCR/CRS model:

$$
\operatorname{Min} \theta_{(\theta, \lambda)}
$$

s.t.

$$
\begin{gathered}
\sum_{j=1}^{n} x_{i j} \lambda_{j} \leq \theta x_{i o} \\
\sum_{j=1}^{n} y_{r j} \lambda_{j} \geq y_{r o} \\
\lambda_{j} \geq 0 \\
i=1, \ldots, m \quad r=1, \ldots, s \quad j=1, \ldots, n
\end{gathered}
$$

where $\theta$ is a scalar and $\lambda$ is a $\mathrm{N} \mathrm{x} 1$ vector of constants. By virtue of the dual theorem of linear programming, $\mathrm{z}^{*}=\theta^{*}$. Thus, either forms may be used. However, because the envelopment form involves fewer constraints than the previous model, it is generally preferred for practical applications. This last form is also equivalent to the model propounded by Farrell (1957) in the sense that it will satisfy $\theta \leq 1$, with a value of 1 indicating a point on the frontier and hence a technically efficient DMU.

According to Cooper et al. (2011), in the economics portion of the DEA literature, the above-mentioned model is said to conform to the assumption of "strong disposal" because it ignores the presence of non-zero slacks. From the operations research perspective, this is referred to as "weak efficiency."

\subsubsection{1}

\section{A footnote on slacks}

A particular issue concerning the DEA approach to frontier estimation is the possibility of slacks values when measuring technical efficiencies. The problem arises because of the sections of the piecewise piecewise-linear hull 
which run parallel to the axes. This is illustrated in Figure 9, where the DMUs using input combinations $\mathrm{C}$ and D are the two efficient DMUs which define the frontier, and DMUs A and B are inefficient.

Figure 9 - Efficiency measurement and input slacks

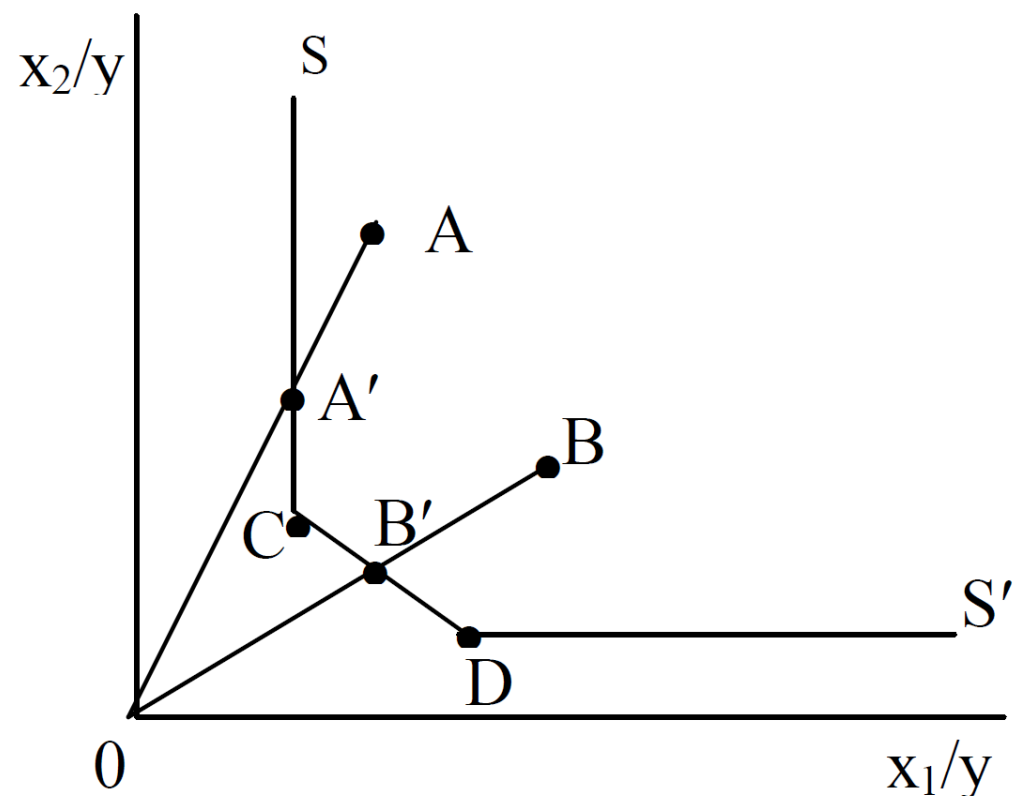

Source: Adapted from Coelli et al. (2005, p. 165).

The Farrell (1957) measure of technical efficiency defines the efficiency of DMUs $\mathrm{A}$ and $\mathrm{B}$ as $\mathrm{OA}^{\prime} / \mathrm{OA}$ and $\mathrm{OB}^{\prime} / \mathrm{OB}$, respectively. Nevertheless, it is indeed doubtful whether the point $\mathrm{A}^{\prime}$ is an efficient point since one could reduce the amount of input $x_{2}$ - by the amount CA' - and still produce the same output. This issue is generally addressed as input slack or input excess in the literature. In addition, if one considers a case involving more inputs and/or multiple outputs, the diagrams are no longer as simple, and output slacks may also occur.

In view of the above, it could be alleged that both the Farrell measure of technical efficiency $(\theta)$ and any non-zero input or output slacks should be reported to provide an accurate indication of technical efficiency of a DMU in DEA. It is important to stress that, for the $o$-th DMU, the output slacks will be equal to zero only if $\sum_{j=1}^{n} y_{r j} \lambda_{j}-y_{r o}=0$, while the input slacks will be equal to zero only if $\theta x_{i o}-$ $\sum_{j=1}^{n} x_{i j} \lambda_{j}=0$ (for the given optimal values of $\theta$ and $\lambda$ ). 
In Figure 9, the identification of the input slack associated with the point $\mathrm{A}^{\prime}$ is straightforward: $\mathrm{CA}^{\prime}$ of input $x_{2}$. However, in cases where there are more inputs and outputs, the identification of the "nearest" efficient frontier point (such as $\mathrm{C}$ ), and hence the subsequent calculation of slacks, is not a trivial task. Some authors, such as Ali and Seiford (1993) have suggested the solution of a secondstage linear programming problem to move to an efficient frontier point by maximising the sum of slacks required to move from an inefficient point to a Koopmans-efficient frontier point:

$$
\operatorname{Max} \sum_{i=1}^{m} s_{i}^{-}+\sum_{r=1}^{s} s_{r}^{+}
$$

s.t.

$$
\begin{array}{cc}
\sum_{j=1}^{n} x_{i j} \lambda_{j}+s_{i}^{-}=\theta^{*} x_{i o} & i=1, \ldots, m \\
\sum_{j=1}^{n} y_{r j} \lambda_{j}-s_{r}^{+}=y_{r o} & r=1, \ldots, s \\
\lambda_{j}, s_{i}^{-}, s_{r}^{+} \geq 0 & \forall i, j, r
\end{array}
$$

where $s_{i}^{-}$and $s_{r}^{+}$respectively stand for the input and output slacks of the $o$-th DMU and do not affect the optimal $\theta^{*}$ which is determined from equation 10 . Under such circumstances, two other definitions arise:

Definition 3: (DEA Efficiency): The performance of a DMU is fully (100\%) efficient if and only if both (i) $\theta^{*}=1$ and (ii) all slacks $s_{i}^{-}=s_{r}^{+}=0$.

Definition 4: (Weakly DEA Efficient): The performance of a DMU is weakly efficient if (i) $\theta^{*}=1$ but (ii) $s_{i}^{-} \neq 0$ and/or $s_{r}^{+} \neq 0$ for some $i$ and $r$ in some alternate optima.

The preceding development depicted in equations 10 and 11 amounts to solving the following problem in two steps:

$$
\operatorname{Min} \theta-\varepsilon\left(\sum_{i=1}^{m} s_{i}^{-}+\sum_{r=1}^{s} s_{r}^{+}\right)
$$

s.t.

$$
\sum_{j=1}^{n} x_{i j} \lambda_{j}+s_{i}^{-}=\theta^{*} x_{i o} \quad i=1, \ldots, m
$$




$$
\begin{array}{cc}
\sum_{j=1}^{n} y_{r j} \lambda_{j}-s_{r}^{+}=y_{r o} & r=1, \ldots, s \\
\lambda_{j}, s_{i}^{-}, s_{r}^{+} \geq 0 & \forall i, j, r
\end{array}
$$

Two major issues arise, however, with the second stage linear programming (LP). The first is the fact that the sum of slacks is being maximised instead of minimised. Thus, the solution will not identify the nearest efficient point but the furthest efficient point. The second major problem is that the LP is no longer invariant to units of measurement. To circumvent these issues, many authors suggest to simply solve the first-stage LP to obtain the Farrell radial technical efficiencies $(\theta s)$ and ignore the slacks completely. An alternative would be to report both radial technical efficiency scores and the residual slacks of each DMU, which may be calculated as follows:

$$
\begin{gathered}
I S_{o}=\theta x_{i o}-\sum_{j=1}^{n} x_{i j} \lambda_{j}=\theta x_{i o}-\boldsymbol{X} \lambda \\
O S_{o}=-y_{r o}+\sum_{j=1}^{n} y_{r j} \lambda_{j}=-y_{r o}+\boldsymbol{Y} \lambda
\end{gathered}
$$

where $I S_{o}$ and $O S_{o}$ respectively stand for input and output slack of the $o$-th DMU - analogous to $s_{i}^{-}$and $s_{r}^{+}$in equations 11 and 12 - and the letters in bold represent the vectors of inputs $(\boldsymbol{X})$, outputs $(\boldsymbol{Y})$ and constants $(\boldsymbol{\lambda})$.

This approach, however, is not without problems due to the fact that residual slacks may not always provide all (Koopmans) slacks and thus may not always identify the nearest (Koopmans) efficient point for each DMU.

In spite of the above-mentioned issues, according to Coelli et al. (2005), the importance of slacks may be overstated. If an infinite sample size were available or if an alternative frontier construction method was used (e. g. using a smooth function), the slack issue would cease to exist. In addition, following Ferrier and Lovell (1990), it can be argued that slacks are essentiallty allocative inefficiency and, therefore, an analysis of technical efficiency can reasonably concentrate upon the radial efficiency score provided in the first stage of DEA. 


\subsubsection{2}

\section{Output-oriented CCR/CRS}

The models described in equations (9) and (10) correspond respectively to the multiplier and envelopment forms of the original CCR/CRS input-oriented model. In an input-oriented DEA model, the aim is to determine by how much inputs can be proportionately reduced without changing the output quantities that are produced. However, one may be interested in determining by how much outputs can be proportionately expanded without changing the input quantities. Therefore, disregarding the possibility of slacks, an output-oriented version of the CCR/CRS model can be defined as

$$
\operatorname{Min} \mathrm{q}=\sum_{i=1}^{m} v_{i} x_{i o}
$$

s.t.

$$
\begin{gathered}
\sum_{r=1}^{s} \mu_{r} y_{r o}=1 \\
\sum_{r=1}^{s} \mu_{r} y_{r j}-\sum_{i=1}^{m} v_{i} x_{i j} \leq 0 \\
\mu_{r}, v_{i} \geq 0, \quad \forall i, r
\end{gathered}
$$

or, alternately, in the envelopment form,

$$
\operatorname{Max} \Phi_{(\Phi, \lambda)}
$$

s.t.

$$
\begin{gathered}
\sum_{j=1}^{n} x_{i j} \lambda_{j} \leq x_{i o} \\
\sum_{j=1}^{n} y_{r j} \lambda_{j} \geq \Phi y_{r o} \\
\lambda_{j} \geq 0 \\
i=1, \ldots, m \quad r=1, \ldots, s \quad j=1, \ldots, n
\end{gathered}
$$




\subsubsection{2 The BCC/VRS model}

The models described in section 3.1.2.1 consider constant returns to scale, whereby an increase in inputs results in a proportionate increase in output levels. This assumption is appropriate when all DMUs are operating at an optimal scale. Nevertheless, depending on the problem specification, one can expect that an increase in inputs may not result in a proportional change in outputs. Imperfect competitions, government regulations, constraints on finance are common examples that may cause a firm/DMU not to be operating at optimal scale.

According to Coelli et al. (2005), should a firm exhibit different types of returns to scale in different ranges of output, the CRS specification will result in measures of technical efficiencies (TE) that are confounded by scale efficiencies (SE). To circumvent this problem, Banker et al. (1984) proposed the BCC/VRS model under the assumption of variable returns to scale. Once again, the abbreviations relate to the authors' initials (Banker, Charnes and Cooper) and the corresponding returns to scale. The BCC model was originally developed by adding a convexity restriction to the CCR formulation, thus generating a variable returns to scale (VRS) frontier. To do so, in the multiplier form of the CCR model, a new variable is added to the objective function: $u_{o}$, if input-oriented, or $v_{o}$, if output-oriented. The multiplier (dual) forms of input and output-oriented BCC/VRS model can be written as below:

$$
\operatorname{Maxz}=\sum_{r=1}^{s} \mu_{r} y_{r o}+u_{o}
$$

s.t.

$$
\begin{gathered}
\sum_{i=1}^{m} v_{i} x_{i o}=1 \\
\sum_{r=1}^{s} \mu_{r} y_{r j}+u_{* o}-\sum_{i=1}^{m} v_{i} x_{i j} \leq 0 \\
\mu_{r}, v_{i} \geq 0, \forall i, r ; \quad u_{* o} \text { unconstrained in sign }
\end{gathered}
$$




$$
\operatorname{Min} \mathrm{q}=\sum_{\mathrm{i}=1}^{\mathrm{m}} v_{i} x_{i o}+v_{o}
$$

s.t.

$$
\begin{gathered}
\sum_{r=1}^{s} \mu_{r} y_{r o}=1 \\
\sum_{r=1}^{s} \mu_{r} y_{r j}-\sum_{i=1}^{m} v_{i} x_{i j}+v_{* o} \leq 0 \\
\mu_{r}, v_{i} \geq 0, \quad \forall i, r ; \quad v_{* o} \text { unconstrained in sign }
\end{gathered}
$$

(output-oriented)

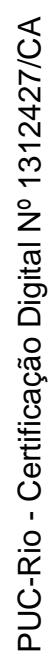

As depicted in Figure 10, three ranges can be distinguished within the BCC efficient frontier: increasing returns to scale (IRS), constant returns to scale (CRS) and decreasing returns to scale (DRS). With increasing (decreasing) returns to scale, an increase in input levels leads to a higher (lower) increase in output levels.

Figure 10 - Efficiency measurement and input slacks

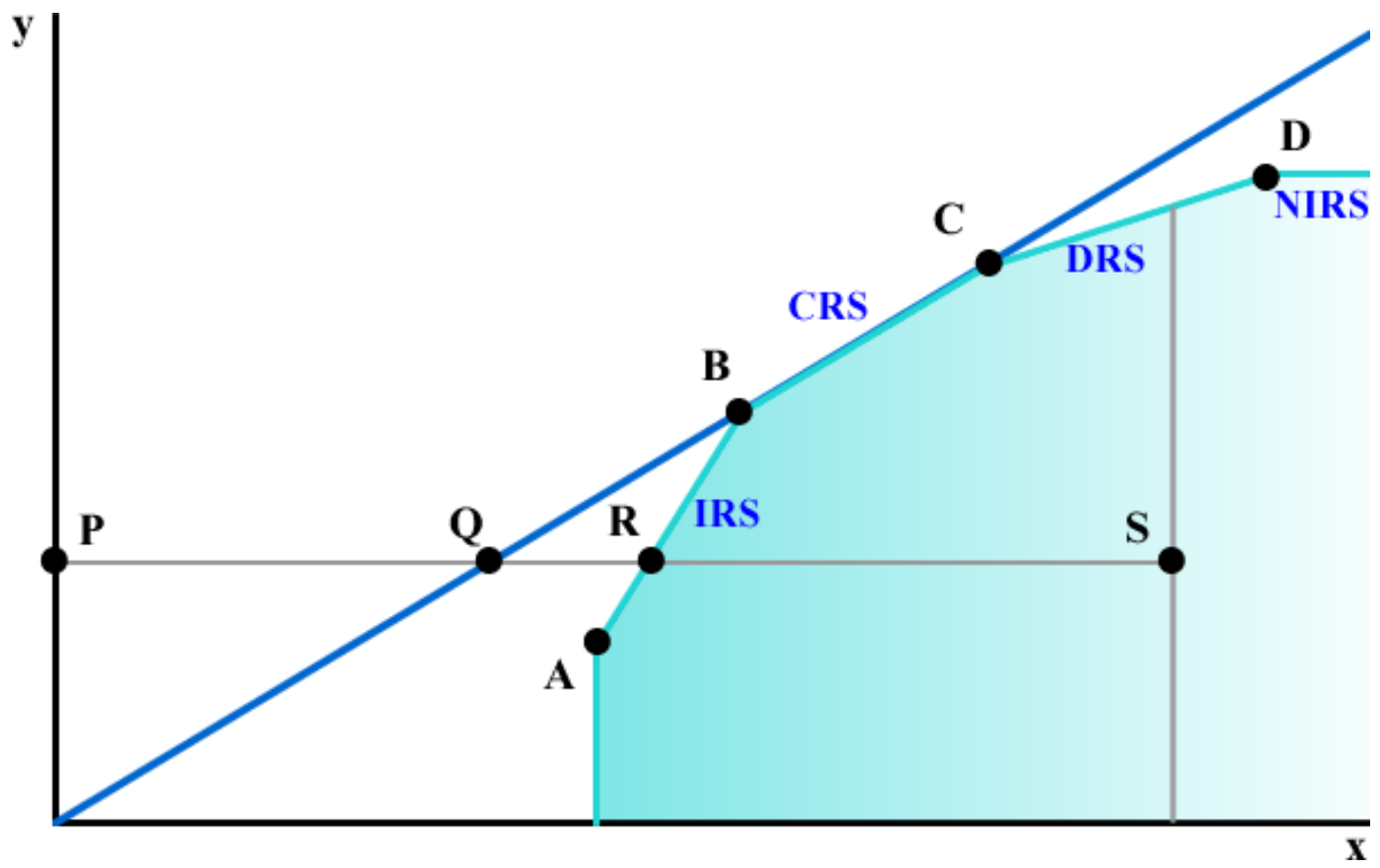

Source: Adapted from Banker et al. (2011, p. 44). 
It should be stressed, though, that in the literature of classical economics, returns to scale (RTS) have only been typically defined for single-output situations, such as the one illustrated in Figure 10. In view of this, Banker et al. (1984) and Banker and Thrall (1992) extended the RTS concept from the singleoutput case to multiple-output cases using DEA. Considering $\left(\hat{x}_{o}, \hat{y}_{o}\right)$ as the coordinates of the point on the efficiency frontier which is obtained in the evaluation of $\mathrm{DMU}_{\mathrm{o}}$ via the solution to (16) or (17), the following conditions identify the situation for RTS for the multiplier forms of the BCC model:

(i) IRS prevail at $\left(\hat{x}_{o}, \hat{y}_{o}\right)$ if and only if $u_{o}^{*}>0$ (if input-oriented) $/ v_{*_{o}}<$ 0 (if output-oriented) for all optimal solutions;

(ii) DRS prevail at $\left(\hat{x}_{o}, \hat{y}_{o}\right)$ if and only if $u_{o}^{*}<0$ (if input-oriented) / $v_{* o}>0$ (if input-oriented) for all optimal solutions;

(iii) CRS prevail at $\left(\hat{x}_{o}, \hat{y}_{o}\right)$ if and only if $u_{o}^{*}=0 / v_{* o}=0$ for at least one optimal solution.

Following the same reasoning, accounting for variable returns to scale when using the envelopment (primal) form of the BCC/VRS model can be done by adding the convexity constraint $\sum_{j=1}^{n} \lambda_{j}=1$ in equations 10 (if input-oriented) or 15 (if output-oriented), as follows:

$$
\operatorname{Min} \theta_{(\theta, \lambda)}
$$

s.t.

$$
\begin{gathered}
\sum_{j=1}^{n} x_{i j} \lambda_{j} \leq \theta x_{i o} \\
\sum_{j=1}^{n} y_{r j} \lambda_{j} \geq y_{r o} \\
\sum_{j=1}^{n} \lambda_{j}=1 \\
\lambda_{j} \geq 0 \\
i=1, \ldots, m \quad r=1, \ldots, s \quad j=1, \ldots, n \\
\text { (input-oriented) }
\end{gathered}
$$


$\operatorname{Max} \Phi_{(\Phi, \lambda)}$

s.t.

$$
\begin{gathered}
\sum_{j=1}^{n} x_{i j} \lambda_{j} \leq x_{i o} \\
\sum_{j=1}^{n} y_{r j} \lambda_{j} \geq \Phi y_{r o} \\
\sum_{j=1}^{n} \lambda_{j}=1 \\
\lambda_{j} \geq 0 \\
i=1, \ldots, m \quad r=1, \ldots, s \quad j=1, \ldots, n
\end{gathered}
$$

(output-oriented)

According to Coelli et al. (2005), the convexity constraint ensures that an inefficient DMU is only benchmarked agains firms of a similar size. In other words, its projected point on the DEA frontier is a convex combination of observed firms. In contrast, for CRS DEA, a DMU may be benchmarked against firms that are substantially larger (smaller) than itself. In this instance, for the input-oriented version, the $\lambda$-weights sum to a value less than (greater than) one.

\subsubsection{3}

\section{CCR vs BCC and scale efficiencies}

The BCC/VRS approach forms a convex hull of intersect facets ${ }^{4}$ that envelope the data points more tightly than the CCR/CRS conical hull. Hence, the technical efficiency (TE) scores in the former are always greater than or equal to those obtained in the latter. For instance, considering DMUS in Figure 10, the BCC and CRS technical efficiency measures are calculated as follows:

$$
\begin{aligned}
& \left(\mathrm{TE}_{\mathrm{BCC}}\right) \mathrm{DMU}_{\mathrm{s}}=P R / P S \\
& \left(\mathrm{TE}_{\mathrm{CCR}}\right) \mathrm{DMU}_{\mathrm{s}}=P Q / P S
\end{aligned}
$$

\footnotetext{
${ }^{4}$ As a general rule, the use of term "planes" is correct for the three-dimensional case. However, when more dimensions come to play, i.e., when the number of inputs + outputs exceeds three, the term "facet" is more appropriate.
} 
The difference between these two measures is addressed as scale inefficiency. In other words, the TE scores obtained from the CCR approach can be decomposed into two components, one due to pure technical efficiency $\left(\mathrm{TE}_{\mathrm{BCC}}\right)$ and one due to scale efficiency (SE), as follows:

$$
\left(\mathrm{TE}_{\mathrm{CCR}}\right) \mathrm{DMU}_{\mathrm{s}}=\left(\mathrm{TE}_{\mathrm{BCC}}\right) \mathrm{DMU}_{\mathrm{s}} \times(\mathrm{SE}) \mathrm{DMU}_{\mathrm{s}}
$$

where

$$
(\mathrm{SE}) \mathrm{DMU}_{\mathrm{s}}=P Q / P R
$$

It should be stressed, though, that this measure of scale efficiency does not indicate if the DMU is operating in an area of increasing or decreasing returns to scale. To address this issue, one may run an additional DEA problem with nonincreasing returns to scale (NIRS) imposed. To do so, the convexity constraint $\sum_{j=1}^{n} \lambda_{j}=1$ in the envelopment forms of the BCC/VRS model is replaced by $\sum_{j=1}^{n} \lambda_{j} \leq 1$. Thus, the nature of the scale inefficiencies for a particular DMU can be determined upon comparison of the NIRS TE and VRS TE scores. If they are unequal, then increasing returns to scale prevail for that DMU. On the other hand, if the NIRS and VRS TEs present the same score values, then decreasing returns to scale apply.

As a final remark, it worth highlighting that the constraint $\sum_{j=1}^{n} \lambda_{j} \leq 1$ ensures that the observed DMU is not benchmarked against firms that are substantially larger than it, but may be compared with firms smaller than it.

\subsection{3}

\section{CSR evaluation using ESG metadata}

As previously outlined in the introduction and in section 3.1, the first step of this work is to propose a coherent set of metrics to assess Corporate Social Responsibility (CSR) in the Brazilian electric sector. In this regard, given the rise of environmental, social and corporate governance performance (ESG) indicators worldwide, providing both quantitative and measurable CSR information, and the 
constant struggles of the ESG platforms to provide clear and concise ESG composite scores, in this work, we opt to evaluate CSR based on ESG metadata. In other words, to address our CSR evaluation problem, we make use of the composite scores calculated by the ESG databases according the information disclosed on firms' annual social reports (see sections 2.2.2 and 2.2.3 for further details).

In this work, particularly, the chosen ESG composite disclosure scores are calculated by Bloomberg ESG, the utmost reference concerning ESG disclosure (see section 2.2.3), and are principally based on the Global Reporting Initiative (GRI) standards. Despite disclosure and consistency challenges, ESG performance has become so sufficiently widespread that its analysis is valuable to long-term investors across all sectors, giving companies a compelling reason to increase their ESG data collection and reporting efforts. (GOLDMAN SACHS, 2009)

After gathering the ESG metadata, a DEA model is called for, in which basically the three different ESG criteria serve as the basis of output comparisons among the Brazilian electric companies. Nevertheless, in spite of their significant improvement in terms of CSR evaluation throughout the years, ESG disclosure scores are still more concerned with capturing the breadth of reporting rather than the quality of reported information. In addition, an evaluation purely based on ESG composite scores is not reliable, inasmuch as it does not account for the size of the firms and the amount of capital that they are willing to compromise in socially responsible activities. To address these issues, we also include the ratio between a firm's net annual revenue (NAR) and its total expenditure in environmental activities (Totex) as the input of the selected DEA model. In other words, should concerns towards the environment be embedded in a company's culture, its NAR/Totex ratio will probably be lower than the average for its competitors. As a result, given that inputs in DEA models follow "the less the better rule", the more capital a company is willing to compromise in socially responsible acitivies, the higher its DEA efficiency score.

In short, for each year of the analysis, a DEA model is run using the following inputs and outputs: 
- Inputs: Ratio between net annual revenue and total expenditure in environmental activities (NAR/Totex) - Input 01.

- Outputs: Environmental Disclosure Score (EDS) - output 01; Social Disclosure Score (SDS) - output 02; and Corporate Governance Disclosure Score (CGDS) - output 03.

With regard to the nature of returns to scale, according to Hollingsworth and Smith (2003), to ensure that comparisons among DMUs are made by interpolation only, ruling out unfeasible extrapolations, the BCC specification is required whenever data are in the form of ratios rather than absolute numbers, as in this case (NAR/Totex ratio). In addition, it can be argued that items on corporate social reports may be fairly heterogeneous and sometimes weakly related and, for this reason, that some requirements are easier to meet than others. Finally, difficulties in increasing ESG performance may vary greatly across firms, depending on their activities. For these reasons, a BCC/VRS model was used to measure the productive efficiency of decision making units.

As for the problem orientation, in this work, it is assumed that producing more outputs, i.e., having higher ESG disclosure scores, is more essential than reducing the input variable. There are several reasons that support this argument: firstly, there is only one input in the model and it only address one specific point of the ESG factors, while ESG disclosure scores encompass almost all companies' efforts to become more socially responsible; secondly, there is a certain limit to which a company can reduce its NAR/Totex ratio, while ESG disclosure scores may vary greatly throughout the years depending on a company's budget; and finally, emphasising ESG performance indicators allows firms to separate assignments strategies more effectively rather than by focusing on reducing the NAR/Totex ratio. On these grounds, an output-oriented version is preferred for modelling ESG performance. 


\section{2 Portfolio Formation}

\subsection{1 Firm groups}

After assessing companies' ESG performances based on their DEA efficiency values, three distinct groups are formed in each year of the analysis period: a first group comprising firms with the best ESG practices, i.e., with the highest DEA efficiencies (mostly above 90\%); a second group including companies with the lowest efficiency values; and a last group which encompasses all firms that did not produce any social reports during the years of the analysis. This latter group is important to check whether releasing social information has any difference at all on a firm's performance. In addition, by restricting our analysis to only electric firms disclosing social information, not only would we reduce the significance of our results, but we would also lose information from the electric sector as a whole. Upon completion of this process, we proceed to portfolio formation within each firm group.

\subsection{2 Classes of portfolios}

Four different portfolios are formed for each firm group, which makes a total of 12 portfolios per year of the analysis. In the first class of portfolios (Portfolios A), the weights of each firm are proportional to their DEA efficiencies within each group, except for the third group, where all firms participate with the same weights on the portfolio formation. In the second case (Portfolios B), all firms within each group receive the same weights, i.e., the process is identical to the third group exception of the first case. Portfolios $\mathrm{C}$, in turn, are global minimum-variance (GMVs) portfolios, which aim to find the asset combination offering the lowest possible risk levels within each firm group - in line with Markowitz (1952) Modern Portfolio Theory (see section 3.2.4.1 for further details) - and Portfolios D are maximum Sharpe portfolios, whose objective is to 
find optimal weights that maximise the Sharpe ratio - a performance index proposed by Sharpe (1966) measuring the risk-adjusted excess return of an asset or a portfolio over its benchmark (see section 3.2.5 for further details).

Additionally, for the last two cases (Portfolios C and D), we also impose a special restriction in which all firms are forced to participate with a minimum percentage of $2,5 \%$ on each group portfolio formation. This not only contributes to the reduction of the portfolio's diversifiable risk but also allows for a better understanding of the relationship between ESG factors and portfolio financial performance, as restricted portfolios better represent their group overall performance.

\subsection{3}

\section{Risk and expected return of portfolios}

In this work, the standard deviation based on historical stock returns is used to gauge the risk of individual assets and portfolios. According to Samanez (2007), the variance of a portfolio's return is the expected value of the squared deviation of the actual return from the portfolio's expected return. The actual return of a portfolio $p$ of $N$ assets can be computed as follows:

$$
R_{p}=\sum_{i=1}^{N} W_{i} \times R_{i}
$$

where $W_{i}$ and $R_{i}$ correspond respectively to the weights and returns of individual assets within the portfolio. The expected return of a portfolio, in turn, is the expected value of equation (24):

$$
\begin{aligned}
\mathrm{E}\left(R_{p}\right)=\overline{R_{p}} & =\mathrm{E}\left(\sum_{i=1}^{N} W_{i} \times R_{i}\right)=\sum_{i=1}^{N} W_{i} \times \mathrm{E}\left(R_{i}\right) \\
& =\sum_{i=1}^{N} W_{i} \times \bar{R}_{\iota}
\end{aligned}
$$

Hence, the variance of a portfolio can be stated as follows: 


$$
\begin{gathered}
\sigma_{p}^{2}=\mathrm{E}\left(R_{p}-\overline{R_{p}}\right)^{2}=\mathrm{E}\left(\sum_{i=1}^{N} W_{i} \times R_{i}-\sum_{i=1}^{N} W_{i} \times \bar{R}_{\iota}\right)^{2} \\
=E\left(W_{i} \times \sum_{i=1}^{N}\left(R_{i}-\bar{R}_{i}\right)\right)^{2} \\
=E\left(\sum_{i=1}^{N} W_{i}^{2}\left(R_{i}-\bar{R}_{i}\right)^{2}+\sum_{i=1}^{N} \sum_{\substack{j=1 \\
i \neq j}}^{N} W_{i} W_{j}\left(R_{i}-\bar{R}_{i}\right)\left(R_{j}-\bar{R}_{j}\right)\right)
\end{gathered}
$$

Thus, for a portfolio of $N$ assets:

$$
\sigma_{p}^{2}=\sum_{i=1}^{N} W_{i}^{2} \sigma_{i}^{2}+\sum_{i=1}^{N} \sum_{\substack{j=1 \\ j \neq i}}^{N} W_{i} W_{j} \rho_{i, j} \sigma_{i} \sigma_{j}
$$

where $\rho_{i, j}$ denotes the correlation between assets $i$ and $j$ while $\sigma_{i}$ and $\sigma_{j}$ represent their standard deviations, respectively.

\subsubsection{1}

\section{Diversifiable and systematic risks}

In matrix form, equation (27) can be written as below:

$$
\begin{gathered}
\sigma_{p}^{2}=\left(\begin{array}{llll}
W_{1} W_{2} & \cdots & W_{N}
\end{array}\right)\left(\begin{array}{cccc}
\sigma_{1}^{2} & \sigma_{12} & \cdots & \sigma_{1 N} \\
\sigma_{21} & \sigma_{2}^{2} & \cdots & \sigma_{2 N} \\
\vdots & \vdots & \ddots & \vdots \\
\sigma_{N 1} & \sigma_{N 2} & \cdots & \sigma_{N}^{2}
\end{array}\right)\left(\begin{array}{c}
W_{1} \\
W_{2} \\
\vdots \\
W_{N}
\end{array}\right) \\
\sigma_{p}^{2}=\boldsymbol{W}^{\prime} \boldsymbol{\sigma}_{i, j} \boldsymbol{W}
\end{gathered}
$$

where $\boldsymbol{W}$ is the vector of assets' weights within the portfolio, $\boldsymbol{W}^{\prime}$ is the transposed form of $\boldsymbol{W}$ and $\boldsymbol{\sigma}_{i, j}$ corresponds to the portfolio's variance-covariance matrix. Note that $\sigma_{1}{ }^{2}$ stands for the variance of asset 1 , which is nothing but the covariance of the asset with itself. By definition, the covariance between two assets, say $i$ and $j$, is defined as follows: 


$$
\begin{aligned}
& \sigma_{i j}=E\left[\left(R_{i}-\bar{R}_{i}\right)\left(R_{j}-\bar{R}_{j}\right)\right] \\
& =\sum_{i=1}^{N} \sum_{j=1}^{T} \frac{\left(R_{i}-\bar{R}_{i}\right)\left(R_{j}-\bar{R}_{j}\right)}{T}
\end{aligned}
$$

where $R_{i}$ and $R_{j}$ are the returns of assets $i$ and $j$ at observation $\mathrm{T}$, and $\bar{R}_{i}$ and $\bar{R}_{j}$ are their expected returns.

The $\boldsymbol{\sigma}_{i, j}$ variance-covariance matrix of a a portfolio of $N$ assets is an $\mathrm{N} \mathrm{x}$ $\mathrm{N}$ quadratic matrix whose main diagonal contains the variances of assets 1 to $\mathrm{N}$ and the other elements represent the covariances of assets 1 to N. In this regard, two other concepts may be defined: the mean covariance $\left(\bar{\sigma}_{i j}\right)$ and the mean variance $\left(\bar{\sigma}_{i}^{2}\right)$ of the assets returns within a portfolio. These are computed as follows:

$$
\begin{gathered}
\bar{\sigma}_{i j}=\sum_{\substack{i=1 \\
\text { if } \\
i \neq j}}^{N} \sum_{i j} \frac{1}{N^{2}-N}=\sum_{\substack { i=1 \\
\begin{subarray}{c}{j=1 \\
i \neq j{ i = 1 \\
\begin{subarray} { c } { j = 1 \\
i \neq j } }\end{subarray}}^{N} \sigma_{i j}\left(\frac{1}{N}\right)\left(\frac{1}{N-1}\right) \\
\bar{\sigma}_{i}^{2}=\sum_{i=1}^{N} \frac{1}{N} \sigma_{i}^{2}
\end{gathered}
$$

In addition, supposing an equally weighted portfolio, i.e.,

$$
W_{i}=\frac{1}{N} \forall N
$$

and substituting equations (31), (32) and (33) into equation (27), we obtain:

$$
\begin{aligned}
\sigma_{p}^{2} & =\sum_{i=1}^{N}\left(\frac{1}{N}\right)^{2} \sigma_{i}^{2}+\sum_{i=1}^{N} \sum_{\substack{j=1 \\
i \neq j}}^{N}\left(\frac{1}{N}\right)\left(\frac{1}{N}\right) \sigma_{i j} \\
& =\frac{1}{N} \sum_{i=1}^{N} \frac{1}{N} \sigma_{i}^{2}+\left(\frac{1}{N}\right) \sum_{i=1}^{N} \sum_{\substack{j=1 \\
i \neq j}}^{N}\left(\frac{1}{N}\right) \sigma_{i j}
\end{aligned}
$$




$$
\begin{gathered}
=\frac{1}{N} \bar{\sigma}_{i}^{2}+\left(\frac{N-1}{N}\right) \sum_{i=1}^{N} \sum_{\substack{j=1 \\
i \neq j}}^{N} \frac{1}{N(N-1)} \sigma_{i j} \\
=\frac{1}{N} \bar{\sigma}_{i}^{2}+\left(\frac{N-1}{N}\right) \bar{\sigma}_{i j}
\end{gathered}
$$

As the number of assets within a portfolio tends to infinity, the first part of equation (34) tends to zero and the second part tends to the mean covariance of the assets returns. Hence:

$$
\sigma_{p}^{2}=\lim _{N \rightarrow \infty} \underbrace{\left[\frac{1}{N} \bar{\sigma}_{i}^{2}\right.}_{0}+(\underbrace{\frac{N-1}{N}}_{1}) \bar{\sigma}_{i j}]=\bar{\sigma}_{i j}
$$

In light of the above, there is a part of the total risk that can be reduced or eliminated by holding a portfolio of assets that are uncorrelated, i.e., through diversification. This risk is commonly addressed as diversifiable risk, also known as unsystematic, idiosyncratic, specific or residual risk. In turn, the second term of equation (35) represents the risk inherent to the entire market or an entire market segment. Since this systematic risk, also known as undiversifiable, volatility or market risk, affects the overall market and not just a particular stock or industry, it is both unpredictable and impossible to completely avoid. Therefore, it cannot be mitigated through diversification, only through hedging or by using the right asset allocation strategy.

Figure 11 illustrates the behaviour of the above-mentioned risk types according to the number of assets within a portfolio. 
Figure 11 - The components of total investment risk

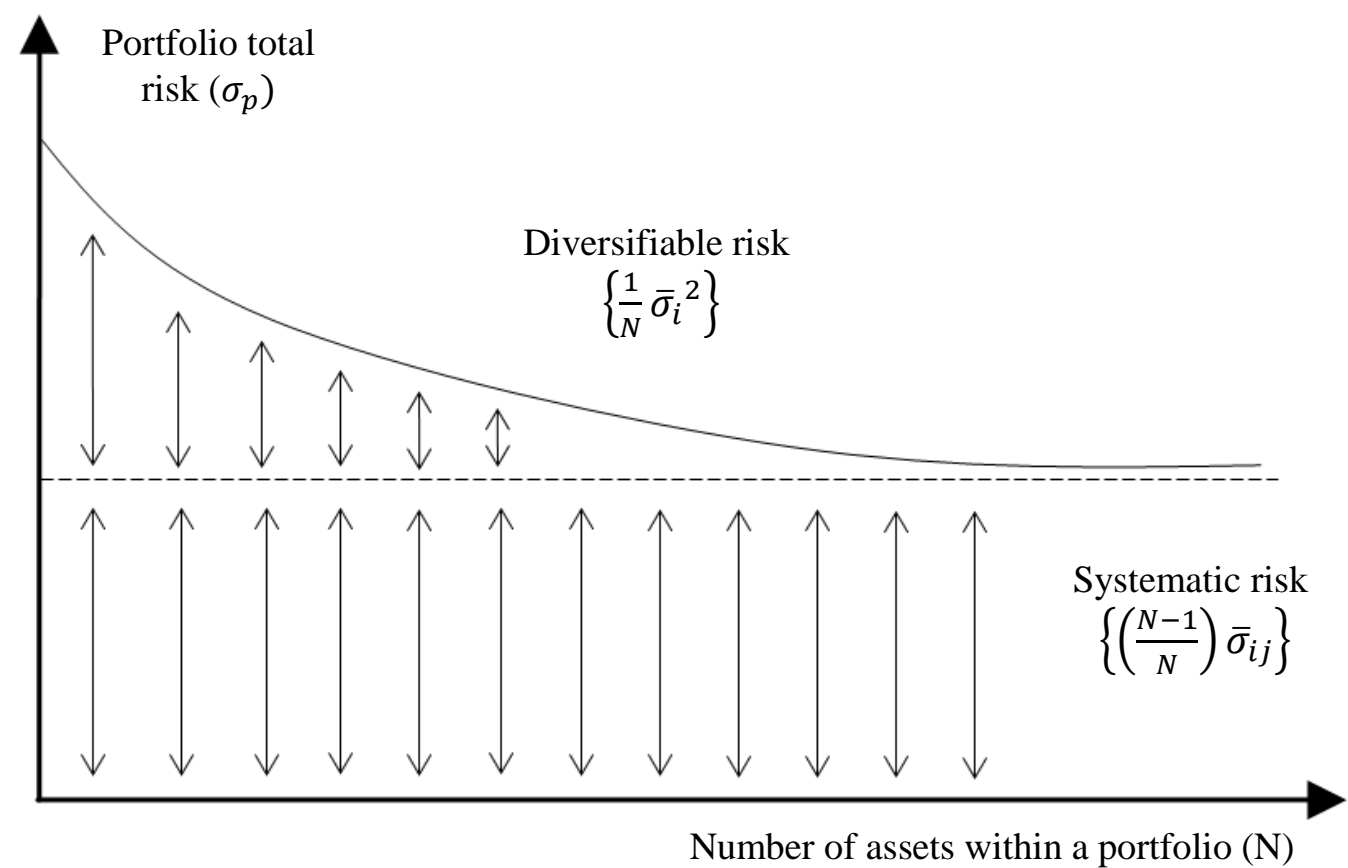

Source: Author's own.

As a general rule, a portfolio comprising 10-15 assets eliminates the diversifiable risk for the most part.

\subsection{4 \\ Minimum variance portfolios}

As outlined in section 3.2.2, Portfolios $\mathrm{C}$ are global minimum-variance (GMVs) portfolios in the sense that their optimal weights are defined according to a linear programming model whose main objective is to find the lowest possible risk levels. In other words, the minimum variance portfolio is a particular combination of securities that will result in the least possible variance.

\subsubsection{1 \\ Modern portfolio theory}

Although the composition of a GMV portfolio depends only on the covariance matrix of stock returns, its fundamentals date back to Markowitz's 
(1952) modern portfolio theory (MPT), a mean-variance approach that proposes, by carefully choosing the proportions of various assets, to maximise a portfolio expected return for a given amount of risk, or equivalently minimise the risk for a certain level of expected return.

With the advent of the MPT, Markowitz (1952) set forth a new concept that involved considering the portfolio as a whole, whereas previously investors had been interested in securities on an individual basis. Even though it is common knowledge that the Markowitz mean-variance model has empirical drawbacks, it is undoubtedly the most widely used model in both academic and real-world applications.

In brief terms, the Markowitz (1952) model is based on the following assumptions:

- investors construct their portfolios in order to maximise the expected utility of their terminal wealth;

- their utility function is an increasing function of their wealth and they are risk averse inasmuch as they do not derive extra utility for taking higher risks;

- their final choice is based only on the first two moments of the random distribution of their wealth: the expectation and the variance. Since the final wealth is determined by the return on the investment, it is thus equivalent to basing it on the expected portfolio return and the variance of the portfolio return. By this token, the expected utility of an individual's terminal wealth is a function of the mean and the variance of the portfolio return. Portfolios that result from maximising the investor's utility are, by definition, efficient portfolios.

In light of the above-mentioned circumstances, Markowitz (1952) developed a mathematical portfolio selection model under the assumption that 
investors have a quadratic utility function ${ }^{5}$. In its simplest form, the model can be written as follows:

$$
\operatorname{Min} \sigma_{\mathrm{p}}^{2}=\boldsymbol{W}^{\prime} \boldsymbol{\sigma}_{\boldsymbol{i}, \boldsymbol{j}} \boldsymbol{W}
$$

s.t.

$$
\begin{gathered}
R_{p}=\sum_{i=1}^{N} W_{i} \times R_{i} \\
\sum_{i=1}^{N} W_{i}=1 \\
0 \leq W_{i} \leq 1, \quad i=1, \ldots, n
\end{gathered}
$$

The above-mentioned model enables investors to find the composition of all the portfolios that corresponds to the efficient frontier, which offers the best possible expected level of return in a portfolio for its level of risk (here gauged by the standard deviation of the portfolio's return). Investing is thus a tradeoff between risk and expected return, since the choice of a particular point on the efficient frontier is a function of the utility of each investor and the investor's aversion to risk. The investor chooses a portfolio that is at the point of tangent between the efficient frontier and the indifference curve. The portfolio is obtained by maximising the expectation of a function of his wealth's utility. Figure 12 illustrates an example of an efficient frontier . Every possible combination of the risky assets, without including any holdings of the risk-free asset, can be plotted in the region of the risk-expected return space generally referred to as feasible set or opportunity set. The efficient frontier (or efficient set) is the portion of the opportunity set that offers the highest expected return for any given level of risk, and therefore lies at the top of this hyperbolic region. It should be stressed that all the points on the efficient frontier can be obtained with the help of two efficient portfolios only. Every portfolio on the efficient frontier can be written in the form of a linear combination of two distinct portfolios that are situated on the frontier.

\footnotetext{
${ }^{5}$ Quadratic utility functions are often chosen because their expected utility is only expressed as a function of the portfolio's mean and variance. Another alternative would be to assume that the assets returns are normally distributed thoroughly. This assumption, however, is only respected over a short time horizon.
} 
This result is known as Black's theorem. The interested reader is referred to Black (1972).

Figure 12 - Investment opportunity set of attainable portfolios

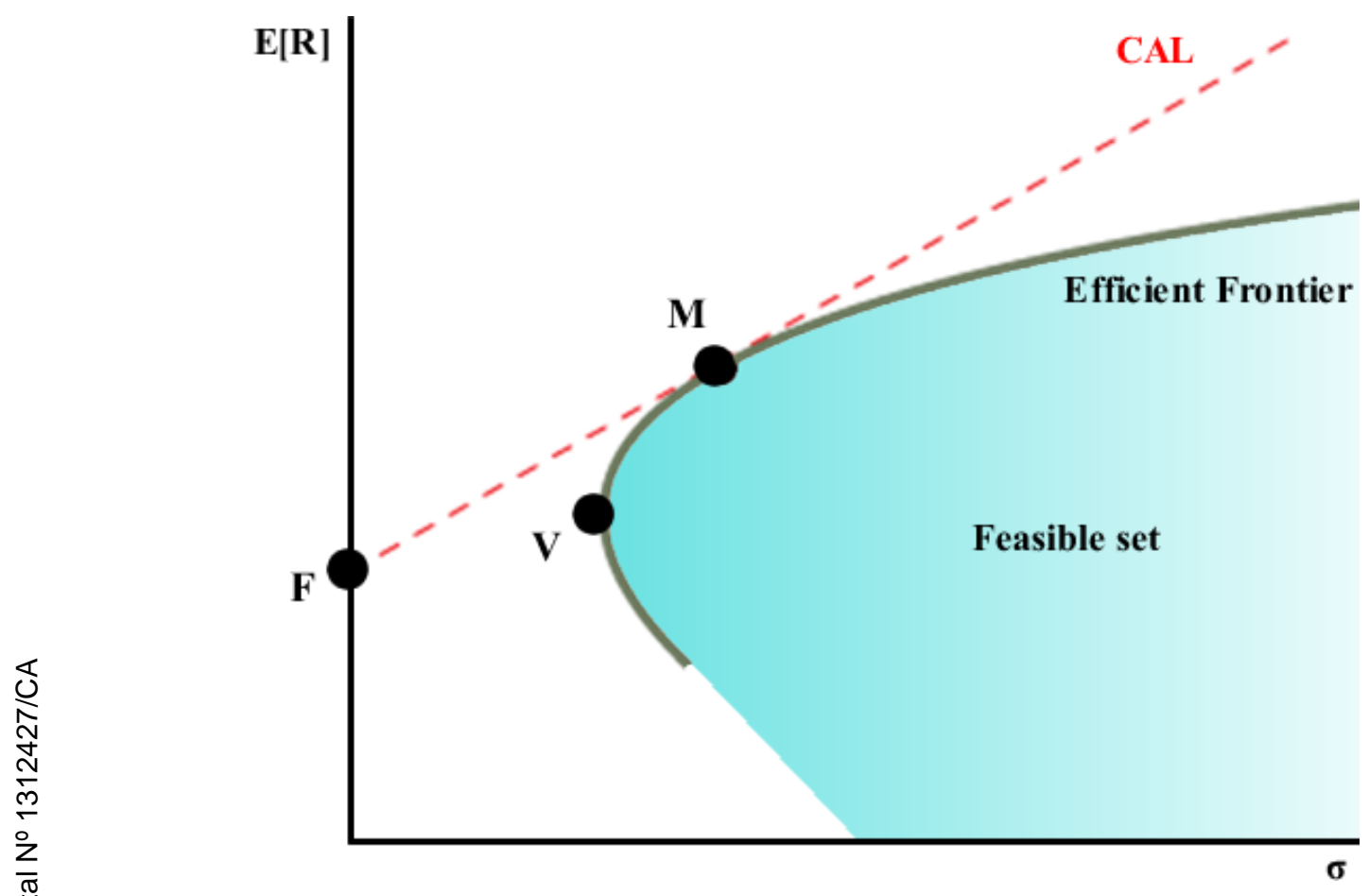

Source: Author's own.

The red positively-sloped curve, in turn, is the capital allocation line (CAL), sometimes also referred to as capital market line (CML). It is the tangent line drawn from the point of the risk-free asset $\left(R_{f}\right)$ to the feasible region for risky assets. The CAL/CML is considered to be superior to the efficient frontier since it takes into account the inclusion of a risk-free asset in the portfolio and can be represented by the following equation:

$$
E\left(R_{c}\right)=R_{f}+\sigma_{c} \frac{E\left(R_{p}\right)-R_{f}}{\sigma_{p}}
$$

where $C$ is a combination of portfolio $p$ and the risk-free asset. The tangency point $\mathrm{M}$ represents the market portfolio, which results from a combination composed entirely of the risky asset, the market. It is sometimes also addressed as the most efficient portfolio or the super-efficient portfolio in the sense that it lies on both the CAL and Efficient Frontier and that all points along the CAL have superior 
risk-return profiles to any other portfolio on the efficient frontier, except for portfolio M.

Finally, point $\mathrm{V}$ stands for the global minimum-variance (GMV) portfolio, which represents the combination of assets which offers the lowest return variance for a given covariance matrix. In other words, unlike other portfolios on the efficient frontier, the only required optimisation inputs are covariances (correlations) between the assets and their volatilities, as follows:

$$
\operatorname{Min} \sigma_{\mathrm{p}}^{2}=\boldsymbol{W}^{\prime} \boldsymbol{\sigma}_{\boldsymbol{i}, \boldsymbol{j}} \boldsymbol{W}
$$

s.t.

$$
\begin{gathered}
\sum_{i=1}^{N} W_{i}=1 \\
0 \leq W_{i} \leq 1, \quad i=1, \ldots, n
\end{gathered}
$$

\subsubsection{2 \\ Constrained global minimum-variance portfolios}

Many empirical studies argue that an investment in the GMV portfolio often yields better out-of-sample results than other portfolios in the efficient frontier (JORION, 1992; CHOPRA AND ZIEMBA, 1993; JAGANNATHAN AND MA, 2003). This is mainly attributed to the fact that the only required optimisation inputs are correlations between the assets and their volatilities. Therefore, GMV portfolios, unlike other combinations of assets, are appealing because they do not incur estimation risks resulting from expected returns (AMENC AND MARTELLINI, 2002).

Even so, despite the reasonable idea of avoiding expected returns estimation, two major issues come into play when opting for GMVs portfolios. First, since they have only the objective of lowering risk, rather than aiming to optimise the risk/reward ratio, their optimisation leads to a pronounced concentration in low volatility assets at the expense of exploiting correlation properties, resulting in an undiversified portfolio (CLARKE et al., 2011). Second, 
from an ex-ante perspective, minimum variance portfolios are not optimal portfolios and they will be dominated in the long-run by a combination of the risk/reward optimal portfolio (tangency portfolio) with cash.

In light of the above, in lieu of using GMV portfolios directly, to compare the different firm groups within a minimum-variance framework, a special restriction is imposed in which all firms are forced to participate with a minimum percentage of $2,5 \%$ on each group portfolio formation. This not only contributes to the reduction of the portfolio's diversifiable risk but also allows for a better understanding of the relationship between ESG factors and portfolio financial performance, as restricted portfolios better represent their group overall performance. The restricted minimum-variance portfolio (Portfolio C) is computed as follows:

$$
\operatorname{Min} \sigma_{\mathrm{p}}^{2}=\boldsymbol{W}^{\prime} \boldsymbol{\sigma}_{\boldsymbol{i}, \boldsymbol{j}} \boldsymbol{W}
$$

s.t.

$$
\begin{gathered}
\sum_{i=1}^{N} W_{i}=1 \\
0,025 \leq W_{i} \leq 1, \quad i=1, \ldots, n
\end{gathered}
$$

\subsection{5 Maximum Sharpe portfolios}

As previously outlined, in spite of being suitable at first glance for investors who wish to load on low-risk or "defensive" stocks, GMV portfolios are prone to be outperformed in the long-run by a combination of the risk/reward optimal portfolio (tangency portfolio) with cash. In view of this, apart from considering a constrained version of the GMV portfolios in the analysis (Portfolios C), we also compare firm ESG groups within another class of portfolios: the constrained Maximum Sharpe portfolios (Portfolios D).

The goal of a Maximum Sharpe portfolio, or Maximum Sharpe ratio (MShR) portfolio, is to find optimal weights that maximise the Sharpe ratio - a performance index proposed by Sharpe (1966) measuring the risk-adjusted excess return of an asset or a portfolio over its benchmark. In this perspective, if we opt 
to represent the benchmark by the risk-free rate, the MShR portfolio corresponds to the tangency portfolio (market portfolio - M) illustrated in Figure 12. Hence, in line with the Modern Portfolio Theory, the MShR porfolio can be computed as follows:

$$
\operatorname{Max} \operatorname{ShR}=\frac{\mathrm{R}_{\mathrm{p}}-\mathrm{R}_{\mathrm{b}}}{\sigma_{\mathrm{p}}}
$$

s.t.

$$
\begin{gathered}
R_{p}=\sum_{i=1}^{N} W_{i} \times R_{i} \\
\sum_{i=1}^{N} W_{i}=1 \\
0 \leq W_{i} \leq 1, \quad i=1, \ldots, n
\end{gathered}
$$

where $R_{b}$ is the selected benchmark. In contrast to the GMV portfolio, maximum Sharpe ratio strategies do not refrain from estimating expected returns. While this results in additional estimation risk, the potential for harnessing the diversification benefits from distinguishing between high and low return stocks may bring increased outperformance in the long-run. Even so, this does not ensure that all assets will be included in the composition of the MShR portofolio. Therefore, since we do not want to lose track of our main objective, which is to compare different firm groups from an ESG performance perspective, the same GMV constraint is imposed to the MShR portfolios in our analysis. By this token, Portfolios D are formed as follows:

$$
\operatorname{Max} \operatorname{ShR}=\frac{\mathrm{R}_{\mathrm{p}}-\mathrm{R}_{\mathrm{b}}}{\sigma_{\mathrm{p}}}
$$

s.t.

$$
\begin{gathered}
R_{p}=\sum_{i=1}^{N} W_{i} \times R_{i} \\
\sum_{i=1}^{N} W_{i}=1
\end{gathered}
$$




$$
0,025 \leq W_{i} \leq 1, \quad i=1, \ldots, n
$$

\subsection{6 \\ Additional topics on portfolio formation}

\subsubsection{1 \\ Guidelines for portfolio formation}

As previously stated, four different classes portfolios (A, B, C and D) are formed for each firm group, which makes a total of 12 portfolios per year of the analysis. The compositions of portfolios A and B are already pre-defined inasmuch as the weights of each firm are proportional to their technical efficiency scores obtained in the DEA models, with the exception of the portfolios from the third group, where all firms participate with the same weights. In addition, as a general rule, should a firm have multiple assets available for trading on the BM\&FBOVESPA stock exchange, i.e., common and preferred stocks, its composition will be divided equally among them.

With regard to portfolio classes $\mathrm{C}$ and $\mathrm{D}$, the calculation of their optimal weights is not straightforward since it involves the solution of a linear programming (LP) problem. The LP, in turn, uses the values of each asset expected return and volatility as inputs. In this regard, we propose to estimate the expected return of each asset based on its daily historical data of one year. Basically, we simply average the historical returns of each asset, as follows:

$$
\mathrm{E}\left[R_{i}\right]=\bar{R}_{l}=\frac{\sum_{t=1}^{T} R_{i, t}}{T}
$$

where $T$ is the number of observation in the reporting year. By the same token, the volatility of each asset, i.e. $\sigma_{\mathrm{i}}$, is gauged using the standard error of the historical returns in the same time horizon as that of equation (42):

$$
\widehat{\sigma}_{1}=\sqrt{E\left(R_{i}-\bar{R}_{i}\right)^{2}}=\sqrt{\frac{1}{T-1} \sum_{t=1}^{T}\left(R_{i, t}-\bar{R}_{i}\right)^{2}}
$$


Finally, since the inputs of the LP problems in Portfolios C and D are calculated in an annual basis, the values of $\mathrm{E}\left[R_{i}\right]$ and $\widehat{\sigma}_{1}$ are subsequently multiplied by $T$ and $\sqrt{T}$, respectively.

\subsubsection{2}

\section{The Sharpe ratio benchmark for portfolio formation}

Aside from issues such as data frequency, number of assets and choice of constraints, the optimisation of the Maximum Sharpe ratio portfolio is also dependent on the benchmark in which the risk-adjusted excess return of the portfolio is measured. This benchmark can be the return on a corner bank savings account, a stock, a market index etc, and its proper selection basically relies on the strategy an investor is willing to employ. For particular purposes, in this work, the annual interbank deposit rate (CDI) was chosen to represent the Sharpe ratio benchmark when forming portfolios. The CDI was created in Brazil in the 1980s to insure a better distribution of the financial institutions' resources. Although its negotiation is restricted to the interbank market (banks and financial institutions), the CDI is the most widely used benchmark for the calculation (fixing) of reference interest rates.

\subsubsection{3}

\section{The beta of a portfolio}

Besides from the expected return and standard deviation, another important metric that needs to be considered when forming or evaluating portfolios is the beta, a measure of overall market risk. In general terms, the beta of an asset or portfolio is the measure of the risk arising from exposure to general market movements as opposed to idiosyncratic factors. Basically, the higher the beta, the more sharply the value of the investment can be expected to fluctuate in relation to a market index. The beta of a portfolio is calculated as follows:

$$
\beta_{p}=\boldsymbol{W} \boldsymbol{\beta}=\sum W_{i} \beta_{i}
$$

where $\beta_{i}$ is the individual beta of the $\mathrm{i}^{\text {th }}$ asset of the portfolio which, in turn, is defined as below: 


$$
\beta_{i}=\frac{\operatorname{cov}\left(R_{i}, R_{m}\right)}{\operatorname{var}\left(R_{m}\right)}=\frac{\sigma_{i, m}}{\sigma_{m}^{2}}
$$

where $m$ refers to the market portfolio, gauged here by its proxy, the IBOVESPA index. In this work, however, we follow Fama and Macbeth (1973) and use the market model to estimate the assets' betas, according to the following equation:

$$
\begin{gathered}
R_{i, t}=\alpha_{i}+\beta_{i} R_{m, t}+\epsilon_{i, t} \\
i=1, \ldots, N ; \quad t=1, \ldots, T
\end{gathered}
$$

where $\alpha_{i}$ is the asset's alpha, a measure of its return in excess of the market return ${ }^{6}$. Hence, if alpha is positive, it means the asset has performed better than expected. Similarly, a negative alpha means that the stock's performance has been worse than expected.

Under said framework, assets' betas are estimated by the values of the slope coefficients of their daily returns $\left(R_{i, t}\right)$ on the market portfolio returns $\left(R_{m, t}\right)$ in an ordinary least squares regression (OLS), while assets' alphas correspond to the values of the intercept coefficients.

\subsubsection{4 \\ Tests for stationarity}

To make sure that no spurious regressions occur while estimating individual betas through equation (46), all assets' returns time series are tested for stationarity. In this work, two different tests are used to cross-check the results: the augmented Dickey-Fuller (hereafter ADF) test, proposed by Said and Dickey (1984) as an extension of the Dickey-Fuller $\tau$ test (DICKEY AND FULLER, 1979) and the KPSS test, proposed by Kwiatkowski et al. (1992). The basic procedure of the former is to estimate an autoregressive model of order $p-\operatorname{AR}(p)$

\footnotetext{
${ }^{6}$ In broad terms, the alpha is defined as the abnormal rate of return on a security or portfolio in excess of what would be predicted by an equilibrium model like the market model or the Sharpe (1964) - Lintner (1965) - Mossin (1966) Capital Asset Pricing Model (CAPM). In other words, the estimated value of the alpha may vary slightly depending on the chosen methodology. The same goes for the beta.
} 
- and use the existence of a unit root as the null hypothesis $\left(\mathrm{H}_{0}\right)$. This model can be represented by the following equation:

$$
\Delta R_{i, t}=\beta_{1}+\beta_{2} t+\delta R_{i, t-1}+\sum_{j=1}^{p} \alpha_{j} \Delta R_{i, t-j}+u_{t}
$$

where $\Delta$ stands for the first difference operator, $\alpha_{j}$ is the $\operatorname{AR}(j)$ coefficient, $u_{t}$ is the error term and $\beta_{1}$ and $\beta_{2}$ represent the drift and the trend components of the model, respectively. In this work, however, these two last components are not included in the ADF test, since they are not expected to occur in a financial returns time series. The null hypothesis of this test states that $\delta=0$, i.e., there is a unit root $(\rho=1)$, and the $\tau$ test statistic is computed as:

$$
\tau=\frac{\hat{\delta}}{\operatorname{se}(\hat{\delta})}
$$

where $\hat{\delta}$ is the estimate of $\delta$ and $s e(\hat{\delta})$ is the coefficient standard error. The order of augmentation is often chosen by making use of information criteria, such as in Akaike (1974) or Schwarz (1978). Finally, the results for the critical values of the ADF $\tau$ statistic are derived from the asymptotic results of Mackinnon's (1996) simulations.

With regard to the KPSS test, the series is now assumed to be (trend-) stationary under the null and its Lagrange Multiplier (LM) test statistic is defined as:

$$
L M=\frac{\sum_{t} S(t)^{2}}{T^{2} f_{0}}
$$

where $f_{0}$ is an estimator of the residual spectrum at frequency zero and $S(t)=$ $\sum_{r=1}^{t} \widehat{u_{r}}$ stands for the cumulative residual function based on residuals from the ordinary least squares (OLS) regression of $R_{i, t}$ on the exogenous variables - its first $j$ lagged values $\left(R_{i, t-j}\right)$, in that case. For the KPSS tests used here, NeweyWest bandwidth was selected using Bartlett kernel spectral estimation method and the reported critical values for the LM test statistic are based upon the asymptotic results presented in Kwiatkowski et al. (1992). 


\section{3 Portfolio Evaluation}

In this last stage, comparisons among different group portfolios and between portfolios and the IBOVESPA, ISE and IEE indices are made on the basis of five different criteria: the Sharpe ratio (SHARPE, 1966), the Treynor's measure (TREYNOR, 1965), the Jensen's measure (JENSEN, 1968), the Sortino's ratio (SORTINO AND PRICE, 1994) and the Omega measure, proposed by Keating and Shadwick (2002a, b). These measures are briefly described below.

\subsection{1}

Sharpe Ratio (ShR)

As previously outlined, the Sharpe ratio (SHARPE, 1966), also known as Sharpe index, Sharpe measure, or reward-to-variability ratio, represents the differential return of a portfolio by unit of total risk. In other words, it measures the risk-adjusted excess return of an asset or a portfolio over its benchmark, generally a risk-free asset, as shown in Eq. (50):

$$
\operatorname{ShR}_{(p)}=\frac{R_{p}-R_{b}}{\sigma_{p}}
$$

where $R_{p}$ is the portfolio's return; $R_{b}$ is the return of the selected benchmark (generally gauged by a risk-free asset); and $\sigma_{p}$ is the standard deviation of the portfolio's returns.

\subsection{2}

\section{Treynor Ratio (TrR)}

The Treynor ratio (TREYNOR, 1965) represents the differential return of a portfolio by unit of its beta $\left(\beta_{p}\right)$, i.e., the risk arising from exposure to general market movements. 


$$
\operatorname{Tr} R_{(p)}=\frac{R_{p}-R_{b}}{\beta_{p}}
$$

\subsection{3}

\section{Jensen Ratio (JnR)}

The Jensen's measure (JENSEN, 1968), sometimes referred to as "Jensen's alpha", in its turn, represents the average return on a portfolio over and above that predicted by the Sharpe (1964) - Lintner (1965) - Mossin (1966) Capital Asset Pricing Model (CAPM), given the portfolio's beta and the average market return, according to the following equation:

$$
J n R_{(p)}=\alpha_{(p)}=R_{p}-\left[R_{f}+\beta_{p}\left(R_{m}-R_{f}\right)\right]
$$

where $R_{m}$ represents the market portfolio. In other words, the Jensen ratio is equivalent to the alpha of the portfolio obtained by the CAPM model.

In brief terms, the CAPM predicts that the only source of risk that is rewarded in an individual asset's expected risk premium is its variability in the market as a whole, with different asset's risk premiums depending on their correlation (as reflected in their beta-coefficients) with the rate of return on the market portfolio. Therefore, the expected return of a security or a portfolio equals the rate on a risk-free security plus a risk premium which depends on the asset's beta and the market premium $\left(R_{m}-R_{f}\right)$, as follows:

$$
R_{p}=R_{f}+\beta_{p}\left(R_{m}-R_{f}\right)
$$

In view of the above, it can be noted that the CAPM does not account for alternative sources of gains other than the market exposure. The results from the CAPM can be represented graphically by a straight line in the expected return Beta space, commonly referred to as the Security Market Line (SML), as illustrated in Figure 13, as follows. The excess of return over the SML is the Jensen's alpha and the slope of any line drawn in the $\mathrm{E}[\mathrm{R}] \mathrm{x} \beta$ space is the Treynor ratio. 
Figure 13 - The CAPM Security Market Line and the Jensen's alpha

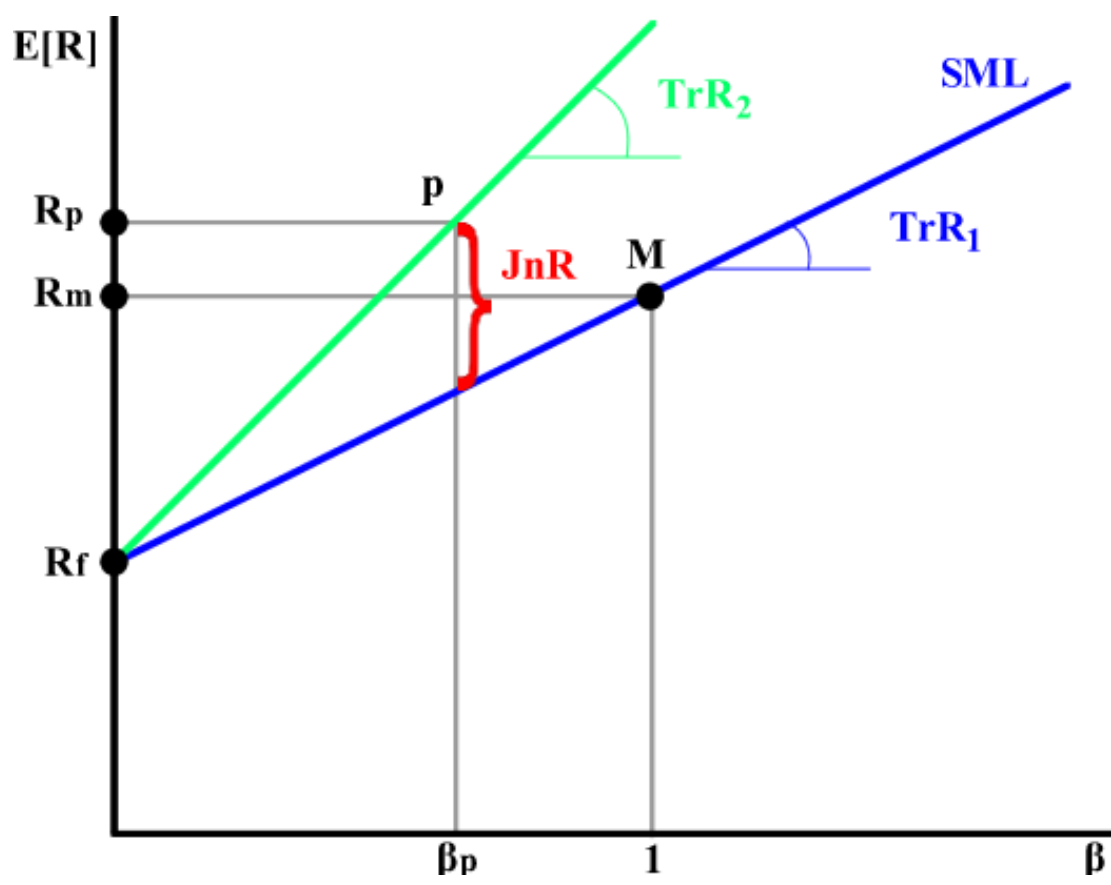

Source: Author's own.

\subsection{4 \\ Sortino Ratio (SoR)}

The Sortino's measure (SORTINO AND PRICE, 1994) is akin to the Sharpe and Treynor ratios, in the sense that it calculates the premium $\left(R_{p}-R_{b}\right)$ per unit of risk. Conversely, instead of using the portfolios's standard deviation $\left(\sigma_{p}\right)$ or its beta $\left(\beta_{p}\right)$, the Sortino's ratio is computed using the downside risk $\left(\sigma_{D R_{(p)}}\right)$, which considers only the portfolio's probability of incurring a return inferior to that acceptable by the investor $\left(R_{\min }\right)$. Thus, the Sortino's ratio is defined as:

$$
\operatorname{SoR}_{(p)}\left(R_{\text {min }}\right)=\frac{R_{p}-R_{b}}{\sigma_{D R_{(p)}}}
$$

whereas the portfolio's downside risk $\left(\sigma_{D R_{(p)}}\right)$ can be computed as follows: 


$$
\sigma_{D R_{(p)}}=\sqrt{\frac{\sum_{t=1}^{T} \operatorname{Min}\left[0 ;\left(R_{p, t}-R_{\min }\right)\right]^{2}}{T}}
$$

\subsection{5}

\section{Omega Ratio $(\Omega)$}

The previously outlined measures, albeit used extensively in various applications, are performed in the mean-variance framework and, therefore, require assumptions about the investor's utility function (namely a quadratic utility function) or about the normality of the assets' returns distribution. Nevertheless, it is common ground that a quadratic utility function is inconsistent with rational human behaviour. Moreover, the payoffs of portfolio insurance strategies are typically non-linear with respect to the risky reference asset, which induces asymmetric return distributions (BERTRAND AND PRIGENT, 2011). Scott and Horvath (1980) add that investors care about moments of higher order than the variance since they tend to like (positive) skewness and dislike kurtosis. More generally, they like odd moments and dislike even ones.

The inadequacy of traditional approaches has led to the introduction of new methods capable of dealing with return distributions which are not normally distributed. However, despite the improvement they can add to the analysis, these methods still reduce the dimensionality to a few characteristics and do not take into account moments of higher order than skewness and kurtosis (FAVREBULLE AND PACHE, 2003).

In light of the above, Keating and Shadwick (2002a, b) set forth a new performance measure, called the Omega measure, based on a gain-loss approach. It is calculated by dividing the probability of obtaining a return superior to a minimum expected return $\left(R_{\min }\right)$ by the probability of obtaining a return inferior to the same $R_{\min }$, as shown in the following equation:

$$
\Omega_{(p)}\left(R_{\min }\right)=\frac{\int_{R_{\min }}^{b}[1-F(x)] d x}{\int_{a}^{R_{\min }} F(x) d x}
$$


where $F(x)$ is the cumulative distribution function of the portfolio's returns defined by the interval $[\mathrm{a}, \mathrm{b}]$, as illustrated in Figure 14. In other words, the Omega measure is defined as the ratio of the expectation of gains (the return above the threshold) and the expectation of losses (the return below the threshold).

Figure 14 - The cumulative distribution of a portfolio's returns

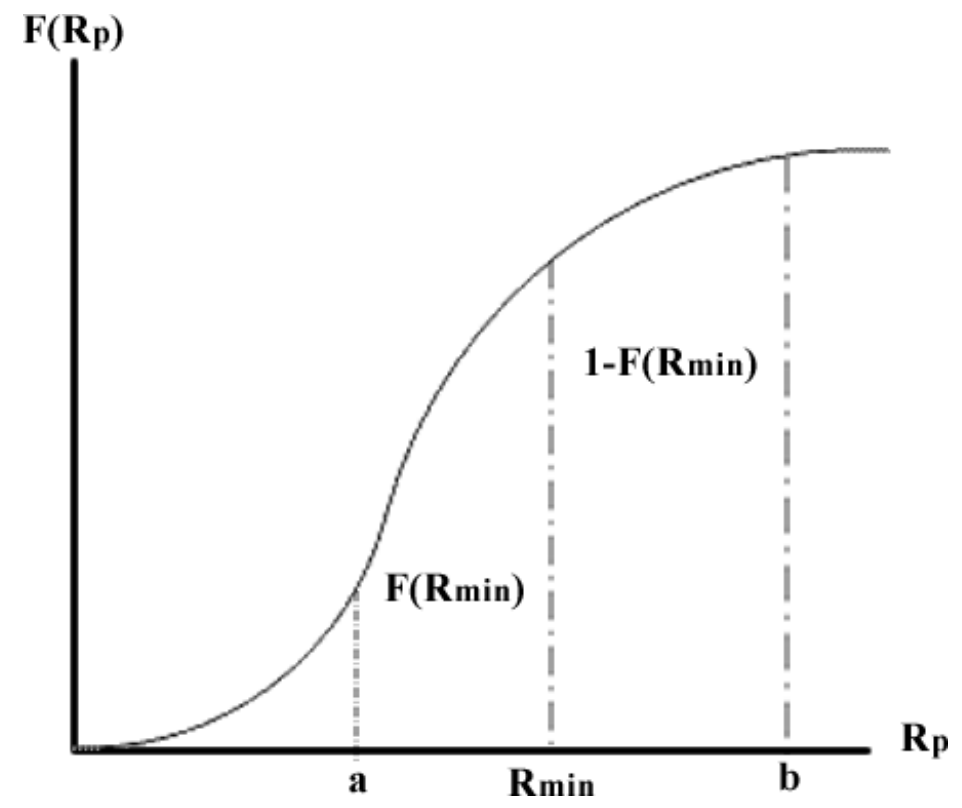

Source: Adapted from Keating and Shadwick (2002b).

The main advantage concerning the Omega measure is that it involves all the moments of the return distribution, including skewness and kurtosis. Furthermore, ranking is always possible, whatever the rational threshold $\left(R_{\min }\right)$ is, in contrast to the Sharpe ratio where this level is fixed and equal to the riskless return.

Finally, it is worth stressing that, according to Favre-Bulle and Pache (2003), the minimum sample size to entail consistent results with the Omega measure is 200 observations.

\subsection{6}

\section{Additional topics on portfolio evaluation}

\subsubsection{1}

\section{Test for normality}


As outlined in Cunha and Samanez (2013), assuming that the assets' returns are normally distributed may compromise the financial performance analysis based on traditional mean-variance measures. In this regard, even though it is common knowledge that the vast majority of financial time series is nonnormally distributed, a formal test is called for. To this end, we use the JarqueBera (JARQUE AND BERA, 1987 - henceforth JB) test, a goodness-of-fit measure of departure from normality, based on the sample kurtosis and skewness. Within the JB framework, the distribution is assumed to be normally distributed under the null hypothesis $\left(\mathrm{H}_{0}\right)$ and the test statistic, which follows a Chi-square distribution with two degrees of freedom, can be computed as below:

$$
J B=T\left[\frac{\left(S_{i}^{2}\right)}{6}+\frac{\left(K_{i}-3\right)^{2}}{24}\right]
$$

where $T$ denotes the number of observations and $S_{i}$ and $K_{i}$ respectively stand for the $i$-th asset skewness and kurtosis, which, in turn, are defined as follows:

$$
\begin{aligned}
& S_{i}= \sum_{t=1}^{T} \frac{\left(R_{i, t}-\bar{R}_{i}\right)^{3}}{T} \\
&\left.K_{i}\right)^{3} \sum_{t=1}^{T} \frac{\left(R_{i, t}-\bar{R}_{i}\right)^{4}}{T} \\
&\left(\sigma_{i}\right)^{4}
\end{aligned}
$$

For a normally distributed variable, $S=0$ and $K=3$. Hence, the JB test of normality is a test of the joint hypothesis that $\mathrm{S}$ and $\mathrm{K}$ are 0 and 3, respectively. In that case the value of the JB statistic is expected to be 0 .

\subsubsection{2}

\section{Performance evaluation tools: summary}

Table 1 below displays a summary of the financial performance measures selected in this work to evaluate each group portfolio, outlining their main advantages and disadvantages. 


\begin{tabular}{|c|c|c|c|c|}
\hline & Measure & Formula & Advantages & Disadvantages \\
\hline \multirow{3}{*}{ 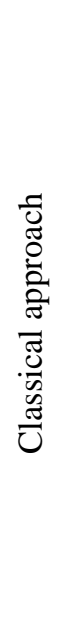 } & Sharpe ratio & $\frac{R_{p}-R_{b}}{\sigma_{p}}$ & $\begin{array}{l}\text { - Straightforward use; } \\
\text { - Standardises the relationship between risk and return } \\
\text { and thus can be used to compare different asset classes. }\end{array}$ & $\begin{array}{l}\text { - Standard deviation may not be an entirely appropriate } \\
\text { measure of risk; } \\
\text { - Loses its meaning when negative. }\end{array}$ \\
\hline & Treynor ratio & $\frac{R_{p}-R_{b}}{\beta_{p}}$ & - Straightforward use. & $\begin{array}{l}\text { - Only takes into account the systematic risk and, } \\
\text { therefore, a ranking of portfolios based on the Treynor } \\
\text { Ratio may be biased if portfolios are poorly diversified; } \\
\text { - Loses its meaning when negative. }\end{array}$ \\
\hline & Jensen ratio & $R_{p}-\left[R_{f}+\beta_{p}\left(R_{m}-R_{f}\right)\right]$ & $\begin{array}{l}\text { - Direct measure of the abnormal return that the } \\
\text { investors can gain or lose in a portfolio. }\end{array}$ & $\begin{array}{l}\text { - Only takes into account the systematic risk; } \\
\text { - Survivorship bias: one cannot sustain the argument that } \\
\text { portfolios can beat the market. }\end{array}$ \\
\hline \multirow{2}{*}{ 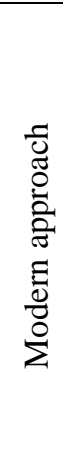 } & Sortino ratio & $\frac{R_{p}-R_{b}}{\sigma_{D R_{(p)}}}$ & $\begin{array}{l}\text { - Better than traditional measures when analising } \\
\text { highly volatile portfolios; } \\
\text { - Models more accurately asymmetric, non-normal } \\
\text { return distributions. }\end{array}$ & $\begin{array}{l}\text { - With downside risk there must be enough "bad" } \\
\text { observations so that the calculation is statistically } \\
\text { significant; } \\
\text { - Loses its meaning when negative. }\end{array}$ \\
\hline & Omega ratio & $\frac{\int_{R_{\min }}^{b}[1-F(x)] d x}{\int_{a}^{R_{\min }} F(x) d x}$ & $\begin{array}{l}\text { - Captures all of the higher moment information in the } \\
\text { returns distribution and also incorporates sensitivity to } \\
\text { return levels; } \\
\text { - Ranking is always possible, whatever the }\left(R_{\text {min }}\right) \text { is. }\end{array}$ & $\begin{array}{l}\text { - Occasional difficulties may arise when estimating the } \\
\text { probability distribution of the portfolios' returns. }\end{array}$ \\
\hline
\end{tabular}

Source: Author's own. 


\section{4 \\ Results and discussion}

\section{1 \\ Sample}

Originally, all Brazilian publicly traded electric companies were included in the analysis, i.e., those listed on the Brazilian stock exchange. No distinction was made regarding companies' specific functions, such as generation, transmission or distribution. An extensive list of those companies can be found at the BM\&FBOVESPA portal (http://www.bmfbovespa.com.br/). The initial sample comprised 67 firms. However, since some of these companies were only traded on the over-the-counter (OTC) markets during the years of portfolio formation (2009-2012), the sample size was reduced to a total of 36 firms, with the first 21 releasing annual reports on a regular basis, as depicted in Table 2 .

In addition to the information gathered from the selected firms' annual social reports, daily closing quotations of firms' stock prices for the years of 2009 to 2013 (evaluation period) were also collected from the BM\&FBOVESPA website. In total, 51 stocks, comprising common and different classes of preferred stocks, as well as units, were used in portfolio formation. An extensive list of all publicly traded assets available for portfolio formation can be found in Appendix A. Appendix B, in turn, encompasses all assets from electric firms that were not included in the analysis and the reasons for not doing so.

Further, it is important to underscore that the original prices were adjusted for splits, reverse splits, dividends, mergers and other corporate events in accordance to the standards of the Center for Research in Security Prices (CRSP) (2014). In general terms, an adjustment base date is chosen as the anchor date. All data on this date are unadjusted, and other data are converted based on the split events between the base date and the time of that data. The adjustment base date is usually chosen to be the last available day of trading. In order to save space, formulas and methodologies used to derive the adjusted prices are not explained here. The interested reader is referred to CSRP (2014). 
Table 2 - Initial sample

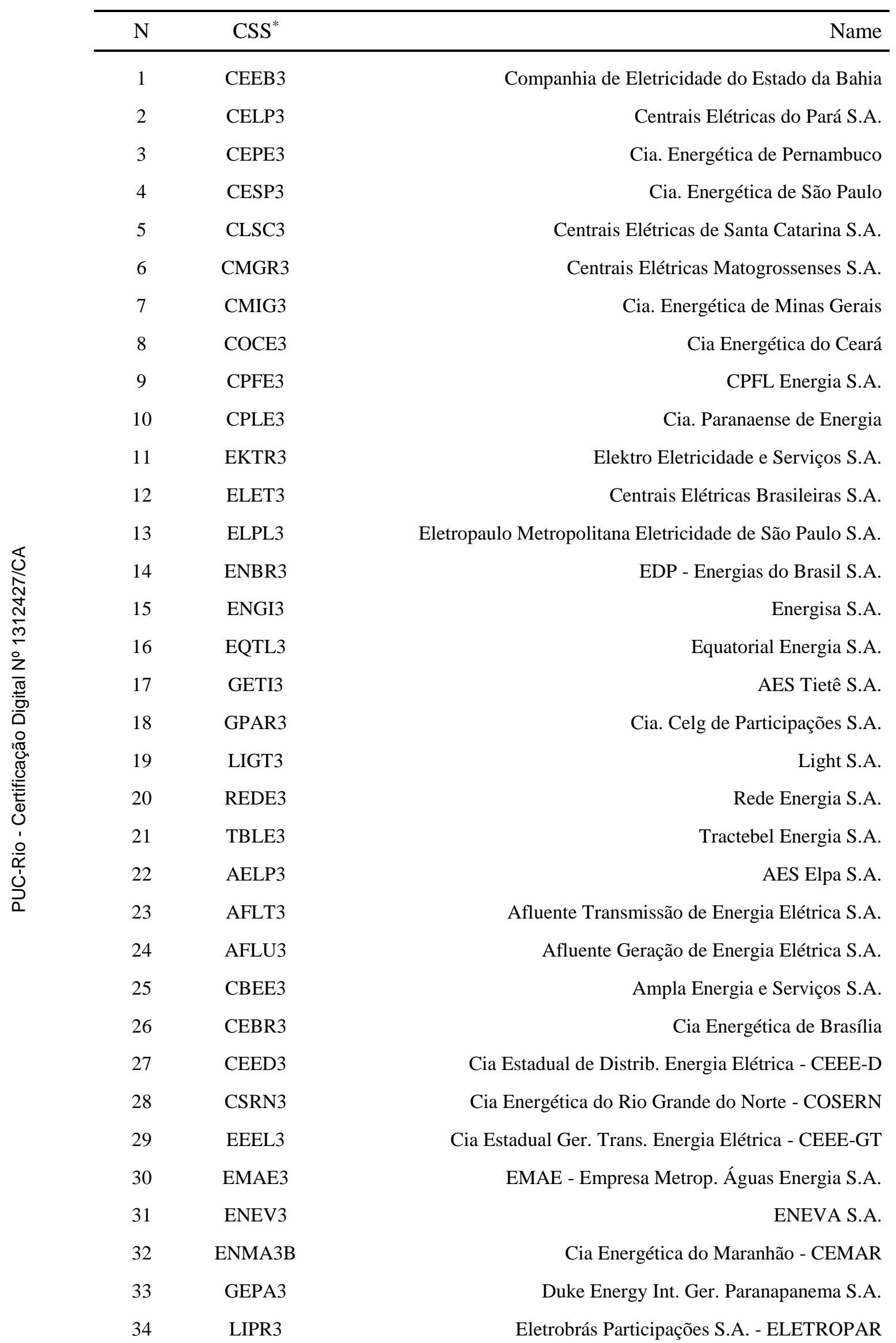


*CSS denotes the common stock symbol of the company.

Source: Adapted from BM\&FBOVESPA (2014).

Since the analysis was carried out both ex-post, i.e., at the same years that portfolios were formed, and ex-ante, where portfolios' performances were assessed in the subsequent year following their formation, the evaluation period comprised the years of 2009-2012 for the ex-post evaluation and the years of 2009-2013 for the ex-ante evaluation.

\section{2 \\ ESG performance}

As previously outlined in section 3.1.3, for each year of the portfolio formation period, specific data about the companies were collected to calculate the desired ESG performance indicators, which will serve as the basis of comparison in the DEA models, i.e., the input and output variables. They are as follows:

- Inputs: Ratio between net annual revenue and total expenditure in environmental activities (NAR/Totex) - Input 01.

- Outputs: Environmental Disclosure Score (EDS) - output 01; Social Disclosure Score (SDS) - output 02; and Corporate Governance Disclosure Score (CGDS) - output 03.

The ESG composite disclosure scores, calculated by Bloomberg ESG, are principally based on GRI standards and reflect companies' efforts to become more socially responsible and to disseminate their outcomes to the general public. The scoring methodology is completely transparent on the system, and the disclosure 
of all data fields would give a company a perfect score of $100^{7}$. It is also worth noting that data points are weighted differently by sector and decimal numbers may be used. Even so, since ESG disclosure scores are more concerned with capturing the breadth of reporting rather than the quality of reported information, we also include the total expenditure in environmental activities (Totex) as an important factor to measure companies' efforts to become more socially responsible. Since inputs in DEA models follow "the less the better rule" when assessing companies' performances, Totex is used as the denominator of the NAR/Totex ratio, the only input in this work. In other words, should concerns towards the environment be embedded in a company's culture, its NAR/Totex ratio will probably be lower than the average for its competitors.

Following the reasons stated in section 3.1.3, an output-oriented BCC/VRS model was used to measure the technical efficiency of DMUs in each year of the analysis. Although the initial sample comprised 21 firms that released annual social reports on a regular basis, some of them did not disclose all the required information to obtain the input and output variables in all years of the portfolio formation period. Therefore, the final DEA models encompassed 20 DMUs for the year of 2009, 21 for 2010, 18 for 2011 and 12 for 2012. The necessary data required to obtain the DEA indicators can be found in Appendix C. All calculations were made using the 3.0 version of the ISYDS (Integrated System for Decision Support) software package (MEZA et al., 2005). The entire sample as well as the DEA efficiency results for the years of 2009 to 2012 are presented in Table 3, as follows.

Table 3 - DEA efficiency results

\begin{tabular}{llllr}
\hline CSS & 2009 & 2010 & 2011 & 2012 \\
\hline CEEB3 & 1.000 & 1.000 & 1.000 & 1.000 \\
CELP3 & 0.745 & 0.681 & 0.715 & - \\
CEPE3 & 1.000 & 1.000 & 1.000 & 1.000
\end{tabular}

\footnotetext{
${ }^{7}$ It should be stressed, though, that ESG disclosure scores should not be seen solely as measures of the amount of information disclosed by firms. They also capture firms' efforts to become more socially responsible insofar as such organisations must meet multiple environmental, social and governance demands to disclose some items from their annual social reports. Furthermore, it is assumed that even the fields that do not require any pre-requisites for being filled out will only be fulfilled if a firm presents positive results concerning their particular matters.
} 


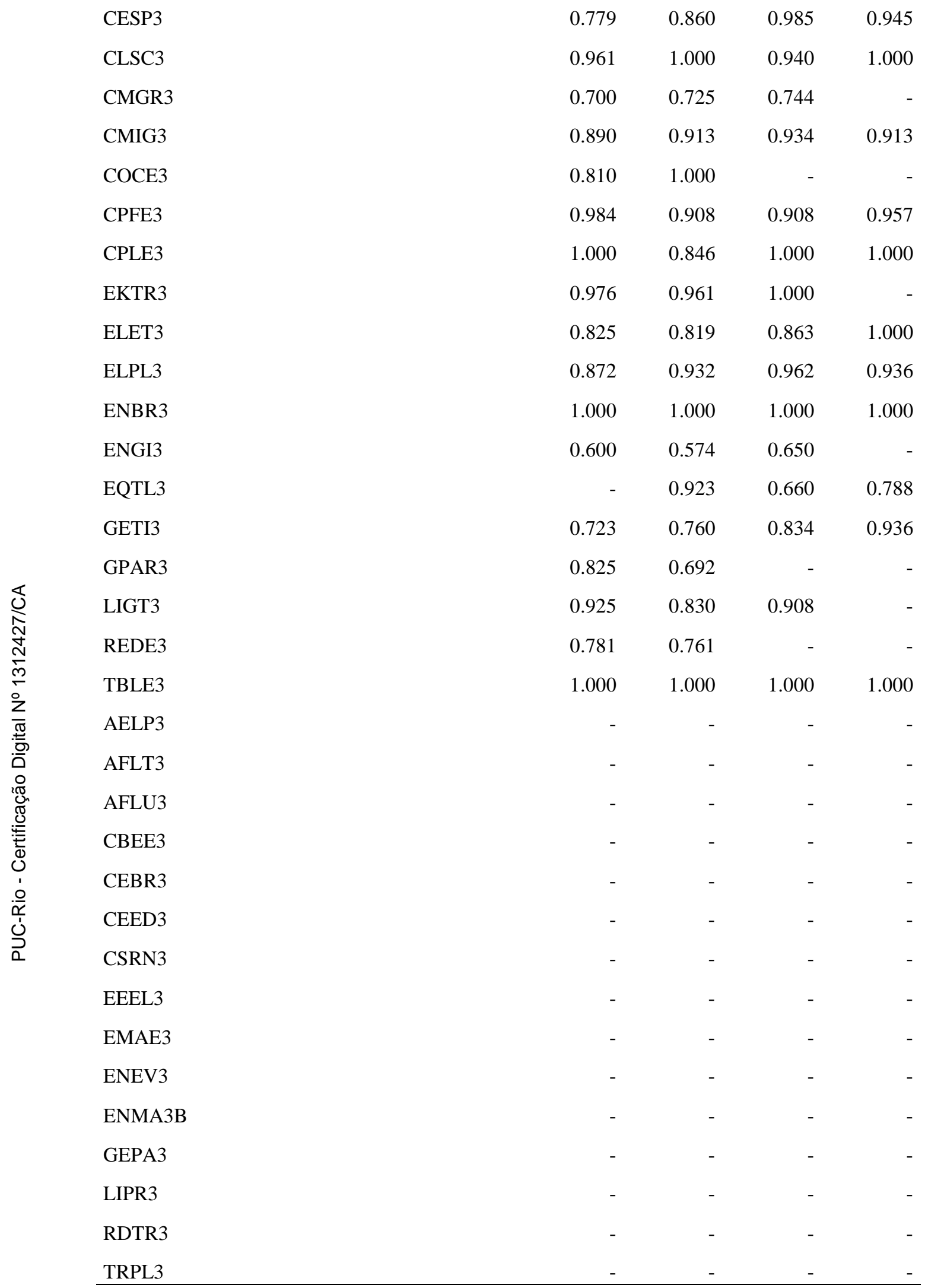

*CSS denotes the common stock symbol of the company.

Source: Author's own. 


\section{3 \\ Data handling and portfolio formation}

In this work, the daily return of a portfolio is computed according to equation (24), i.e., as a weighted average of the individual assets' returns within the portfolio. Hence, after having obtained all necessary data, the price returns time series were generated from the adjusted ${ }^{8}$ price time series by making use of a differentiation mechanism, whose general formula is:

$$
R_{t}=\ln \left(\frac{P_{t}}{P_{t-1}}\right)
$$

where $P_{t}$ and $P_{t-1}$ represent the adjusted prices at times $t$ and $t-1$, respectively.

Further, it is important to underscore that assets' betas are estimated by the values of the slope coefficients of their daily returns $\left(R_{i, t}\right)$ on the market portfolio returns $\left(R_{m, t}\right)$, according to equation (46). Therefore, and since assets' daily returns are also used when computing the variance-covariance matrix of portfolios, it is important to make sure that the price returns time series are stationary, to rule out spurious relationships. For this purpose, the ADF and KPSS unit root tests, described in details in section 3.2.6.4, were applied to the generated returns. The results from both tests are listed in Appendix D and suggest that all assets returns are indeed stationary.

Finally, all price returns time series were also tested for normality using the JB methodology described in section 3.3.6.1. As expected, the results, also illustrated in Appendix D, clearly indicate that the normality assumption does not hold for any of the generated returns.

After the data handling, a total of 12 portfolios were formed per year of the analysis - four for each ESG performance group. As already mentioned, the first group comprises only firms with the best ESG practices, i.e., with the highest DEA efficiencies; the second includes assets from firms that also released annual social reports, but with the lowest DEA efficiency values; and the last group encompasses all firms that did not produce any social reports during the years of

\footnotetext{
${ }^{8}$ As previously outlined in section 4.1 , the adjusted prices were obtained from the original prices time series using the methodology depicted in the Center for Research in Security Prices (CRSP) (2014).
} 
the analysis. Portfolios classes are explained in details in section 3.2.2. Appendix E, in turn, lists all formed portfolios during the years of portfolio formation (20092012).

\section{4 Ex-post evaluation}

\subsection{1 Preliminary data on risk-return composition}

Table 4, as follows, outlines the results obtained in the ex-post evaluation of formed portfolios, using the following set of elementary measures: annual expected return, annual volatility, coefficient of variation, beta and alpha. The annual expected return is computed in the following way: (a) first, the arithmetic means of each portfolio returns are obtained for the entire period of ex-post evaluation (2009-2012), which comprises a total of 988 observations (b) then, the means are multiplied by 252, the approximate number of trading days in a year. With regard to the annual volatilities, the value for each portfolio is gauged by the annual standard error $($ s.e. $=\hat{\sigma})$ which, in turn, is obtained by multiplying the standard deviation of their returns by the square root of $252(\sqrt{252})$.

The coefficient of variation (CV), in its turn, is a standardised measure that shows the extent of variability in relation to the mean of the population. It is defined as the ratio of the standard deviation $\sigma$ to mean of a population $(\mu)$. Nevertheless, since we are dealing with samples, in this work, the CV is estimated as follows:

$$
C V=\hat{\sigma} / E[R]
$$

where $\hat{\sigma}$ is the annual standard error and $E[R]$ is the annual expected return.

Finally, the values of the betas and alphas are calculated using the methodology depicted in section 3.2.6.3.

As a preliminary assessment, the results from Table 4 indicate that the best relative performances, i.e., disregarding the indices, in terms of risk-return 
trade-off were achieved in the first group portfolios, followed by those from the second group. Portfolios from the third group, in spite of seeming less susceptible to market fluctuations (as it can be stated by their lower values of beta in comparison to the first and second group portfolios), present substantially higher values of overall risk, gauged by the annual standard error. In addition, with the exception of the D class portfolios, portfolios from the third group present the lowest expected returns. As for the last measure, we leave the comments for next Table, which also brings the Jensen's alpha for every index and every group portfolio using different benchmarks.

As for the financial outcomes of the selected indices, it was already expected that their performances would be substantially higher than the majority of formed portfolios. There are several reasons that support this view: first, the composition of assets within such indices may vary along the year, allowing minor adjustments to be made until the end results meet the standards required; second, the indices have a wider range of assets available when forming their theoretical portfolios; and finally, their assets usually offer greater market liquidity than those from the Brazilian electric sector. Even so, socially responsible portfolios formed on the basis of maximum Sharpe ratios (D class portfolios) presented more attractive options in terms of risk-return trade-off than any other market index, as depicted in the lower part of Table 4.

Table 4 - Ex-post evaluation: Preliminary data on risk-return composition

\begin{tabular}{cccccc}
\hline \hline & $\begin{array}{c}\mathrm{E}[\mathrm{R}] \\
\text { (p. a.) }\end{array}$ & $\begin{array}{c}\widehat{\sigma} \\
\text { (p. a.) }\end{array}$ & $\mathrm{CV}$ & $\beta$ & $\alpha$ \\
\hline \hline IBOV & $12.36 \%$ & $24.93 \%$ & 2.02 & 1.00 & 0.00 \\
IEE & $16.14 \%$ & $15.11 \%$ & 0.94 & 0.38 & 0.05 \\
ISE & $19.60 \%$ & $21.40 \%$ & 1.09 & 0.80 & 0.08 \\
\hline \hline
\end{tabular}

Portfolios A

\begin{tabular}{rccccc}
\hline \hline $1^{\text {st }}$ group & $10.97 \%$ & $16.58 \%$ & 1.51 & 0.19 & 0.01 \\
$2^{\text {nd }}$ group & $9.22 \%$ & $16.76 \%$ & 1.82 & 0.27 & -0.01 \\
$3^{\text {rd }}$ group & $1.13 \%$ & $56.44 \%$ & 50.07 & 0.04 & -0.09 \\
\hline \hline
\end{tabular}




\begin{tabular}{cccccc}
\hline \hline $1^{\text {st }}$ group & $9.92 \%$ & $16.62 \%$ & 1.67 & 0.19 & 0.00 \\
$2^{\text {nd }}$ group & $9.58 \%$ & $17.35 \%$ & 1.81 & 0.26 & -0.01 \\
$3^{\text {rd }}$ group & $1.13 \%$ & $56.44 \%$ & 50.07 & 0.04 & -0.09 \\
\hline \hline \multicolumn{5}{c}{ Portfolios C } \\
\hline \hline $1^{\text {st }}$ group & $11.80 \%$ & $10.91 \%$ & 0.92 & 0.14 & 0.02 \\
$2^{\text {nd }}$ group & $10.42 \%$ & $12.84 \%$ & 1.23 & 0.20 & 0.00 \\
$3^{\text {rd }}$ group & $5.75 \%$ & $17.08 \%$ & 2.97 & 0.08 & -0.04 \\
\hline \hline & & & & \\
& & & & \\
\hline \hline & & & & \\
$1^{\text {st }}$ group & $24.96 \%$ & $15.08 \%$ & 0.60 & 0.18 & 0.15 \\
$2^{\text {nd }}$ group & $24.12 \%$ & $17.98 \%$ & 0.75 & 0.24 & 0.14 \\
$3^{\text {rd }}$ group & $25.08 \%$ & $39.61 \%$ & 1.58 & 0.04 & 0.15 \\
\hline \hline
\end{tabular}

Notes: p. a. stands for per annum.

Source: Author's own.

It is worth highlighting that the values illustrated in Table 4 holds for the whole period of the ex-post evaluation. Even so, we also computed the annual expected returns and volatilities for each year of portfolio formation. The interested reader is referred to the graphs in Appendix F. These charts illustrate the efficient frontier and the ex-post plots (E[R] x $\sigma$ space) of Portfolios A, B, C and D for the years of 2009 to 2012.

\subsection{2}

Financial performance indicators

The performance results of each group portfolio in terms of Sharpe, Treynor and Jensen's measures are illustrated in Table 5. For robustness checks, three different cases were proposed for the Sharpe and Treynor ratios: first, calculations were made using the market portfolio itself as benchmark. Then, the risk-free rate was represented by either the annual savings rate (ASR) or the interbank deposit rate (CDI). Irrespective of the scenario, the best results were achieved in the first group portfolios, followed by those from the second group. With regard to the Jensen ratio, the same pattern could be observed for portfolios 
Table 5 - Ex-post - Sharpe, Treynor and Jensen measures (whole period)

\begin{tabular}{|c|c|c|c|c|c|c|c|c|}
\hline & \multicolumn{3}{|c|}{ ShR } & \multicolumn{3}{|c|}{$\operatorname{TrR}$} & \multicolumn{2}{|c|}{$\mathrm{JnR}$} \\
\hline & IBOV-based & ASR-based & CDI-based & IBOV-based & ASR-based & CDI-based & ASR-based & CDI-based \\
\hline IBOV & 0.000 & 0.215 & 0.098 & 0.000 & 0.054 & 0.025 & 0.000 & 0.000 \\
\hline IEE & 0.251 & 0.605 & 0.413 & 0.099 & 0.239 & 0.163 & 0.071 & 0.053 \\
\hline ISE & 0.338 & 0.589 & 0.453 & 0.091 & 0.158 & 0.122 & 0.083 & 0.077 \\
\hline \multicolumn{9}{|c|}{ Portfolios A } \\
\hline $1^{\text {st }}$ group & -0.084 & 0.240 & 0.064 & -0.072 & 0.206 & 0.055 & 0.029 & 0.006 \\
\hline $2^{\text {nd }}$ group & -0.187 & 0.133 & -0.041 & -0.118 & 0.084 & -0.026 & 0.008 & -0.013 \\
\hline $3^{\text {rd }}$ group & -0.199 & -0.104 & -0.155 & -2.708 & -1.415 & -2.117 & -0.061 & -0.089 \\
\hline \multicolumn{9}{|c|}{ Portfolios B } \\
\hline $1^{\text {st }}$ group & -0.146 & 0.176 & 0.001 & -0.128 & 0.154 & 0.001 & 0.019 & -0.004 \\
\hline $2^{\text {nd }}$ group & -0.160 & 0.149 & -0.019 & -0.107 & 0.100 & -0.013 & 0.012 & -0.010 \\
\hline $3^{\text {rd }}$ group & -0.199 & -0.104 & -0.155 & -2.708 & -1.415 & -2.117 & -0.061 & -0.089 \\
\hline \multicolumn{9}{|c|}{ Portfolios C } \\
\hline $1^{\text {st }}$ group & -0.051 & 0.441 & 0.174 & -0.040 & 0.352 & 0.139 & 0.041 & 0.016 \\
\hline $2^{\text {nd }}$ group & -0.151 & 0.267 & 0.040 & -0.098 & 0.172 & 0.026 & 0.024 & 0.000 \\
\hline $3^{\text {rd }}$ group & -0.387 & -0.073 & -0.243 & -0.794 & -0.149 & -0.499 & -0.017 & -0.044 \\
\hline \multicolumn{9}{|c|}{ Portfolios D } \\
\hline $1^{\text {st }}$ group & 0.836 & 1.191 & 0.998 & 0.709 & 1.010 & 0.847 & 0.170 & 0.146 \\
\hline $2^{\text {nd }}$ group & 0.655 & 0.953 & 0.791 & 0.486 & 0.708 & 0.588 & 0.158 & 0.136 \\
\hline $3^{\text {rd }}$ group & 0.321 & 0.457 & 0.383 & 2.980 & 4.235 & 3.554 & 0.179 & 0.151 \\
\hline
\end{tabular}

Source: Author's own. 
A to $\mathrm{C}$, with the first group offering higher excess returns, followed by the second group. The only exception occurs in the maximum Sharpe portfolios (Portfolios D), where the best Jensen results were achieved in the third group.

Table 6, in turn, lists the performances for each group portfolio in terms of Sortino (SoR) and Omega $(\Omega)$ ratios. SoR values are CDI-based, i.e., they use the average annual interbank deposit rate as benchmark.

Table 6 - Ex-post - Sortino and Omega ratios (whole period)

\begin{tabular}{ccccccc}
\hline \hline & \multicolumn{3}{c}{ SoR $\left(\mathrm{R}_{\min }\right)$} & \multicolumn{3}{c}{$\Omega\left(\mathrm{R}_{\min }\right)$} \\
& $\mathrm{R}_{\min }(-2,0 \%)$ & $\mathrm{R}_{\min }(0 \%)$ & $\mathrm{R}_{\min }(+2,0 \%)$ & $\mathrm{R}_{\min }(-2,0 \%)$ & $\mathrm{R}_{\min }(0 \%)$ & $\mathrm{R}_{\min }(+2,0 \%)$ \\
\hline \hline IBOV & 5.974 & 2.264 & 0.994 & 10.904 & 1.020 & 0.089 \\
IEE & 24.101 & 9.094 & 2.893 & 64.867 & 1.129 & 0.011 \\
ISE & 24.505 & 9.128 & 3.626 & 16.643 & 1.084 & 0.060 \\
\hline \hline
\end{tabular}

Portfolios A

\begin{tabular}{ccccccc}
\hline \hline $1^{\text {st }}$ group & 2.554 & 1.362 & 0.482 & 40.167 & 0.941 & 0.023 \\
$2^{\text {nd }}$ group & -1.723 & -0.872 & -0.307 & 43.909 & 1.004 & 0.016 \\
$3^{\text {rd }}$ group & -3.823 & -3.434 & -2.561 & 16.333 & 0.937 & 0.050 \\
\hline \hline
\end{tabular}

Portfolios B

\begin{tabular}{ccccccc}
\hline \hline $1^{\text {st }}$ group & 0.045 & 0.024 & 0.008 & 40.167 & 0.949 & 0.023 \\
$2^{\text {nd }}$ group & -0.776 & -0.406 & -0.146 & 46.048 & 0.972 & 0.021 \\
$3^{\text {rd }}$ group & -3.823 & -3.434 & -2.561 & 16.333 & 0.937 & 0.050 \\
\hline \hline
\end{tabular}

Portfolios C

\begin{tabular}{ccccccc}
\hline \hline $1^{\text {st }}$ group & 23.133 & 4.055 & 0.918 & 122.500 & 0.956 & 0.007 \\
$2^{\text {nd }}$ group & 2.903 & 0.878 & 0.242 & 64.867 & 1.050 & 0.009 \\
$3^{\text {rd }}$ group & -8.215 & -5.507 & -1.891 & 69.571 & 0.896 & 0.013 \\
\hline \hline
\end{tabular}

Portfolios D

\begin{tabular}{rcccccc}
\hline \hline $1^{\text {st }}$ group & 80.912 & 23.801 & 7.096 & 57.118 & 1.129 & 0.027 \\
$2^{\text {nd }}$ group & 58.334 & 18.839 & 6.469 & 25.000 & 1.098 & 0.036 \\
$3^{\text {rd }}$ group & 11.300 & 9.269 & 5.582 & 25.000 & 0.882 & 0.046 \\
\hline \hline
\end{tabular}

Notes: Sortino ratios are CDI-based.

Source: Author's own. 
Concerning the first measure, the results clearly indicate higher premiums per unit of downside risk for the first group portfolios, suggesting that socially responsible portfolios present lower probabilities of large losses. In addition, albeit it is difficult to compare investments when the Sortino ratio is negative, it can be easily perceived that portfolios from the second group outpace those from the third in this aspect. This is quite clear when one compares SoR values in portfolios classes $\mathrm{C}$ and $\mathrm{D}$. As for the Omega ratio, the best results for thresholds lower than $0 \%$ were achieved in the second group portfolios for cases $\mathrm{A}$ and $\mathrm{B}$ and in the first group portfolios for cases $\mathrm{C}$ and D. Conversely, third group portfolios present a small advantage if one considers the probability of obtaining a return superior to $2 \%$, which is quite uncommon in practice. Additional information concerning indices and portfolios return probability distribution and the sensitivity of their Omega measure results in relation to the minimum expected threshold $\left(\mathrm{R}_{\min }\right)$ can be found in Appendix $\mathrm{G}$.

Finally, for a straightforward view, Figure 15 below summarises the overall ex-post results in terms of all five financial metrics (radar charts). Values for ShR, TrR, JnR and SoR are CDI-based.

Figure 15 - Indices and firm groups ex-post performances (whole period)

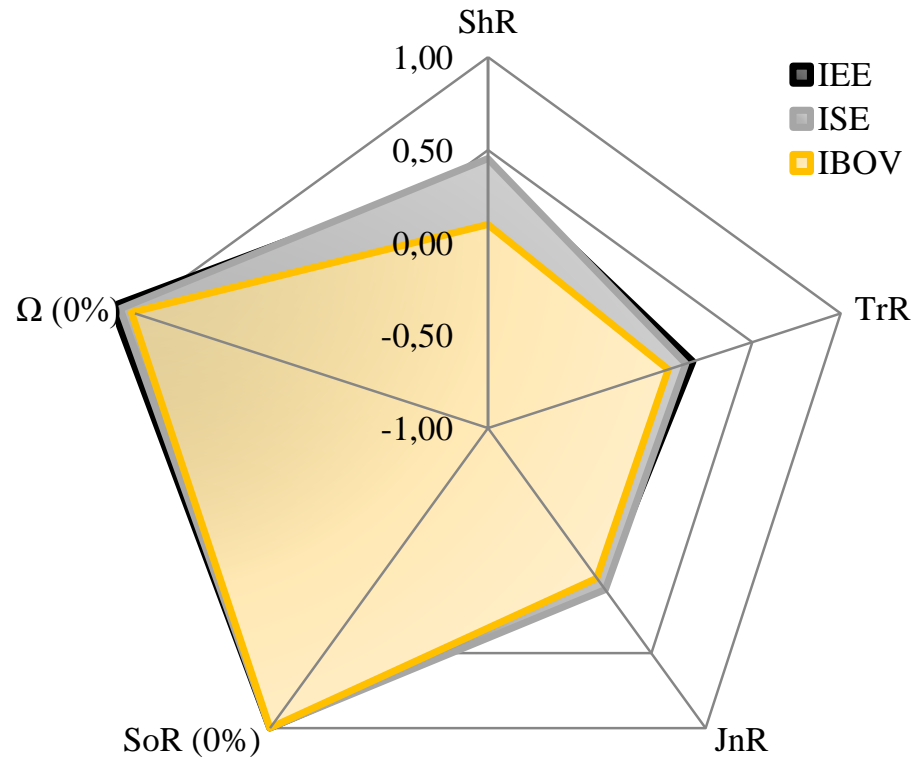

Indices 


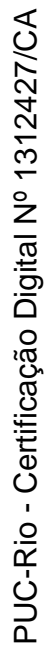

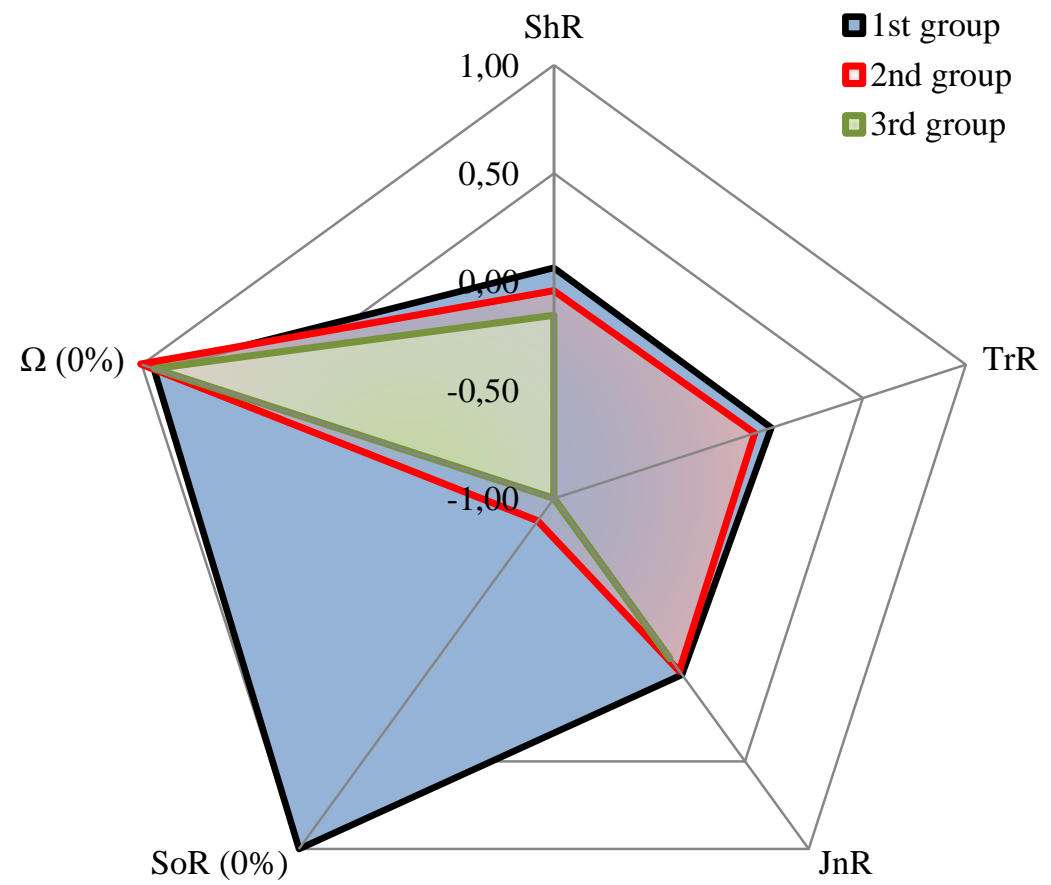

Portfolios A

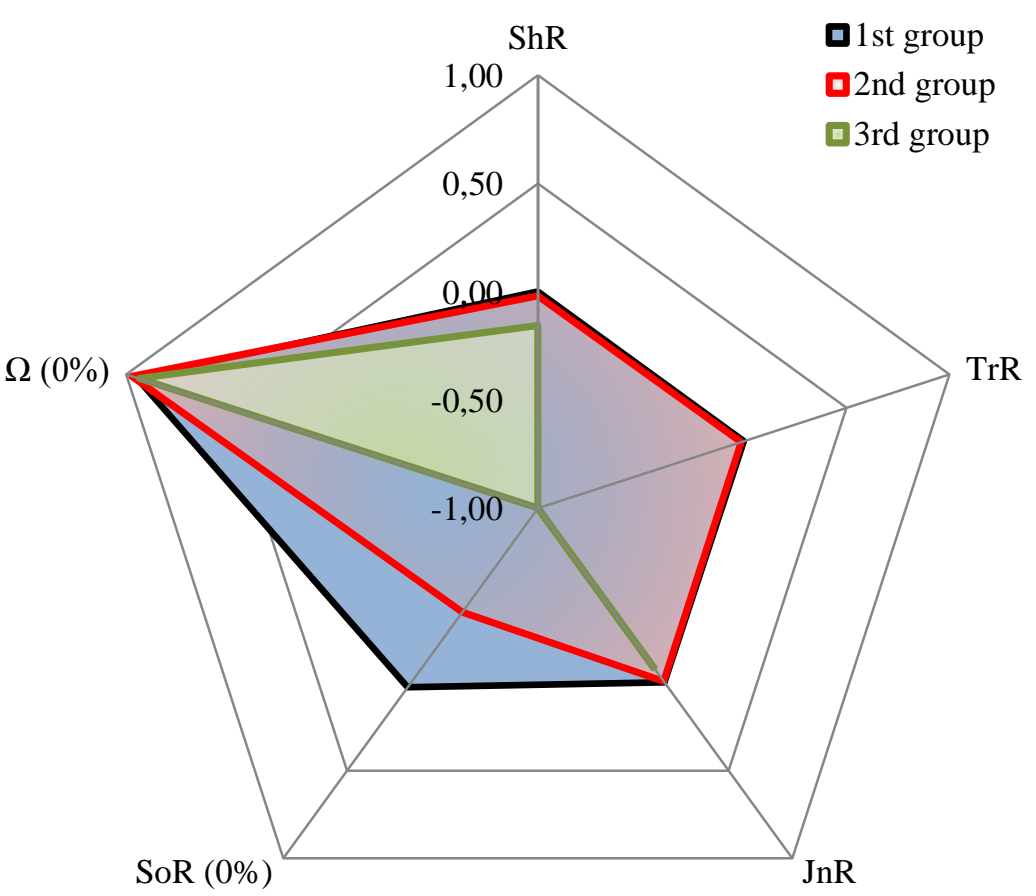

Portfolios B 


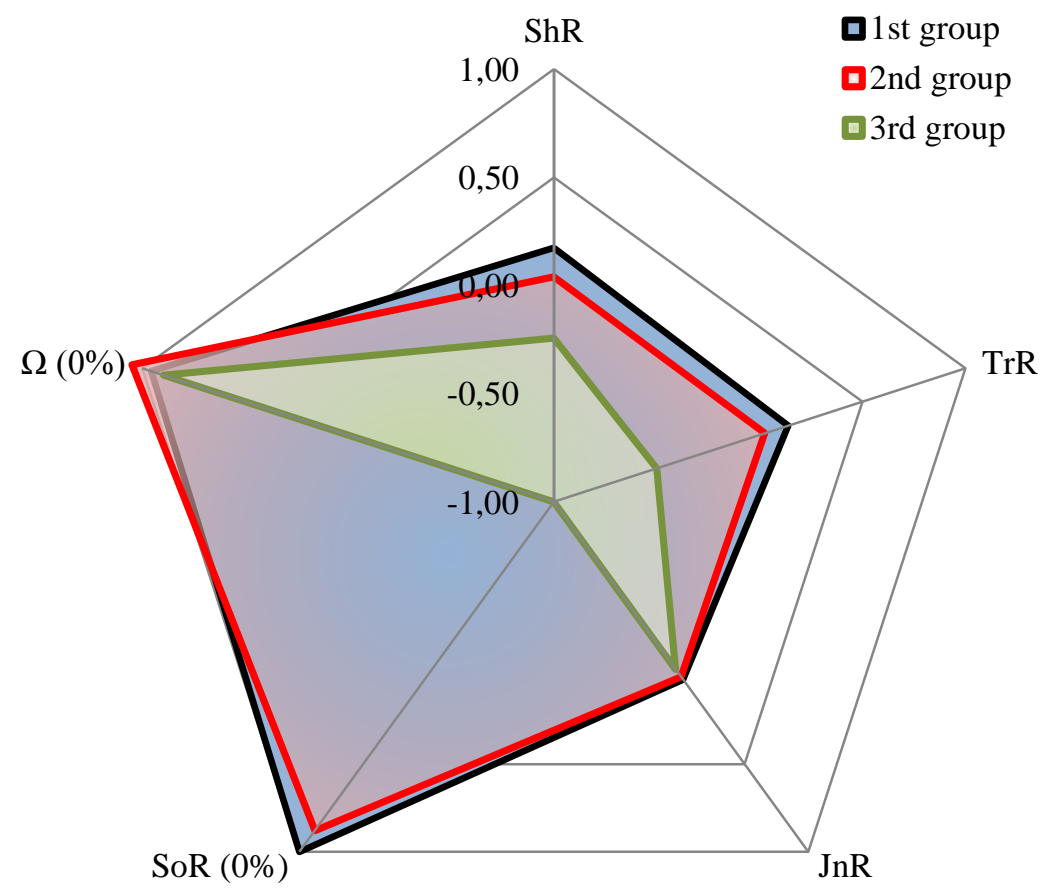

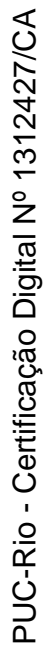

Portfolios C

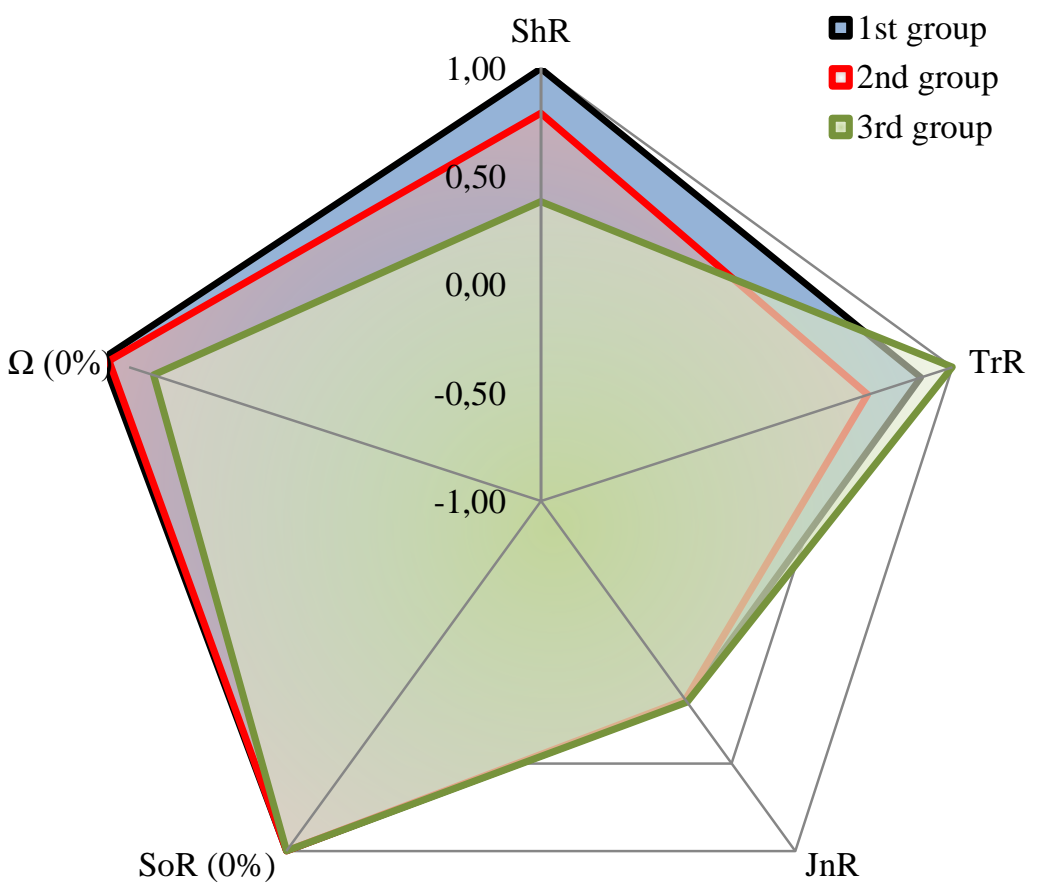

Portfolios D

Source: Author's own. 
In general, it can be stated that the best ex-post results were achieved in the first group portfolios, followed by those from the second group. In other words, socially responsible portfolios in the Brazilian electric sector not only offered higher excess returns per unit of risk but also presented lower probabilities of large losses during the analysis period.

\subsection{3}

\section{Financial behaviour over the years}

To summarise, the behaviour of each group portfolios in scenarios A to D are illustrated in Figures 17 to 20, respectively. Figure 16, in its turn, shows the IBOVESPA, IEE and ISE indices historical data for the same period. The base period is set at $2009=1000$. According to these graphs, all socially responsible portfolios - first and second groups - yielded positive returns during the greater part of the analysis period. Their performances were considerably high until the first half of 2012. Nevertheless, their records plummeted in the remainder of the year. Yet this may be attributed to the drops in prices in the Brazilian electric sector as a whole, as illustrated by the sharp decline in the IEE index in Figure 16. Third group portfolios, in contrast, followed the same upward trend as the first and second group portfolios until the beginning of the second year of the analysis but their performances were considerably lower during the rest of the period.

Another point is worth emphasising as well: whilst the IBOVESPA and ISE demonstrated similar results for the majority of the observations, the IEE has shared a negative relationship with these indices since the first half of 2010, suggesting that the Brazilian electric sector has behaved quite differently from the market as a whole in recent years. In other words, even though there is consistent empirical evidence in favour of socially responsible firms in terms of financial performance for the Brazilian electric sector, one cannot readily extrapolate the findings from this study to other sectors of the economy.

Figure 16 - IBOVESPA, IEE and ISE historical data (2009-2012). Base fitted for 1000 points on $31 / 12 / 2008$. 


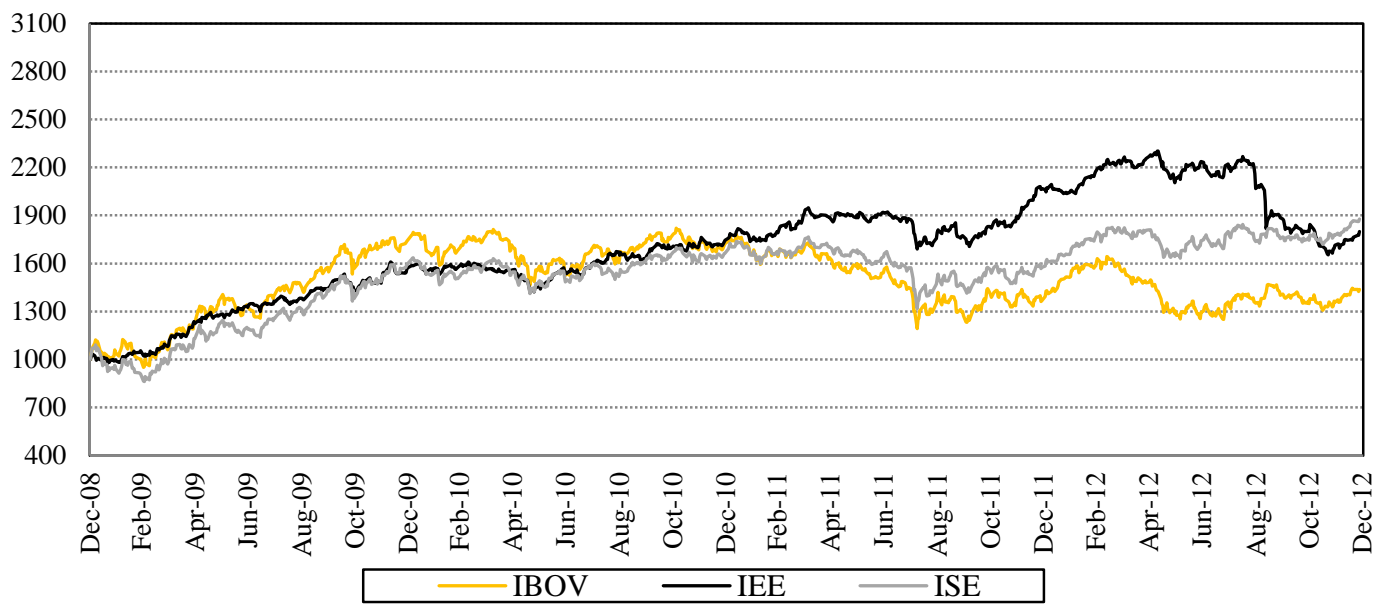

Source: BM\&FBOVESPA (2014).

Figure 17 - Portfolios A (2009-2012). Base fitted for 1000 points on 31/12/2008.

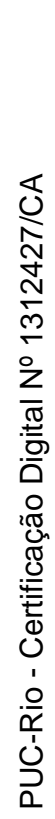

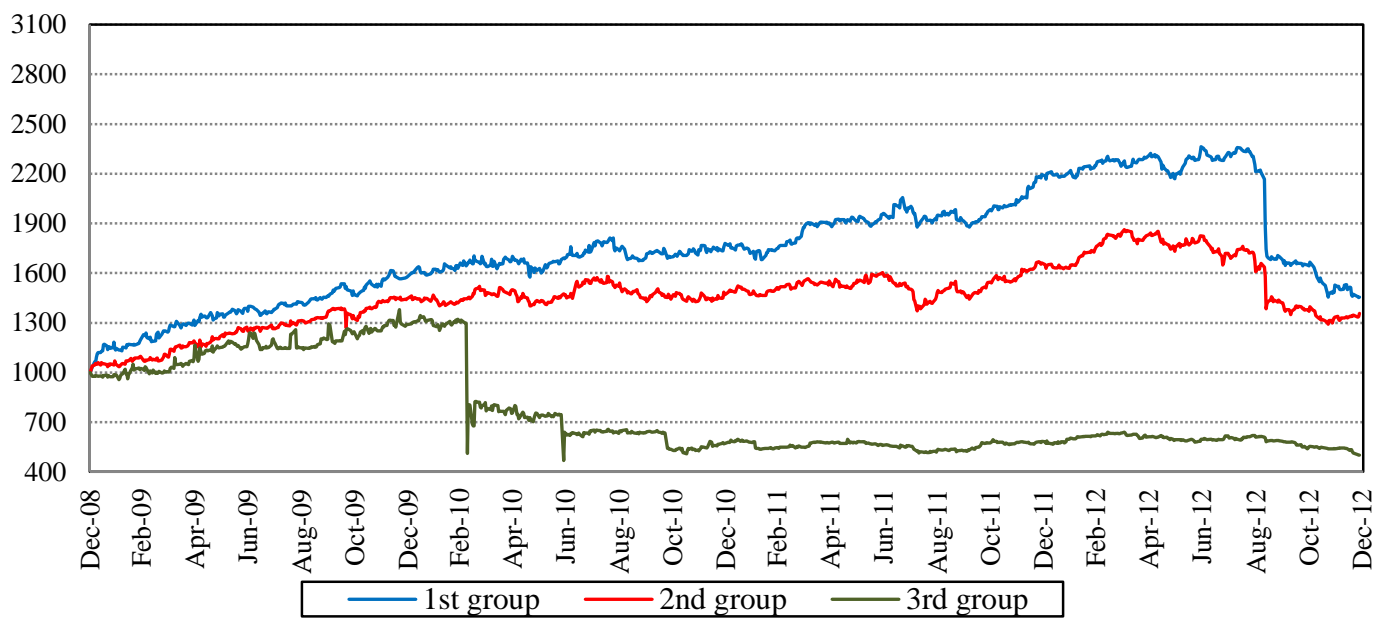

Source: Author's own.

Figure 18 - Portfolios B (2009-2012). Base fitted for 1000 points on 31/12/2008.

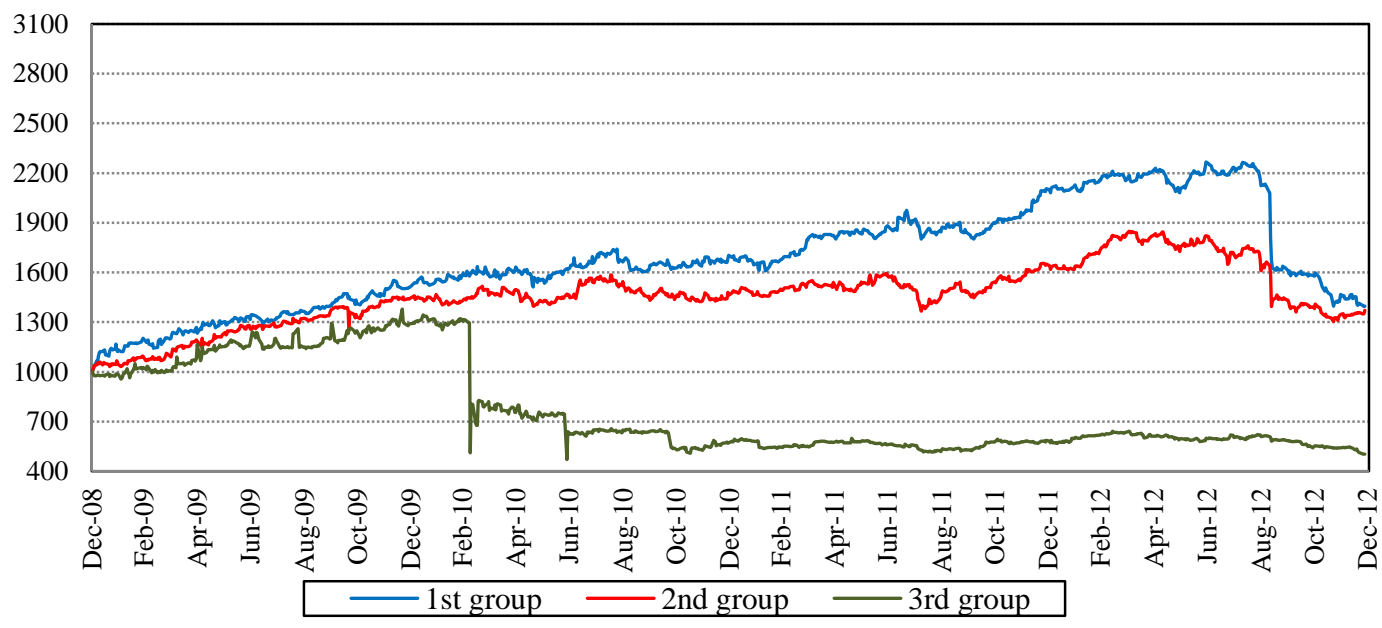

Source: Author's own. 
Figure 19 - Portfolios C (2009-2012). Base fitted for 1000 points on 31/12/2008.

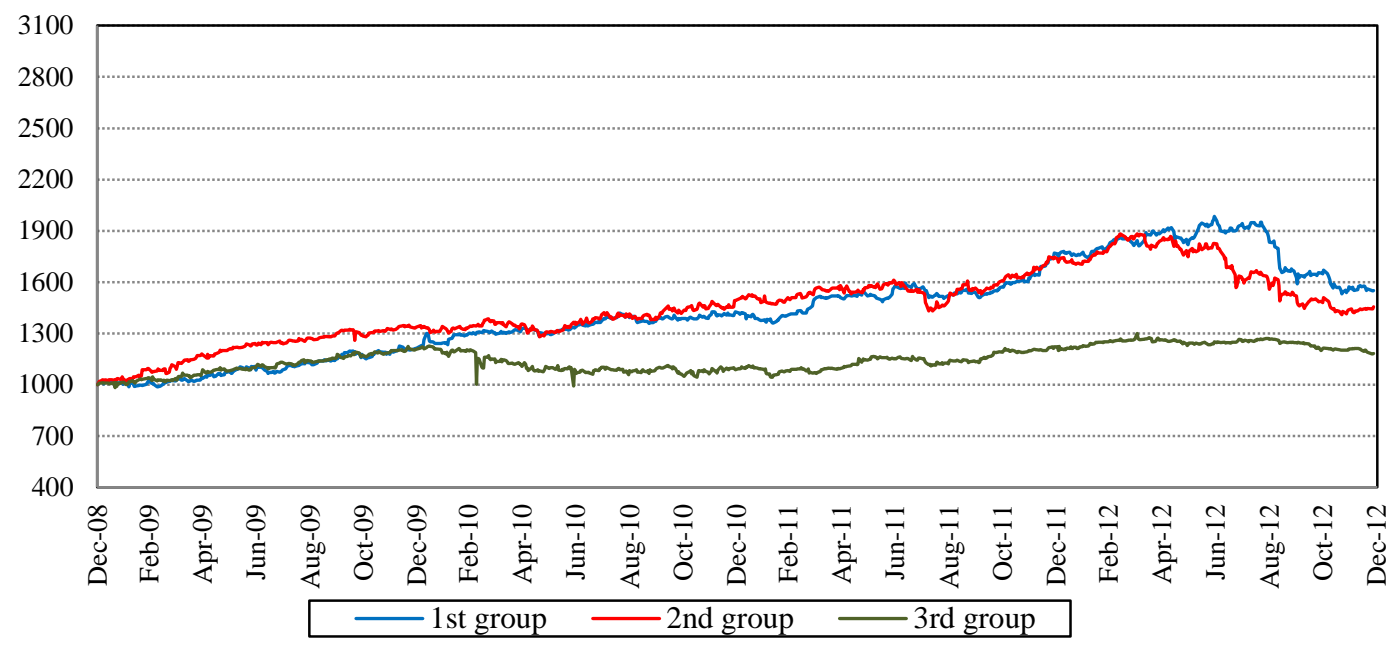

Source: Author's own.

Figure 20 - Portfolios D (2009-2012). Base fitted for 1000 points on 31/12/2008.

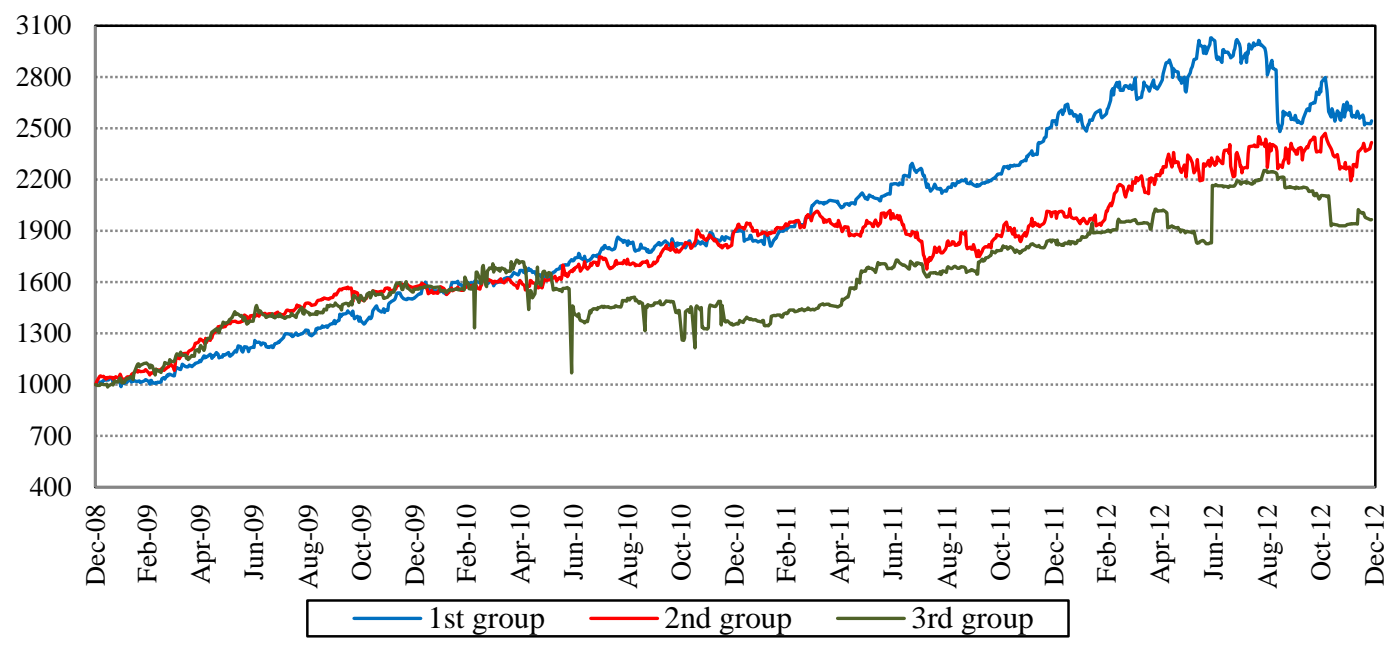

Source: Author's own.

\section{5}

\section{Ex-ante evaluation}

As previously reported, the results described in section 4.4 are derived from an ex-post analysis, where portfolios' performances are evaluated in the same year of their formation. This situation changes substantially when we investigate the ex-ante analysis, where market behaviour is not known a priori. In other words, in the ex-ante evaluation, portfolios' performances are assessed in the year following their formation. 


\subsection{1 \\ Preliminary data on risk-return composition}

Following the same metrics outlined in section 4.4.1, Table 7 below illustrates the results obtained in the ex-ante evaluation of formed portfolios using straightforward measures, such as annual expected return, annual volatility, coefficient of variation, beta and alpha.

Table 7 - Ex-ante evaluation: Preliminary data on risk-return composition

\begin{tabular}{|c|c|c|c|c|c|}
\hline & $\begin{array}{l}E[R] \\
\text { (p. a.) }\end{array}$ & $\begin{array}{c}\sigma \\
\text { (p. a.) }\end{array}$ & $\mathrm{CV}$ & $\beta$ & $\alpha$ \\
\hline IBOV & $-7.29 \%$ & $21.89 \%$ & -3.00 & 1.00 & 0.00 \\
\hline IEE & $1.94 \%$ & $15.27 \%$ & 7.88 & 0.44 & 0.00 \\
\hline ISE & $5.83 \%$ & $17.22 \%$ & 2.95 & 0.73 & 0.09 \\
\hline \multicolumn{6}{|c|}{ Portfolios A } \\
\hline $1^{\text {st }}$ group & $5.93 \%$ & $15.03 \%$ & 2.53 & 0.27 & 0.01 \\
\hline $2^{\text {nd }}$ group & $-1.98 \%$ & $15.79 \%$ & -7.98 & 0.30 & -0.06 \\
\hline $3^{\text {rd }}$ group & $-7.52 \%$ & $46.65 \%$ & -6.20 & 0.09 & -0.15 \\
\hline \multicolumn{6}{|c|}{ Portfolios B } \\
\hline $1^{\text {st }}$ group & $5.82 \%$ & $15.05 \%$ & 2.59 & 0.27 & 0.01 \\
\hline $2^{\text {nd }}$ group & $-1.32 \%$ & $15.90 \%$ & -12.08 & 0.30 & -0.06 \\
\hline $3^{\text {rd }}$ group & $-7.52 \%$ & $46.65 \%$ & -6.20 & 0.09 & -0.15 \\
\hline \multicolumn{6}{|c|}{ Portfolios C } \\
\hline $1^{\text {st }}$ group & $6.89 \%$ & $15.79 \%$ & 2.29 & 0.18 & 0.00 \\
\hline $2^{\text {nd }}$ group & $2.03 \%$ & $19.43 \%$ & 9.56 & 0.28 & -0.03 \\
\hline $3^{\text {rd }}$ group & $-1.55 \%$ & $38.10 \%$ & -24.58 & 0.03 & -0.11 \\
\hline \multicolumn{6}{|c|}{ Portfolios D } \\
\hline $1^{\text {st }}$ group & $6.43 \%$ & $18.98 \%$ & 2.95 & 0.26 & 0.01 \\
\hline $2^{\text {nd }}$ group & $-1.57 \%$ & $17.98 \%$ & -11.48 & 0.29 & -0.06 \\
\hline $3^{\text {rd }}$ group & $0.44 \%$ & $40.51 \%$ & 92.30 & 0.03 & -0.09 \\
\hline
\end{tabular}

Notes: p. a. stands for per annum.

Source: Author's own. 
Once again, the preliminary results from the ex-ante evaluation, as depicted in Table 7, clearly indicate that the best performances in terms of riskreturn trade-off were achieved in the first group portfolios, whose outcomes even surpassed those of the Brazilian Corporate Sustainability Index (ISE). Portfolios from the third group still seemed less susceptible to market fluctuations, as stated by their lowest betas. In return, they also presented the highest values of overall risk and the lowest expected returns, with the exception of the D class portfolio. The relative outlook, therefore, remained the same as in the ex-post evaluation. Nevertheless, in absolute terms, the overall performance of formed portfolios decreased substantially in the ex-ante evaluation. The vast majority did not even surpass the average annual returns of the risk-free $\operatorname{assets}^{9}(6.80 \%$ p. a. for the annual savings rate and $9.45 \%$ p. a. for the annual interbank deposit rate). However, it should be noted that the market as a whole presented poor performance, as observed by the negative average annual return of the IBOVESPA index (-7.29\% p.a.).

\subsection{2 \\ Financial performance indicators}

Following the same framework used in the ex-post evaluation, the exante performance results of each group portfolio in terms of Sharpe, Treynor and Jensen's measures are illustrated in Table 8. Table 9, in turn, lists their performances in terms of Sortino and Omega ratios.

As expected and anticipated by the results from Table 7 , the best performances in terms of the Sharpe ratio were once again achieved by the portfolios from the first group, followed by those from the second. This is most explicit in the first ShR column in Table 8, where the IBOVESPA index is used as the Sharpe ratio benchmark. In contrast, the ShR values illustrated in the second and third column are not readily comparable since the

\footnotetext{
${ }^{9}$ For calculation purposes and relative comparisons, the values for the annual savings rate (ASR) and the annual interbank deposit (CDI) rate are respectively as follows: $7.09 \%$ and $9.88 \%$ p. a. for $2009 ; 6.81 \%$ and $9.74 \%$ p. a. for $2010 ; 7.50 \%$ and $11.60 \%$ p. a. for $2011 ; 6.58 \%$ and $8.40 \%$ p. a. for 2012 ; and $6.32 \%$ and $8.06 \%$ p. a. for 2013 . Available on the following websites: http://portaldefinancas.com/cdi1213.htm http://www.portalbrasil.net/poupanca_mensal.htm
} 
Table 8 - Ex-ante - Sharpe, Treynor and Jensen measures (whole period)

\begin{tabular}{|c|c|c|c|c|c|c|c|c|}
\hline & \multicolumn{3}{|c|}{ ShR } & \multicolumn{3}{|c|}{ TrR } & \multicolumn{2}{|c|}{ JnR } \\
\hline & IBOV-based & ASR-based & CDI-based & IBOV-based & ASR-based & CDI-based & ASR-based & CDI-based \\
\hline IBOV & 0.000 & -0.644 & -0.765 & 0.000 & -0.141 & -0.167 & 0.000 & 0.000 \\
\hline IEE & 0.604 & -0.318 & -0.492 & 0.211 & -0.111 & -0.172 & 0.013 & -0.002 \\
\hline ISE & 0.762 & -0.056 & -0.210 & 0.180 & -0.013 & -0.050 & 0.093 & 0.086 \\
\hline \multicolumn{9}{|c|}{ Portfolios A } \\
\hline $1^{\text {st }}$ group & 0.880 & -0.058 & -0.234 & 0.489 & -0.032 & -0.130 & 0.029 & 0.010 \\
\hline $2^{\text {nd }}$ group & 0.336 & -0.556 & -0.724 & 0.175 & -0.290 & -0.378 & -0.045 & -0.064 \\
\hline $3^{\text {rd }}$ group & -0.005 & -0.307 & -0.364 & -0.026 & -1.600 & -1.895 & -0.131 & -0.155 \\
\hline \multicolumn{9}{|c|}{ Portfolios B } \\
\hline $1^{\text {st }}$ group & 0.871 & -0.065 & -0.241 & 0.480 & -0.036 & -0.133 & 0.029 & 0.009 \\
\hline $2^{\text {nd }}$ group & 0.376 & -0.510 & -0.677 & 0.202 & -0.275 & -0.365 & -0.040 & -0.058 \\
\hline $3^{\text {rd }}$ group & -0.005 & -0.307 & -0.364 & -0.026 & -1.600 & -1.895 & -0.131 & -0.155 \\
\hline \multicolumn{9}{|c|}{ Portfolios C } \\
\hline $1^{\text {st }}$ group & 0.898 & 0.006 & -0.162 & 0.796 & 0.005 & -0.144 & 0.026 & 0.004 \\
\hline $2^{\text {nd }}$ group & 0.480 & -0.246 & -0.382 & 0.339 & -0.173 & -0.270 & -0.009 & -0.028 \\
\hline $3^{\text {rd }}$ group & 0.151 & -0.219 & -0.289 & 2.102 & -3.057 & -4.027 & -0.080 & -0.105 \\
\hline \multicolumn{9}{|c|}{ Portfolios D } \\
\hline $1^{\text {st }}$ group & 0.723 & -0.019 & -0.159 & 0.538 & -0.014 & -0.118 & 0.032 & 0.013 \\
\hline $2^{\text {nd }}$ group & 0.319 & -0.465 & -0.613 & 0.194 & -0.284 & -0.374 & -0.042 & -0.061 \\
\hline $3^{\text {rd }}$ group & 0.191 & -0.157 & -0.222 & 2.819 & -2.321 & -3.287 & -0.060 & -0.086 \\
\hline
\end{tabular}

Source: Author's own. 
Table 9 - Ex-ante - Sortino and Omega ratios (whole period)

\begin{tabular}{ccccccc}
\hline \hline & \multicolumn{3}{c}{ SoR $\left(\mathrm{R}_{\min }\right)$} & \multicolumn{3}{c}{$\Omega\left(\mathrm{R}_{\min }\right)$} \\
& $\mathrm{R}_{\min }(-2,0 \%)$ & $\mathrm{R}_{\min }(0 \%)$ & $\mathrm{R}_{\min }(+2,0 \%)$ & $\mathrm{R}_{\min }(-2,0 \%)$ & $\mathrm{R}_{\min }(0 \%)$ & $\mathrm{R}_{\min }(+2,0 \%)$ \\
\hline \hline IBOV & 0.000 & 0.000 & 0.000 & 12.378 & 0.934 & 0.062 \\
IEE & 33.742 & 12.636 & 4.172 & 33.138 & 1.016 & 0.011 \\
ISE & 52.378 & 16.804 & 5.827 & 29.000 & 1.000 & 0.030 \\
\hline \hline & & & & & & \\
& & & & & & \\
\hline \hline & & & & & & \\
$1^{\text {st }}$ group & 54.637 & 19.203 & 6.042 & 38.600 & 0.930 & 0.025 \\
$2^{\text {nd }}$ group & 21.055 & 7.355 & 2.381 & 37.077 & 0.886 & 0.020 \\
$3^{\text {rd }}$ group & -0.127 & -0.111 & -0.076 & 20.522 & 0.807 & 0.050 \\
\hline \hline
\end{tabular}

Portfolios B

\begin{tabular}{ccccccc}
\hline \hline $1^{\text {st }}$ group & 53.369 & 18.967 & 5.989 & 38.600 & 0.937 & 0.025 \\
$2^{\text {nd }}$ group & 22.066 & 8.198 & 2.677 & 38.600 & 0.900 & 0.022 \\
$3^{\text {rd }}$ group & -0.127 & -0.111 & -0.076 & 20.522 & 0.807 & 0.050 \\
\hline \hline
\end{tabular}

Portfolios C

\begin{tabular}{ccccccc}
\hline \hline $1^{\text {st }}$ group & 58.094 & 21.907 & 6.546 & 51.105 & 0.976 & 0.015 \\
$2^{\text {nd }}$ group & 14.345 & 7.018 & 2.524 & 34.357 & 0.919 & 0.017 \\
$3^{\text {rd }}$ group & 3.757 & 3.367 & 2.100 & 51.105 & 0.817 & 0.019 \\
\hline \hline & & & & & \\
& & & Portfolios D & & \\
\hline \hline $1^{\text {st }}$ group & 38.086 & 16.164 & 5.999 & 21.500 & 0.941 & 0.042 \\
$2^{\text {nd }}$ group & 15.566 & 6.644 & 2.493 & 25.053 & 0.964 & 0.023 \\
$3^{\text {rd }}$ group & 4.983 & 4.266 & 2.703 & 33.138 & 0.758 & 0.033 \\
\hline \hline
\end{tabular}

Notes: Sortino ratios in ex-ante evaluation are IBOVESPA-based.

Source: Author's own.

Sharpe ratio is awkward to interpret when it is negative. The same goes for the Treynor ratio. Therefore, for relative comparison purposes, we stick to the ShR and TrR values obtained using the IBOVESPA index as benchmark.

With regard to the Treynor ratio, first group portfolios presented the best results in the first two scenarios (A and $\mathrm{B}$ ), followed by those from the second group. Conversely, third group portfolios outperformed the others in scenarios $\mathrm{C}$ 
and D. Yet this is mainly attributed to the fact that portfolios from the third group are less susceptible to market fluctuations (lower betas) and not to their performances in terms of expected returns.

Finally, concerning the Jensen's alpha, the best performances were returned by the first group portfolios, followed by those from the second group, irrespective of the scenario.

Turning to the results from Table 9, there is no question that portfolios from the first group clearly outpaced the others in terms of higher premiums per unit of downside risk, irrespective of the selected threshold $\left(\mathrm{R}_{\min }\right)$. Portfolios from the second group, in turn, also presented considerably higher Sortino ratios than those from the third group. Hence, socially responsible portfolios continued to present lower probabilities of large losses in the ex-ante evaluation. Albeit this does not invalidate the overall findings, it should be stressed that SoR values depicted in Table 9 are IBOVESPA-based, i.e., they were calculated using the IBOVESPA index as the benchmark (contrary to SoR values calculated in the expost evaluation, which were CDI-based). This was just to avoid relative comparisons using negative Sortino ratios since most portfolios in the ex-ante case did not present average annual returns higher than the risk-free assets but performed considerably better than the IBOVESPA index.

With regard to the Omega ratio, the best results when the threshold is set to $0 \%$ (a common basis of comparison) were achieved in the first group portfolios for cases $\mathrm{A}$ to $\mathrm{C}$ and in the second group portfolio for the last case. Once again, third group portfolios presented a small advantage if one considers the probability of obtaining a return superior to $2 \%$, which is quite uncommon in practice. Furthermore, it can be noted that this apparent superiority concerning third group portfolios only starts to appear at considerably higher thresholds, with larger Omega ratios prevailing for first and second group portfolios in the majority of cases. The sensitivity of the Omega measure results in relation to the minimum expected threshold $\left(\mathrm{R}_{\min }\right)$ for ex-ante evaluation can be found in Appendix $\mathrm{H}$.

Finally, for a straightforward view, Figure 21 below summarises the overall ex-ante results in terms of all five financial metrics (radar charts). Values for ShR, TrR and JnR are CDI-based and SoR values are IBOVESPA-based. 
Figure 21 - Indices and firm groups ex-ante performances (whole period)

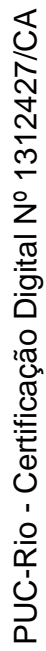

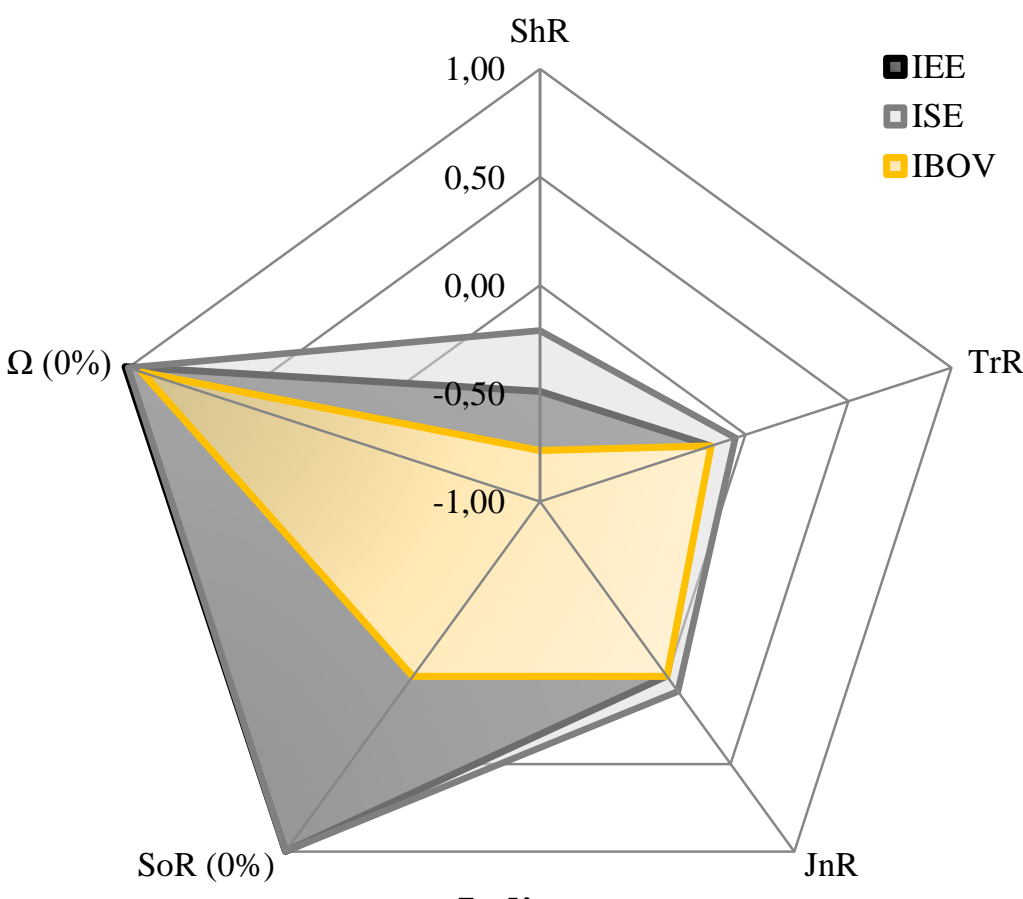

Indices

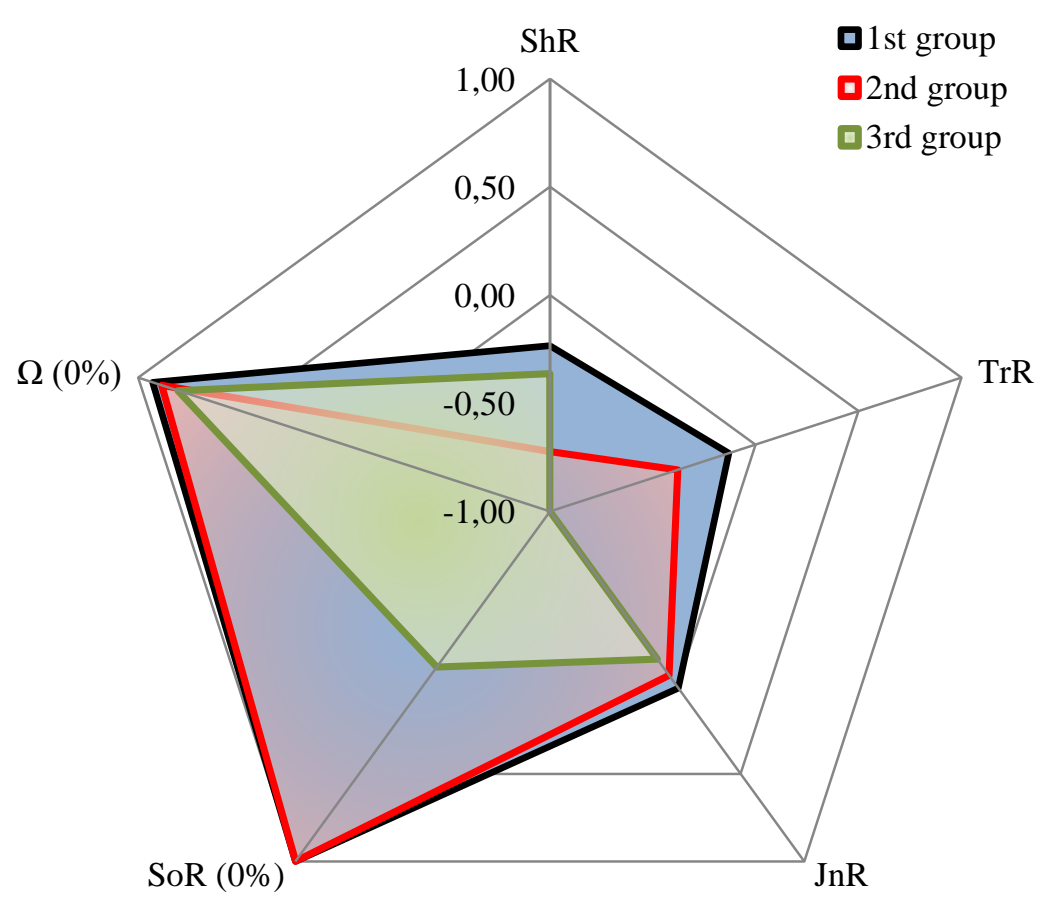

Portfolios A 


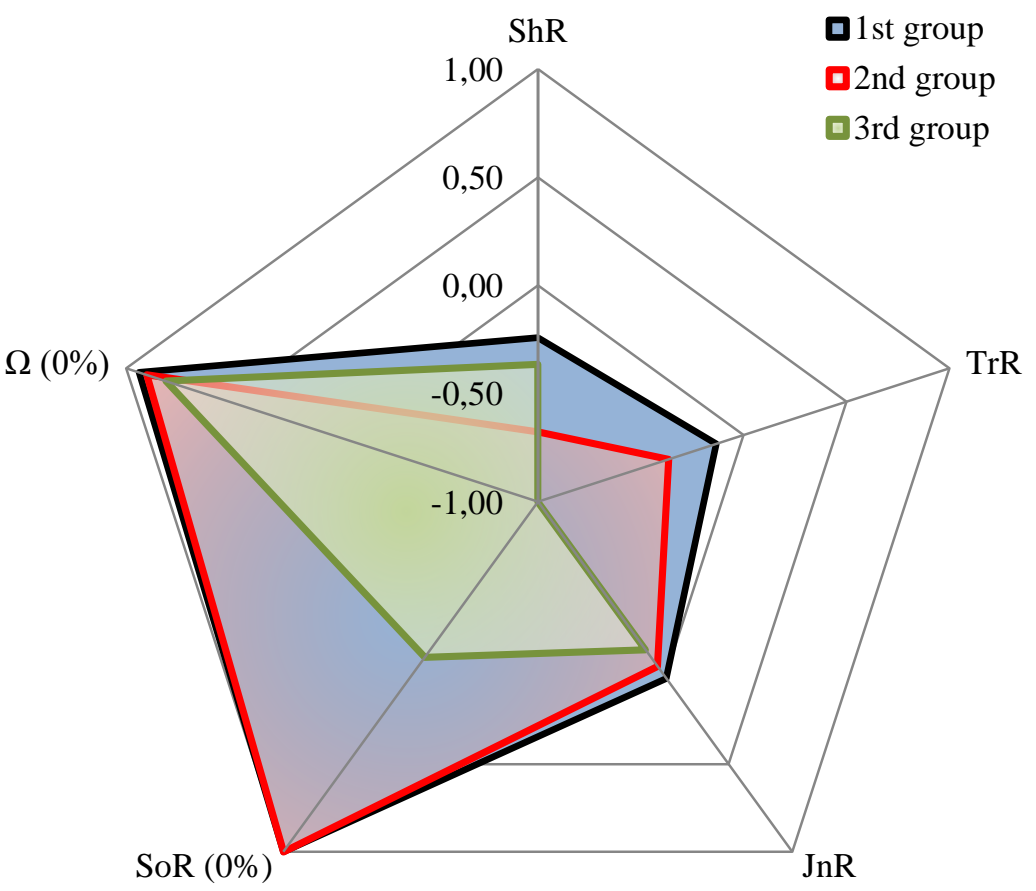

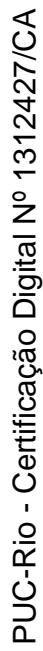

\section{Portfolios B}

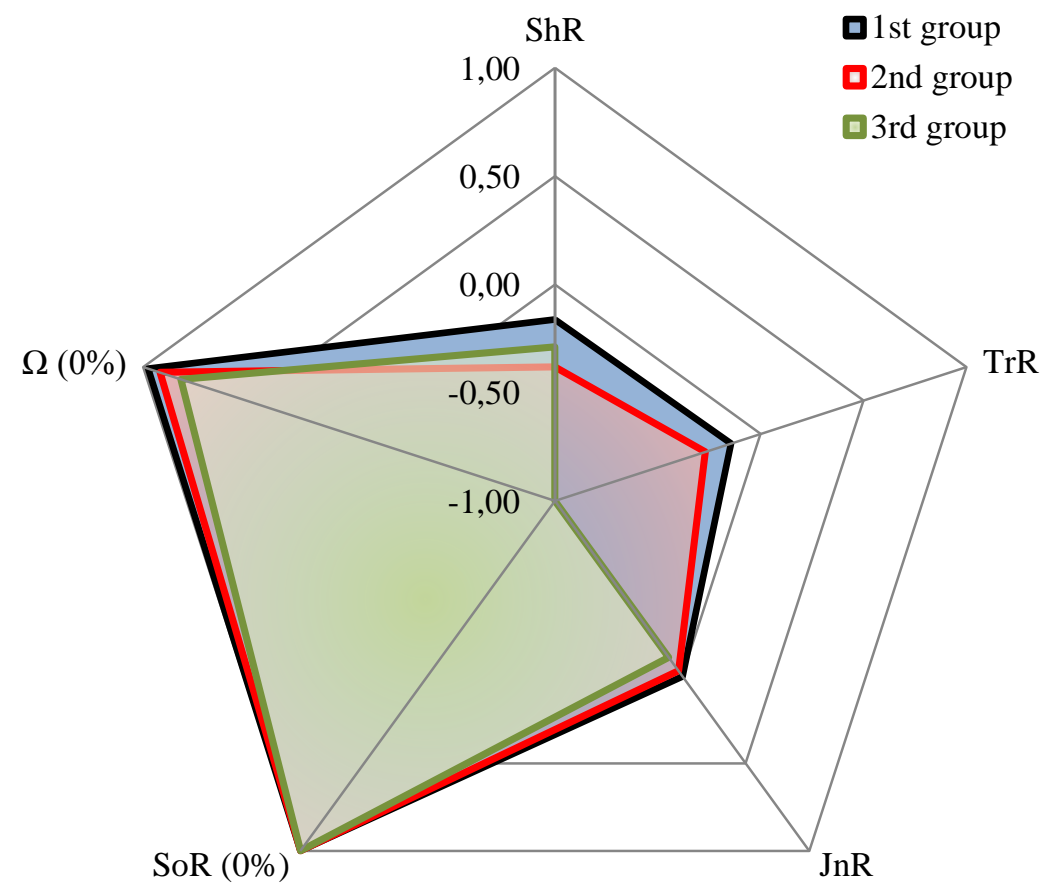

Portfolios C 


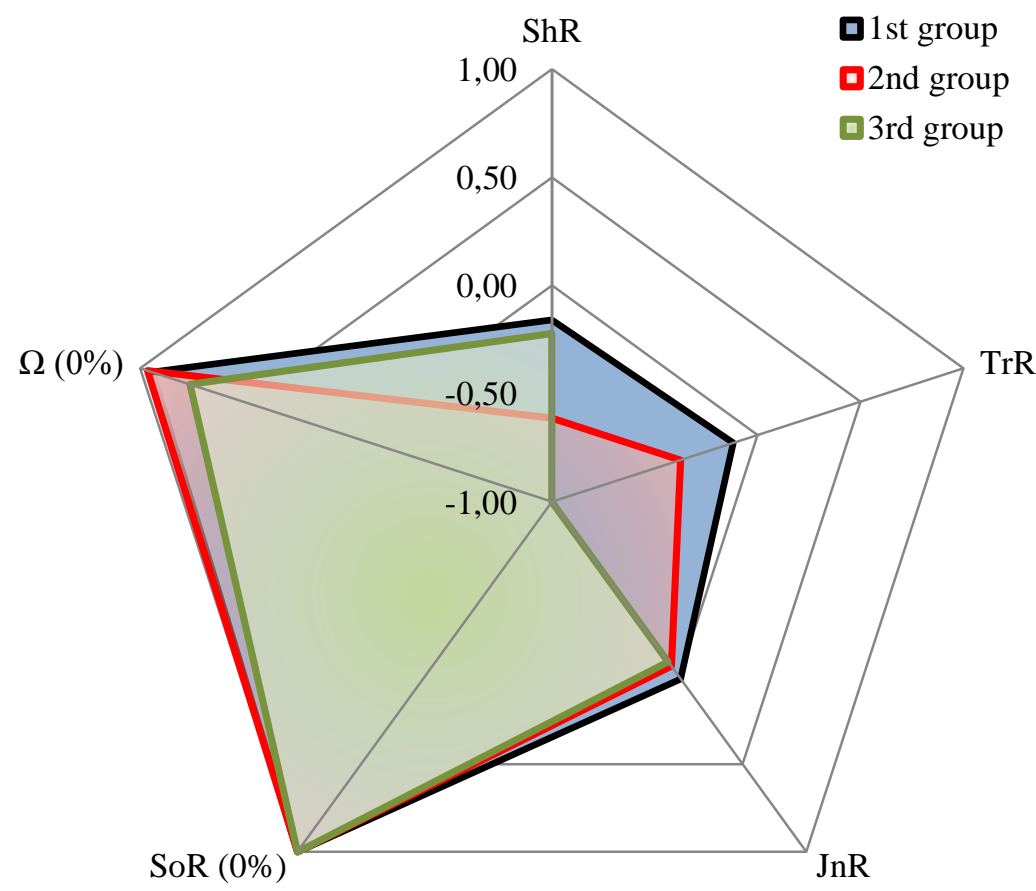

Portfolios D

Source: Author's own.

Once again, there is no dispute that best ex-ante results were achieved in the first group portfolios, followed by those from the second group. Hence, socially responsible portfolios in the Brazilian electric sector not only offered higher excess returns per unit of risk but also presented lower probabilities of large losses in both ex-ante and ex-post assessments.

\subsection{3}

\section{Financial behaviour over the years}

Figure 22 shows the IBOVESPA, IEE and ISE indices historical data for the period spanned from January 2010 to December 2013. The base period is set at $2010=1000$. In a similar fashion, the ex-ante behaviour of each group portfolio in scenarios A to D are illustrated in Figures 23 to 26, respectively.

According to these graphs, during the greater part of the ex-ante analysis period, first group portfolios were the only ones that remained above the reference 
value of 1000. Following the behaviour of the electric power index (IEE), their performances were considerably high until the first half of 2012 and then plummeted in the remainder of the year. Even so, their overall results outpaced even those of the Brazilian Corporate Sustainability Index (ISE).

It is also quite clear that portfolios from the second group performed substantially better than those from the third group, with the possible exception of the D class portfolios, where both groups presented very similar outcomes.

Finally, it is worth noting that the negative relationship between the electric sector and the Brazilian market as a whole, which prevailed during the greater part of the ex-post period, was not sustained in 2013, where both IEE and IBOVESPA indices presented compatible results in terms of daily returns and volatilities.

Figure 22 - IBOVESPA, IEE and ISE historical data (2010-2013). Base fitted for 1000 points on $31 / 12 / 2009$.

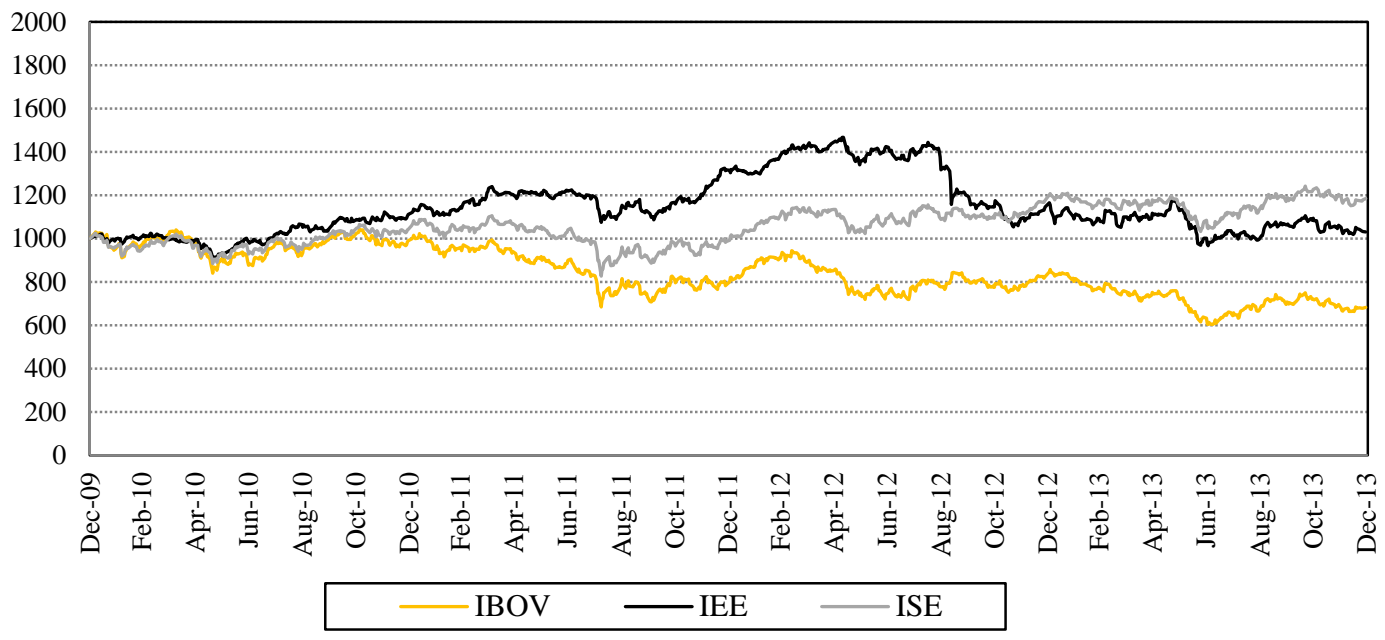

Source: BM\&FBOVESPA (2014).

Figure 23 - Portfolios A (2010-2013). Base fitted for 1000 points on 31/12/2009. 


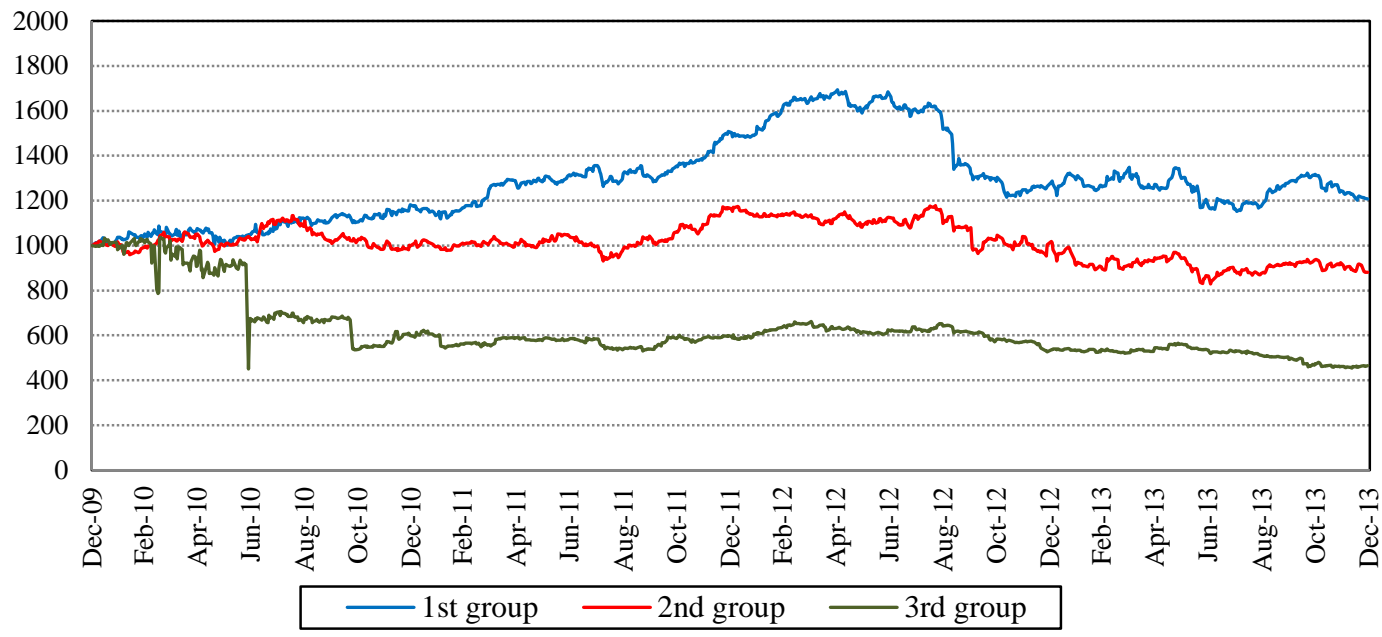

Source: Author's own.

Figure 24 - Portfolios B (2010-2013). Base fitted for 1000 points on 31/12/2009.

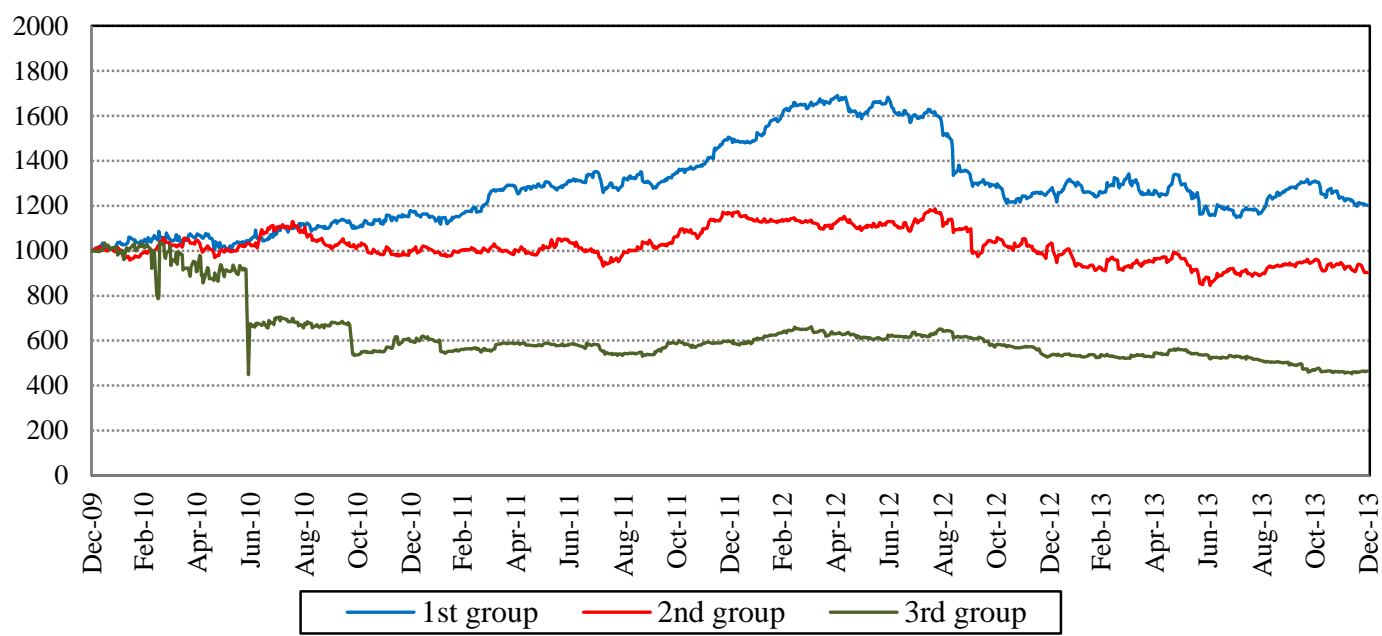

Source: Author's own.

Figure 25 - Portfolios C (2010-2013). Base fitted for 1000 points on 31/12/2009.

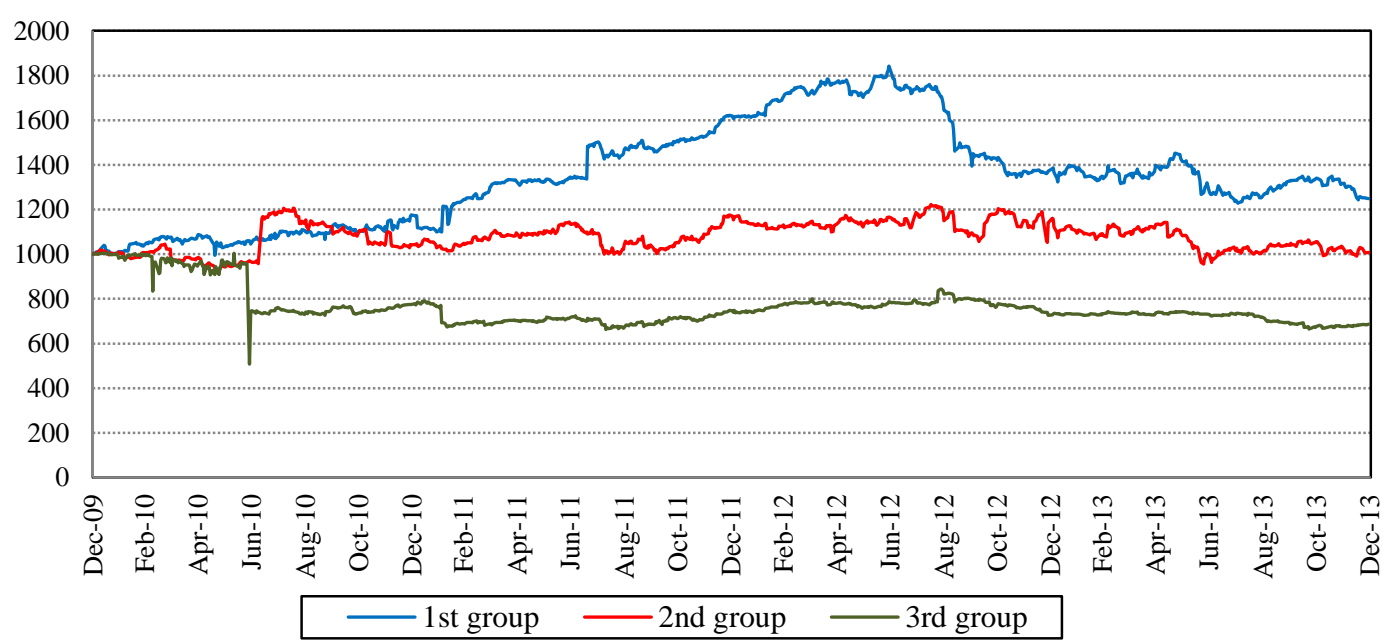

Source: Author's own. 
Figure 26 - Portfolios D (2010-2013). Base fitted for 1000 points on 31/12/2009.

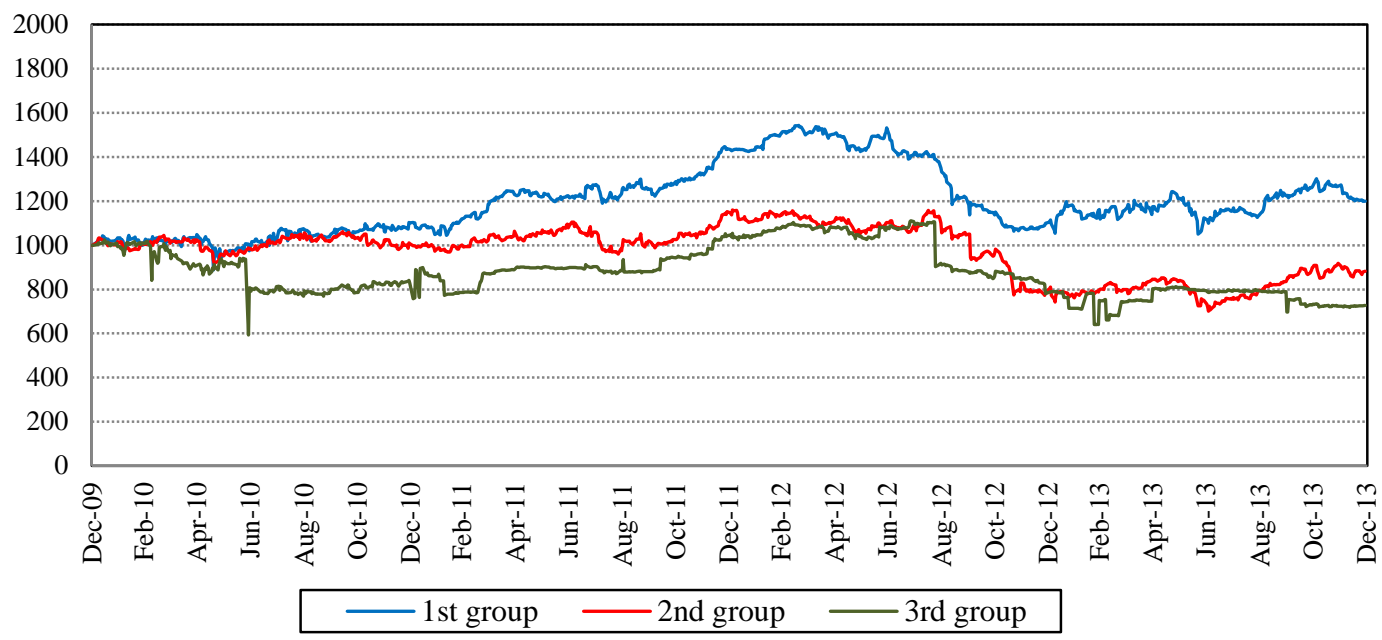

Source: Author's own.

\section{6 \\ Discussion}

The findings from this study carry numerous important implications for many different stakeholders, at least in the Brazilian electric sector. From the firms' perspective, even though managers may decide to avoid engaging in socially responsible activities based solely on their values and beliefs, the results of this study suggest that such activities can also have a strong economic rationale in certain conditions of earning profit and serving society. For consumers increasingly reaching for "green" or "fair trade products", being aware that the market somehow "remunerates" socially responsible behaviour is definitely an extra boost. Finally, from an academic standpoint, although one cannot readily extrapolate findings from this study to other sectors of the Brazilian economy, the results obtained from the ex-post and ex-ante evaluation clearly indicate that the involvement of Brazilian electric companies in CSR practices and their financial outcomes are in line with what Freeman's (1984) stakeholders theory claims, where firms fulfilling their fiduciary duty to society and disseminating their social outcomes to the general public typically performs better than those that do not invest in socially responsible practices nor produce social reports.

Like all empirical research, our study has several limitations that one needs to bear in mind while interpreting its results. First, as extensively outlined 
in previous chapters, measurement is always a major issue when studying CSR. Despite strenous efforts to take into account all dimensions of CSR using ESG disclosures scores, one should not rely blindly on DEA efficient scores and expect that such measures can be applied to every case scenario. Second, the number of Brazilian firms already publishing social reports in an annual basis is still low. In addition, the sample of this study was narrowly defined to include a fairly homogeneous set of firms, i.e., sector-based. Third, our study did not control for potential industry effects that could influence relationships between the variables. Finally, given the long-term orientation of socially responsible practices, successful CSR investments may result from a longer time horizon. This is especially true when examining the relevance of intangible assets, such as reputation and knowledge networks, which can turn into a source of market value and a competitive advantage.

Even so, given the scarcity of reliable data which prevails in this field and considering that CSR disclosure is not yet widespread in Brazil, it was quite clear that firms with the best environmental, social and corporate governance (ESG) practices performed significantly better in the Brazilian financial market than their counterparts during the years of the analysis. Portfolios comprising only assets from firms with the best ESG practices not only offered higher excess returns per unit of risk but also presented lower probabilities of large losses in both ex-post and ex-ante evaluations. In addition, electric firms that presented lower ESG performances but, at the same time, released social annual reports during the years of 2009 to 2012 performed significantly better in the Brazilian financial market than firms that did not disclose any social information within this time span. It is thus reasonable to say that there has been indeed a positive relationship between a firm's efforts to become more socially responsible and its financial performance, at least in the Brazilian electric sector. 


\section{5 \\ Conclusions and final remarks}

The relationship between corporate social responsibility and financial performance has engendered considerable interest in recent years. In this regard, a growing body of research has shown that certain firms have responded to these concerns by devoting more resources to CSR. In their view, following Freeman's (1984) stakeholders theory, CSR can be a proactive business strategy and an effective marketing tool to create and sustain a competitive advantage. On the other hand, in some organisations, management has resisted to respond to CSR pressures. In line with Friedman's (1970) shareholders theory, these firms allege that CSR investments are inconsistent with efforts to maximise profits. Further, recent thinking in this field has also suggested that, regardless of the prevailing opinion on shareholders or stakeholders theory, when social initiatives are not aligned with business objectives, CSR becomes a liability and diminishes previously held beliefs among customers about firms (LIN et al., 2009; BARNETT and SOLOMON, 2012). This disagreement has prompted researchers to examine the relationship between CSR and financial performance in an effort to assess the validity of these concerns. The results of several empirical studies, however, have often been inconclusive.

In light of the above, this work makes a significant contribution to the never-ending debate on the relationship between CSR and firm performance, although restricted to the Brazilian electric sector in recent years. The findings strongly suggest that the involvement of Brazilian electric companies in CSR practices and their financial outcomes possibly match with what Freeman's (1984) stakeholder theory claims, where firms fulfilling their fiduciary duty to society and disseminating their social outcomes to the general public typically performs better than those that do not invest in sustainable practices nor produce social reports. It should be stressed, though, that the results were taken for a specific time period and there may be significant differences when other dates are taken into account. 
In general, it can be stated that the objectives that had been proposed were met. In spite of the scarcity of reliable data and considering that CSR disclosure is not yet widespread in Brazil, it was still possible to establish coherent and consistent criteria to classify firms according to their current efforts to become more socially responsible; form different groups of portfolios based on companies' ESG efficiency values; and assess their financial performances, drawing intelligible comparisons among portfolios and between portfolios and the IBOVESPA, IEE and ISE indices. It is worth emphasising yet again that, although there is a growing view among investment professionals that CSR issues can affect firm performance, one of the main criticisms addressed to emerging markets has been the lack of a coherent set of metrics to assess CSR. In this context, this work can also be regarded as innovative since it analysed hitherto unexplored areas of CSR reporting, such as information from firms' social reports, and proposed a multidimensional framework to evaluate companies' efforts to become more socially responsible.

Finally, albeit one cannot readily extrapolate findings from this study to other sectors of the economy, we expect that the applied methodology could find widespread application to other Brazilian industry sectors in the mid-term, provided that more firms adhere to social reporting practices in the near future. It is also worth noting that other methods may be proposed to investigate the relationship between CSR and financial performances, and that the selection of performance indicators is linked to a wide variety of criteria. 


\section{References}

ACKERMAN, R. W. The Social Challenge to Business. 1st ed. Cambridge, Mass.: Harvard University Press, 1975. 345 p.

AKAIKE, H. A new look at the statistical model identification. IEEE Transactions on Automatic Control, v. 19, n. 6, p. 716-723, 1974.

ALI, A. I.; SEIFORD, L. M. The Mathematical Programming Approach to Efficiency Analysis. In: FRIED, H. O.; LOVELL, C. A. K.; SCHIMIDT, S. S. (eds.). The Measurement of Productive Efficiency: Techniques and Applications. Oxford, UK : Oxford University Press, 1993. p. 120-159.

AMENC, N.; MARTELLINI, L. Portfolio optimization and hedge fund style allocation decisions. The Journal of Alternative Investments, v. 5, n. 2, p. 7-20, 2002.

ANDERSON, J. C.; FRANKLE, W. Voluntary social reporting: An iso-beta portfolio analysis. The Accounting Review, v. 55, n. 3, p. 467-479, 1980.

ANDREW, B. H.; GUL, F. A.; GUTHRIE, J. E.; TEOH, H. Y. A note on corporate social disclosure practices in developing countries: the case of Malaysia and Singapore. British Accounting Review, v. 16, n. 1, p. 12-26, 1989.

ARNOLD, V.; BARDHAN, I.; COOPER, W. W.; GALLEGOS, A. Primal and dual optimality in computer codes using two-stage solution procedures in DEA. In: ARONSON, J.; ZIONTS, S. (eds.). Operations Research: Methods, models and applications. 1st ed. Boston: Kluwer Academic Publishers, 1998. 374 p.

BANKER, R. D.; CHARNES, A.; COOPER, W. W. Some models for estimating technical and scale inefficiencies in data envelopment analysis. Management Science, v. 30, n. 9, p. 1078-1092, 1984.

BANKER, R. D.; COOPER, W. W.; SEIFORD, L. M.; ZHU, J. Returns to scale in DEA. In: COOPER, W. W.; SEIFORD, L. M.; ZHU, J. (eds.). Handbook on Data Envelopment Analysis. International Series in Operations Research \& Management Science, v. 164, Chapter 2, p. 41-70, 2011.

BANKER, R. D.; THRALL, R. M. Estimation of returns to scale using Data Envelopment Analysis. European Journal of Operational Research, v. 62, n. 1, p. 74-84, 1992.

BARNETT, M. L.; SALOMON, R. M. Does it pay to be really good? Addressing the shape of the relationship between social and financial performance. Strategic Management Journal, v. 33, n. 11, p. 1304-1320, 2012.

BELAL, A. R. A Study of Corporate Social Disclosures in Bangladesh. Managerial Auditing Journal, v. 16, n. 5, p. 274-289, 2001.

BELKAOUI, A. The impact of the disclosure of the environmental effects of organizational behavior on the market. Financial Management, v. 5, n. 4, p. 2631, 1976. 
BERTRAND, P.; PRIGENT, J-L. Omega performance measure and portfolio insurance. Journal of Banking and Finance, v. 35, n. 7, p. 1811-1823, 2011.

BEUREN, I. M.; NASCIMENTO, S.; ROCHA, I. Nível de evidenciação ambiental e desempenho econômico de empresas: Aplicando a análise envoltória de dados. Future Studies Research Journal, v. 5, n. 1, p. 198-226, 2013.

BLACK, F. Capital Market Equilibrium with Restricted Borrowing. Journal of Business, v. 45, n. 3, p. 444-454, 1972.

BLOOMBERG. Bcause Impact Report 2013 Update. New York: Bloomberg L. P., 2013. 37p.

BRAZILIAN INSTITUTE OF APPLIED ECONOMIC RESEARCH (IPEA). Bondade ou interesse? Como e por que as empresas atuam na área social. $1 \mathrm{st}$ ed. Brasília: IPEA, 2001. 103 p.

BRAZILIAN INSTITUTE OF SOCIAL AND ECONOMIC ANALYSIS (IBASE). Balanço social, dez anos: O desafio da transparência. 1st ed. Rio de Janeiro: IBASE, 2008. 96 p.

BRAZILIAN MERCANTILE, FUTURES AND STOCK EXCHANGE (BM\&FBOVESPA). 2013. BM\&FBOVESPA's Sustainability Policy. Available at http://www.bmfbovespa.com.br/en-us/download/Politica-Final-REVISADAINGLES.pdf. Accessed May 20, 2014.

BRAZILIAN MERCANTILE, FUTURES AND STOCK EXCHANGE (BM\&FBOVESPA) site. Available at: <http://www.bmfbovespa.com.br/>. Accessed May 22, 2014.

BOWEN, H. R. Social responsibilities of the businessman. 1st ed. New York: Harper\&Row, 1953. 276 p.

BRAZILIAN FEDERAL ACCOUNTING COUNCIL (CFC). Resolução CFC no 1003/2004. Aprova a NBC T 15 - Informações de Natureza Social e Ambiental. Available at: http://www.cfc.org.br/sisweb/sre/detalhes_sre.aspx?Codigo=2004/001003. Accessed September 24, 2014.

BRAZILIAN MINISTRY OF ENVIRONMENT (MMA). Meio ambiente: brasileiro está mais consciente. 2012. Available at: http://www.mma.gov.br/informma/item/8386-o-que-o-brasileiro-pensa-do-meioambiente-e-do-consumo-sustent\%C3\%A1vel. Accessed September 23, 2014.

BROMILEY, P.; MARCUS, A. The deterrent to dubious corporate behavior: Profitability, probability, and safety recalls. Strategic Management Journal, v. 10, n. 3, p. 233-250, 1989.

CARROLL, A. B. A three-dimensional conceptual model of corporate social performance. Academy of Management Review, v. 4, n. 4, p. 497-505, 1979.

CARROLL, A. B. Corporate social responsibility: Will industry respond to cutbacks in social program funding? Vital Speeches of the Day, v. 49, p. 604608, 1983.

CARROLL, A. B. The pyramid of corporate social responsibility: Toward the moral management of organizational stakeholders. Business Horizons, v. 34, n. 4, p. 39-48, 1991.

CARROLL, A. B. Corporate social responsibility: evolution of a definitional construct. Business Society, v. 38, n. 3, p. 268-295, 1999. 
CAVAlCANTE, L. R. M. T.; BRUNI, A. L.; COSTA, F. J. M. Sustentabilidade empresarial e valor das ações: uma análise na bolsa de valores de São Paulo. Revista de Gestão Social e Ambiental, v. 3, n. 1, p. 70-86, 2009.

CENTER FOR RESEARCH IN SECURITY PRICES (CSRP) site. Available at: $<$ http://www.crsp.com/products/documentation/crsp-calculations $>$. Accessed June 30, 2014.

CHOPRA, V. K.; ZIEMBA, W. T. The effect of errors in means, variances, and covariances on optimal portfolio choice. The Journal of Portfolio Management, v. 19, n. 2, p. 6-11, 1993.

CLARKE, R.; DE SILVA, H.; THORLEY, S. Minimum-Variance Portfolio Composition. The Journal of Portfolio Management, v. 37, n. 2, p. 31-45, 2011.

COELli, T. J.; RAO, D. S. P.; O'DONNELL, C. J.; BATTESE, G. E. An introduction to efficiency and productivity analysis. 2nd ed. New York: Springer Science+Business Media, Inc., 2005. 331 p.

COMMITTEE FOR ECONOMIC DEVELOPMENT. Social responsibilities of business corporations. 1st ed. Washington, DC: Charles Allen \& Company, Inc, 1971. $61 \mathrm{p}$.

CHARNES, A.; COOPER, W. W. Programming with linear fractional functionals. Naval Research Logistics Quarterly, v. 9, n. 3-4, p. 181-186, 1962.

CHARNES, A.; COOPER, W. W.; RHODES, E. Measuring the efficiency of decision making units. European Journal of Operational Research, v. 2, n. 6, p. 429-444, 1978.

COFFEY, B. S.; FRYXELL, G. E. Institutional ownership of stock and dimensions of corporate social performance: An empirical examination. Journal of Business Ethics, v. 10, n. 6, p. 437-444, 1991.

COHEN, M. A.; FENN, S. A.; KONAR, S. Environmental and financial performance: Are they related? 1st ed. Washington, D. C.: Investor Responsibility Research Center, Environmental Information Service, 1997. 27 p.

COOPER, W. W.; SEIFORD, L. M.; ZHU, J. Data envelopment analysis: History, models, and interpretations. In: COOPER, W. W.; SEIFORD, L. M.; ZHU, J. (eds.). Handbook on Data Envelopment Analysis. International Series in Operations Research \& Management Science, v. 164, Chapter 1, p. 1-39, 2011.

CORMIER, D.; MAGNAN, M., VAN VELTHOVEN, B. Environmental disclosure quality in large German companies: Economic incentives, public pressures or institutional conditions? European Accounting Review, v. 14, n. 1, p. 3-39, 2005.

COWEN, S. S.; FERRERI, L. B.; PARKER, L. D. The impact of corporate characteristics on social responsibility disclosure: A typology and frequencybased analysis. Accounting Organizations and Society, v. 12, n. 2, p. 111-122, 1987.

CRISÓSTOMO, V. L.; FREIRE, F. S.; PARENTE, P. H. N. An analysis of corporate social responsibility in Brazil: Growth, firm size, sector and internal stakeholders involved in policy definition. Pensamiento y Gestión, v. 37, p. 126$150,2014$. 
CUNHA, F. A. F. S.; SAMANEZ, C. P. Performance analysis of sustainable investments in the brazilian stock market: A study about the corporate sustainability index (ISE). Journal of Business Ethics, v. 117, n. 1, p. 19-36, 2013.

DAVIDSON, W. N.; CHANDY, P. R.; CROSS, M. Large losses, risk management and stock returns in the airline industry. The Journal of Risk and Insurance, v. 54, n. 1, p. 162-172, 1987.

DAVIDSON, W. N.; WORRELL, D. L. The impact of announcements of corporate illegalities on shareholder returns. The Academy of Management Journal, v. 31, n. 1, p. 195-200, 1988.

DAVIS, K. Can business afford to ignore social responsibilities? California Management Review, v. 2, n. 3, p. 70-76, 1960.

DAVIS, K.; BLOMSTROM, R. L. Business and its environment. 1st ed. New York: McGraw-Hill, 1966. 403 p.

DEAL, T. E.; KENNEDY, A. A. Corporate cultures: The rites and rituals of corporate life. 1st. ed. Reading, Mass.: Addison-Wesley, 1982. 232 p.

DEBREU, G. The coefficient of resource utilization. Econometrica, v. 19, n. 3, p. 273-292, 1951.

DERWALL, J.; GUENSTER, N.; BAUER, R.; KOEDIJK, K. The eco-efficiency premium puzzle. Financial Analysts Journal, v. 61, n. 2, p. 51-63, 2005.

DICKEY, D. A.; FULLER, W. A. Distribution of the estimators for autoregressive time series with a unit root. Journal of the American Statistical Association, v. 74, n. 366, p. 427-431, 1979.

DILTZ, J. D. Does social screening affect portfolio performance? The Journal of Investing, v. 4, n. 1, p. 64-69, 1995.

DONALDSON, T. The Ethics of International Business. 1st ed. New York: Oxford University Press, 1991. 200 p.

DONALDSON, T.; DUNFEE, T. W. Toward a unified conception of business ethics: integrative social contracts theory. Academy of Management Review, v. 19, n. 2, p. 252-284, 1994.

DONALDSON, T.; PRESTON, L. The Stakeholder Theory of the Corporation: Concepts, Evidence, and Implications. Academy of Management Review, v. 20, n. 1, p. 65-91, 1995.

DOUGLAS, M. Integrative Social Contracts Theory: Hype over hypernorms. Journal of Business Ethics, v. 26, n. 2, p. 101-110, 2000.

DOWLING, J.; PFEFFER, J. Organizational Legitimacy: Social Values and Organizational behavior. The Pacific Sociological Review, v. 18, n. 1, p. 122136, 1975.

DUNFEE, T. W. A critical perspective of Integrative Social Contracts Theory: Recurring criticisms and next generation research topics. Journal of Business Ethics, v. 68, n. 3, p. 303-328, 2006.

EELLS, R. Corporation giving in a free society. 1st ed. New York: Harper \& Bros., 1956. 210p. 
ENVIRONICS INTERNATIONAL. The millennium poll on Corporate Social Responsibility: Executive brief. Toronto: Environics International Ltd., 1999. 5p.

EPSTEIN, E. M. The corporate social policy process: Beyond business ethics, corporate social responsibility, and corporate social responsiveness. California Management Review, v. 29, p. 99-114, 1987.

ERNST AND ERNST. Social Responsibility Disclosure, 1978 Survey. Cleveland: Ernst and Ernst, 1978.

FAMA, E. F.; MACBETH, J. D. Risk, return and equilibrium: empirical tests. The Journal of Political Economy, v. 81, n. 3, p. 607-636, 1973.

FÄRE, R.; LOVELL; C. A. K. Measuring the technical efficiency of production. Journal of Economic Theory, v. 19, n. 1, p. 150-162, 1978.

FARRELL, M. J. The measurement of productive efficiency. Journal of the Royal Statistical Society, Series A (General), v. 120, n. 3, p. 253-290, 1957.

FAVRE-BULLE, A.; PACHE, S. The Omega measure: hedge fund portfolio optimization. 2003. 45p. Master's dissertation (Master of Science in Banking and Finance) - Faculté des Hautes Études Commerciales (École des HEC), University of Lausanne, Lausanne, 2003.

FERRIER, G. D.; LOVELL, C. A. K. Measuring cost efficiency in banking: Econometric and linear programming evidence. Journal of Econometrics, v. 46, n. 1-2, p. 229-245, 1990.

FORT, T. L.; SCHIPANI, C. A. A Symposium on corporate governance, stakeholder accountability, and sustainable peace. Vanderbilt Journal of Transnational Law, v. 35, n. 2, p. 379-388, 2002.

FREDERICK, W. C. The growing concern over business responsibility. California Management Review, v. 2, n. 4, p. 54-61, 1960.

FREDERICK, W. C. Corporate social responsibility : deep roots, flourishing growth, promising future. In: CRANE, A. W.; MCWILLIAMS, A.; MATTEN, D.; MOON, J.; SIEGEL, D. S. (eds.). The Oxford Handbook of Corporate Social Responsibility. Oxford, UK: Oxford University Press, 2008, p. 522-531.

FREEDMAN, M.; JAGGI, B. Pollution disclosures, pollution performance and economic performance. Omega - International Journal of Management Science, v. 10, n. 2, p. 167-176, 1982.

FREEMAN, R. E. Strategic management - a stakeholder approach. 1st ed. Marshfield (MA): Pitman Publishing Inc., 1984. 276 p.

FRIEDMAN, M.; FRIEDMAN, R. Capitalism and freedom. 2nd ed. Chicago: The University of Chicago Press, 1962. 166 p.

FRIEDMAN, M. The social responsibility of business is to increase its profits. The New York Times Magazine, New York, September 13, 1970.

FRY, F. L.; HOCK, R. J. Who claims corporate responsibility? The biggest and the worst. Business and Society Review, v. 18, n. 1, p. 62-65, 1976.

FRY. L. W.; KEIM, G. D.; MEINERS, R. E. Corporate contributions: Altruistic or for profit? Academy of Management Journal, v. 25, n. 1, p. 94-106, 1982. 
GODFREY, P. C.; HATCH, N. W. Researching corporate social responsibility: An agenda for the 21 st century. Journal of Business Ethics, v. 70, n. 1, p. 87-98, 2007.

GOLDMAN SACHS. GS SUSTAIN: Challenges in ESG disclosure and consistency. New York: The Goldman Sachs Group, Inc., 2009. 22 p.

GONÇALVES, A. C.; ALMEIDA, R. M. V. R.; LINS, M. P. E.; SAMANEZ, C. $P$. Canonical correlation analysis in the definition of weight restrictions for data envelopment analysis. Journal of Applied Statistics, v. 40, n. 5, p. 1032-1043, 2013.

GUERARD JR, J. B. Additional evidence on the cost of being socially responsible in investing. The Journal of Investing, v.6, n. 4, p. 31-36, 1997.

GLOBAL REPORTING INITIATIVE. Reporting Principles and standard disclosures. Amsterdam: GRI, 2014. 92p.

GRIFFIN, J. J.; MAHON, J. F. The corporate social performance and corporate financial performance debate: Twenty-five years of incomparable research. Business and Society, v. 36, n. 1, p. 5-31, 1997.

GROSSMAN, B. R.; SHARPE, W. F. Financial implications of South African divestment. Financial Analysts Journal, v. 42, n. 4, p. 15-29, 1986.

GUTHRIE, J.; PARKER, L. Corporate Social Disclosure Practice: A Comparative International Analysis. Advances in Public Interest Accounting, v. 3, n. 1, p. 159-175, 1990.

HASNAS, J. The Normative Theories of Business Ethics: A Guide for the Perplexed. Business Ethics Quarterly, v. 8, n. 1, p. 19-42, 1998.

HEALD, M. Management's Responsibility to Society: The Growth of an Idea. The Business History Review, v. 31, n. 4 (Winter, 1957), p. 375-384, 1957.

HEUGENS, P.M.A.R.; KAPTEIN, M.; VAN OOSTERHOUT, J. Contracts to communities: A processual model of organizational virtue. Journal of Management Studies, v. 45, n. 1, p. 100-121, 2008.

HOLLINGSWORTH, B.; SMITH, P. Use of ratios in data envelopment analysis. Applied Economic Letters, v. 10, n. 11, p. 733-735, 2003.

HUGHES, S. B.; ANDERSEN, A.; GOLDEN, S. Corporate Environmental Disclosures: Are they useful in determining environmental performance? Journal of Accounting and Public Policy, v. 20, n. 3, p. 217-240, 2001.

INFOMONEY. Meio ambiente: $52 \%$ dos brasileiros pagariam mais por produtos $\quad$ sustentáveis. $2012 . \quad$ Available at: http://www.infomoney.com.br/minhas-financas/noticia/2426383/. Accessed May 21, 2014.

JAGANNATHAN, R.; MA, T. Risk reduction in large portfolios: Why imposing the wrong constraint helps. The Journal of Finance, v. 54, n. 4, p. 1651-1683, 2003.

JARQUE, C. M.; BERA, A. K. A test for normality of observations and regression residuals. International Statistical Review, v. 55, n. 2, p. 163-172, 1987.

JENSEN, M. C. The performance of mutual funds in the period 1945-1964. The Journal of Finance, v. 23, n. 2, p. 389-416, 1968. 
JONES, T. M. Corporate Social Responsibility revisited, redefined. California Management Review, v. 22, n. 3, p. 59-67, 1980.

JORION, P. Bayesian and CAPM estimators of the means: Implications for portfolio selection. Journal of Banking and Finance, v. 15, n. 3, p. 717-727, 1992.

KEATING, C.; SHADWICK, W. F. A universal performance measure. Journal of Performance Measurement, v. 6, n. 3, p. 59-84, 2002a.

KEATING, C.; SHADWICK, W. F. An introduction to omega. 1st ed. London: The Finance Development Centre London, 2002b. 15 p.

KING, A. A.; LENOX, M. J. Industry self-regulation without sanctions: The chemical industry's responsible care program. The Academy of Management Journal, v. 43, n. 4, p. 698-716, 2000.

KOOPMANS, T. C. Activity analysis of production and allocation. In: COWLES COMISSION MONOGRAPH No. 13 (eds.). Chapter III. New York: John Wiley \& Sons, Inc., 1951, p. 33-95.

KPMG INTERNATIONAL. KPMG International Survey of Corporate Responsibility Reporting 2011. Malvern (PA): Evalueserve, Inc, 2011, 34 p.

KWIATKOWSKI, D.; PHILLIPS, P. C. B.; SCHMIDT, P.; SHIN, Y. C. Testing the null hypothesis of stationarity against the alternative of a unit root. Journal of Econometrics, v. 54, n. 1-3, p. 159-178, 1992.

LEVITT, T. The dangers of social responsibility. Harvard Business Review, v. 36, n. 5, p. 41-50, 1958.

LIN, C-H.; YANG, H-L.; LIOU, D-Y. The impact of corporate social responsibility on financial performance: Evidence from business in Taiwan. Technology in Society, v. 31, n. 1, p. 56-63, 2009.

LINDGREEN, A.; SWAEN, V. Corporate social responsibility. International Journal of Management Reviews, v. 12, n. 1, p. 1-7, 2010.

LINTNER, J. Security prices, risk, and maximal gains from diversification. The Journal of Finance, v. 20, n. 4, p. 587-615, 1965.

LOURENÇO, I. C.; BRANCO, M. C. Determinants of corporate sustainability performance in emerging markets: the Brazilian case. Journal of Cleaner Production, v. 57, n. 1, p. 134-141, 2013.

MACEDO, M. A. S.; CORRAR, L. J.; SIQUEIRA, J. R. M. Análise comparativa do desempenho contábil-financeiro de empresas socioambientalmente responsáveis no Brasil. BASE - Revista de Administração e Contabilidade da Unisinos, v. 9, n. 1, p. 13-26, 2012.

MACEDO, M. A. S.; SOUSA, A. C.; SOUSA, A. C. C.; CÍPOLA, F. C. Desempenho de empresas socialmente responsáveis: Uma análise por índices contábil-financeiros. Revista Produção Online, v. Esp., 2007.

MACKINNON, J. G. Numerical distribution functions for unit root and cointegration tests. Journal of Applied Econometrics, v. 11, n. 6, p. 601-618, 1996.

MANNE, H. G.; WALLICH, H. C. The modern corporation and social responsibility. 1st ed. Washington, DC: American Enterprise Institute for Public Policy Research, 1973. 106 p. 
MARKOWITZ, H. Portfolio selection. The Journal of Finance, v. 7, n. 1, p. 7791,1952

MCGUIRE, J. B.; SUNDGREN, A.; SCHNEEWEIS, T. Corporate social responsibility and firm financial performance. Academy of Management Journal, v. 31, n. 4, p. 854-872, 1988.

MCGUIRE, J. W. Business and society. 1st ed. New York: McGraw-Hill, 1963. $320 \mathrm{p}$.

MEZA, L. A.; BIONDI NETO, L.; MELLO, J. C. C. B. S.; GOMES, E. G. ISYDS - Integrated System for Decision Support (SIAD - Sistema Integrado de Apoio à Decisão): a software package for data envelopment analysis model. Pesquisa Operacional [online], v. 25, n. 3, p. 493-503, 2005.

MILNE, M. J.; ADLER, R. W. Exploring the Reliability of Social and Environmental Disclosures Content Analysis. Accounting, Auditing \& Accountability Journal, v. 12, n. 2, p. 237-256, 1999.

MOSSIN, J. Equilibrium in a capital asset market. Econometrica, v. 34, n. 4, p. 768-783, 1966.

MULLER, A.; KOLK, A. Extrinsic and intrinsic drivers of corporate social performance: evidence from foreign and domestic firms in Mexico. Journal of Management Studies, v. 47, n. 1, p. 1-26, 2010.

MUNIAPAN, B.; DASS, M. Corporate Social Responsibility: a philosophical approach from an ancient Indian perspective. International Journal of Indian Culture and Business Management, v. 1, n. 4, p. 408-420, 2008.

NEU, D.; WARSAME, H.; PEDWELL, K. Managing public impressions: Environmental disclosures in annual reports. Accounting, Organizations and Society, v. 23, n. 3, p. 265-282, 1998.

ORTAS, E.; MONEVA, J. M.; SALVADOR, M. Does socially responsible investment equity indexes in emerging markets pay off? Evidence from Brazil. Emerging Markets Review, v. 13, n. 4, p. 581-597, 2012.

PALAZZO, G.; SCHERER, A. G. Corporate legitimacy as deliberation: a communicative framework. Journal of Business Ethics, v. 66, n. 1, p. 71-88, 2006.

PRESTON, L. E.; POST, J. E. Private management and public policy: The principle of public responsibility. 1st ed. Englewood Cliffs, NJ: Prentice Hall, 1975.

PRINCIPLES FOR RESPONSIBLE INVESTMENTS. Available at: <http://www.unpri.org/>. Accessed May 20, 2014.

RENNEBOOG, L.; TERHORST, J.; ZHANG, C. Socially responsible investments: Institutional aspects, performance, and investor behavior. Journal of Banking and Finance, v. 32, n. 9, p. 1723-1742, 2008.

ROBERTS, R. W. Determinants of corporate social responsibility disclosure: An application of stakeholder theory. Accounting, Organizations and Society, v. 17, n. 6, p. 595-612, 1992.

RUDD, A. Social responsibility and portfolio performance. California Management Review, v. 23, n. 4, p. 55-61, 1981. 
SAID, S. E.; DICKEY, D. A. Testing for unit roots in autoregressive-moving average model of unknown order. Biometrika, v. 71, n. 3, p. 599-607, 1984.

SAMANEZ, C. P. Gestão de investimentos e geração de valor. 1st ed. São Paulo: Pearson Prentice Hall, 2007. 400 p.

SCHARF, R. Why Brazil Leads the Region in CSR. Americas Quartely, North Hollywood (CA), v. 2, n. 3 (Winter 2008), p. 288-289, 2008.

SCHWARZ, G. Estimating the dimension of a model. The Annals of Statistics, v. 6, n. 2, p. 461-464, 1978.

SCOTT, R. C.; HORVATH, P. A. On the direction of preference for moments of higher order than the variance. The Journal of Finance, v. 35, n. 4 , p. 915-919, 1980.

SELEKMAN, B. A moral philosophy for business. 1st ed. New York: McGrawHill, 1959.

SETHI, S. P. Dimensions of corporate social performance: An analytic framework. California Management Review, v. 17, n. 3, p. 58-64, 1975.

SHARPE, W. F. Capital asset prices: a theory of market equilibrium under conditions of risk. The Journal of Finance, v. 19, n. 3, p. 425-442, 1964.

SHARPE, W. F. Mutual fund performance. The Journal of Business, v. 39, n. 1, p. 119-138, 1966.

SKILLIUS, A.; WENNBERG, U. Continuity, credibility and comparability: Key challenges for corporate environmental performance measurement and communication. In: __ Invitational Expert Seminar 1998. 3rd ed. Èze, France: IIIEE Communications, 1998, p. 95-162.

SORTINO, F. A.; PRICE, L. N. Performance measurement in a downside risk framework. The Journal of Investing, v. 3, n. 3, p. 59-64, 1994.

SPENCER, B. A.; TAYLOR, G. S. A within and between analysis of the relationship between corporate social responsibility and financial performance. Akron Business and Economic Review, v. 18, n. 3, p. 7-18, 1987.

STRACHAN, J. L.; SMITH, D. B.; BEEDLES, W. L. The price reaction to (alleged) corporate crime. The Financial Review, v. 18, n. 2, p. 121-132, 1983.

THE EQUATOR PRINCIPLES site. Available at: <http://www.equatorprinciples.com>. Accessed May 20, 2014.

TILT, C. A. The content and disclosure of Australian corporate environmental policies. Accounting, Auditing \& Accountability Journal, v. 14, n. 2, p. 90-212, 2000.

TREYNOR, J. L. How to rate management of investment funds. Harvard Business Review, v. 43, n. 1, p. 63-75, 1965.

TSANG, E. W. K. A longitudinal study of corporate social reporting in Singapore: The case of the banking, food and beverages and hotel industries. Accounting, Auditing \& Accountability, v. 11, n. 5, p. 624-635, 1998.

UNITED NATIONS ENVIRONMENT PROGRAMME FINANCE INITIATIVE (UNEP FI). The Materiality of Social, Environmental and Corporate Governance Issues to Equity Pricing. Genève: UNEP FI, 2004. 54 p. 
UNITED NATIONS ENVIRONMENT PROGRAMME FINANCE INITIATIVE (UNEP FI). Principles for Responsible Investment: Annual Report 2014. Genève: UNEP FI, 2014. 53 p.

UNITED NATIONS INDUSTRIAL DEVELOPMENT ORGANIZATION (UNIDO). What is CSR? 2013. Available at: http://www.unido.org/en/what-wedo/trade/csr/what-is-csr.html. Accessed May 23, 2014.

VIVES, A.; WADHWA, B. Sustainability indices in emerging markets: Impact on responsible practices and financial market development. Journal of Sustainable Finance \& Investment, v. 2, n. 3-4, p. 318-337, 2012.

WALTON, C. C. Corporate social responsibilities. 1st ed. Belmont: Wadsworth Publishing Company, 1967. 177 p.

WOKUTCH, R. E.; SPENCER, B. A. Corporate saints and sinners: The effects of philanthropic and illegal activity on organizational performance. California Management Review, v. 29, n. 2, p. 62-77, 1987.

WORLD BUSINESS COUNCIL FOR SUSTAINABLE DEVELOPMENT. Translating ESG into sustainable business value: Key insights for companies and investors. Genève: WBCSD, 2010. 33 p.

YAMASHITA, M.; SEN, S.; ROBERTS, M. C. The rewards for environmental conscientiousness in the U.S. capital markets. Journal of Financial and Strategic Decisions, v. 12, n. 1, p. 73-82, 1999.

YOUNG, R. Dilemmas and advances in corporate social responsibility in Brazil: The work of the Ethos Institute. Natural Resources Forum, v. 28, n. 4, p. 291301, 2004. 


\section{Appendix A - Assets included in portfolio formation}

Observations:

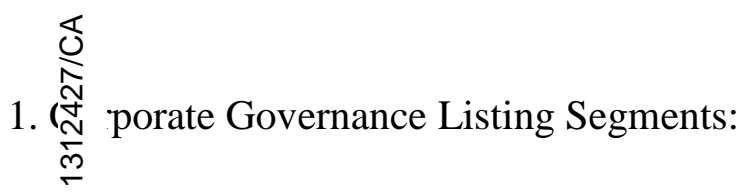

(Nlz Novo Mercado

(N Nivel 1 of Corporate Governance

(No: Vível 2 of Corporate Governance

(Mid Bovespa Mais

造

Fo 㴆

$h t t l_{1}^{\mathrm{O}}$ ' $w$ ww.bmfbovespa.com.br/en-us/markets/equities/companies/corporate-governance.aspx

을

2. ํํํ ck Classes:
(M2) Bovespa Mais Nível 2

(MB) Traditional Org. OTC (over-the-counter)

(DR1) Level 1 BDR (Brazilian Depositary

Receipts)
(DR2) Level 2 BDR

(DR3) Level 3 BDR

(DRN) Unsponsored BDRs

A company can choose to issue different classes of stocks to certain investors, board members or company founders. In brief terms, two main classes of assets prevail: common and preferred shares. In Brazil, these stocks usually receive the number 3 and 4, respectively, at the end of their tickers. Holders of common stock exercise control by electing a board of directors and voting on corporate policy. Common stockholders are on the bottom of the priority ladder for ownership structure. In the event of liquidation, common shareholders have rights to a company's assets only after bondholders, preferred shareholders and other debtholders have been paid in full. Preferred stocks, in turn, constitute a class of ownership in a corporation that has a higher claim on the assets and earnings than common stock. In addition, they generally have dividends that must be paid out before dividends to common stockholders and the shares usually do not have voting rights. This last assumption holds for Brazil.

In addition to the above, companies that choose to have multiple classes of common stock issue up to four other classes, usually denoted as Class $\mathrm{A}$ (number 5 at the end of the ticker), Class B (number 6 at the end of the ticker), Class C (7) and Class D (8) shares. A common practice is to assign more dividends to one class of stock than the other, however, the classification depends on the statute of each company.

Units, in turn, are assets composed by more than one class of securities, such as a common stock and a subscription warrant, for example, traded together. In Brazil, units are identified by the number 11 at the end of their tickers.

Some tickers also receive the B letter at the end, which indicates that the asset is traded at the Brazilian traditional over-the-counter (OTC) market. Unlike exchanges, OTC markets have never been a "place". They are less formal, although often well-organized, networks of trading relationships centered around one or more dealers.

For further details on the BM\&FBOVESPA methodology, the interested reader is referred to:

http://www.mundotrade.com.br/codigo-acoes-bovespa 
Appendix A - Assets included in the portfolio formation

\begin{tabular}{|c|c|c|c|c|c|c|}
\hline s & Company & $\begin{array}{l}\text { Corporate } \\
\text { Governance }\end{array}$ & Ticker & Stock Class & $\begin{array}{l}\text { Trade Name } \\
\text { Indication }\end{array}$ & Observations \\
\hline $\bar{m}$ & AES ELPA S.A. & - & AELP3 & Common Share & $\mathrm{ON}$ & - \\
\hline : & AES TIETE S.A. & - & GETI3 & Common Share & $\mathrm{ON}$ & - \\
\hline 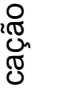 & AES TIETE S.A. & - & GETI4 & Preferred Share & PN & - \\
\hline 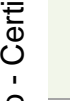 & $\begin{array}{l}\text { AFLUENTE GERAÇÃO DE ENERGIA } \\
\text { ELÉTRICA S.A. }\end{array}$ & - & AFLU3 & Common Share & ON & - \\
\hline ט. & $\begin{array}{c}\text { AFLUENTE TRANSMISSÃO DE ENERGIA } \\
\text { ELÉTRICA S/A }\end{array}$ & - & AFLT3 & Common Share & $\mathrm{ON}$ & \\
\hline 6 & AMPLA ENERGIA E SERVICOS S.A. & - & CBEE3 & Common Share & $\mathrm{ON}$ & - \\
\hline 7 & $\begin{array}{l}\text { CENTRAIS ELET BRAS S.A. - } \\
\text { ELETROBRAS }\end{array}$ & N1 & ELET3 & Common Share & $\mathrm{ON}$ & - \\
\hline 8 & $\begin{array}{l}\text { CENTRAIS ELET BRAS S.A. - } \\
\text { ELETROBRAS }\end{array}$ & N1 & ELET6 & Preferred Share Class B & PNB & - \\
\hline 9 & $\begin{array}{c}\text { CENTRAIS ELET DE SANTA CATARINA } \\
\text { S.A. }\end{array}$ & N2 & CLSC3 & Common Share & $\mathrm{ON}$ & - \\
\hline 10 & CENTRAIS ELET DO PARA S.A. - CELPA & - & CELP3 & Common Share & $\mathrm{ON}$ & Delisted in April 7, 2011 \\
\hline 11 & CENTRAIS ELET DO PARA S.A. - CELPA & - & CELP5 & Preferred Share Class A & PNA & Low Liquidity \\
\hline 12 & $\begin{array}{c}\text { CENTRAIS ELET MATOGROSSENSES } \\
\text { S.A.- CEMAT }\end{array}$ & - & CMGR3 & Common Share & $\mathrm{ON}$ & - \\
\hline 13 & $\begin{array}{c}\text { CENTRAIS ELET MATOGROSSENSES } \\
\text { S.A.- CEMAT }\end{array}$ & - & CMGR4 & Preferred Share & $\mathrm{PN}$ & Low Liquidity \\
\hline
\end{tabular}


Appendix A - Assets included in the portfolio formation (Continued)

\begin{tabular}{|c|c|c|c|c|c|c|}
\hline 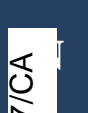 & Company & $\begin{array}{l}\text { Corporate } \\
\text { Governance }\end{array}$ & Ticker & Stock Class & $\begin{array}{l}\text { Trade Name } \\
\text { Indication }\end{array}$ & Observations \\
\hline$\frac{m_{0}}{a} 1$ & CESP - CIA ENERGETICA DE SAO PAULO & N1 & CESP3 & Common Share & $\mathrm{ON}$ & - \\
\hline$\frac{2}{\frac{\pi}{0}}$ & CESP - CIA ENERGETICA DE SAO PAULO & N1 & CESP5 & $\begin{array}{l}\text { Preferred Share } \\
\text { Class A }\end{array}$ & PNA & - \\
\hline 胥, & CESP - CIA ENERGETICA DE SAO PAULO & N1 & CESP6 & $\begin{array}{l}\text { Preferred Share } \\
\text { Class B }\end{array}$ & PNB & - \\
\hline $\begin{array}{ccc}\frac{4}{ \pm} \\
\\
0 \\
1\end{array}$ & $\begin{array}{l}\text { CIA ELETRICIDADE EST. DA BAHIA - } \\
\text { COELBA }\end{array}$ & - & CEEB3 & Common Share & $\mathrm{ON}$ & - \\
\hline 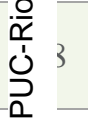 & CIA ENERGETICA DE BRASILIA & - & CEBR3 & Common Share & $\mathrm{ON}$ & - \\
\hline 19 & $\begin{array}{l}\text { CIA ENERGETICA DE MINAS GERAIS - } \\
\text { CEMIG }\end{array}$ & N1 & CMIG3 & Common Share & ON & - \\
\hline 20 & $\begin{array}{l}\text { CIA ENERGETICA DE MINAS GERAIS - } \\
\text { CEMIG }\end{array}$ & N1 & CMIG4 & Preferred Share & $\mathrm{PN}$ & - \\
\hline 21 & $\begin{array}{c}\text { CIA ENERGETICA DE PERNAMBUCO - } \\
\text { CELPE }\end{array}$ & - & CEPE5 & $\begin{array}{l}\text { Preferred Share } \\
\text { Class A }\end{array}$ & PNA & - \\
\hline 22 & CIA ENERGETICA DO CEARA - COELCE & - & COCE3 & Common Share & $\mathrm{ON}$ & - \\
\hline 23 & CIA ENERGETICA DO CEARA - COELCE & - & COCE5 & $\begin{array}{l}\text { Preferred Share } \\
\text { Class A }\end{array}$ & PNA & - \\
\hline 24 & $\begin{array}{l}\text { CIA ENERGETICA DO MARANHAO - } \\
\text { CEMAR }\end{array}$ & MB & ENMA3B & Common Share & $\mathrm{ON}$ & Available only after August 30, 2010 \\
\hline 25 & $\begin{array}{l}\text { CIA ENERGETICA DO RIO GDE NORTE - } \\
\text { COSERN }\end{array}$ & - & CSRN3 & Common Share & $\mathrm{ON}$ & - \\
\hline 26 & $\begin{array}{l}\text { CIA ESTADUAL DE DISTRIB ENER ELET- } \\
\text { CEEE-D }\end{array}$ & N1 & CEED3 & Common Share & $\mathrm{ON}$ & - \\
\hline
\end{tabular}


Appendix A - Assets included in the portfolio formation (Continued)

\begin{tabular}{|c|c|c|c|c|c|c|}
\hline & Company & $\begin{array}{l}\text { Corporate } \\
\text { Governance }\end{array}$ & Ticker & Stock Class & $\begin{array}{l}\text { Trade Name } \\
\text { Indication }\end{array}$ & Observations \\
\hline$\frac{\substack{d \\
\frac{1}{m}}}{0} 7$ & $\begin{array}{l}\text { CIA ESTADUAL GER.TRANS.ENER.ELET- } \\
\text { CEEE-GT }\end{array}$ & N1 & EEEL3 & Common Share & $\mathrm{ON}$ & - \\
\hline$\frac{\bar{\pi}}{\overline{\frac{\pi}{5}}} 3$ & $\begin{array}{l}\text { CIA ESTADUAL GER.TRANS.ENER.ELET- } \\
\text { CEEE-GT }\end{array}$ & N1 & EEEL4 & Preferred Share & PN & - \\
\hline 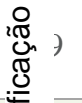 & CIA PARANAENSE DE ENERGIA - COPEL & N1 & CPLE3 & Common Share & $\mathrm{ON}$ & - \\
\hline 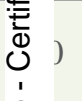 & CIA PARANAENSE DE ENERGIA - COPEL & N1 & CPLE6 & $\begin{array}{l}\text { Preferred Share } \\
\text { Class B }\end{array}$ & PNB & - \\
\hline 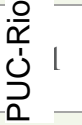 & CPFL ENERGIA S.A. & NM & CPFE3 & Common Share & $\mathrm{ON}$ & - \\
\hline 32 & $\begin{array}{c}\text { CTEEP - CIA TRANSMISSÃO ENERGIA } \\
\text { ELÉTRICA PAULISTA }\end{array}$ & N1 & TRPL4 & Preferred Share & PN & - \\
\hline 33 & $\begin{array}{l}\text { DUKE ENERGY INT. GER. } \\
\text { PARANAPANEMA S.A. }\end{array}$ & - & GEPA3 & Common Share & ON & - \\
\hline 34 & $\begin{array}{l}\text { DUKE ENERGY INT. GER. } \\
\text { PARANAPANEMA S.A. }\end{array}$ & - & GEPA4 & Preferred Share & PN & - \\
\hline 35 & EDP - ENERGIAS DO BRASIL S.A. & NM & ENBR3 & Common Share & $\mathrm{ON}$ & - \\
\hline 36 & $\begin{array}{c}\text { ELEKTRO - ELETRICIDADE E SERVICOS } \\
\text { S.A. }\end{array}$ & - & EKTR4 & Preferred Share & PN & - \\
\hline 37 & $\begin{array}{c}\text { ELETROBRÁS PARTICIPAÇÕES S.A. - } \\
\text { ELETROPAR }\end{array}$ & - & LIPR3 & Common Share & $\mathrm{ON}$ & - \\
\hline 38 & $\begin{array}{l}\text { ELETROPAULO METROP. ELET. SAO } \\
\text { PAULO S.A. }\end{array}$ & N2 & ELPL3 & Common Share & ON & - \\
\hline 39 & $\begin{array}{l}\text { ELETROPAULO METROP. ELET. SAO } \\
\text { PAULO S.A. }\end{array}$ & N2 & ELPL4 & Preferred Share & PN & - \\
\hline
\end{tabular}


Appendix A - Assets included in the portfolio formation (Continued)

\begin{tabular}{|c|c|c|c|c|c|c|}
\hline 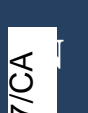 & Company & $\begin{array}{l}\text { Corporate } \\
\text { Governance }\end{array}$ & Ticker & Stock Class & $\begin{array}{l}\text { Trade Name } \\
\text { Indication }\end{array}$ & Observations \\
\hline$\frac{N}{\frac{N}{m}}$ & $\begin{array}{l}\text { EMAE - EMPRESA METROP.AGUAS } \\
\text { ENERGIA S.A. }\end{array}$ & - & EMAE4 & Preferred Share & PN & - \\
\hline 产 & ENERGISA S.A. & - & ENGI3 & Common Share & $\mathrm{ON}$ & - \\
\hline 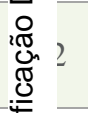 & ENERGISA S.A. & - & ENGI4 & Preferred Share & PN & - \\
\hline $\begin{array}{l}\frac{ \pm}{ \pm} \\
0 \\
0\end{array}$ & ENEVA S.A & NM & ENEV3 & Common Share & $\mathrm{ON}$ & - \\
\hline 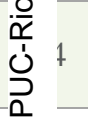 & EQUATORIAL ENERGIA S.A. & NM & EQTL3 & Common Share & $\mathrm{ON}$ & - \\
\hline 45 & GTD PARTICIPACOES S.A. & MB & GTDP3B & Common Share & ON & Available only after August 26, 2010 \\
\hline 46 & GTD PARTICIPACOES S.A. & MB & GTDP4B & Preferred Share & PN & Available only after August 26, 2010 \\
\hline 47 & LIGHT S.A. & NM & LIGT3 & Common Share & $\mathrm{ON}$ & - \\
\hline 48 & REDE ENERGIA S.A. & - & REDE3 & Common Share & $\mathrm{ON}$ & - \\
\hline 49 & REDE ENERGIA S.A. & - & REDE4 & Preferred Share & PN & - \\
\hline 50 & REDENTOR ENERGIA S.A. & - & RDTR3 & Common Share & ON & Available only after September 27, 2011 \\
\hline 51 & TRACTEBEL ENERGIA S.A. & NM & TBLE3 & Common Share & ON & - \\
\hline
\end{tabular}




\section{Appendix B - Assets excluded from the analysis}

Observations:

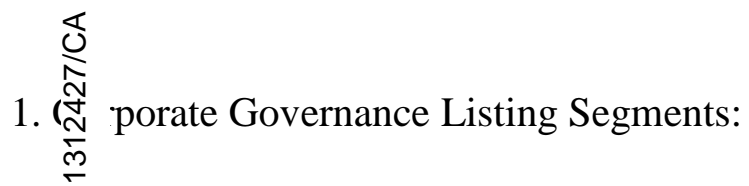

(Nlo Novo Mercado

(N Nivel 1 of Corporate Governance

(No vível 2 of Corporate Governance

(Mid Bovespa Mais

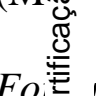

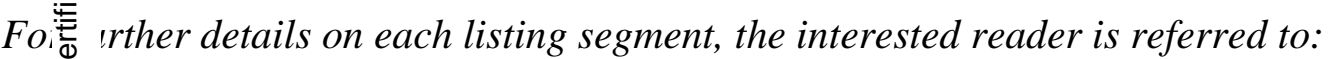

$h t t l_{1}^{\mathrm{O}}$ ' $w$ ww.bmfbovespa.com.br/en-us/markets/equities/companies/corporate-governance.aspx

$\stackrel{\circ}{\pi}$

2. 约 ck Classes:

A company can choose to issue different classes of stocks to certain investors, board members or company founders. In brief terms, two main classes of assets prevail: common and preferred shares. In Brazil, these stocks usually receive the number 3 and 4, respectively, at the end of their tickers. Holders of common stock exercise control by electing a board of directors and voting on corporate policy. Common stockholders are on the bottom of the priority ladder for ownership structure. In the event of liquidation, common shareholders have rights to a company's assets only after bondholders, preferred shareholders and other debtholders have been paid in full. Preferred stocks, in turn, constitute a class of ownership in a corporation that has a higher claim on the assets and earnings than common stock. In addition, they generally have dividends that must be paid out before dividends to common stockholders and the shares usually do not have voting rights. This last assumption holds for Brazil.

In addition to the above, companies that choose to have multiple classes of common stock issue up to four other classes, usually denoted as Class $\mathrm{A}$ (number 5 at the end of the ticker), Class B (number 6 at the end of the ticker), Class C (7) and Class D (8) shares. A common practice is to assign more dividends to one class of stock than the other, however, the classification depends on the statute of each company.

Units, in turn, are assets composed by more than one class of securities, such as a common stock and a subscription warrant, for example, traded together. In Brazil, units are identified by the number 11 at the end of their tickers.

Some tickers also receive the B letter at the end, which indicates that the asset is traded at the Brazilian traditional over-the-counter (OTC) market. Unlike exchanges, OTC markets have never been a "place". They are less formal, although often well-organized, networks of trading relationships centered around one or more dealers.

For further details on the BM\&FBOVESPA methodology, the interested reader is referred to:

http://www.mundotrade.com.br/codigo-acoes-bovespa 
Appendix B - Assets excluded from the analysis

\begin{tabular}{|c|c|c|c|c|c|c|}
\hline & Company & $\begin{array}{l}\text { Corporate } \\
\text { Governance }\end{array}$ & Ticker & Stock Class & $\begin{array}{l}\text { Trade Name } \\
\text { Indication }\end{array}$ & Reason for exclusion \\
\hline 5 & 521 PARTICIPACOES S.A. & $\mathrm{MB}$ & - & - & - & No assets traded in Cash Market \\
\hline : & 524 PARTICIPACOES S.A. & MB & QVQP3B & - & - & No assets traded in Cash Market \\
\hline 胥 & $\begin{array}{l}\text { AES SUL DISTRIB GAUCHA DE ENERGIA } \\
\text { S.A. }\end{array}$ & & - & - & - & No assets traded in Cash Market \\
\hline E & $\begin{array}{l}\text { AFLUENTE GERAÇÃO DE ENERGIA } \\
\text { ELÉTRICA S.A. }\end{array}$ & & AFLU5 & $\begin{array}{l}\text { Preferred Share } \\
\text { Class A }\end{array}$ & PNA & $\begin{array}{c}\text { Low Liquidity; Delisted (not traded since } \\
\text { January 10, 2012) }\end{array}$ \\
\hline 荇 & $\begin{array}{l}\text { AFLUENTE GERAÇÃO DE ENERGIA } \\
\text { ELÉTRICA S.A. }\end{array}$ & & AFLU6 & $\begin{array}{l}\text { Preferred Share } \\
\text { Class B }\end{array}$ & PNB & Delisted \\
\hline 6 & ALUPAR INVESTIMENTO S/A & $\mathrm{N} 2$ & ALUP3 & Common Share & $\mathrm{ON}$ & $\begin{array}{l}\text { Unavailable; Traded only in Units } \\
\text { (ALUP11 = } 1 \text { common stock }+2 \\
\text { preferred stocks) }\end{array}$ \\
\hline 7 & ALUPAR INVESTIMENTO S/A & $\mathrm{N} 2$ & ALUP4 & Preferred Share & $\mathrm{PN}$ & Traded only in Units \\
\hline 8 & ALUPAR INVESTIMENTO S/A & $\mathrm{N} 2$ & ALUP11 & Unit & UNT & Traded only in Units \\
\hline 9 & $\begin{array}{c}\text { ANDRADE GUTIERREZ CONCESSOES } \\
\text { S.A. }\end{array}$ & MB & ANDG3B & Common Share & $\mathrm{ON}$ & Security not traded. \\
\hline 10 & $\begin{array}{c}\text { ANDRADE GUTIERREZ CONCESSOES } \\
\text { S.A. }\end{array}$ & $\mathrm{MB}$ & ANDG4B & Common Share & $\mathrm{ON}$ & Security not traded. \\
\hline 11 & $\begin{array}{c}\text { BAESA - ENERGETICA BARRA GRANDE } \\
\text { S.A. }\end{array}$ & & - & - & - & No assets traded in Cash Market \\
\hline 12 & BANDEIRANTE ENERGIA S.A. & & - & - & - & No assets traded in Cash Market \\
\hline 13 & BONAIRE PARTICIPACOES S.A. & MB & BNPA3B & Common Share & $\mathrm{ON}$ & Security not traded. \\
\hline
\end{tabular}


Appendix B - Assets excluded from the analysis (Continued)

\begin{tabular}{|c|c|c|c|c|c|c|}
\hline 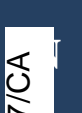 & Company & $\begin{array}{l}\text { Corporate } \\
\text { Governance }\end{array}$ & Ticker & Stock Class & $\begin{array}{l}\text { Trade Name } \\
\text { Indication }\end{array}$ & Reason for exclusion \\
\hline$\frac{N}{\frac{N}{m}}$ & $\begin{array}{l}\text { CACHOEIRA PAULISTA TRANSMISSORA } \\
\text { ENERGIA S.A. }\end{array}$ & MB & - & - & - & No assets traded in Cash Market \\
\hline 产 & CEMIG DISTRIBUICAO S.A. & & - & - & - & No assets traded in Cash Market \\
\hline 芷 & CEMIG GERACAO E TRANSMISSAO S.A. & & - & - & - & No assets traded in Cash Market \\
\hline $\begin{array}{l}\frac{5}{ \pm} \\
0 \\
0\end{array}$ & $\begin{array}{l}\text { CENTRAIS ELET BRAS S.A. - } \\
\text { ELETROBRAS }\end{array}$ & N1 & ELET5 & $\begin{array}{l}\text { Preferred Share } \\
\text { Class A }\end{array}$ & PNA & Low Liquidity \\
\hline 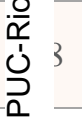 & $\begin{array}{l}\text { CENTRAIS ELET DE SANTA CATARINA } \\
\text { S.A. }\end{array}$ & N2 & CLSC4 & Preferred Share & $\mathrm{PN}$ & Low Liquidity \\
\hline 19 & $\begin{array}{l}\text { CENTRAIS ELET DE SANTA CATARINA } \\
\text { S.A. }\end{array}$ & $\mathrm{N} 2$ & CLSC5 & $\begin{array}{l}\text { Preferred Share } \\
\text { Class A }\end{array}$ & PNA & $\begin{array}{c}\text { Low Liquidity; Delisted (not traded since } \\
\text { December 25, 2011) }\end{array}$ \\
\hline 20 & $\begin{array}{l}\text { CENTRAIS ELET DE SANTA CATARINA } \\
\text { S.A. }\end{array}$ & $\mathrm{N} 2$ & CLSC6 & $\begin{array}{l}\text { Preferred Share } \\
\text { Class B }\end{array}$ & PNB & Delisted \\
\hline 21 & CENTRAIS ELET DO PARA S.A. - CELPA & & CELP6 & $\begin{array}{l}\text { Preferred Share } \\
\text { Class B }\end{array}$ & PNB & Low Liquidity \\
\hline 22 & CENTRAIS ELET DO PARA S.A. - CELPA & & CELP7 & $\begin{array}{l}\text { Preferred Share } \\
\text { Class C }\end{array}$ & PNC & Delisted \\
\hline 23 & CIA BRASILIANA DE ENERGIA & & - & - & - & No assets traded in Cash Market \\
\hline 24 & $\begin{array}{l}\text { CIA CELG DE PARTICIPACOES - } \\
\text { CELGPAR }\end{array}$ & & GPAR3 & Common Share & ON & Unavailable \\
\hline 25 & $\begin{array}{l}\text { CIA ELETRICIDADE EST. DA BAHIA - } \\
\text { COELBA }\end{array}$ & & CEEB5 & $\begin{array}{l}\text { Preferred Share } \\
\text { Class A }\end{array}$ & PNA & Low Liquidity \\
\hline 26 & $\begin{array}{l}\text { CIA ELETRICIDADE EST. DA BAHIA - } \\
\text { COELBA }\end{array}$ & & CEEB6 & $\begin{array}{l}\text { Preferred Share } \\
\text { Class B }\end{array}$ & PNB & Delisted \\
\hline
\end{tabular}


Appendix B - Assets excluded from the analysis (Continued)

\begin{tabular}{|c|c|c|c|c|c|c|}
\hline 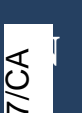 & Company & $\begin{array}{l}\text { Corporate } \\
\text { Governance }\end{array}$ & Ticker & Stock Class & $\begin{array}{l}\text { Trade Name } \\
\text { Indication }\end{array}$ & Reason for exclusion \\
\hline$\frac{N}{\frac{N}{m}} 7$ & CIA ENERGETICA DE BRASILIA & & CEBR5 & $\begin{array}{l}\text { Preferred Share } \\
\text { Class A }\end{array}$ & PNA & Low Liquidity \\
\hline$\frac{2}{\frac{\pi}{\pi}}$ & CIA ENERGETICA DE BRASILIA & & CEBR6 & $\begin{array}{l}\text { Preferred Share } \\
\text { Class B }\end{array}$ & PNB & Low Liquidity \\
\hline 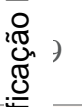 & $\begin{array}{l}\text { CIA ENERGETICA DE PERNAMBUCO - } \\
\text { CELPE }\end{array}$ & & CEPE3 & Common Share & $\mathrm{ON}$ & Low Liquidity \\
\hline 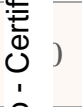 & $\begin{array}{l}\text { CIA ENERGETICA DE PERNAMBUCO - } \\
\text { CELPE }\end{array}$ & & CEPE6 & $\begin{array}{l}\text { Preferred Share } \\
\text { Class B }\end{array}$ & PNB & Low Liquidity \\
\hline 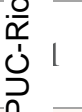 & CIA ENERGETICA DO CEARA - COELCE & & COCE6 & $\begin{array}{l}\text { Preferred Share } \\
\text { Class B }\end{array}$ & PNB & $\begin{array}{l}\text { Low Liquidity; Delisted (not traded since } \\
\text { March 20, 2012) }\end{array}$ \\
\hline 32 & $\begin{array}{c}\text { CIA ENERGETICA DO MARANHAO - } \\
\text { CEMAR }\end{array}$ & MB & ENMA5B & $\begin{array}{l}\text { Preferred Share } \\
\text { Class A }\end{array}$ & PNA & Unavailable \\
\hline 33 & $\begin{array}{l}\text { CIA ENERGETICA DO MARANHAO - } \\
\text { CEMAR }\end{array}$ & MB & ENMA6B & $\begin{array}{l}\text { Preferred Share } \\
\text { Class B }\end{array}$ & PNB & Unavailable \\
\hline 34 & $\begin{array}{l}\text { CIA ENERGETICA DO RIO GDE NORTE - } \\
\text { COSERN }\end{array}$ & & CSRN5 & $\begin{array}{l}\text { Preferred Share } \\
\text { Class A }\end{array}$ & PNA & Low Liquidity \\
\hline 35 & $\begin{array}{l}\text { CIA ENERGETICA DO RIO GDE NORTE - } \\
\text { COSERN }\end{array}$ & & CSRN6 & $\begin{array}{l}\text { Preferred Share } \\
\text { Class B }\end{array}$ & PNB & Low Liquidity \\
\hline 36 & $\begin{array}{l}\text { CIA ESTADUAL DE DISTRIB ENER ELET- } \\
\text { CEEE-D }\end{array}$ & N1 & CEED4 & Preferred Share & PN & Low Liquidity \\
\hline 37 & CIA PARANAENSE DE ENERGIA - COPEL & N1 & CPLE5 & $\begin{array}{l}\text { Preferred Share } \\
\text { Class A }\end{array}$ & PNA & Low Liquidity \\
\hline 38 & CIA PAULISTA DE FORCA E LUZ & & - & - & - & No assets traded in Cash Market \\
\hline 39 & CIA PIRATININGA DE FORCA E LUZ & & - & - & - & No assets traded in Cash Market \\
\hline
\end{tabular}


Appendix B - Assets excluded from the analysis (Continued)

\begin{tabular}{|c|c|c|c|c|c|c|}
\hline$\sigma^{\pi}$ & Company & $\begin{array}{l}\text { Corporate } \\
\text { Governance }\end{array}$ & Ticker & Stock Class & $\begin{array}{l}\text { Trade Name } \\
\text { Indication }\end{array}$ & Reason for exclusion \\
\hline$\left.\frac{m_{0}}{2}\right)$ & CPFL ENERGIAS RENOVÁVEIS S.A. & NM & CPRE3 & Common Share & $\mathrm{ON}$ & Available only after July 19, 2013 \\
\hline 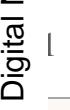 & CPFL GERACAO DE ENERGIA S.A. & & - & - & - & No assets traded in Cash Market \\
\hline 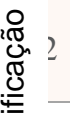 & $\begin{array}{l}\text { CTEEP - CIA TRANSMISSÃO ENERGIA } \\
\text { ELÉTRICA PAULISTA }\end{array}$ & N1 & TRPL3 & Common Share & $\mathrm{ON}$ & Low Liquidity \\
\hline 焉 & DESENVIX ENERGIAS RENOVÁVEIS S.A. & MA & DVIX3 & Common Share & $\mathrm{ON}$ & Unavailable \\
\hline 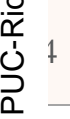 & $\begin{array}{l}\text { ELEKTRO - ELETRICIDADE E SERVICOS } \\
\text { S.A. }\end{array}$ & & EKTR3 & Common Share & $\mathrm{ON}$ & Low Liquidity \\
\hline 45 & $\begin{array}{l}\text { EMAE - EMPRESA METROP.AGUAS } \\
\text { ENERGIA S.A. }\end{array}$ & & EMAE3 & Common Share & ON & Unavailable \\
\hline 46 & $\begin{array}{c}\text { EMPRESA ENERG MATO GROS.SUL S.A.- } \\
\text { ENERSUL }\end{array}$ & & - & - & - & No assets traded in Cash Market \\
\hline 47 & ENERGISA S.A. & & ENGI11 & Unit & UNT & $\begin{array}{c}\text { Traded in common and preferred stocks } \\
\text { already }\end{array}$ \\
\hline 48 & $\begin{array}{l}\text { ESPIRITO SANTO CENTR.ELETR. S.A.- } \\
\text { ESCELSA }\end{array}$ & & - & - & - & No assets traded in Cash Market \\
\hline 49 & FORPART S.A. & MB & - & - & - & No assets traded in Cash Market \\
\hline 50 & INVESTCO S.A. & & - & - & - & No assets traded in Cash Market \\
\hline 51 & ITAPEBI GERACAO DE ENERGIA S.A. & & - & - & - & No assets traded in Cash Market \\
\hline 52 & LIGHT SERVICOS DE ELETRICIDADE S.A. & & - & - & - & No assets traded in Cash Market \\
\hline
\end{tabular}


Appendix B - Assets excluded from the analysis (Continued)

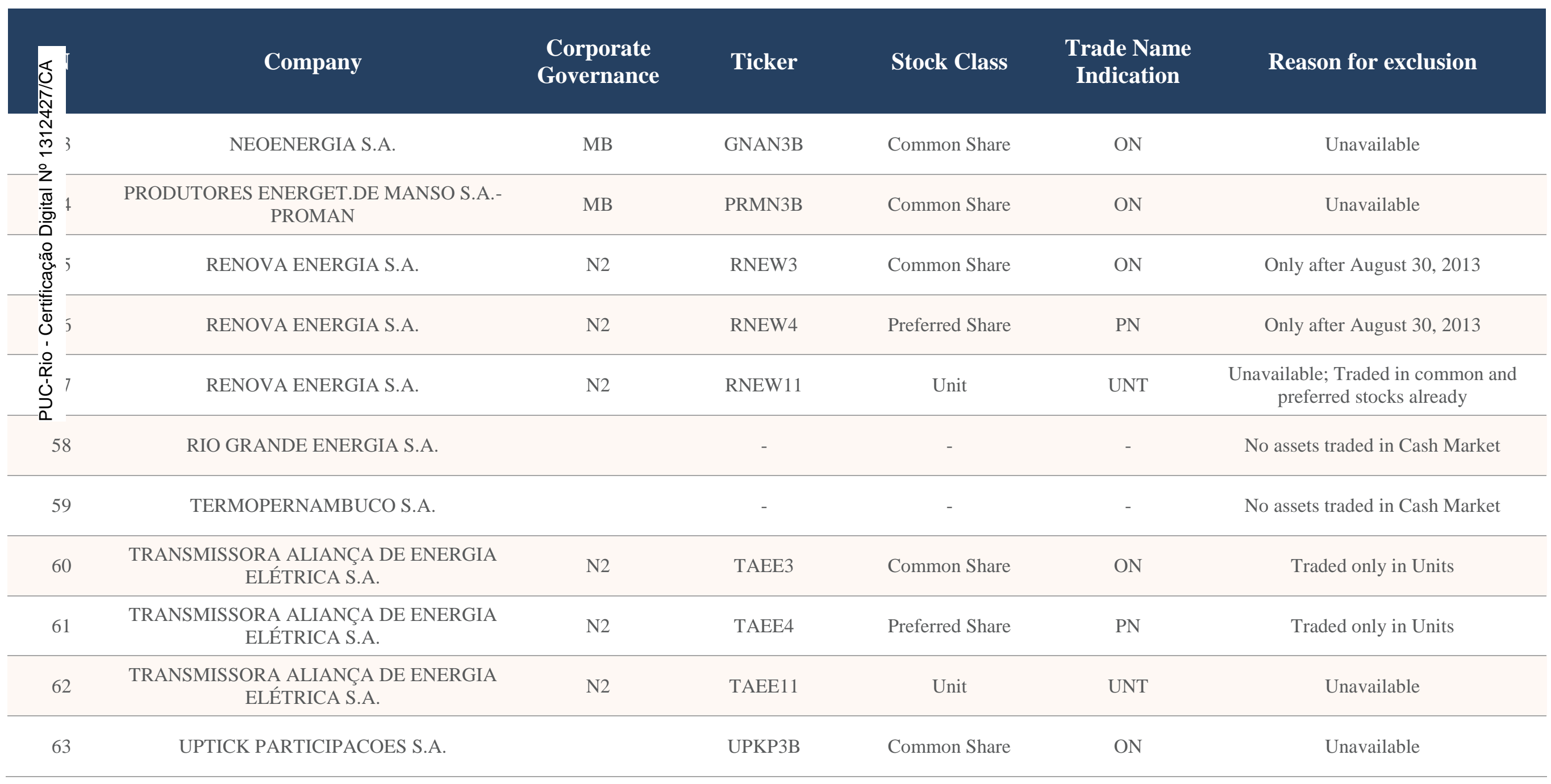




\section{Appendix C - Data Envelopment Analysis - Data for inputs and outputs}

Observations:

CSS denotes the common stock symbol of the company.

Table C.1 - 2009 - Data for DEA inputs and outputs

\begin{tabular}{|c|c|c|c|c|c|c|}
\hline \multicolumn{2}{|c|}{2009} & Net Annual & Expenditure in & Environmental & Social & Governance \\
\hline DMU & CSS & $(\mathrm{R} \$ \mathrm{MM})$ & $(\mathrm{R} \$ \mathrm{MM})$ & Score & Score & Score \\
\hline 1 & CEEB3 & 3350.76 & 66.15 & 34.88 & 77.19 & 48.21 \\
\hline 2 & CELP3 & 1408.23 & 13.73 & 24.03 & 63.16 & 19.64 \\
\hline 3 & CEPE3 & 2914.84 & 50.91 & 31.01 & 75.44 & 53.57 \\
\hline 4 & CESP3 & 2652.81 & 41.98 & 17.05 & 56.14 & 42.86 \\
\hline 5 & CLSC3 & 3363.32 & 74.17 & 19.38 & 64.91 & 30.36 \\
\hline 6 & CMGR3 & 1364.35 & 15.37 & 20.93 & 57.89 & 14.29 \\
\hline 7 & CMIG3 & 11705.08 & 90.32 & 41.86 & 78.95 & 53.57 \\
\hline 8 & COCE3 & 2419.29 & 18.58 & 29.46 & 71.93 & 44.64 \\
\hline 9 & CPFE3 & 11358.01 & 159.38 & 17.05 & 78.95 & 48.21 \\
\hline 10 & CPLE3 & 6250.14 & 163.97 & 31.78 & 54.39 & 44.64 \\
\hline 11 & EKTR3 & 3120.34 & 48.85 & 35.66 & 77.19 & 33.93 \\
\hline 12 & ELET3 & 24581.03 & 165.65 & 28.68 & 75.44 & 37.50 \\
\hline 13 & ELPL3 & 8785.64 & 68.41 & 33.33 & 77.19 & 48.21 \\
\hline 14 & ENBR3 & 4648.35 & 29.22 & 60.47 & 92.98 & 73.21 \\
\hline 15 & ENGI3 & 1996.57 & 16.27 & 12.40 & 52.63 & 26.79 \\
\hline 16 & GETI3 & 1669.87 & 21.67 & 31.78 & 50.88 & 39.29 \\
\hline 17 & GPAR3 & 2028.29 & 40.33 & 27.91 & 63.16 & 25.00 \\
\hline 18 & LIGT3 & 6206.90 & 19.97 & 42.64 & 85.96 & 39.29 \\
\hline 19 & REDE3 & 5747.40 & 50.64 & 27.13 & 66.67 & 50.00 \\
\hline 20 & TBLE3 & 3496.68 & 67.15 & 45.74 & 38.60 & 55.36 \\
\hline
\end{tabular}


Table C.2 - 2010 - Data for DEA inputs and outputs

\begin{tabular}{|c|c|c|c|c|c|c|}
\hline \multicolumn{2}{|c|}{2010} & Net Annual & Expenditure in & Environmental & Social & Governance \\
\hline DMU & CSS & $(\mathrm{R} \$ \mathrm{MM})$ & $(\mathrm{R} \$ \mathrm{MM})$ & Score & Score & Score \\
\hline 1 & CEEB3 & 4394.30 & 121.67 & 37.98 & 71.93 & 37.50 \\
\hline 2 & CELP3 & 2433.80 & 15.44 & 20.93 & 63.16 & 23.21 \\
\hline 3 & CEPE3 & 2860.07 & 62.52 & 31.01 & 75.44 & 53.57 \\
\hline 4 & CESP3 & 2905.33 & 52.28 & 24.81 & 50.88 & 48.21 \\
\hline 5 & CLSC3 & 3603.67 & 111.73 & 19.38 & 75.44 & 42.86 \\
\hline 6 & CMGR3 & 1956.59 & 17.57 & 27.91 & 66.67 & 28.57 \\
\hline 7 & CMIG3 & 11476.13 & 88.05 & 47.29 & 84.21 & 53.57 \\
\hline 8 & COCE3 & 2849.71 & 42.54 & 50.39 & 91.23 & 58.93 \\
\hline 9 & CPFE3 & 12023.73 & 181.74 & 25.58 & 82.46 & 51.79 \\
\hline 10 & CPLE3 & 6901.11 & 134.73 & 32.56 & 57.89 & 44.64 \\
\hline 11 & EKTR3 & 3368.86 & 46.51 & 40.31 & 87.72 & 53.57 \\
\hline 12 & ELET3 & 25166.79 & 205.00 & 45.74 & 56.14 & 53.57 \\
\hline 13 & ELPL3 & 9697.16 & 76.61 & 33.33 & 85.96 & 44.64 \\
\hline 14 & ENBR3 & 5034.32 & 28.81 & 62.02 & 92.98 & 71.43 \\
\hline 15 & ENGI3 & 2154.32 & 22.05 & 14.73 & 52.63 & 21.43 \\
\hline 16 & EQTL3 & 1798.88 & 44.32 & 26.36 & 57.89 & 44.64 \\
\hline 17 & GETI3 & 1754.35 & 13.05 & 34.11 & 70.18 & 48.21 \\
\hline 18 & GPAR3 & 2163.75 & 29.42 & 26.36 & 63.16 & 37.50 \\
\hline 19 & LIGT3 & 6508.58 & 28.68 & 46.51 & 77.19 & 44.64 \\
\hline 20 & REDE3 & 6860.73 & 55.17 & 24.81 & 70.18 & 48.21 \\
\hline 21 & TBLE3 & 4100.38 & 39.96 & 65.12 & 66.67 & 58.93 \\
\hline
\end{tabular}


Table C.3 - 2011 - Data for DEA inputs and outputs

\begin{tabular}{|c|c|c|c|c|c|c|}
\hline \multicolumn{2}{|c|}{2011} & \multirow{2}{*}{$\begin{array}{c}\text { Net Annual } \\
\text { Revenue } \\
\text { (R\$ MM) }\end{array}$} & \multirow{2}{*}{$\begin{array}{c}\text { Expenditure in } \\
\text { Environ. Activs } \\
\text { (R\$ MM) }\end{array}$} & \multirow{2}{*}{$\begin{array}{c}\text { Environmental } \\
\text { Disclosure } \\
\text { Score }\end{array}$} & \multirow{2}{*}{$\begin{array}{c}\text { Social } \\
\text { Disclosure } \\
\text { Score }\end{array}$} & \multirow{2}{*}{$\begin{array}{c}\text { Governance } \\
\text { Disclosure } \\
\text { Score } \\
\end{array}$} \\
\hline DMU & CSS & & & & & \\
\hline 1 & CEEB3 & 4967.40 & 81.84 & 35.66 & 82.46 & 46.43 \\
\hline 2 & CELP3 & 2349.95 & 16.54 & 31.01 & 61.40 & 37.50 \\
\hline 3 & CEPE3 & 2914.10 & 72.56 & 27.91 & 71.93 & 51.79 \\
\hline 4 & CESP3 & 2957.53 & 39.45 & 24.03 & 71.93 & 62.50 \\
\hline 5 & CLSC3 & 4191.41 & 94.34 & 23.26 & 70.18 & 42.86 \\
\hline 6 & CMGR3 & 2009.77 & 17.05 & 27.91 & 63.16 & 35.71 \\
\hline 7 & CMIG3 & 15748.72 & 116.53 & 49.61 & 78.95 & 62.50 \\
\hline 8 & CPFE3 & 12764.03 & 105.13 & 31.01 & 77.19 & 48.21 \\
\hline 9 & CPLE3 & 7776.17 & 200.92 & 41.86 & 71.93 & 46.43 \\
\hline 10 & EKTR3 & 3564.09 & 51.67 & 39.53 & 78.95 & 58.93 \\
\hline 11 & ELET3 & 25865.27 & 229.14 & 48.84 & 66.67 & 57.14 \\
\hline 12 & ELPL3 & 9835.58 & 72.30 & 38.76 & 82.46 & 62.50 \\
\hline 13 & ENBR3 & 5401.66 & 29.41 & 62.02 & 87.72 & 80.36 \\
\hline 14 & ENGI3 & 2426.61 & 42.04 & 17.05 & 52.63 & 26.79 \\
\hline 15 & EQTL3 & 1980.53 & 7.61 & 21.71 & 57.89 & 25.00 \\
\hline 16 & GETI3 & 1885.96 & 12.55 & 36.43 & 71.93 & 51.79 \\
\hline 17 & LIGT3 & 6944.79 & 41.93 & 50.39 & 78.95 & 53.57 \\
\hline 18 & TBLE3 & 4326.95 & 77.38 & 55.04 & 66.67 & 62.50 \\
\hline
\end{tabular}


Table C.4 - 2012 - Data for DEA inputs and outputs

\begin{tabular}{|c|c|c|c|c|c|c|}
\hline \multicolumn{2}{|c|}{2012} & Net Annual & Expenditure in & Environmental & Social & Governance \\
\hline DMU & CSS & $(\mathrm{R} \$ \mathrm{MM})$ & $(\mathrm{R} \$ \mathrm{MM})$ & Score & Score & Score \\
\hline 1 & CEEB3 & 5813.60 & 89.84 & 36.43 & 78.95 & 48.21 \\
\hline 2 & CEPE3 & 3545.90 & 14.29 & 39.26 & 37.21 & 68.42 \\
\hline 3 & CESP3 & 3354.01 & 25.92 & 31.78 & 77.19 & 44.64 \\
\hline 4 & CLSC3 & 4545.21 & 150.82 & 28.68 & 71.93 & 39.29 \\
\hline 5 & CMIG3 & 18460.38 & 163.18 & 38.76 & 63.16 & 53.57 \\
\hline 6 & CPFE3 & 14890.88 & 92.98 & 25.58 & 78.95 & 48.21 \\
\hline 7 & CPLE3 & 8493.25 & 275.15 & 46.51 & 68.42 & 19.64 \\
\hline 8 & ELET3 & 34064.48 & 319.90 & 50.39 & 66.67 & 58.93 \\
\hline 9 & ELPL3 & 9959.20 & 57.08 & 39.53 & 77.19 & 48.21 \\
\hline 10 & ENBR3 & 6567.28 & 44.74 & 48.84 & 82.46 & 57.14 \\
\hline 11 & EQTL3 & 2884.50 & 31.31 & 28.68 & 63.16 & 39.29 \\
\hline 12 & GETI3 & 2112.44 & 10.35 & 34.11 & 77.19 & 7.14 \\
\hline 13 & TBLE3 & 4912.50 & 56.31 & 55.04 & 66.67 & 44.64 \\
\hline
\end{tabular}




\section{Appendix D - Publicly traded assets available for portfolio formation and test results for stationarity and normality}

Observations:

CSS denotes the common stock symbol of the company;

a, b ADF null hypothesis not accepted at the 1\% and 5\% significance level, respectively;

${ }^{\mathrm{c}, \mathrm{d}}$ KPSS null hypothesis not rejected at the $1 \%$ and $5 \%$ significance level, respectively;

e, f JB null hypothesis not accepted at the $1 \%$ and $5 \%$ significance level, respectively.

\begin{tabular}{|c|c|c|c|c|}
\hline CSS & Securities & $\begin{array}{r}\mathrm{ADF} \tau \\
\text { statistic } \\
\end{array}$ & $\begin{array}{r}\text { KPSS LM } \\
\text { statistic } \\
\end{array}$ & $\begin{array}{r}\text { JB } \\
\text { statistic } \\
\end{array}$ \\
\hline AELP3 & AELP3 & -28.26 & $0.99 \mathrm{~d}$ & 67275.64 \\
\hline AFLT3 & AFLT3 & -18.47 & $0.02^{\mathrm{d}}$ & 8688103.00 \\
\hline AFLU3 & AFLU3 & -35.25 & $0.13^{\mathrm{d}}$ & 4943592.00 \\
\hline CBEE3 & CBEE3 & -38.35 & $0.12^{\mathrm{d}}$ & 5007.08 \\
\hline CEBR3 & CEBR3 & -27.74 & $0.24^{\mathrm{d}}$ & 102908.60 \\
\hline CEEB3 & CEEB3 & -38.21 & $0.43^{\mathrm{d}}$ & 21666.09 \\
\hline CEED3 & CEED3 & -31.31 & $0.04^{\mathrm{d}}$ & 293872.00 \\
\hline \multirow{2}{*}{ CELP3 } & CELP3 & -7.15 & $0.13^{\mathrm{d}}$ & 1511616.00 \\
\hline & CELP5 & -35.73 & $0.25^{\mathrm{d}}$ & 7247405.00 \\
\hline CEPE3 & CEPE5 & -42.47 & $0.42^{\mathrm{d}}$ & 126177.60 \\
\hline \multirow{3}{*}{ CESP3 } & CESP3 & -39.90 & $0.31^{\mathrm{d}}$ & 72724.35 \\
\hline & CESP5 & -30.93 & $0.35^{\mathrm{d}}$ & 10053.91 \\
\hline & CESP6 & -36.83 & $0.21 \mathrm{~d}$ & 52649.97 \\
\hline CLSC3 & CLSC3 & -20.52 & $0.10^{\mathrm{d}}$ & 11313955.00 \\
\hline \multirow{2}{*}{ CMGR3 } & CMGR3 & -37.72 & $0.06^{\mathrm{d}}$ & 57685.01 \\
\hline & CMGR4 & -34.01 & $0.09 \mathrm{~d}$ & 78157.73 \\
\hline \multirow{2}{*}{ CMIG3 } & CMIG3 & -38.64 & $0.17^{\mathrm{d}}$ & 146262.90 \\
\hline & CMIG4 & -40.53 & $0.06^{\mathrm{d}}$ & 104932.80 \\
\hline \multirow{2}{*}{ COCE3 } & COCE3 & -22.33 & $0.09 \mathrm{~d}$ & 15578.48 \\
\hline & COCE5 & -35.65 & $0.03 \mathrm{~d}$ & 6951.01 \\
\hline CPFE3 & CPFE3 & -39.78 & $0.38 \mathrm{~d}$ & 19.38 \\
\hline \multirow{2}{*}{ CPLE3 } & CPLE3 & -41.86 & $0.33 \mathrm{~d}$ & 7525.00 \\
\hline & CPLE6 & -36.78 & $0.24 \mathrm{~d}$ & 4869.96 \\
\hline CSRN3 & CSRN3 & -19.18 & $0.18^{\mathrm{d}}$ & 15267371.00 \\
\hline \multirow{2}{*}{ EEEL3 } & EEEL3 & -17.29 & $0.19^{\mathrm{d}}$ & 67012.53 \\
\hline & EEEL4 & -26.25 & $0.04^{\mathrm{d}}$ & 242854.40 \\
\hline EKTR3 & EKTR4 & -36.48 & $0.47^{\mathrm{c}}$ & 12412.91 \\
\hline ELET3 & ELET3 & -32.91 & $0.16^{\mathrm{d}}$ & 39737.18 \\
\hline
\end{tabular}




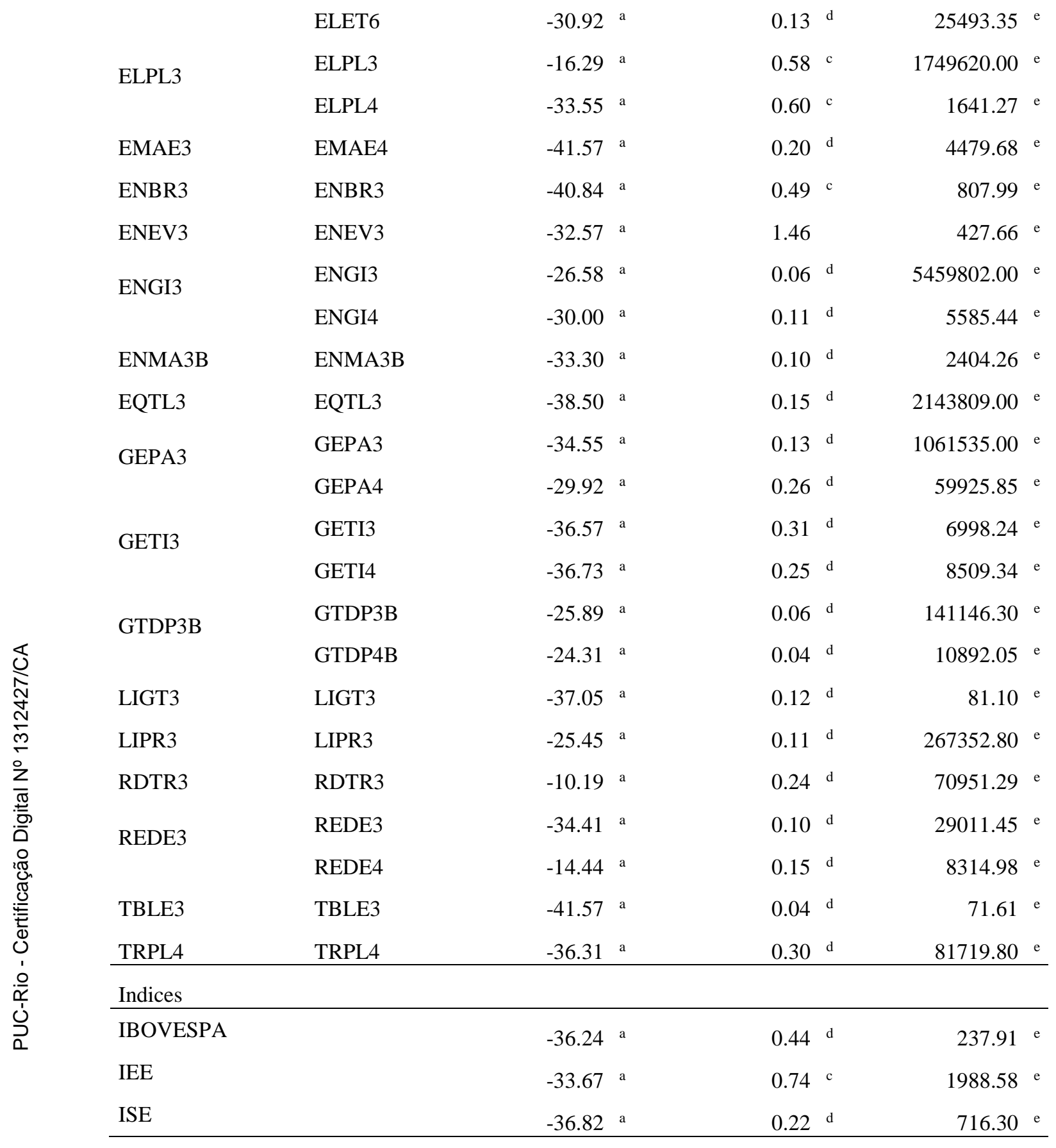




\section{Appendix E - Formed portfolios}

Observations:

CSS denotes the common stock symbol of the company;

DEA TE: DEA technical efficiency values.

(starts on the next page) 
2009 Portfolios

\begin{tabular}{|c|c|c|c|c|c|c|c|c|c|c|}
\hline & CSS & DEA TE & Port & io A & Portf & io B & Port & io $\mathrm{C}$ & Portf & io D \\
\hline & & & stocks & $\%$ share & stocks & $\%$ share & stocks & $\%$ share & stocks & $\%$ share \\
\hline & CEEB3 & 1.000 & CEEB3 & 0.103 & CEEB3 & 0.100 & CEEB3 & 0.249 & CEEB3 & 0.025 \\
\hline & CEPE3 & 1.000 & CEPE5 & 0.103 & CEPE5 & 0.100 & CEPE5 & 0.155 & CEPE5 & 0.327 \\
\hline & CLSC3 & 0.961 & CLSC3 & 0.099 & CLSC3 & 0.100 & CLSC3 & 0.191 & CLSC3 & 0.025 \\
\hline & CMLG3 & 0800 & CMIG3 & 0.046 & CMIG3 & 0.050 & CMIG3 & 0.025 & CMIG3 & 0.025 \\
\hline छे & & & CMIG4 & 0.046 & CMIG4 & 0.050 & CMIG4 & 0.025 & CMIG4 & 0.025 \\
\hline $\begin{array}{l}50 \\
5\end{array}$ & CPFE3 & 0.984 & CPFE3 & 0.101 & CPFE3 & 0.100 & CPFE3 & 0.098 & CPFE3 & 0.031 \\
\hline & CPLE3 & 1.000 & CPLE3 & 0.103 & CPLE3 & 0.100 & CPLE3 & 0.070 & CPLE3 & 0.281 \\
\hline & EKTR3 & 0.976 & EKTR4 & 0.100 & EKTR4 & 0.100 & EKTR4 & 0.025 & EKTR4 & 0.031 \\
\hline & ENBR3 & 1.000 & ENBR3 & 0.103 & ENBR3 & 0.100 & ENBR3 & 0.025 & ENBR3 & 0.179 \\
\hline & LIGT3 & 0.925 & LIGT3 & 0.095 & LIGT3 & 0.100 & LIGT3 & 0.057 & LIGT3 & 0.025 \\
\hline & TBLE3 & 1.000 & TBLE3 & 0.103 & TBLE3 & 0.100 & TBLE3 & 0.079 & TBLE3 & 0.025 \\
\hline & & & & & & & & & & \\
\hline & CELP3 & 0.745 & CELP5 & 0.109 & CELP5 & 0.111 & CELP5 & 0.349 & CELP5 & 0.025 \\
\hline & & & CESP3 & 0.038 & CESP3 & 0.037 & CESP3 & 0.025 & CESP3 & 0.099 \\
\hline$\delta$ & CESP3 & 0.778 & CESP5 & 0.038 & CESP5 & 0.037 & CESP5 & 0.025 & CESP5 & 0.025 \\
\hline$\stackrel{N}{N}$ & & & CESP6 & 0.038 & CESP6 & 0.037 & CESP6 & 0.025 & CESP6 & 0.025 \\
\hline$\frac{d}{n}$ & CMGR3 & 0.700 & CMGR3 & 0.051 & CMGR3 & 0.056 & CMGR3 & 0.025 & CMGR3 & 0.025 \\
\hline ol & & & CMGR4 & 0.051 & CMGR4 & 0.056 & CMGR4 & 0.025 & CMGR4 & 0.025 \\
\hline$\frac{2}{\pi}$ & COCE3 & 0.810 & COCE3 & 0.059 & COCE3 & 0.056 & COCE3 & 0.025 & COCE3 & 0.100 \\
\hline 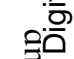 & & & COCE5 & 0.059 & COCE5 & 0.056 & COCE5 & 0.049 & COCE5 & 0.025 \\
\hline 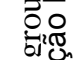 & ELET3 & 0.825 & ELET3 & 0.060 & ELET3 & 0.056 & ELET3 & 0.025 & ELET3 & 0.025 \\
\hline שֶ. & & & ELET6 & 0.060 & ELET6 & 0.056 & ELET6 & 0.059 & ELET6 & 0.025 \\
\hline 证 & ELPL3 & 0.872 & ELPL3 & 0.064 & ELPL3 & 0.056 & ELPL3 & 0.096 & ELPL3 & 0.126 \\
\hline & & & ELPL4 & 0.064 & ELPL4 & 0.056 & ELPL4 & 0.025 & ELPL4 & 0.025 \\
\hline r & ENGI3 & 0.600 & ENGI3 & 0.044 & ENGI3 & 0.056 & ENGI3 & 0.025 & ENGI3 & 0.025 \\
\hline 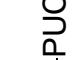 & & & ENGI4 & 0.044 & ENGI4 & 0.056 & ENGI4 & 0.066 & ENGI4 & 0.226 \\
\hline & GETI3 & 0.723 & GETI3 & 0.053 & GETI3 & 0.056 & GETI3 & 0.070 & GETI3 & 0.124 \\
\hline & & & GETI4 & 0.053 & GETI4 & 0.056 & GETI4 & 0.035 & GETI4 & 0.025 \\
\hline & GPAR3 & 0.825 & GPAR3 & 0.000 & GPAR3 & 0.000 & GPAR3 & 0.000 & GPAR3 & 0.000 \\
\hline & REDE3 & 0.781 & REDE3 & 0.057 & REDE3 & 0.056 & REDE3 & 0.025 & REDE3 & 0.025 \\
\hline & & & REDE4 & 0.057 & REDE4 & 0.056 & REDE4 & 0.025 & REDE4 & 0.025 \\
\hline & AFI T3 & 0000 & AFI T3 & 0125 & AFI T3 & 0125 & AFI T3 & 0025 & AFI T3 & \\
\hline & AFLU3 & 0.000 & AFLU3 & 0.125 & AFLU3 & 0.125 & AFLU3 & 0.055 & AFLU3 & 0.025 \\
\hline & CBEE3 & 0.000 & CBEE3 & 0.125 & CBEE3 & 0.125 & CBEE3 & 0.025 & CBEE3 & 0.095 \\
\hline పू. & CSRN3 & 0.000 & CSRN3 & 0.125 & CSRN3 & 0.125 & CSRN3 & 0.117 & CSRN3 & 0.090 \\
\hline.$\Xi$ & EMAE4 & 0.000 & EMAE4 & 0.125 & EMAE4 & 0.125 & EMAE4 & 0.049 & EMAE4 & 0.206 \\
\hline & GEPA4 & 0.000 & GEPA4 & 0.125 & GEPA4 & 0.125 & GEPA4 & 0.048 & GEPA4 & 0.172 \\
\hline & GETI3 & 0.000 & GETI3 & 0.125 & GETI3 & 0.125 & GETI3 & 0.130 & GETI3 & 0.362 \\
\hline & LIPR3 & 0.000 & LIPR3 & 0.125 & LIPR3 & 0.125 & LIPR3 & 0.551 & LIPR3 & 0.025 \\
\hline
\end{tabular}


2010 Portfolios

\begin{tabular}{|c|c|c|c|c|c|c|c|c|c|c|}
\hline & CSS & DFA TF & Port & io $\mathrm{A}$ & Port & io B & Port & io $\mathrm{C}$ & Port & io D \\
\hline & & & stocks & $\%$ share & stocks & $\%$ share & stocks & $\%$ share & stocks & $\%$ share \\
\hline & CEEB3 & 1.000 & CEEB3 & 0.094 & CEEB3 & 0.091 & CEEB3 & 0.061 & CEEB3 & 0.046 \\
\hline & CEPE3 & 1.000 & CEPE5 & 0.094 & CEPE5 & 0.091 & CEPE5 & 0.038 & CEPE5 & 0.025 \\
\hline & CLSC3 & 1.000 & CLSC 3 & 0.094 & CLSC 3 & 0.091 & CLSC 3 & 0.386 & CLSC 3 & 0.160 \\
\hline & CMIG3 & 0.913 & CMIG3 & 0.086 & CMIG3 & 0.091 & CMIG3 & 0.036 & CMIG3 & 0.025 \\
\hline ‡ & COCE3 & 1.000 & COCE5 & 0.094 & COCE5 & 0.091 & COCE5 & 0.130 & COCE5 & 0.025 \\
\hline $\begin{array}{l}50 \\
50 \\
0.0\end{array}$ & CPFE3 & 0.908 & CPFE3 & 0.085 & CPFE3 & 0.091 & CPFE3 & 0.097 & CPFE3 & 0.264 \\
\hline 江 & EKTR3 & 0.961 & EKTR4 & 0.090 & EKTR4 & 0.091 & EKTR4 & 0.025 & EKTR4 & 0.025 \\
\hline & ELPL3 & 0.932 & ELPL4 & 0.088 & ELPL4 & 0.091 & ELPL4 & 0.025 & ELPL4 & 0.025 \\
\hline & ENBR3 & 1.000 & ENBR3 & 0.094 & ENBR3 & 0.091 & ENBR3 & 0.070 & ENBR3 & 0.220 \\
\hline & EQTL3 & 0.923 & EQTL3 & 0.087 & EQTL3 & 0.091 & EQTL3 & 0.025 & EQTL3 & 0.025 \\
\hline & TBLE3 & 1.000 & TBLE3 & 0.094 & TBLE3 & 0.091 & TBLE3 & 0.107 & TBLE3 & 0.160 \\
\hline & CEI P3 & 0090 & CEI P5 & 0090 & CEI P5 & 0111 & CELP5 & 0025 & CEI P5 & 0025 \\
\hline & CГС & (2) & CESP3 & 0.063 & CESP3 & 0.056 & CESP3 & 0.025 & CESP3 & 0.025 \\
\hline 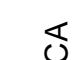 & CEST & 0.125 & CESP5 & 0.063 & CESP5 & 0.056 & CESP5 & 0.045 & CESP5 & 0.025 \\
\hline N & CMGR3 & 0106 & CMGR3 & 0.053 & CMGR3 & 0.056 & CMGR3 & 0.031 & CMGR3 & 0.025 \\
\hline$\stackrel{\text { N }}{\mathbf{N}}$ & & & CMGR4 & 0.053 & CMGR4 & 0.056 & CMGR4 & 0.025 & CMGR4 & 0.025 \\
\hline$\stackrel{m}{\frac{m}{2}}$ & CPIF3 & 0123 & CPLE3 & 0.062 & CPLE3 & 0.056 & CPLE3 & 0.064 & CPLE3 & 0.025 \\
\hline$=\frac{2}{\pi}$ & & & CPLE6 & 0.062 & CPLE6 & 0.056 & CPLE6 & 0.081 & CPLE6 & 0.025 \\
\hline 흠흠 & FIFT3 & 0119 & ELET3 & 0.060 & ELET3 & 0.056 & ELET3 & 0.025 & ELET3 & 0.025 \\
\hline$\overline{7} \approx \pi$ & & & ELET6 & 0.060 & ELET6 & 0.056 & ELET6 & 0.027 & ELET6 & 0.025 \\
\hline ర్ల & FNGI3 & 0084 & ENGI3 & 0.042 & ENGI3 & 0.056 & ENGI3 & 0.025 & ENGI3 & 0.025 \\
\hline$\frac{\bar{F}}{0}$ & & & ENGI4 & 0.042 & ENGI4 & 0.056 & ENGI4 & 0.072 & ENGI4 & 0.025 \\
\hline 0 & GFTI3 & 0111 & GETI3 & 0.055 & GETI3 & 0.056 & GETI3 & 0.202 & GETI3 & 0.505 \\
\hline $\bar{r}$ & & & GETI4 & 0.055 & GETI4 & 0.056 & GETI4 & 0.158 & GETI4 & 0.145 \\
\hline 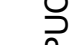 & GPAR3 & 0.000 & GPAR3 & 0.000 & GPAR3 & 0.000 & GPAR3 & 0.000 & GPAR3 & 0.000 \\
\hline & LIGT3 & 0.121 & LIGT3 & 0.121 & LIGT3 & 0.111 & LIGT3 & 0.142 & LIGT3 & 0.025 \\
\hline & 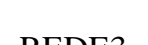 & 011 & REDE3 & 0.056 & REDE3 & 0.056 & REDE3 & 0.028 & REDE3 & 0.025 \\
\hline & & & REDE4 & 0.056 & REDE4 & 0.056 & REDE4 & 0.025 & REDE4 & 0.025 \\
\hline & & & & & & & & & & \\
\hline & AFLT3 & 0.000 & AFLT3 & 0.091 & AFLT3 & 0.091 & AFLT3 & 0.025 & AFLT3 & 0.025 \\
\hline & AFLU3 & 0.000 & AFLU3 & 0.091 & AFLU3 & 0.091 & AFLU3 & 0.107 & AFLU3 & 0.025 \\
\hline & CBEE3 & 0.000 & CBEE3 & 0.091 & CBEE3 & 0.091 & CBEE3 & 0.025 & CBEE3 & 0.025 \\
\hline & CEBR3 & 0.000 & CEBR3 & 0.091 & CEBR3 & 0.091 & CEBR3 & 0.025 & CEBR3 & 0.025 \\
\hline & CSRN3 & 0.000 & CSRN3 & 0.091 & CSRN3 & 0.091 & CSRN3 & 0.025 & CSRN3 & 0.085 \\
\hline పे & FFFI 3 & 0000 & EEEL3 & 0.045 & EEEL3 & 0.045 & EEEL3 & 0.025 & EEEL3 & 0.025 \\
\hline$\overbrace{0}^{\infty+\infty}$ & & & EEEL4 & 0.045 & EEEL4 & 0.045 & EEEL4 & 0.028 & EEEL4 & 0.025 \\
\hline 节 & EMAE4 & 0.000 & EMAE4 & 0.091 & EMAE4 & 0.091 & EMAE4 & 0.123 & EMAE4 & 0.025 \\
\hline & ENEV3 & 0.000 & ENEV3 & 0.091 & ENEV3 & 0.091 & ENEV3 & 0.027 & ENEV3 & 0.025 \\
\hline & GEPA 3 & 0000 & GEPA3 & 0.045 & GEPA3 & 0.045 & GEPA3 & 0.051 & GEPA3 & 0.025 \\
\hline & & & GEPA4 & 0.045 & GEPA4 & 0.045 & GEPA4 & 0.025 & GEPA4 & 0.640 \\
\hline & LIPR3 & 0.000 & LIPR3 & 0.091 & LIPR3 & 0.091 & LIPR3 & 0.261 & LIPR3 & 0.025 \\
\hline & TRPL4 & 0.000 & TRPL4 & 0.091 & TRPL4 & 0.091 & TRPL4 & 0.253 & TRPL4 & 0.025 \\
\hline
\end{tabular}


2011 Portfolios

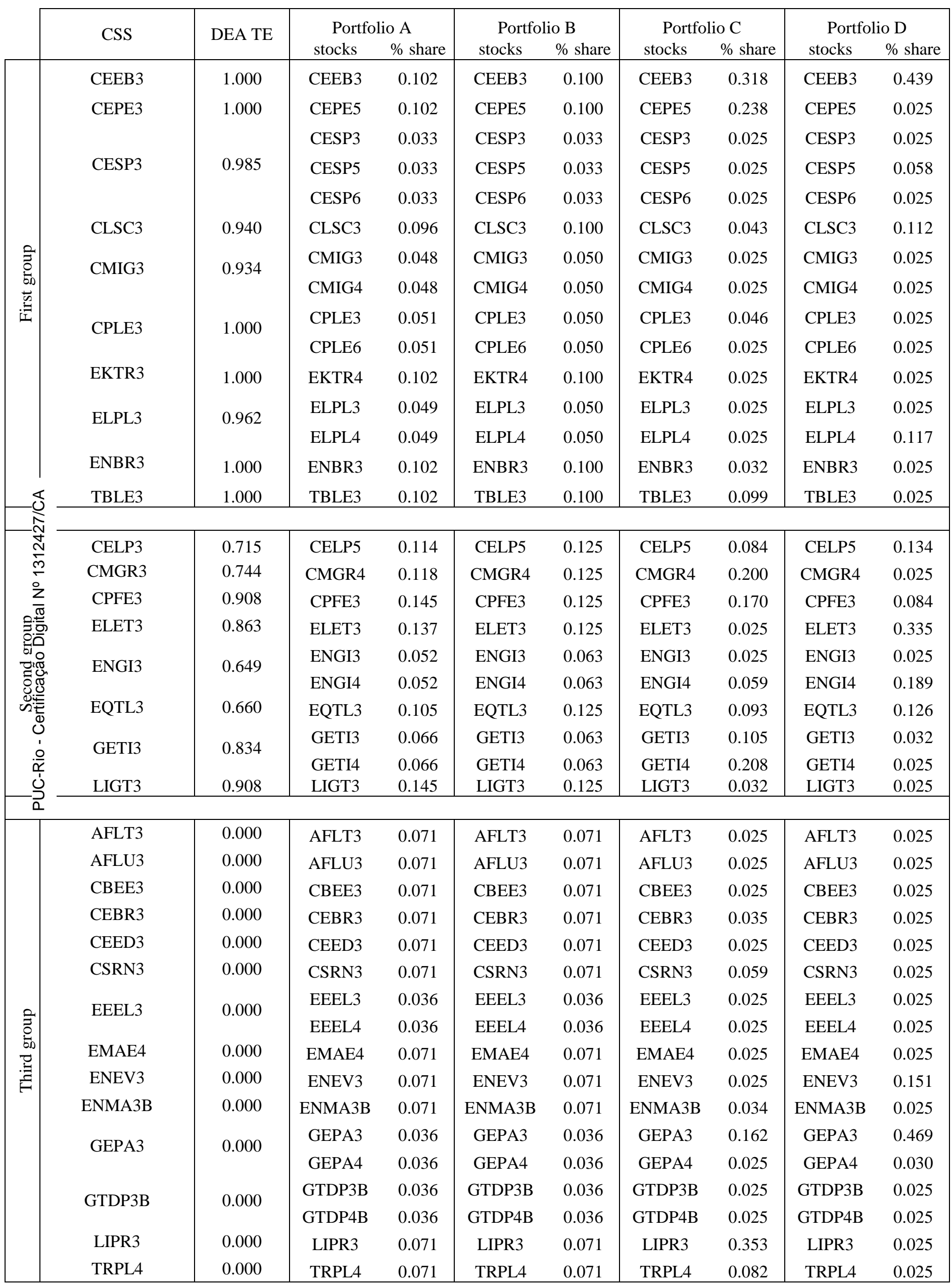


2012 Portfolios

\begin{tabular}{|c|c|c|c|c|c|c|c|c|c|c|}
\hline & \multirow{2}{*}{ CSS } & \multirow{2}{*}{ DEA TE } & \multicolumn{2}{|c|}{ Portfolio A } & \multicolumn{2}{|c|}{ Portfolio B } & \multicolumn{2}{|c|}{ Portfolio C } & \multicolumn{2}{|c|}{ Portfolio D } \\
\hline & & & stocks & $\%$ share & stocks & $\%$ share & stocks & $\%$ share & stocks & $\%$ share \\
\hline \multirow{9}{*}{ 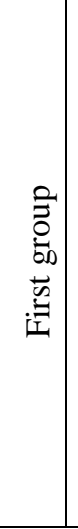 } & CEEB3 & 1.000 & CEEB3 & 0.143 & CEEB3 & 0.143 & CEEB3 & 0.371 & CEEB3 & 0.025 \\
\hline & CEPE3 & 1.000 & CEPE5 & 0.143 & CEPE5 & 0.143 & CEPE5 & 0.026 & CEPE5 & 0.025 \\
\hline & CLSC3 & 1.000 & CLSC3 & 0.143 & CLSC3 & 0.143 & CLSC3 & 0.025 & CLSC3 & 0.025 \\
\hline & \multirow{2}{*}{ CPLE3 } & \multirow{2}{*}{1.000} & CPLE3 & 0.071 & CPLE3 & 0.071 & CPLE3 & 0.062 & CPLE3 & 0.025 \\
\hline & & & CPLE6 & 0.071 & CPLE6 & 0.071 & CPLE6 & 0.058 & CPLE6 & 0.025 \\
\hline & \multirow{2}{*}{ ELET3 } & \multirow{2}{*}{1.000} & ELET3 & 0.071 & ELET3 & 0.071 & ELET3 & 0.025 & ELET3 & 0.025 \\
\hline & & & ELET6 & 0.071 & ELET6 & 0.071 & ELET6 & 0.025 & ELET6 & 0.025 \\
\hline & ENBR3 & 1.000 & ENBR3 & 0.143 & ENBR3 & 0.143 & ENBR3 & 0.163 & ENBR3 & 0.025 \\
\hline & TBLE3 & 1.000 & TBLE3 & 0.143 & TBLE3 & 0.143 & TBLE3 & 0.245 & TBLE3 & 0.800 \\
\hline & \multirow{4}{*}{ CESP3 } & \multirow{4}{*}{0.945} & & & & & & & & \\
\hline & & & CESP3 & 0.058 & CESP3 & 0.056 & CESP3 & 0.025 & CESP3 & 0.025 \\
\hline \multirow{25}{*}{ 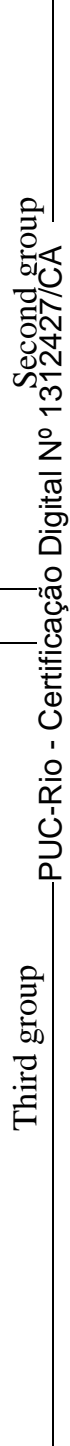 } & & & CESP5 & 0.058 & CESP5 & 0.056 & CESP5 & 0.025 & CESP5 & 0.025 \\
\hline & & & CESP6 & 0.058 & CESP6 & 0.056 & CESP6 & 0.025 & CESP6 & 0.025 \\
\hline & \multirow{2}{*}{ CMIG3 } & \multirow{2}{*}{0.913} & CMIG3 & 0.083 & CMIG3 & 0.083 & CMIG3 & 0.025 & CMIG3 & 0.025 \\
\hline & & & CMIG4 & 0.083 & CMIG4 & 0.083 & CMIG4 & 0.025 & CMIG4 & 0.025 \\
\hline & CPFE3 & 0.957 & CPFE3 & 0.175 & CPFE3 & 0.167 & CPFE3 & 0.329 & CPFE3 & 0.025 \\
\hline & \multirow{2}{*}{ ELPL3 } & \multirow{2}{*}{0.936} & ELPL3 & 0.085 & ELPL3 & 0.083 & ELPL3 & 0.178 & ELPL3 & 0.025 \\
\hline & & & ELPL4 & 0.085 & ELPL4 & 0.083 & ELPL4 & 0.065 & ELPL4 & 0.025 \\
\hline & EQTL3 & 0.788 & EQTL3 & 0.144 & EQTL3 & 0.167 & EQTL3 & 0.194 & EQTL3 & 0.750 \\
\hline & \multirow{2}{*}{ GETI3 } & \multirow{2}{*}{0.936} & GETI3 & 0.085 & GETI3 & 0.083 & GETI3 & 0.084 & GETI3 & 0.025 \\
\hline & & & GETI4 & 0.085 & GETI4 & 0.083 & GETI4 & 0.025 & GETI4 & 0.025 \\
\hline & & & & & & & & & & \\
\hline & AFLT3 & 0.000 & AFLT3 & 0.071 & AFLT3 & 0.071 & AFLT3 & 0.025 & AFLT3 & 0.025 \\
\hline & AFLU3 & 0.000 & AFLU3 & 0.071 & AFLU3 & 0.071 & AFLU3 & 0.025 & AFLU3 & 0.650 \\
\hline & CBEE3 & 0.000 & CBEE3 & 0.071 & CBEE3 & 0.071 & CBEE3 & 0.025 & CBEE3 & 0.025 \\
\hline & CEBR3 & 0.000 & CEBR3 & 0.071 & CEBR3 & 0.071 & CEBR3 & 0.025 & CEBR3 & 0.025 \\
\hline & CEED3 & 0.000 & CEED3 & 0.071 & CEED3 & 0.071 & CEED3 & 0.025 & CEED3 & 0.025 \\
\hline & CSRN3 & 0.000 & CSRN3 & 0.071 & CSRN3 & 0.071 & CSRN3 & 0.025 & CSRN3 & 0.025 \\
\hline & EEEL3 & 0.000 & EEEL3 & 0.071 & EEEL3 & 0.071 & EEEL3 & 0.025 & EEEL3 & 0.025 \\
\hline & EMAE4 & 0.000 & EMAE4 & 0.071 & EMAE4 & 0.071 & EMAE4 & 0.025 & EMAE4 & 0.025 \\
\hline & ENEV3 & 0.000 & ENEV3 & 0.071 & ENEV3 & 0.071 & ENEV3 & 0.025 & ENEV3 & 0.025 \\
\hline & ENMA3B & 0.000 & ENMA3B & 0.071 & ENMA3B & 0.071 & ENMA3B & 0.058 & ENMA3B & 0.025 \\
\hline & GTDP3B & 0.000 & GTDP3B & 0.036 & GTDP3B & 0.036 & GTDP3B & 0.025 & GTDP3B & 0.025 \\
\hline & & & GTDP4B & 0.036 & GTDP4B & 0.036 & GTDP4B & 0.025 & GTDP4B & 0.025 \\
\hline & LIPR3 & 0.000 & LIPR3 & 0.071 & LIPR3 & 0.071 & LIPR3 & 0.532 & LIPR3 & 0.025 \\
\hline & RDTR3 & 0.000 & RDTR3 & 0.071 & RDTR3 & 0.071 & RDTR3 & 0.110 & RDTR3 & 0.025 \\
\hline & TRPL4 & 0.000 & TRPL4 & 0.071 & TRPL4 & 0.071 & TRPL4 & 0.025 & TRPL4 & 0.025 \\
\hline
\end{tabular}




\section{Appendix F - Formed portfolios - ex-post graphs}

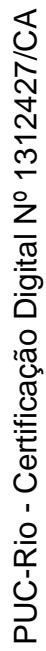
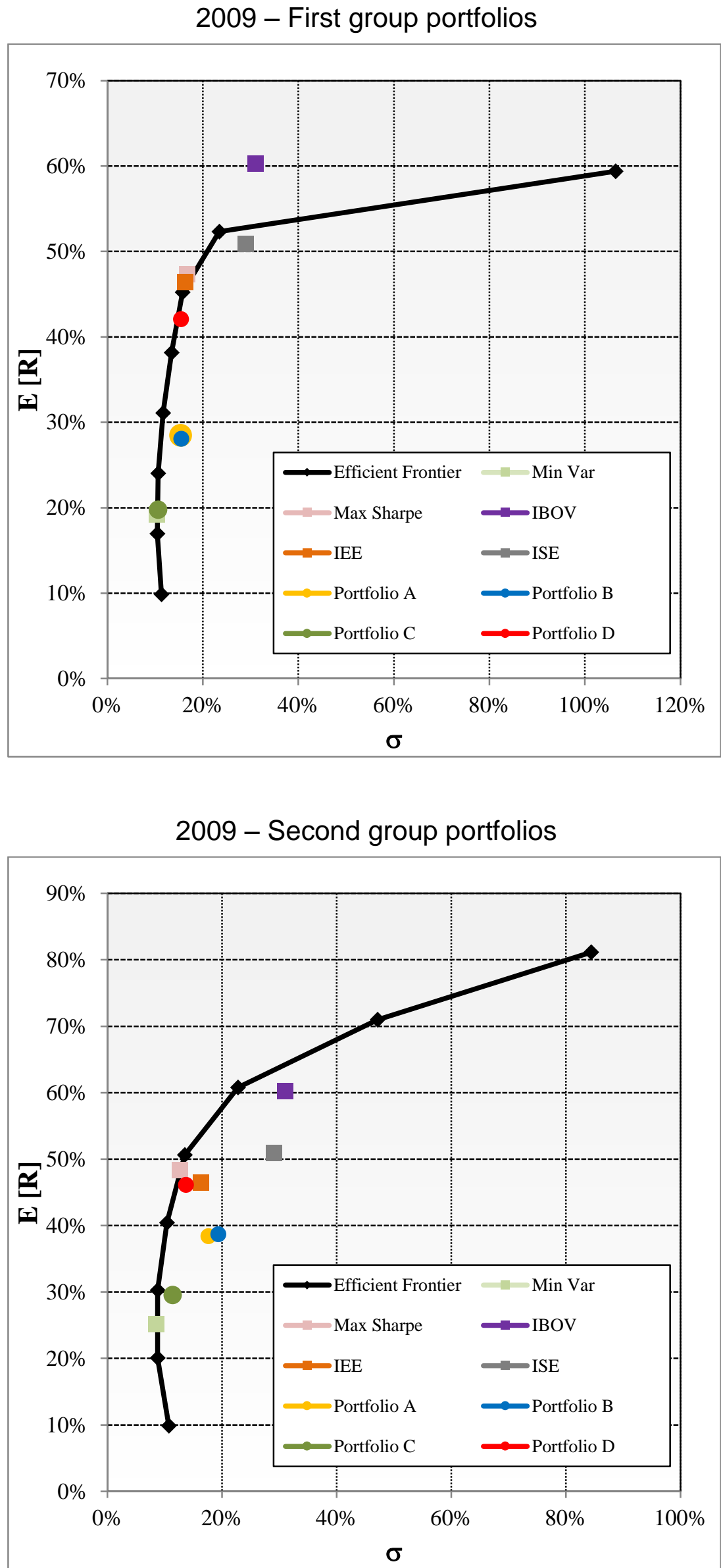


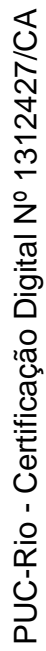
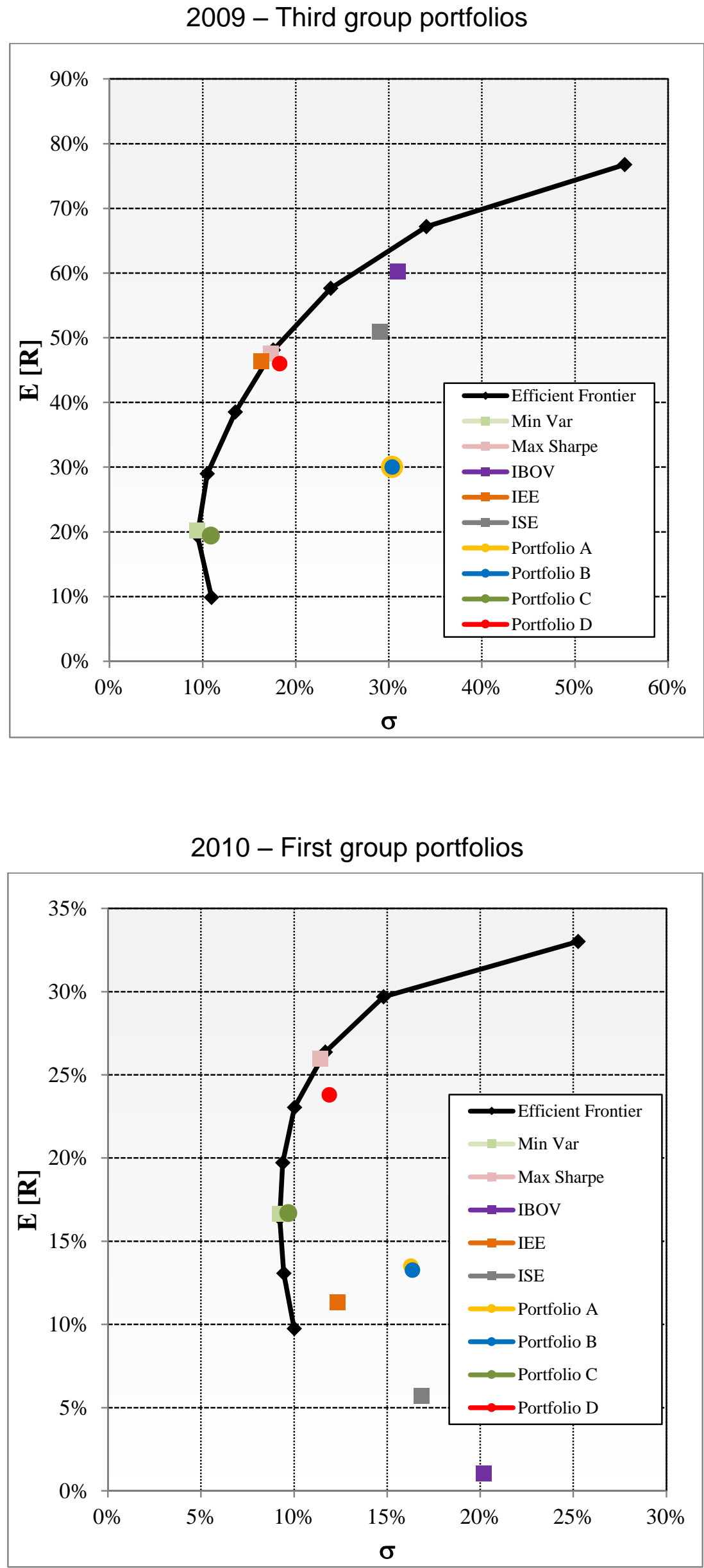


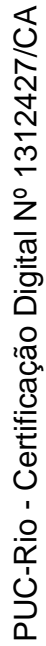
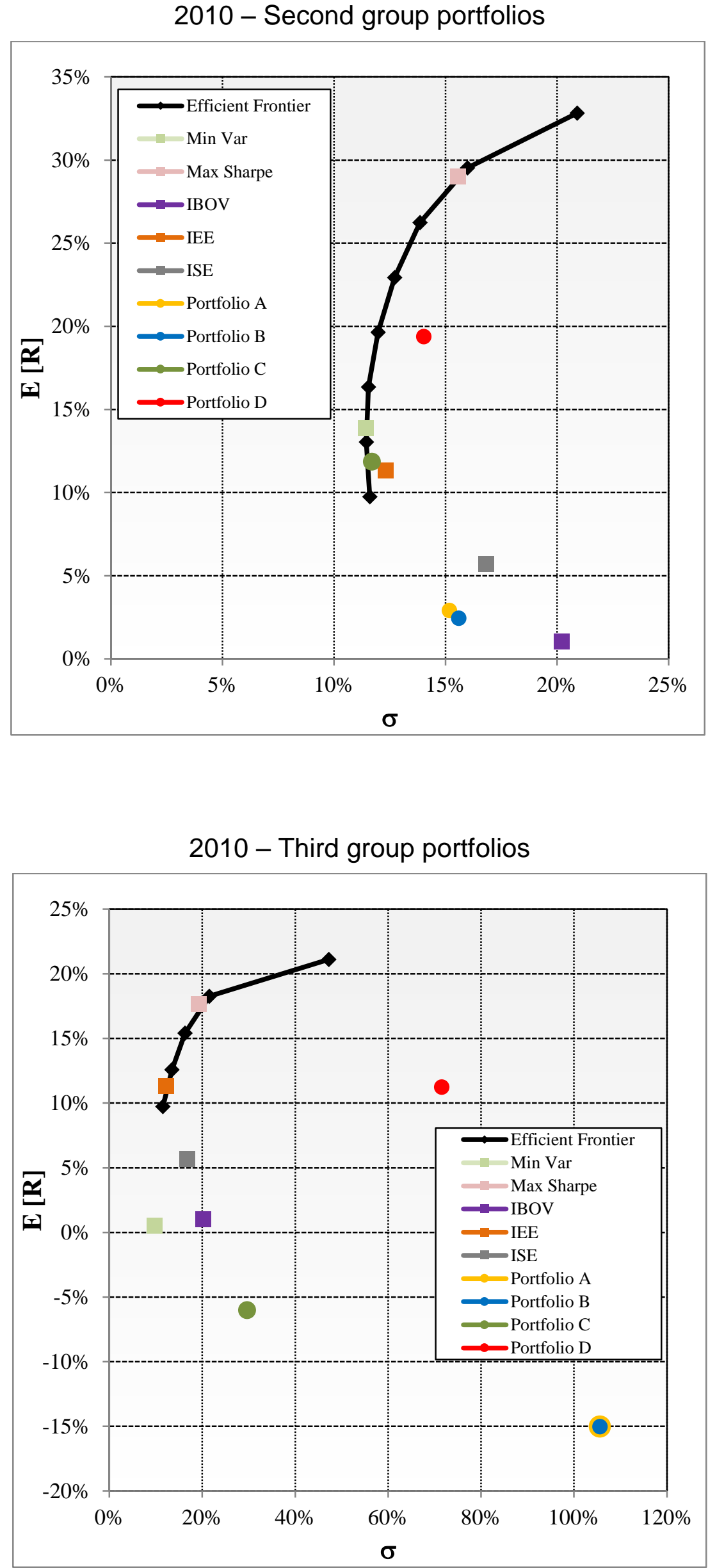
2011 - First group portfolios

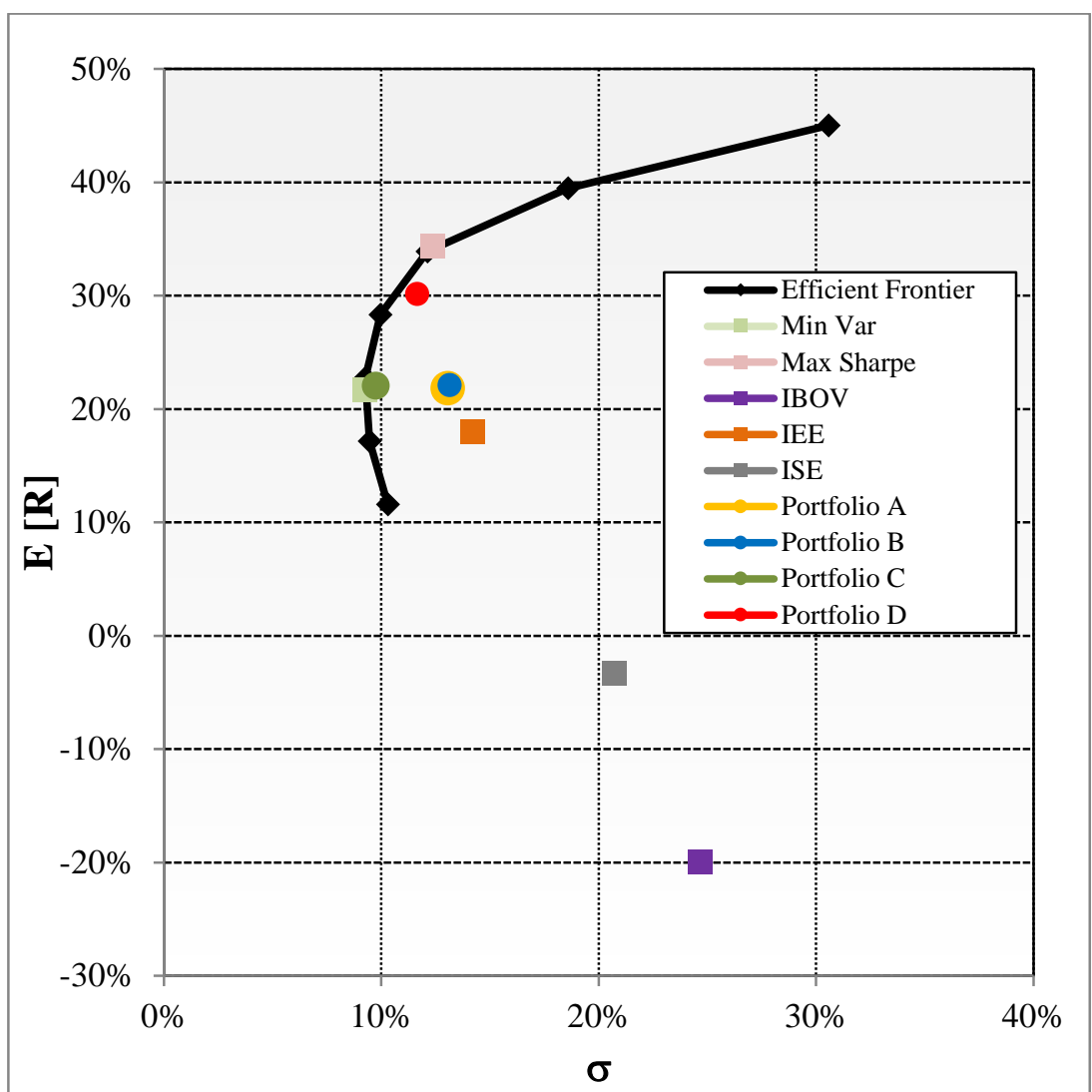

\section{1 - Second group portfolios}

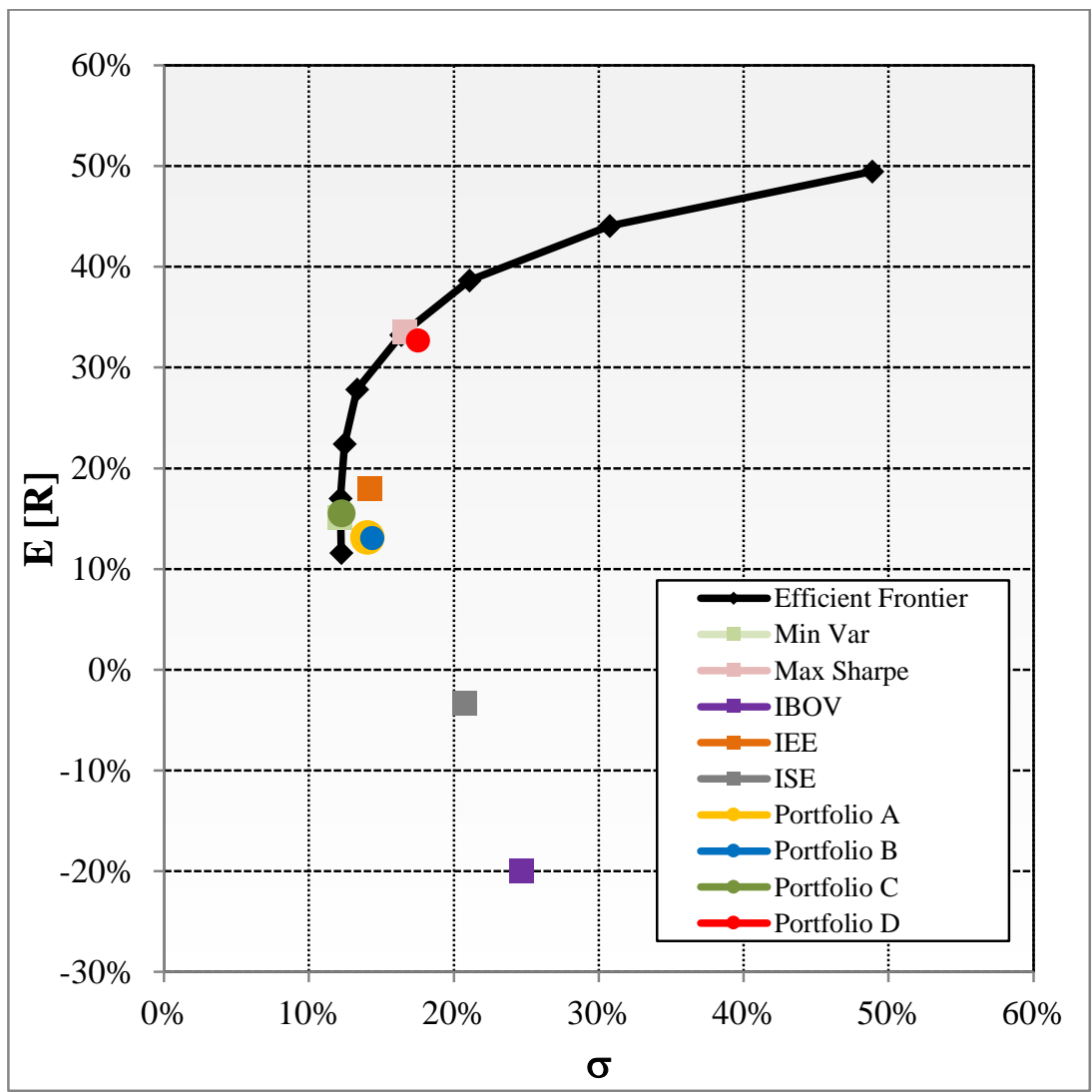



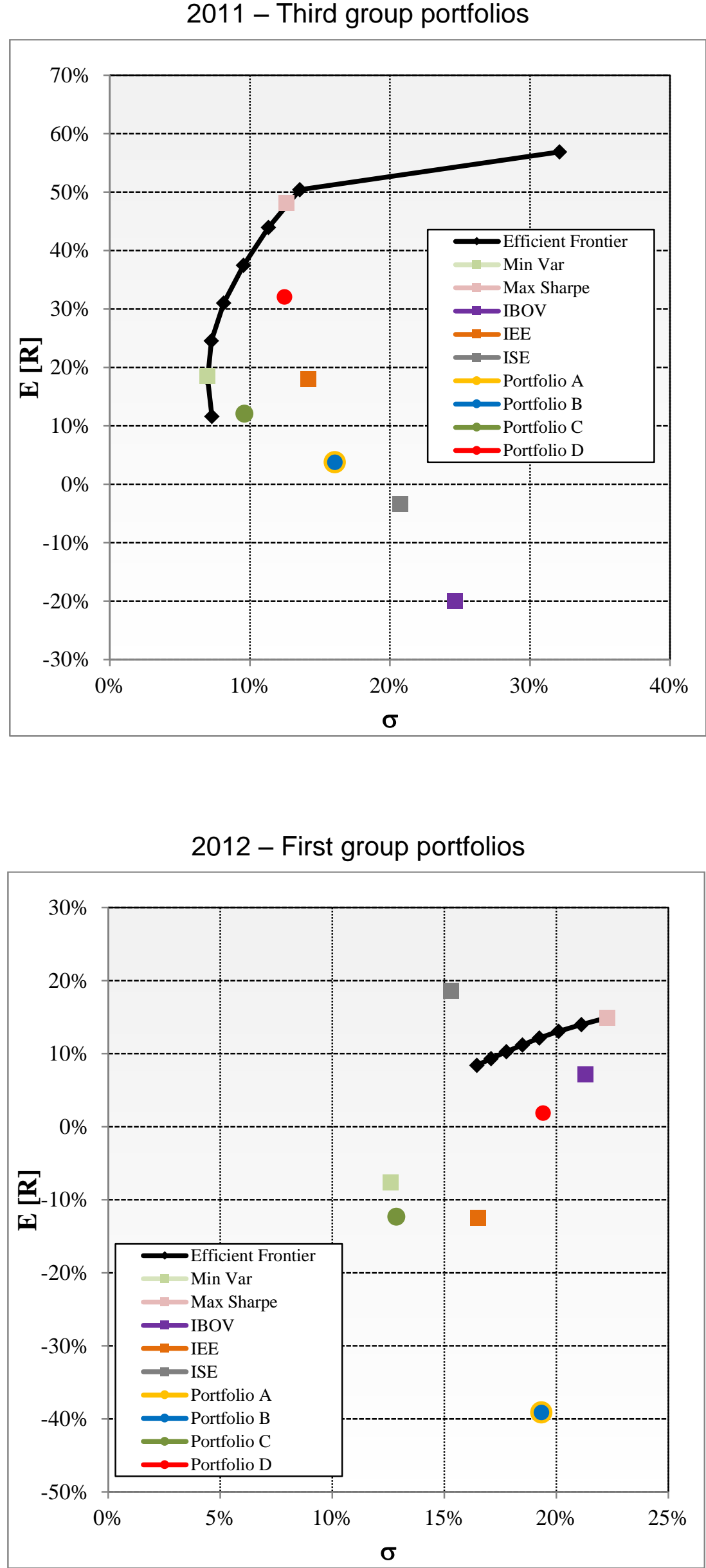

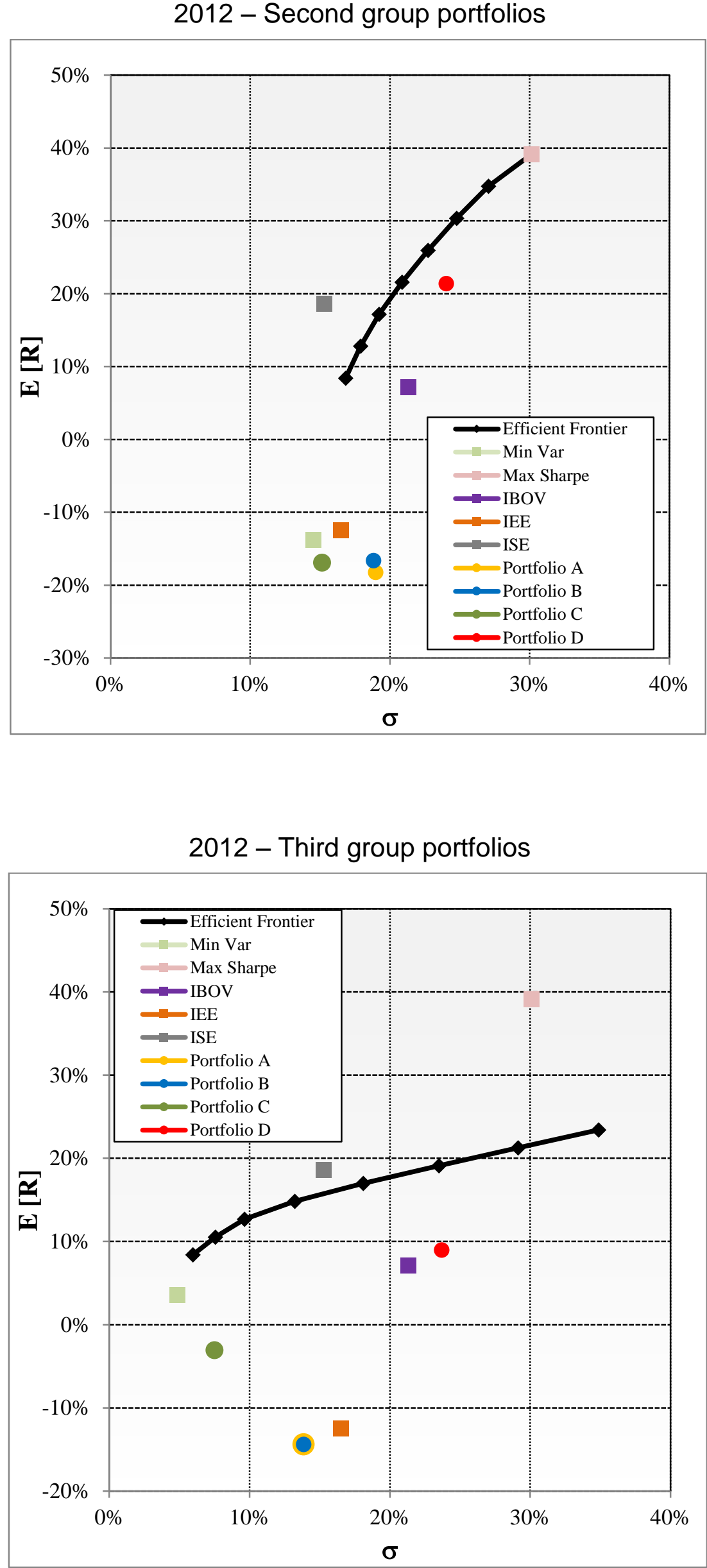


\section{Appendix G - Ex-post portfolios - Return probability distribution and sensitivity of Omega measure in relation to the minimum expected return}

IBOVESPA return probability distribution

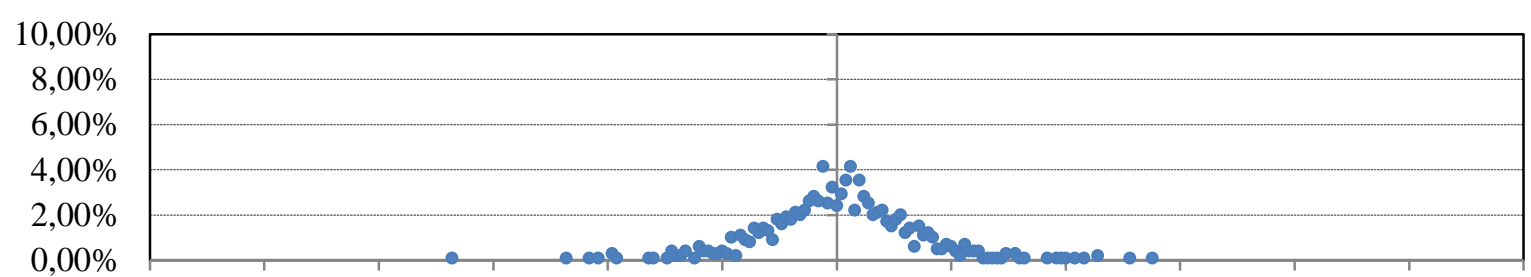

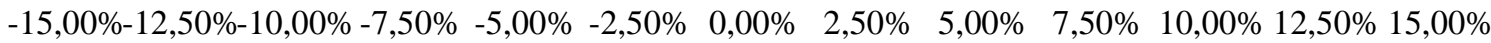

IEE return probability distribution

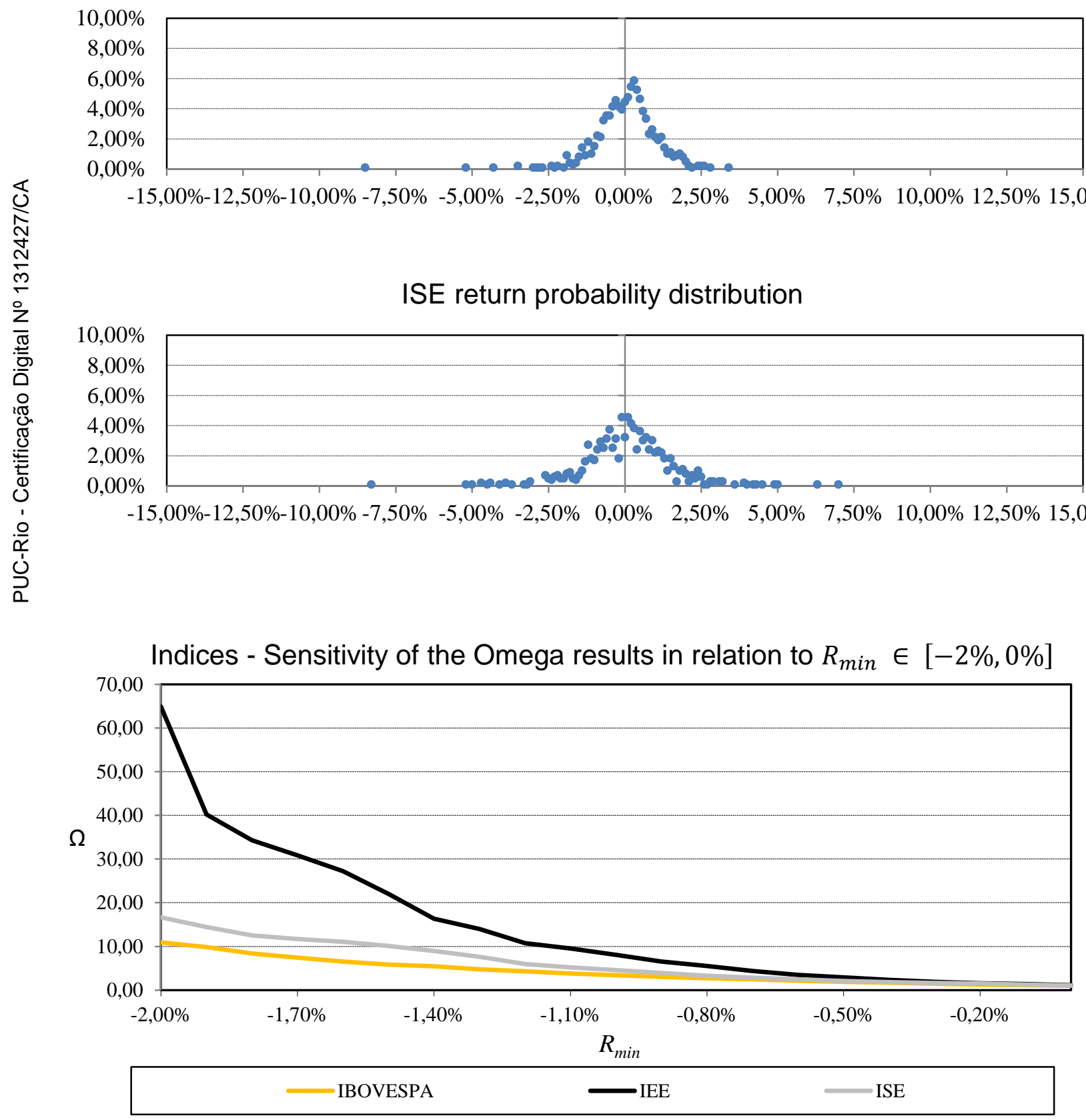


Indices - Sensitivity of the Omega results in relation to $R_{\min } \in[0 \%,+2 \%]$

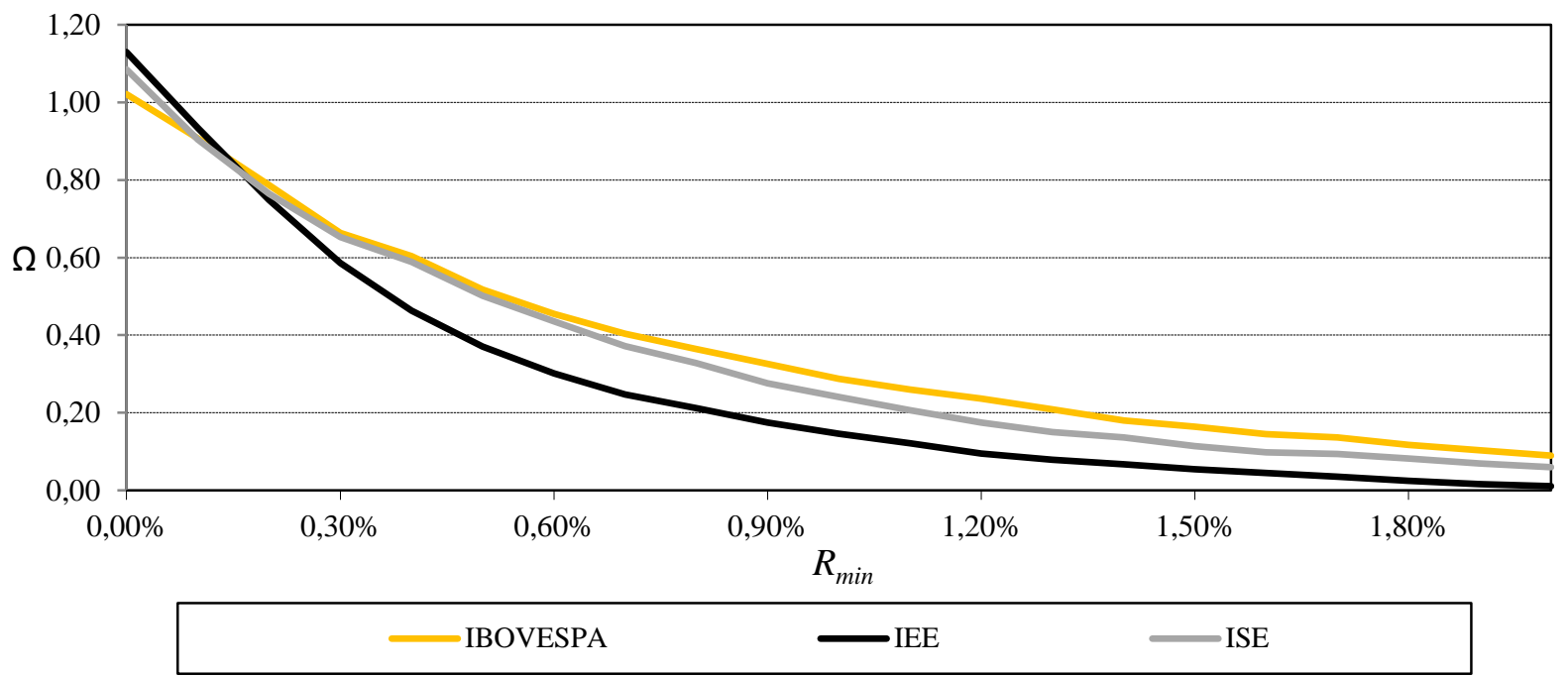

First group - Portfolio A - return probability distribution

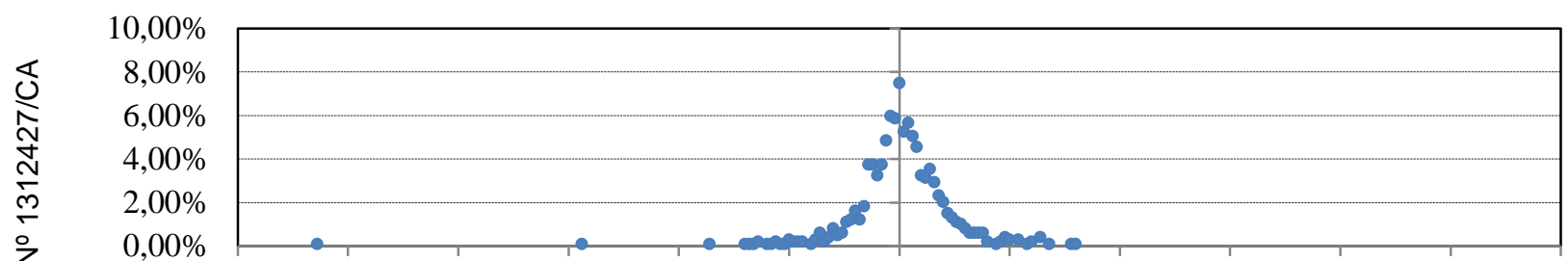

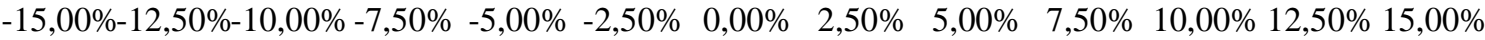

Second group - Portfolio A - return probability distribution

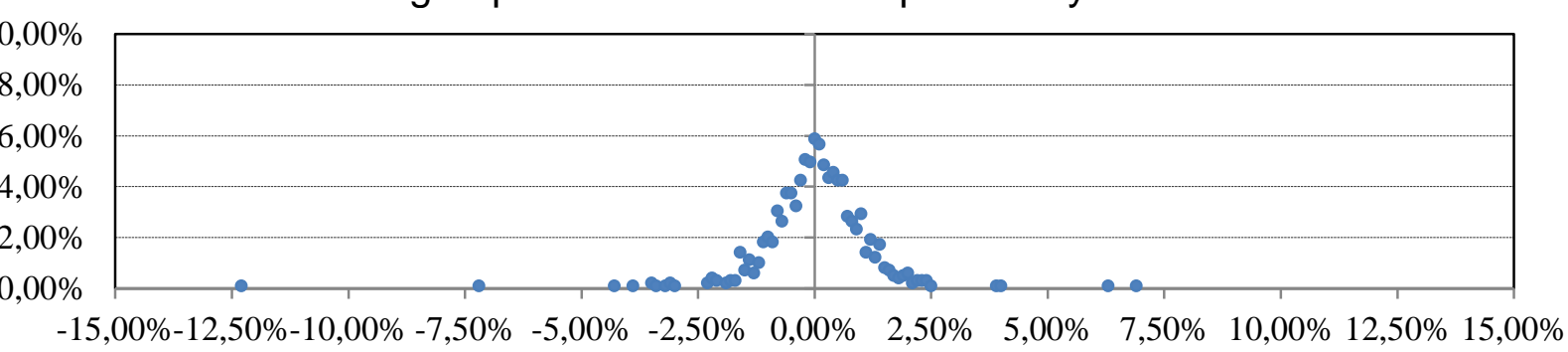

Third group - Portfolio A - return probability distribution

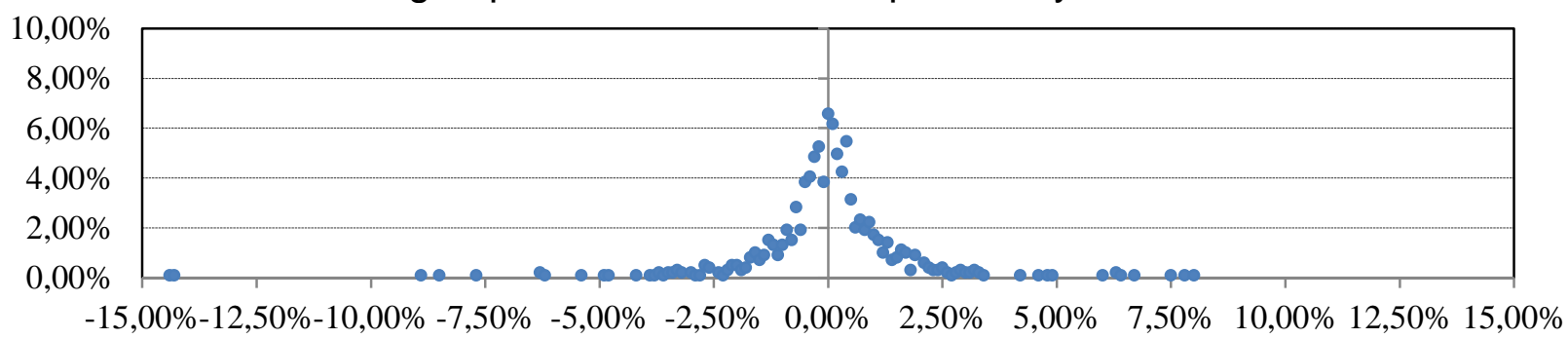


Portfolios A - Sensitivity of the Omega results in relation to $R_{\min } \in[-2 \%, 0 \%]$

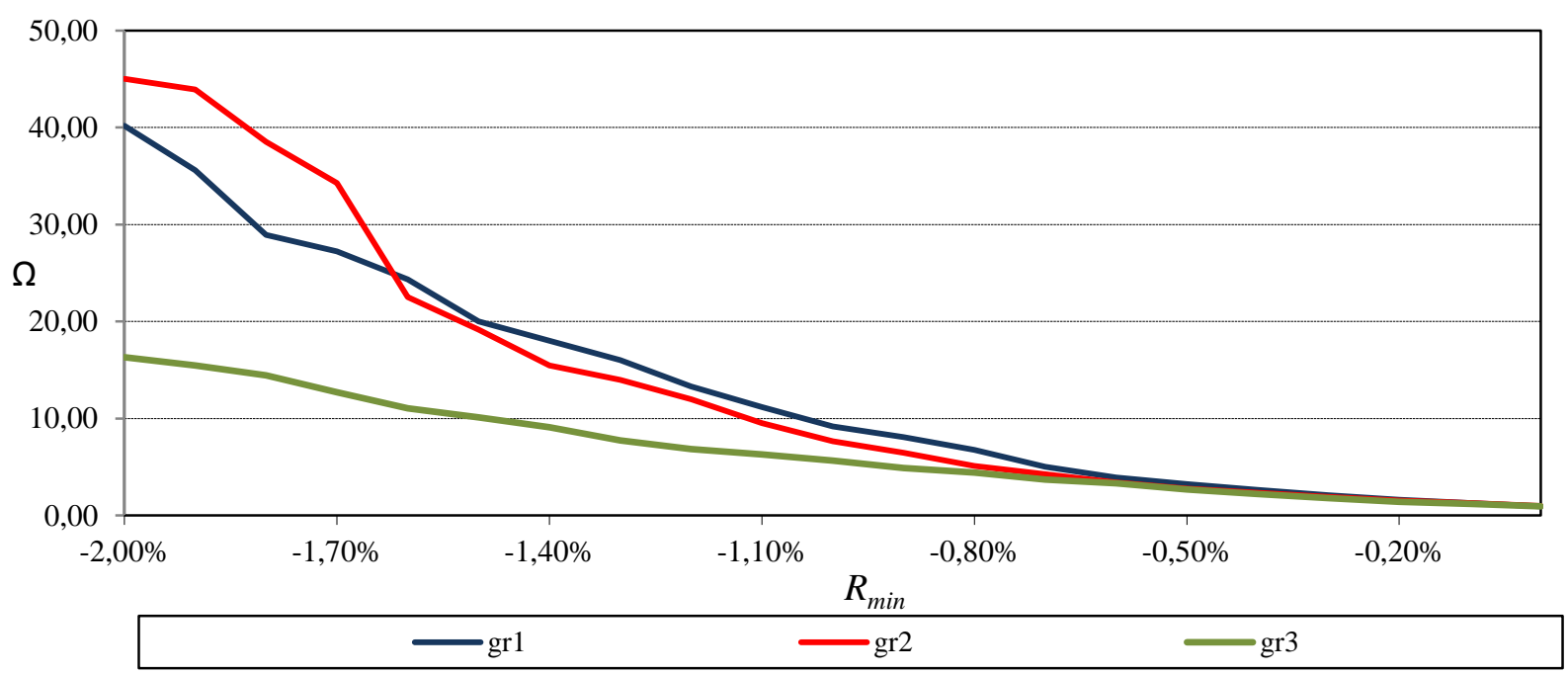

Portfolios A - Sensitivity of the Omega results in relation to $R_{\min } \in[0 \%,+2 \%]$

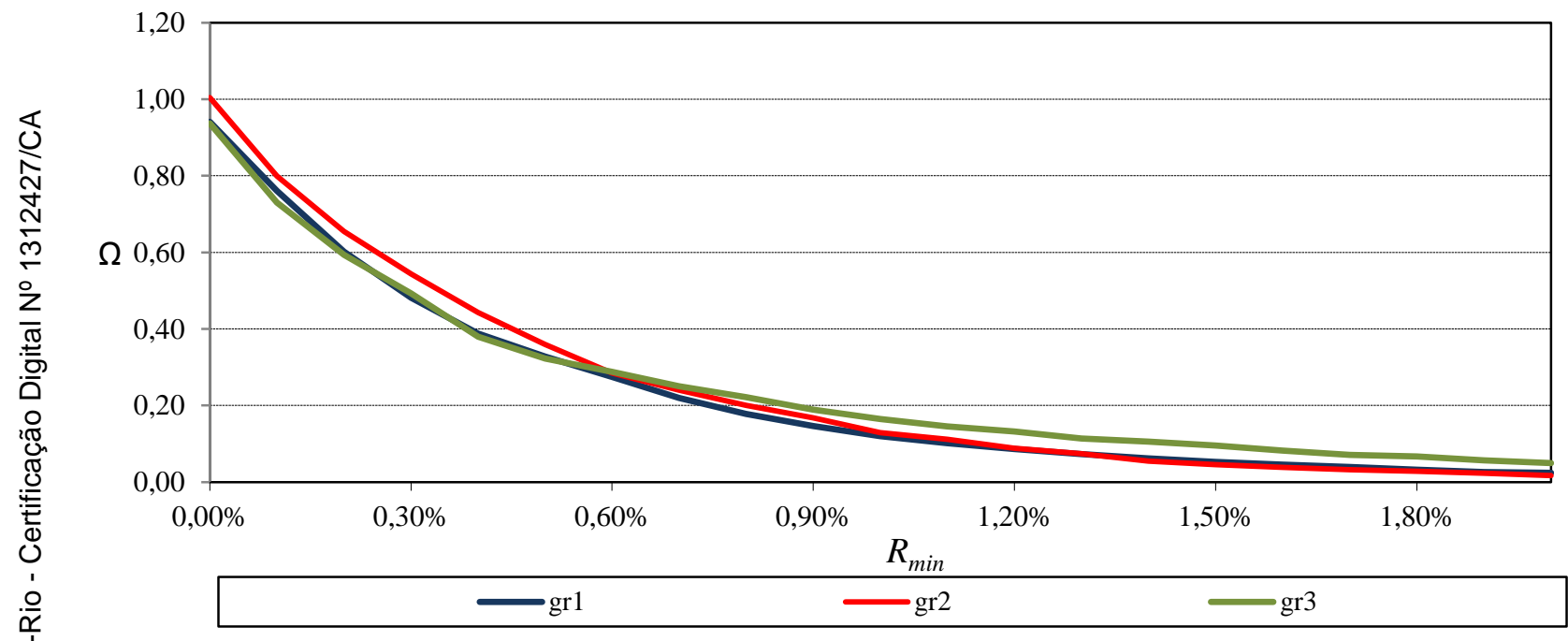

First group - Portfolio B - return probability distribution
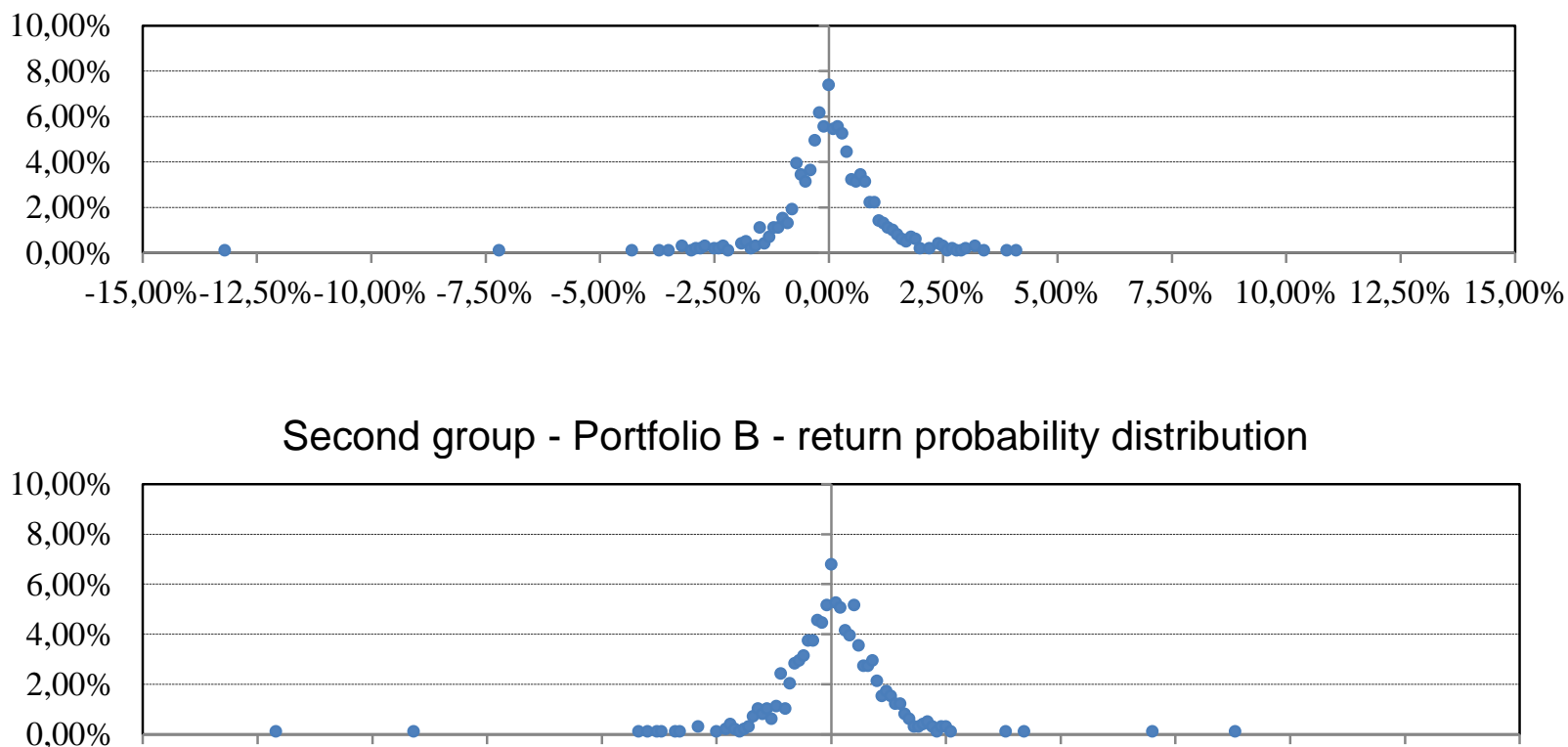

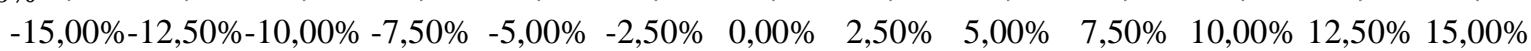


Third group - Portfolio B - return probability distribution

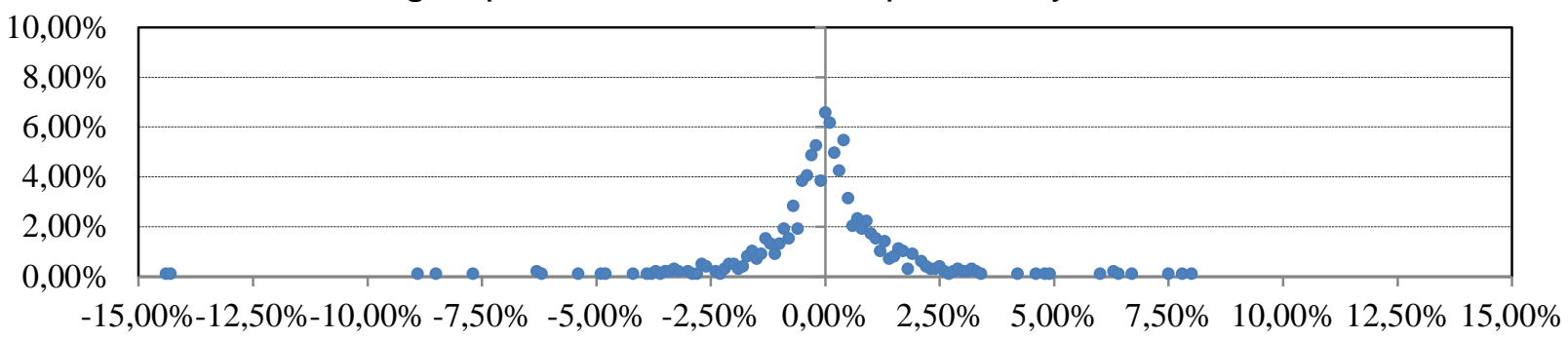

Portfolios B - Sensitivity of the Omega results in relation to $R_{\min } \in[-2 \%, 0 \%]$

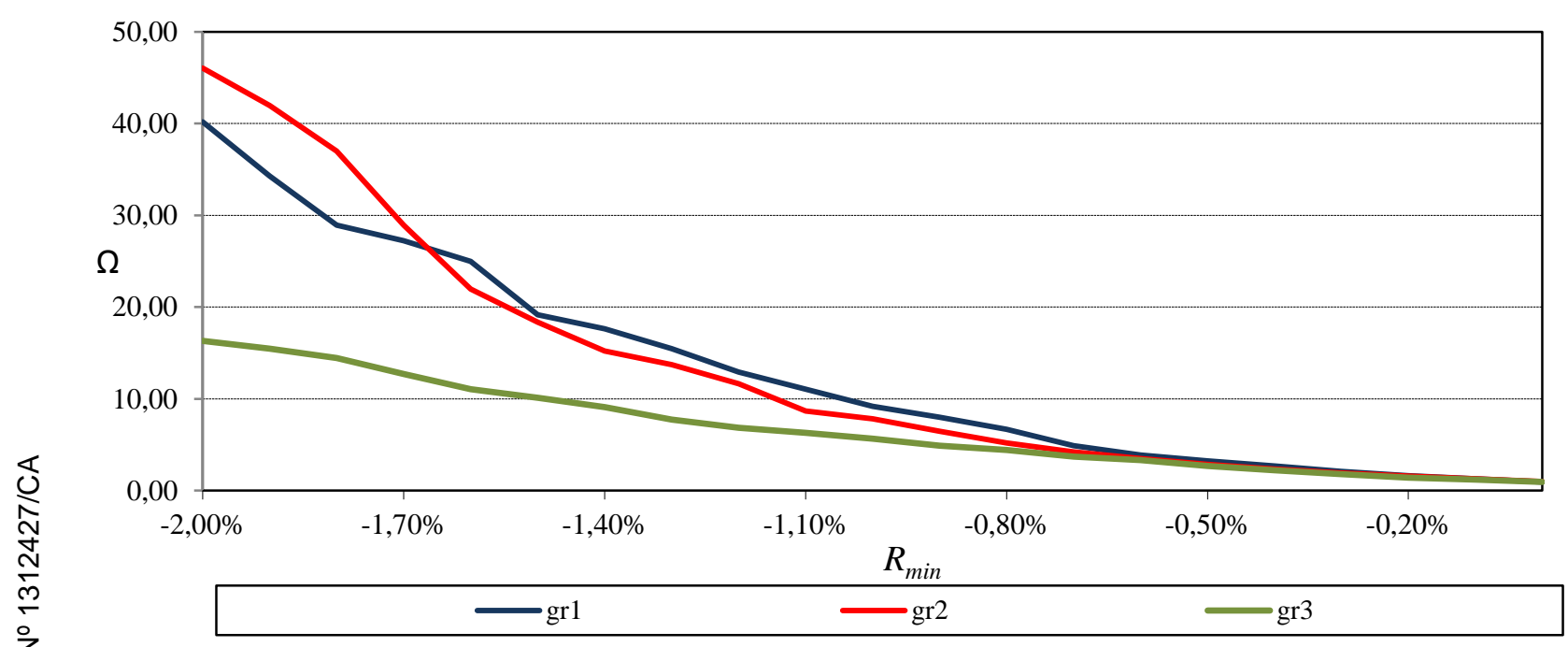

Portfolios A - Sensitivity of the Omega results in relation to $R_{\min } \in[0 \%,+2 \%]$

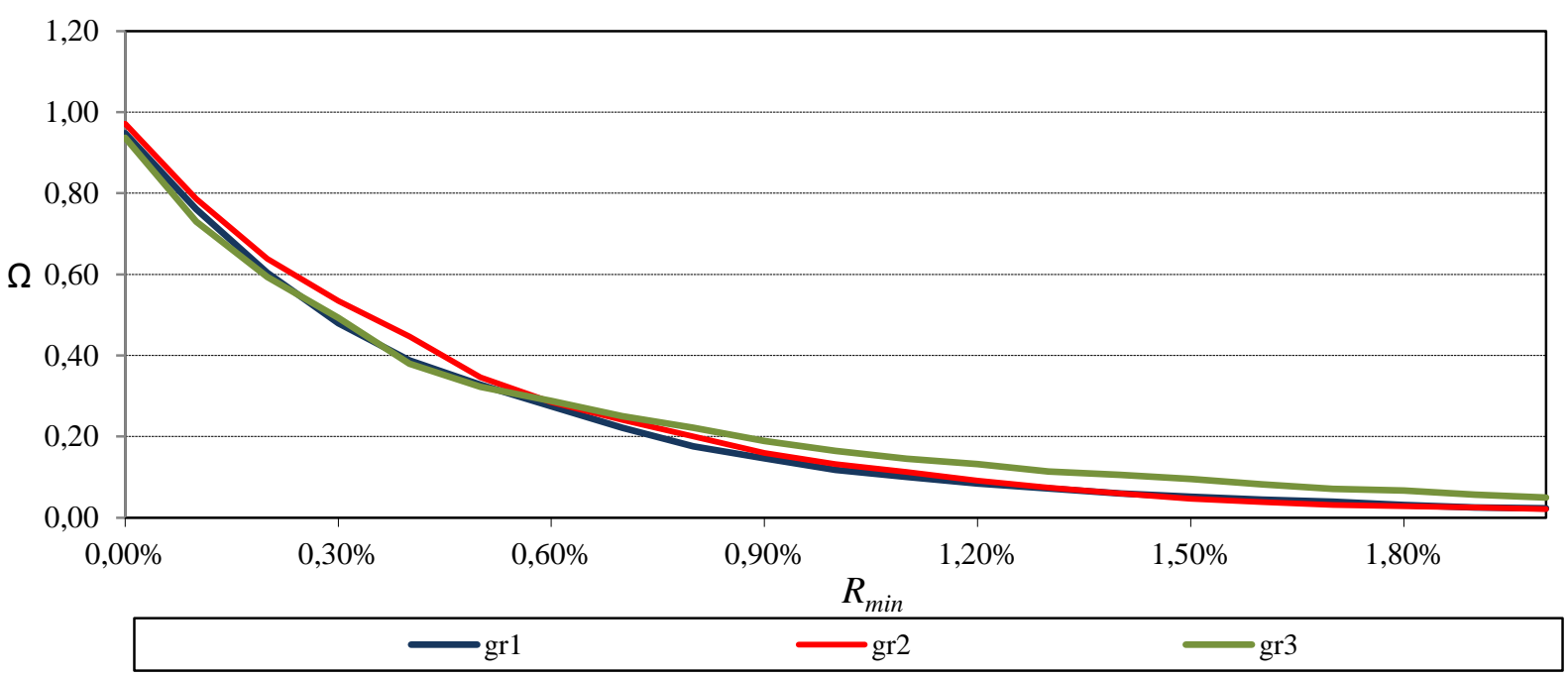

First group - Portfolio C - return probability distribution

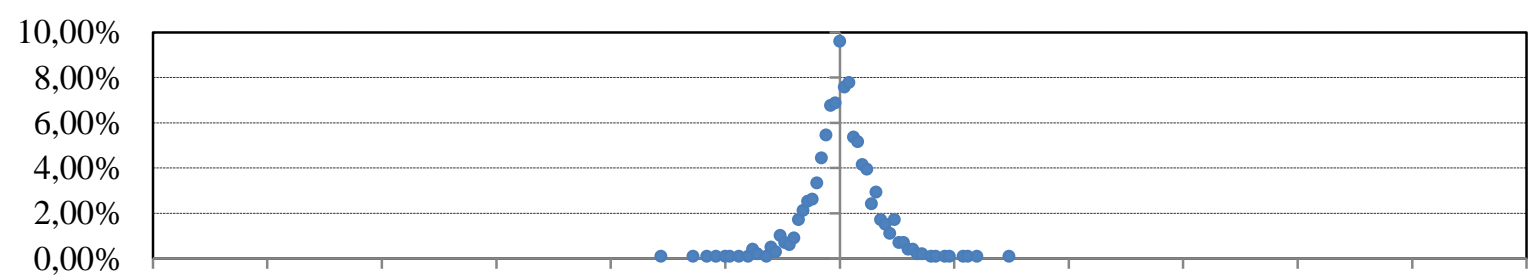

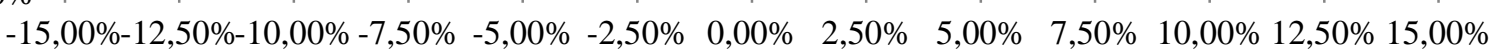




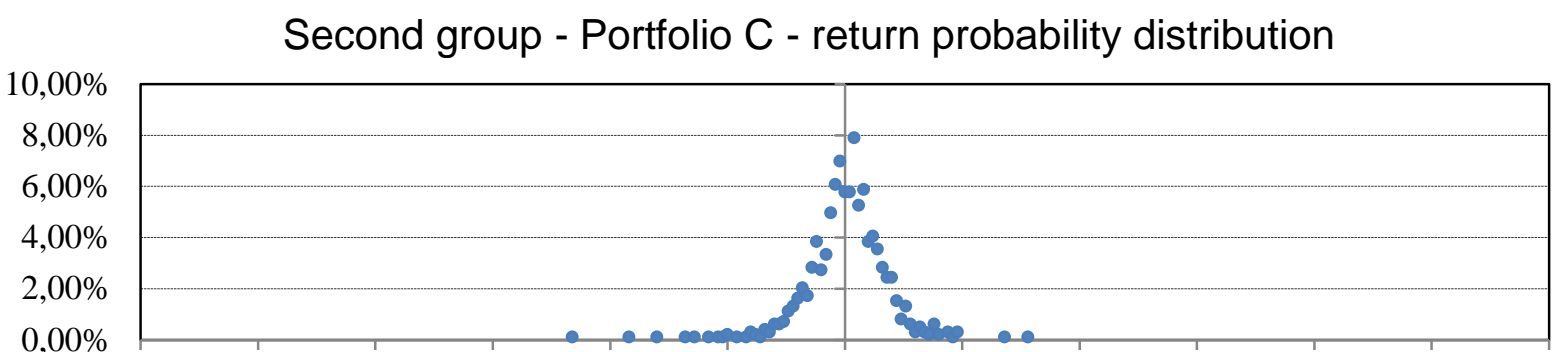

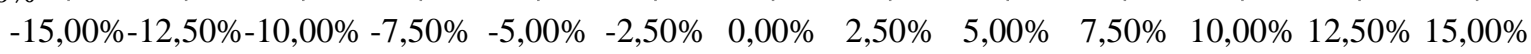

Third group - Portfolio C - return probability distribution

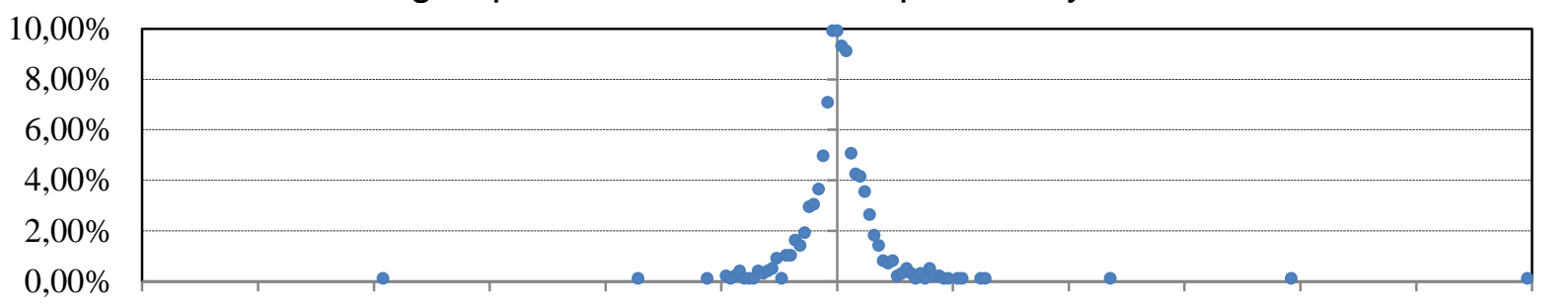

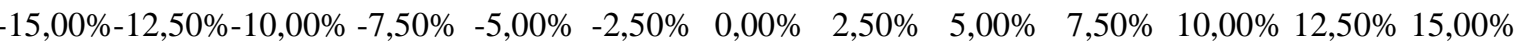

Portfolios C - Sensitivity of the Omega results in relation to $R_{\min } \in[-2 \%, 0 \%]$

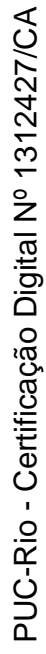

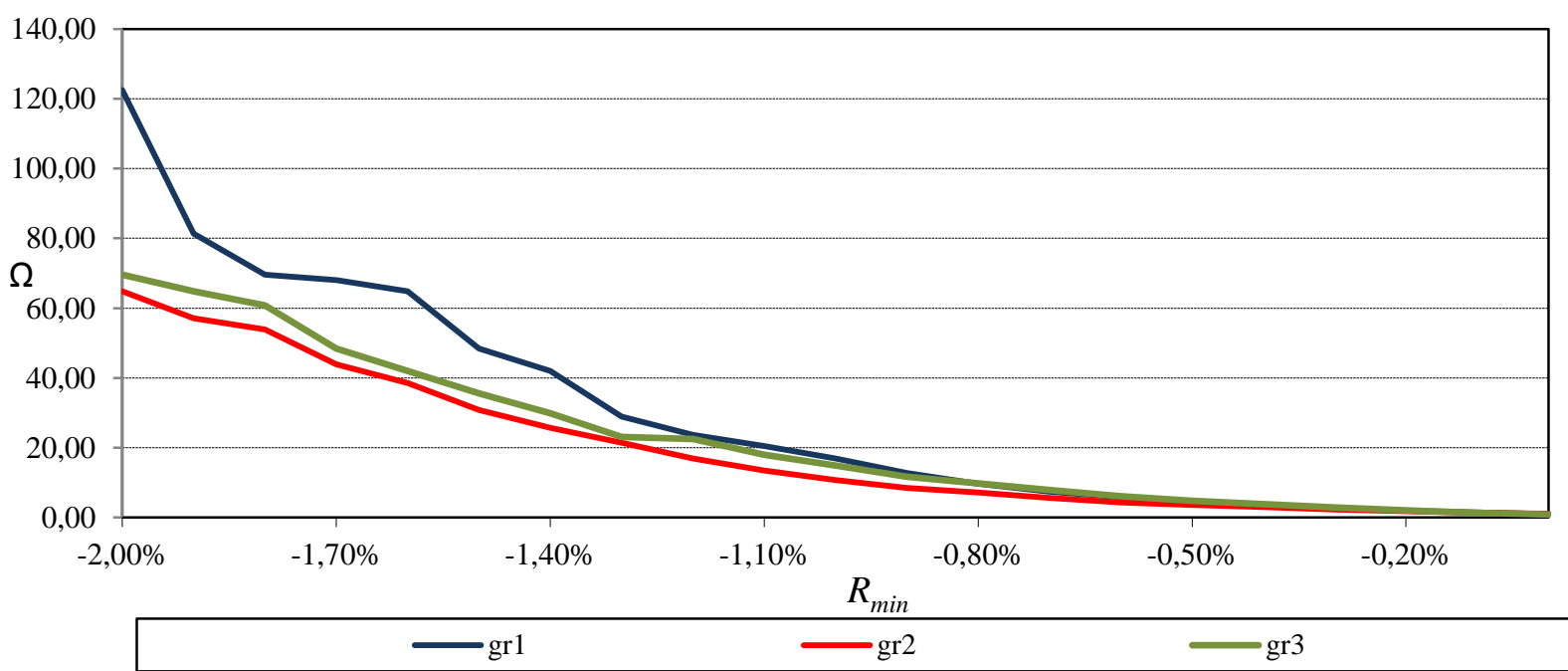

Portfolios C - Sensitivity of the Omega results in relation to $R_{\min } \in[0 \%,+2 \%]$

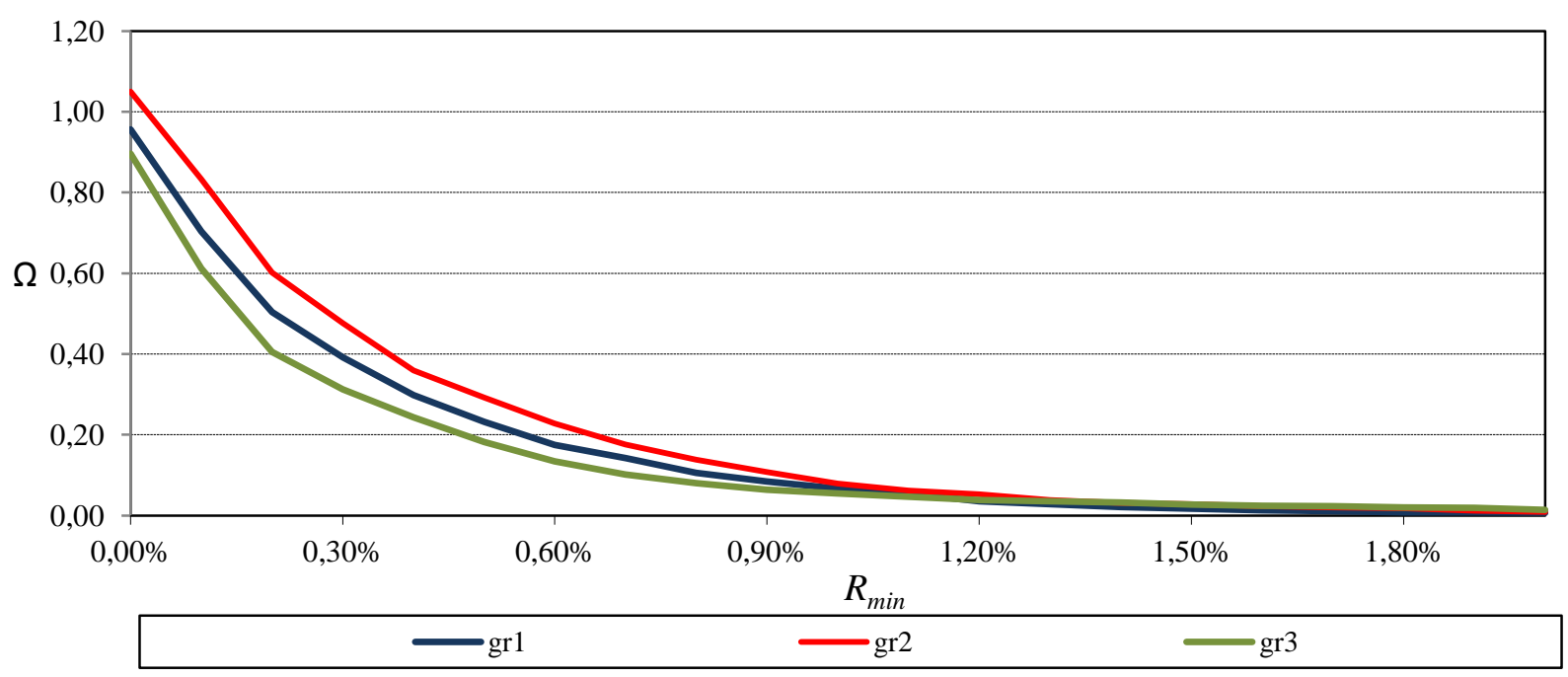


First group - Portfolio D - return probability distribution

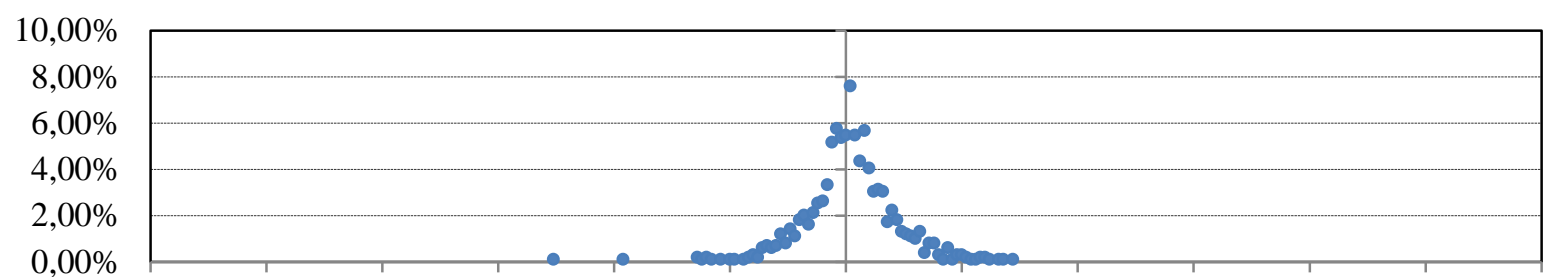

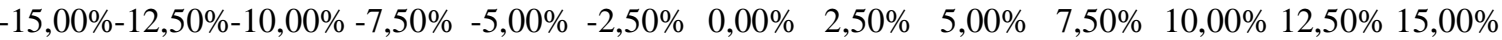

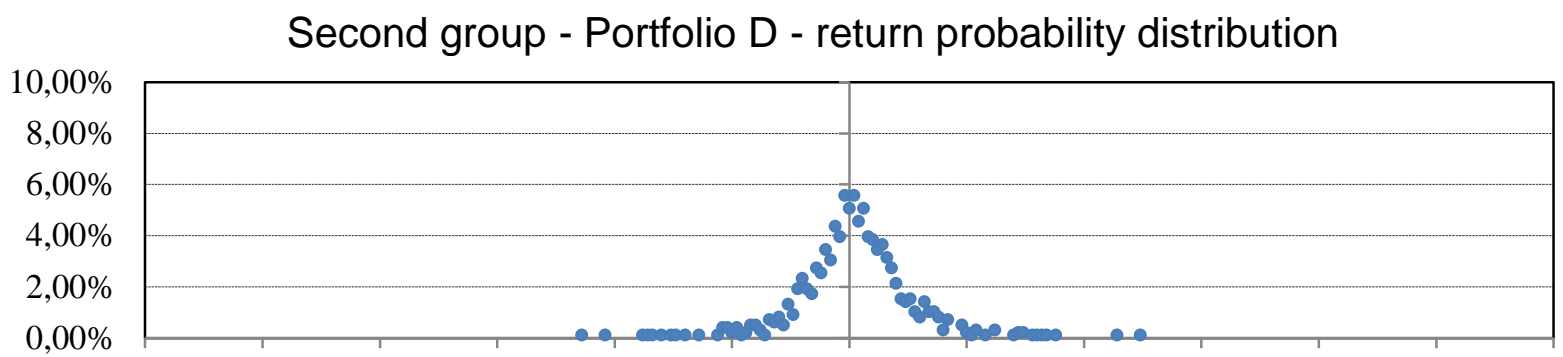

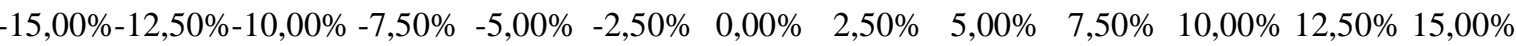

Third group - Portfolio D - return probability distribution

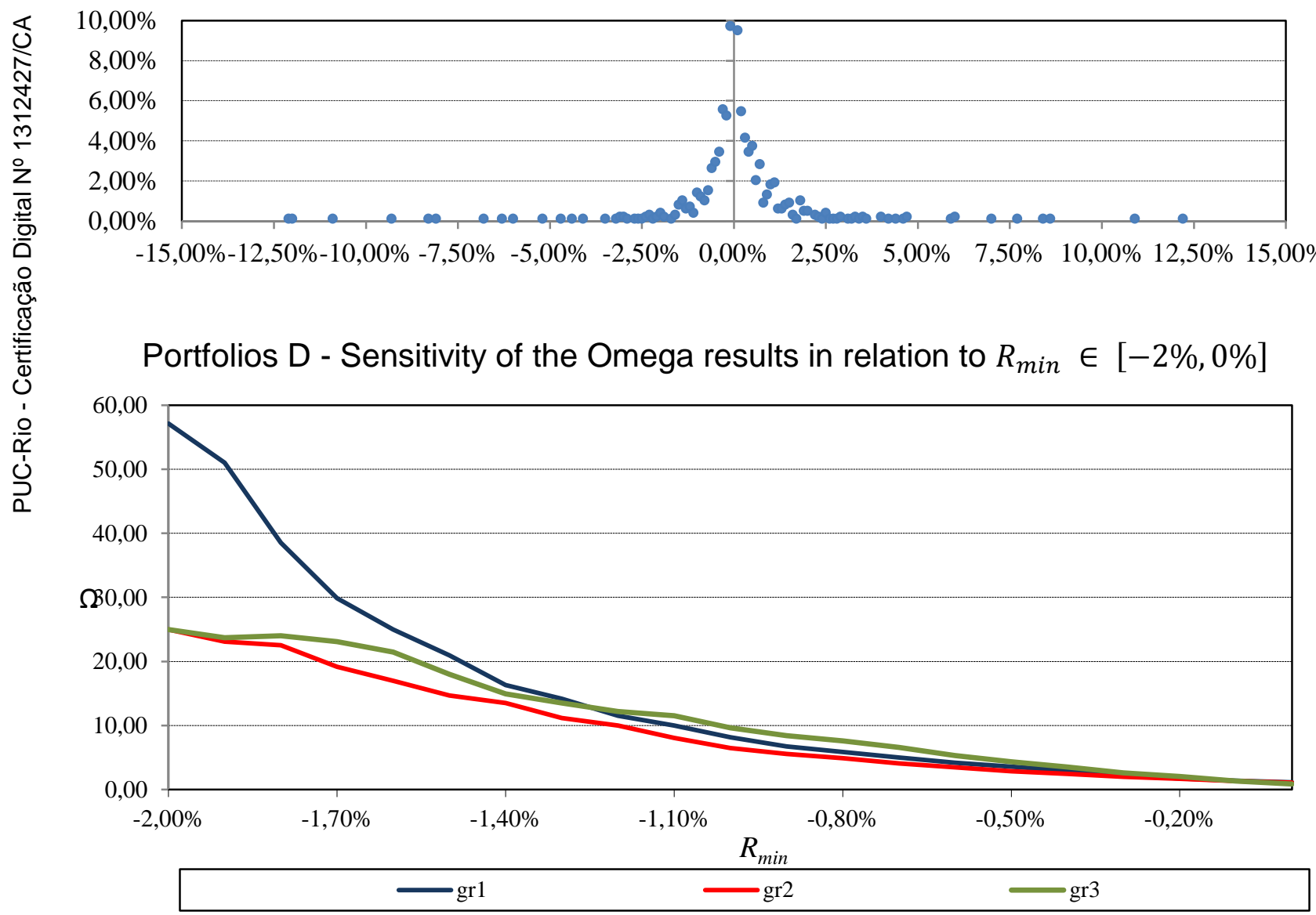


Portfolios D - Sensitivity of the Omega results in relation to $R_{\min } \in[0 \%,+2 \%]$

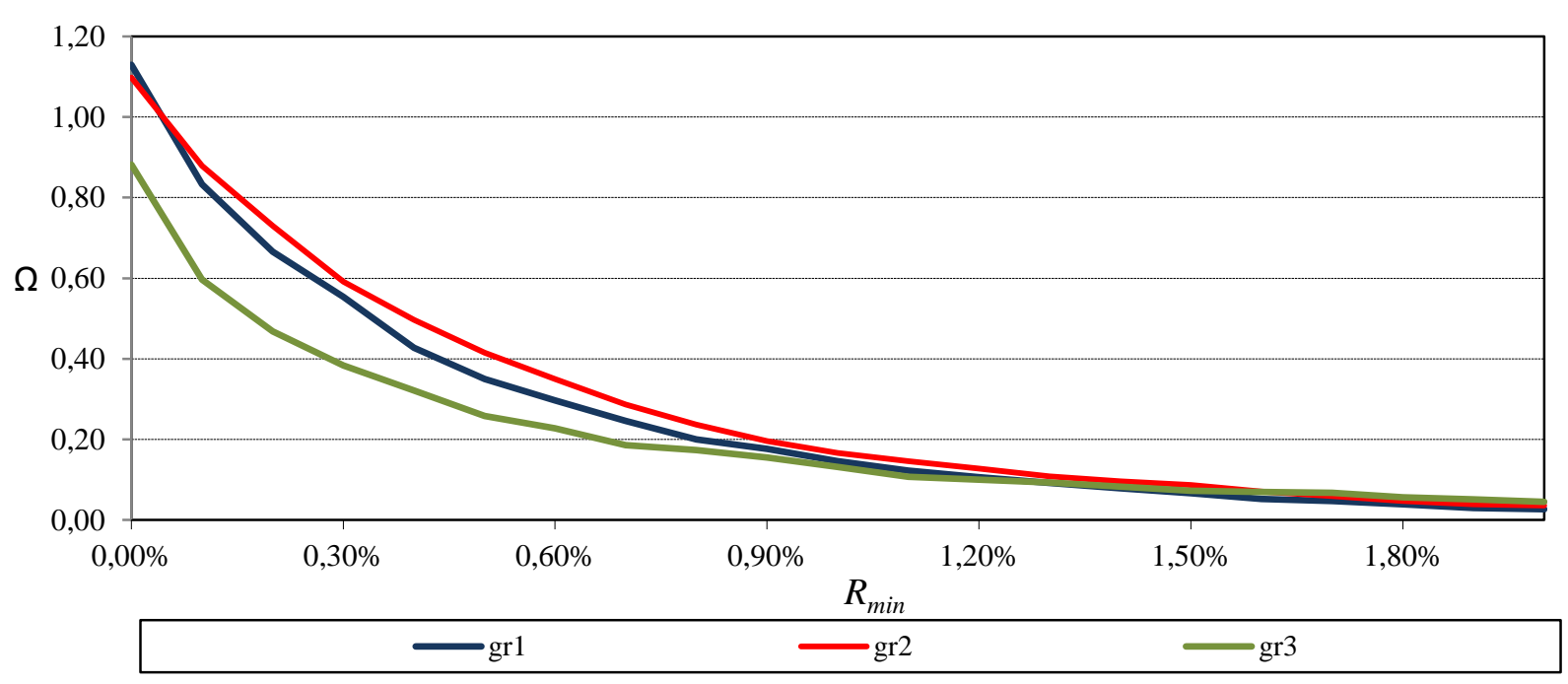

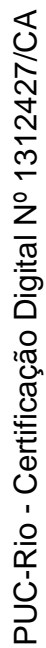




\section{Appendix $\mathrm{H}$ - Ex-ante portfolios - Sensitivity of Omega measure results in relation to the minimum expected return}

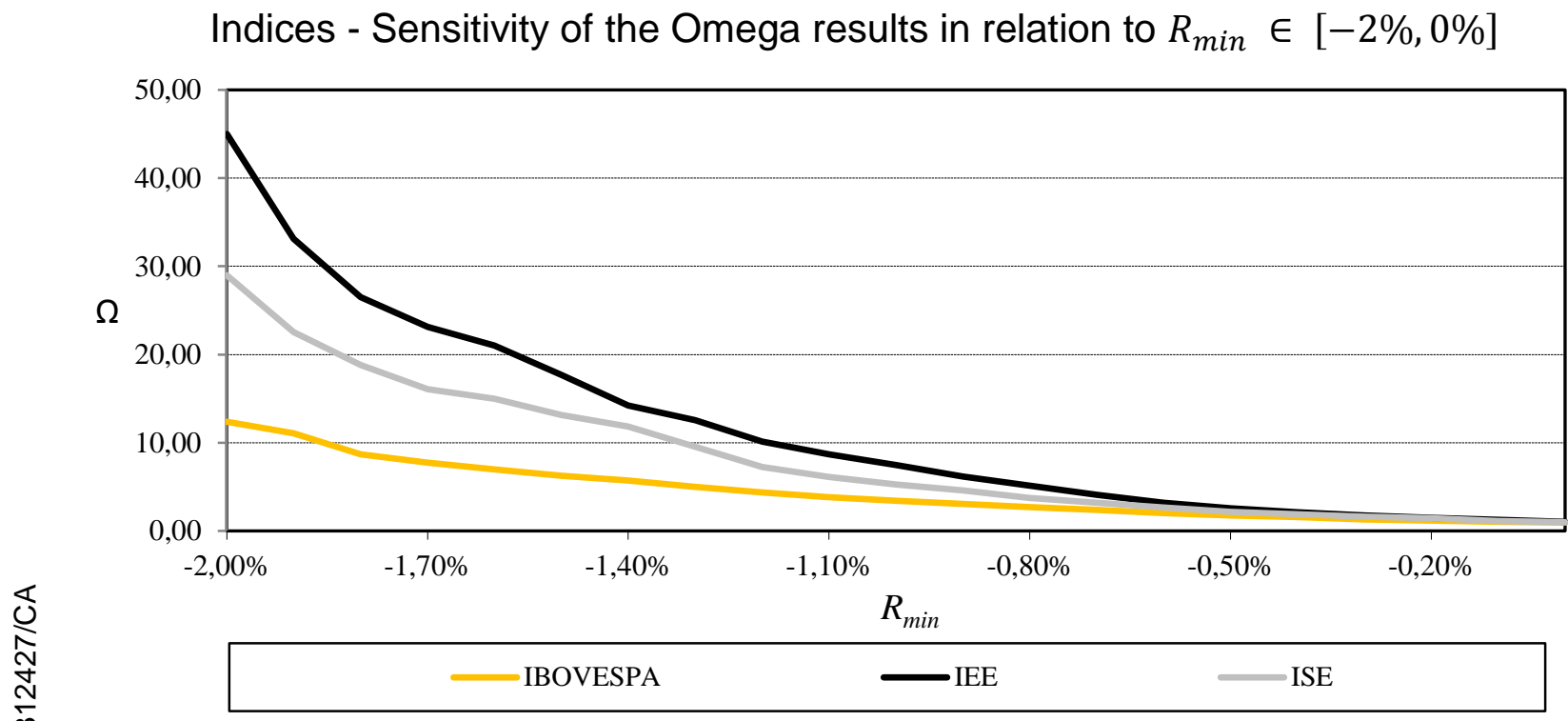

Indices - Sensitivity of the Omega results in relation to $R_{\min } \in[0 \%,+2 \%]$

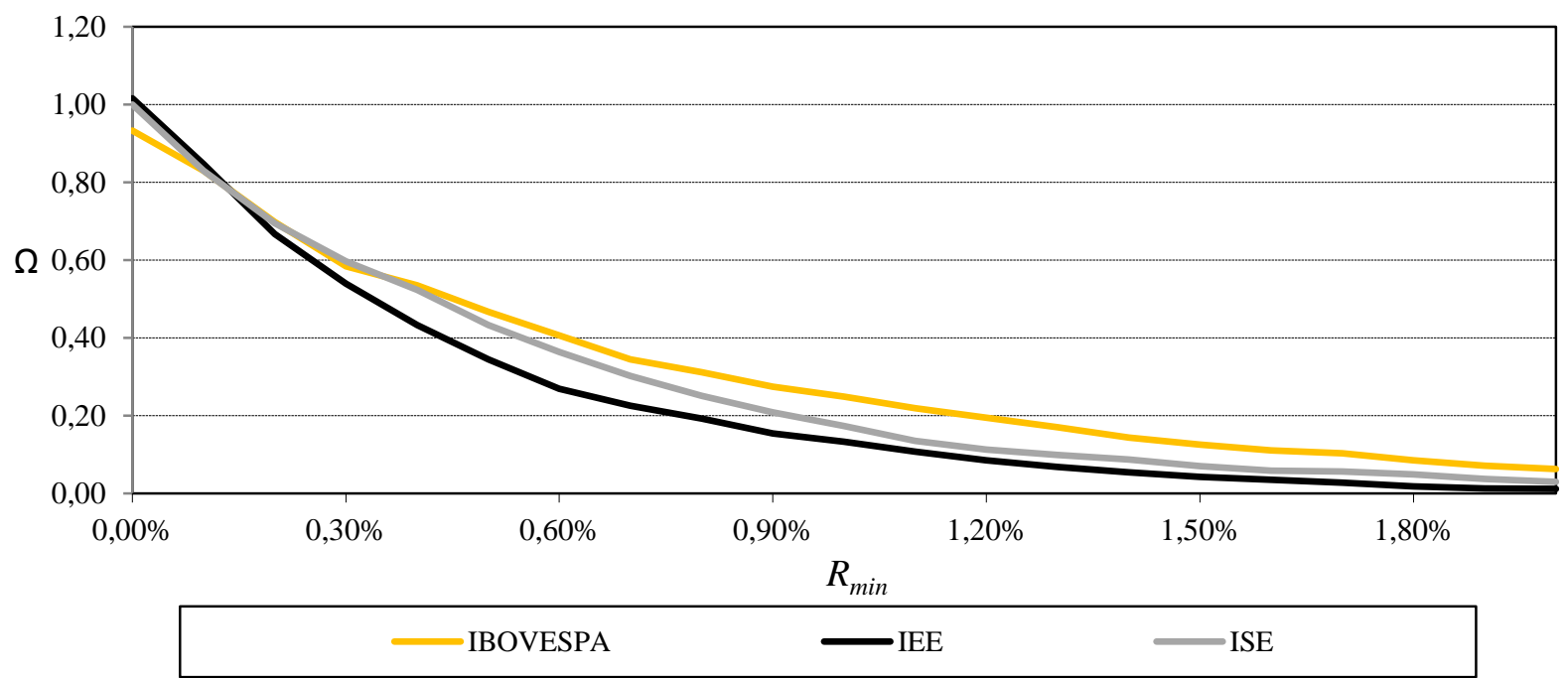


Portfolios A - Sensitivity of the Omega results in relation to $R_{\min } \in[-2 \%, 0 \%]$

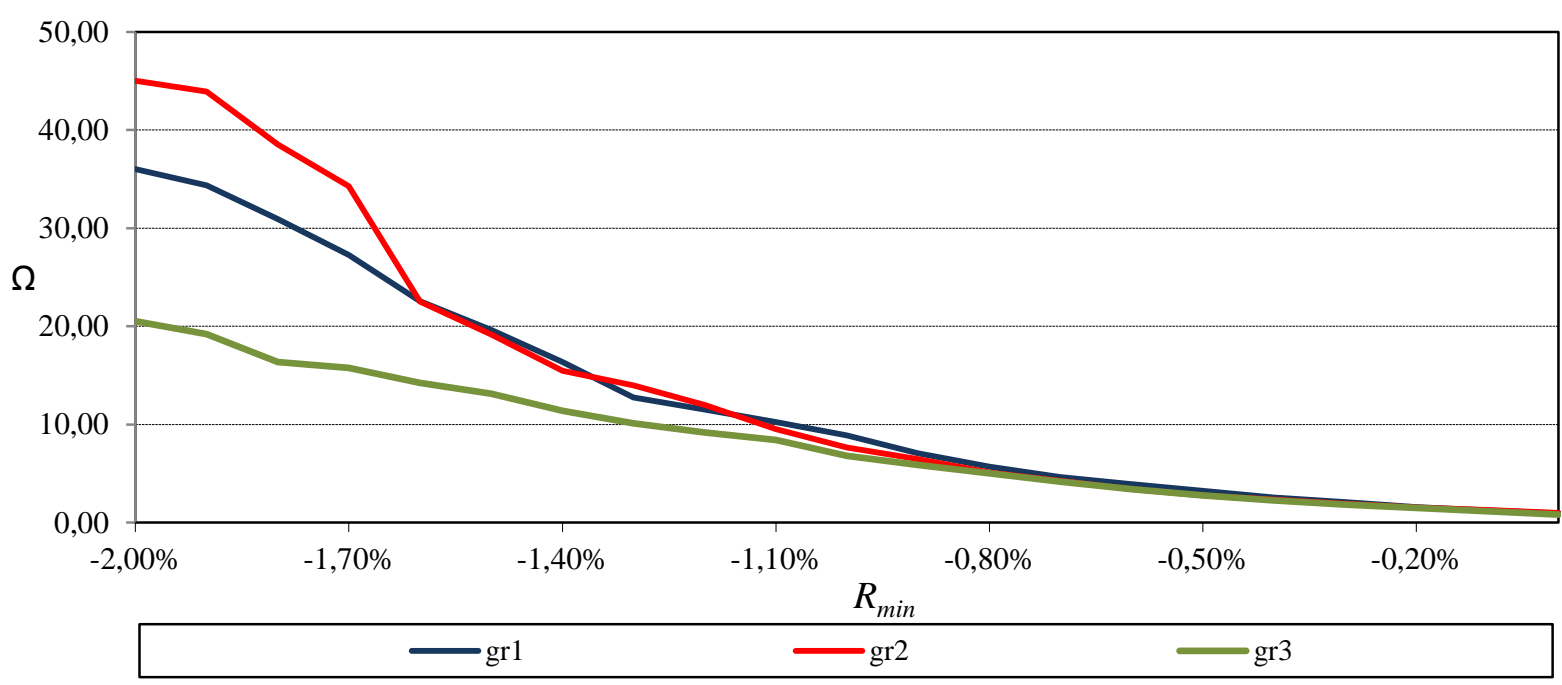

Portfolios A - Sensitivity of the Omega results in relation to $R_{\min } \in[0 \%,+2 \%]$

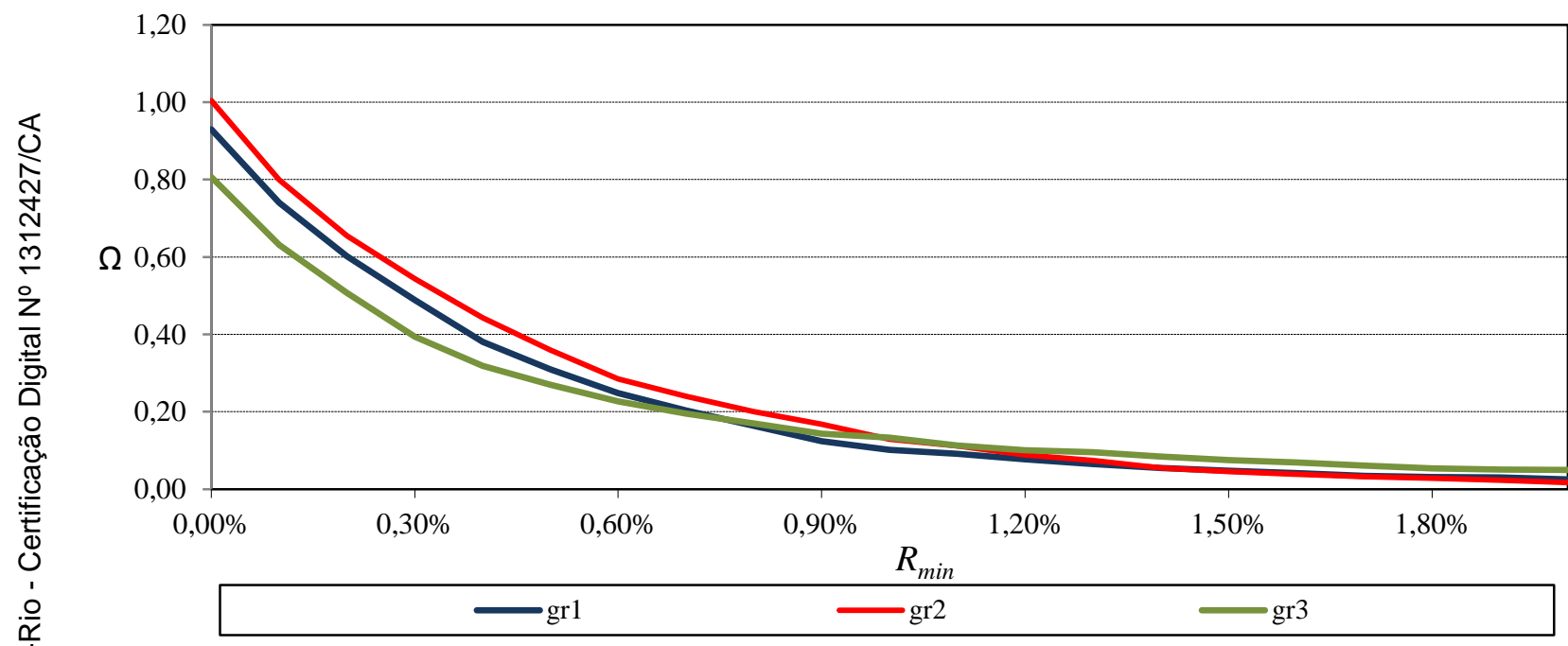

Portfolios B - Sensitivity of the Omega results in relation to $R_{\min } \in[-2 \%, 0 \%]$

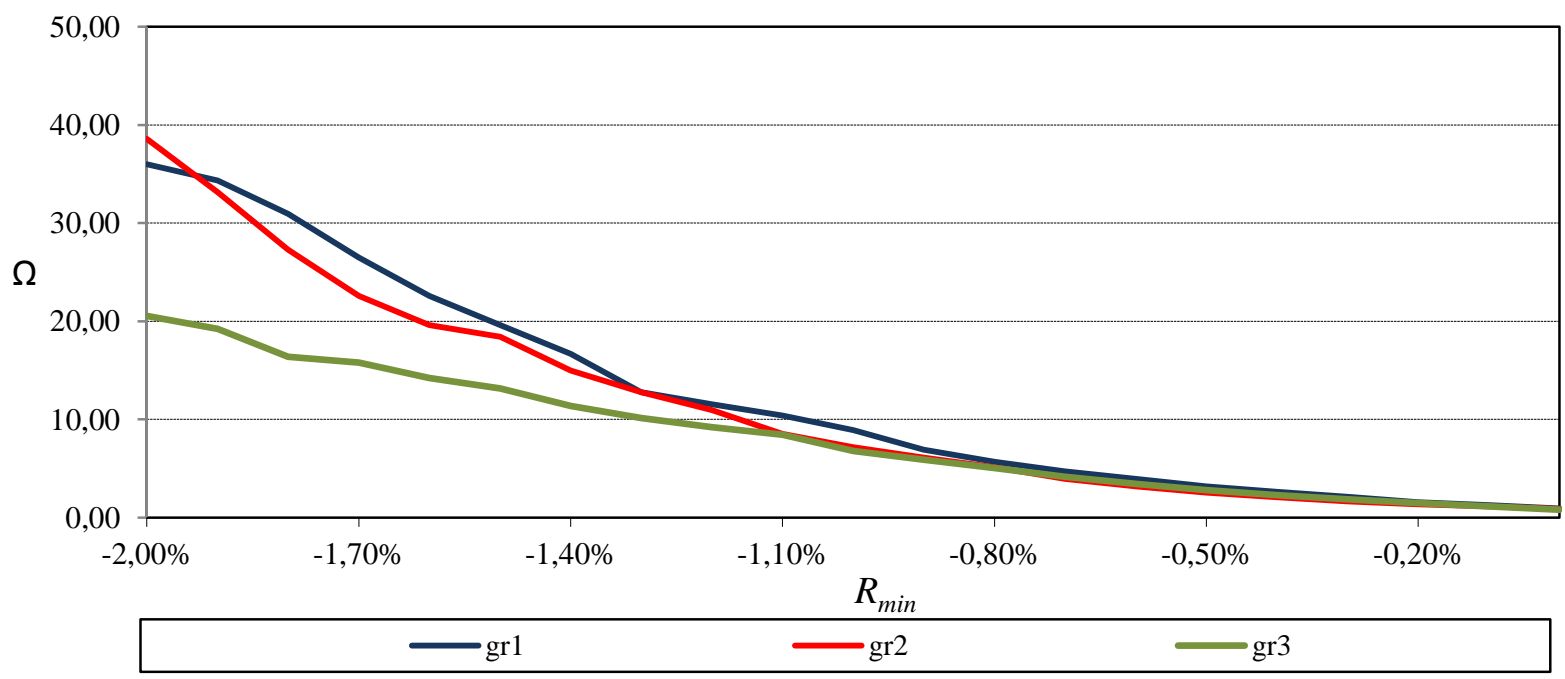


Portfolios B - Sensitivity of the Omega results in relation to $R_{\min } \in[0 \%,+2 \%]$

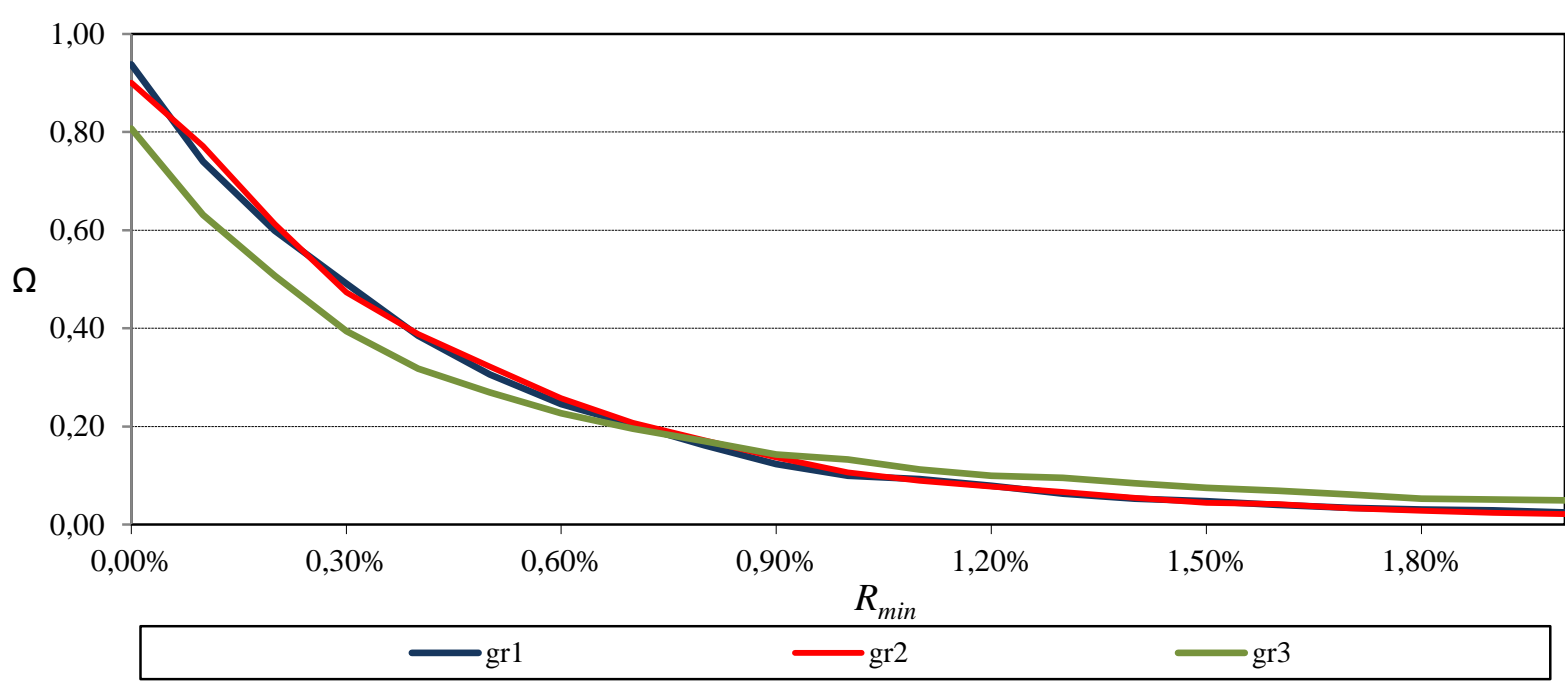

Portfolios C - Sensitivity of the Omega results in relation to $R_{\min } \in[-2 \%, 0 \%]$

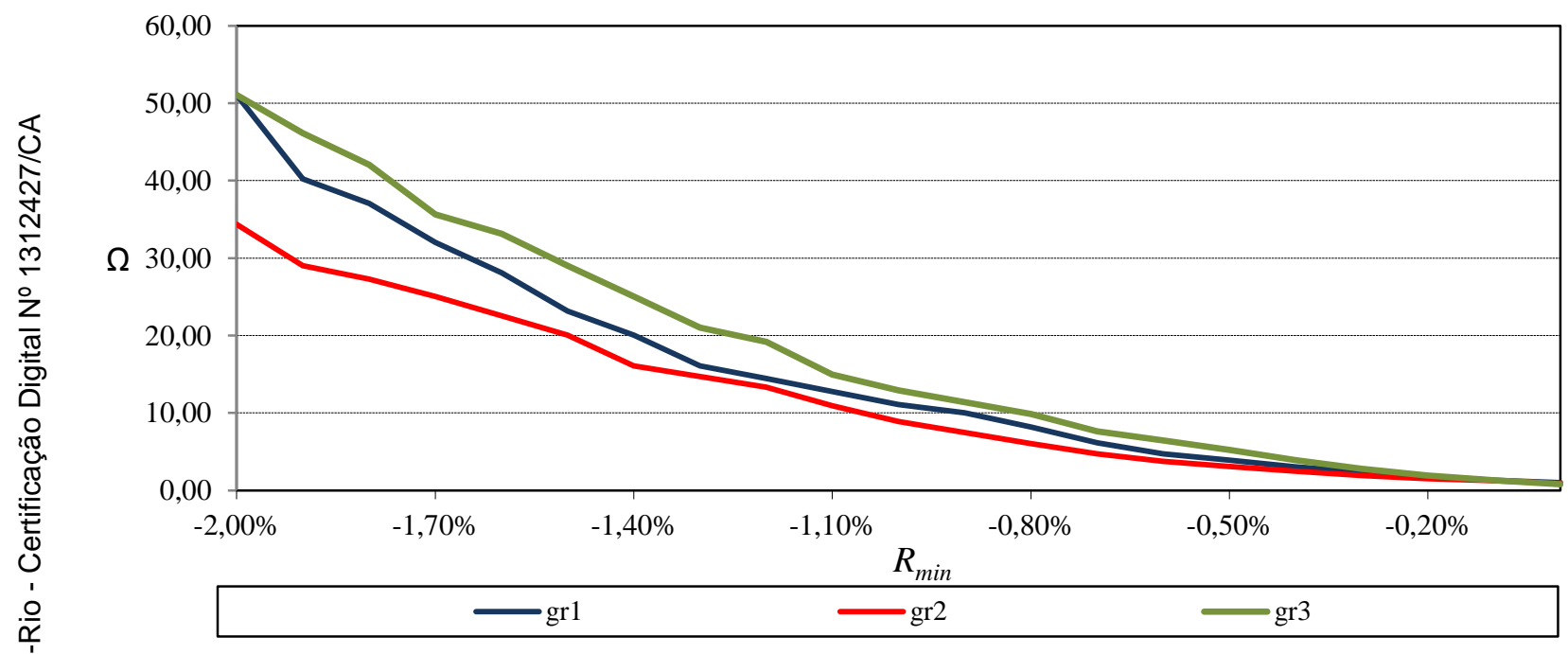

Portfolios C - Sensitivity of the Omega results in relation to $R_{\min } \in[0 \%,+2 \%]$

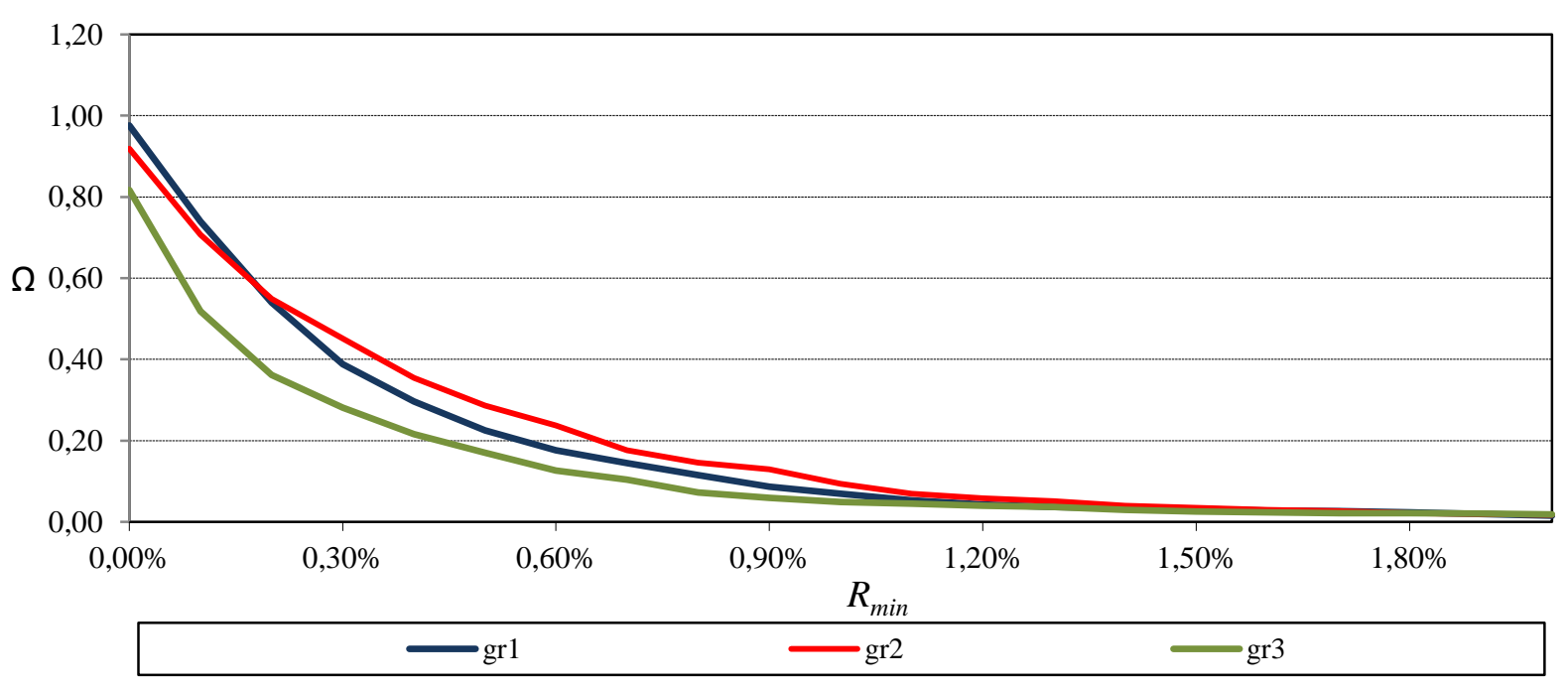


Portfolios D - Sensitivity of the Omega results in relation to $R_{\min } \in[-2 \%, 0 \%]$

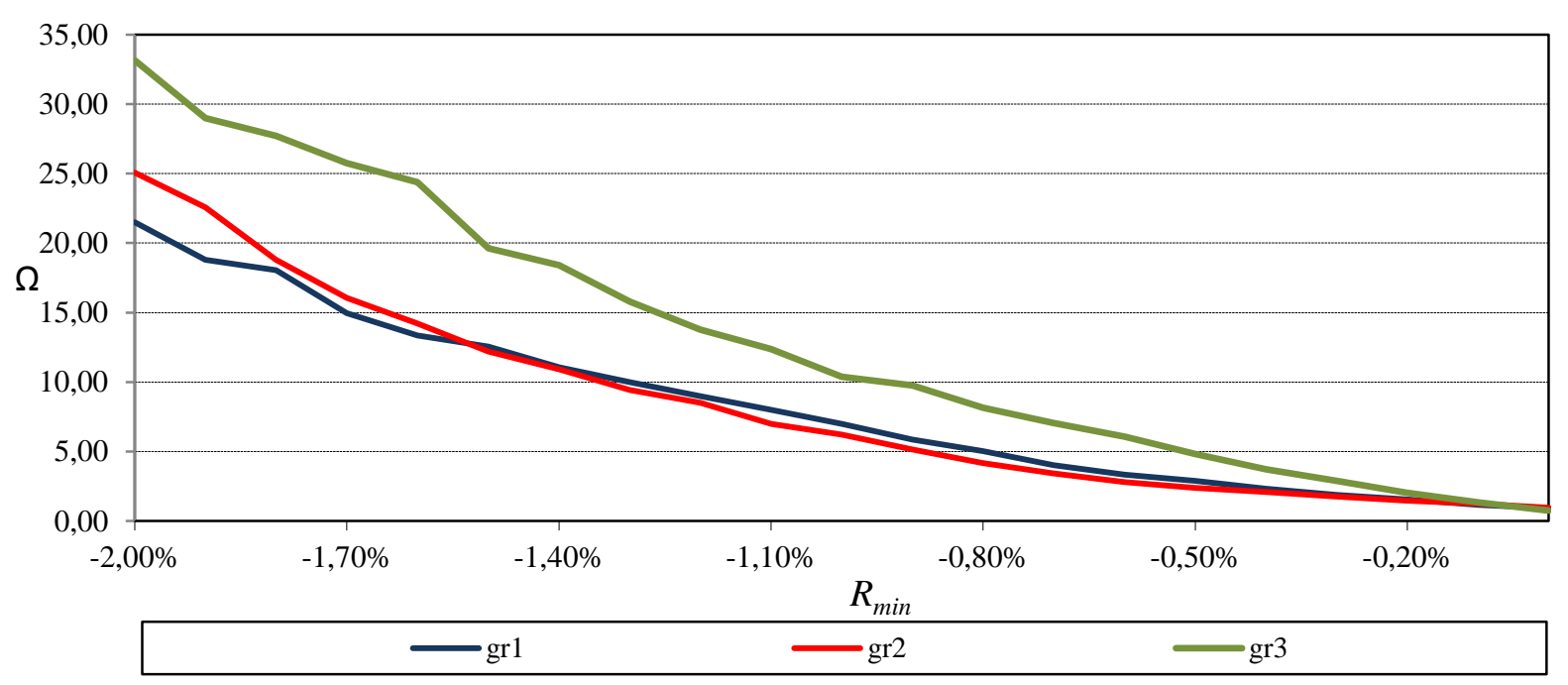

Portfolios D - Sensitivity of the Omega results in relation to $R_{\min } \in[0 \%,+2 \%]$

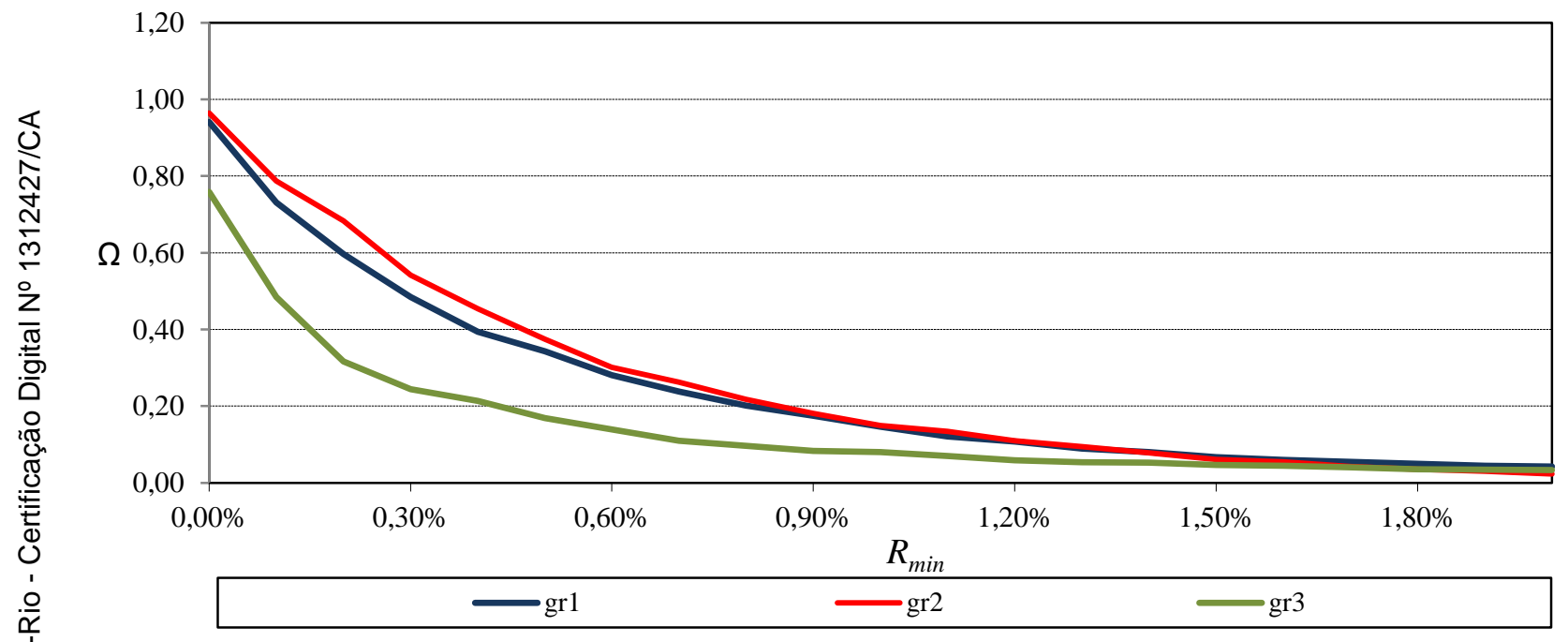

